\author{
Universidade de São Paulo \\ Faculdade de Economia, Administração e Contabilidade \\ DEPARTAMENTO DE ECONOMIA \\ Programa de Pós-graduação em Economia
}

INTERVENÇÕES DO ESTADO SOBRE O MERCADO BANCÁRIO E OS

TRADE-OFFS ENTRE EFICIÊNCIA, RESILIÊNCIA FINANCEIRA E ESTABILIDADE MACROECONÔMICA

Sílvio Michael de Azevedo Costa

Orientador: Prof. Dr. Márcio Issao Nakane

São Paulo

2011 
Prof. Dr. João Grandino Rodas

Reitor da Universidade de São Paulo

Prof. Dr. Reinaldo Guerreiro

Diretor da Faculdade de Economia, Administração e Contabilidade

Prof. Dr. Denisard Cnéio de Oliveira Alves

Chefe do Departamento de Economia

Prof. Dr. Dante Mendes Aldrighi

Coordenador do Programa de Pós-Graduação em Economia 
Sílvio Michael de Azevedo Costa

\section{INTERVENÇÕES DO ESTADO SOBRE O MERCADO BANCÁRIO E OS TRADE-OFFS ENTRE EFICIÊNCIA, RESILIÊNCIA FINANCEIRA E ESTABILIDADE MACROECONÔMICA}

Tese apresentada ao Departamento de Economia da Faculdade de Economia, Administração e Contabilidade da Universidade de São Paulocomo requisito para obtenção do título de Doutor em Economia.

Orientador: Prof. Dr. Márcio Issao Nakane

Versão Corrigida

(versão original disponível na unidade que aloja o programa)

São Paulo 
FICHA CATALOGRÁFICA

Elaborada pela Seção de Processamento Técnico do SBD/FEA/USP

Costa, Silvio Michael de Azevedo

Intervenções do estado sobre o mercado bancário e os trade-offs

entre eficiência, resiliência financeira e estabilidade macroeconômica /

Silvio Michael de Azevedo Costa. - São Paulo, 2011.

$260 \mathrm{p}$.

Tese (Doutorado) - Universidade de São Paulo, 2011.

Orientador : Márcio Issao Nakane.

1. Macroeconomia 2. Política monetária 3. Crédito 4. Bancos I. Universidade de São Paulo. Faculdade de Economia, Administração e Contabilidade. II. Título.

$\mathrm{CDD}-339$ 
Aos meus pais, André e Glória, e aо meu querido irmão, Romero. 
O trabalho acadêmico nunca é uma conquista individual. Muitas pessoas se importam com o resultado e pessoas especiais se preocupam também com o processo difícil, longo, desalentador às vezes, mas que parece inexorável aos que escolhem dedicar parte de suas vidas à pesquisa acadêmica. A todas as pessoas que me ofereceram carinho em algum momento, presto aqui o meu agradecimento. Em particular:

Ao professor Márcio Nakane, pelas diretrizes basilares da pesquisa, pelos conselhos, críticas e sugestões, sempre com sabedoria, nitidez e muita paciência. Agradeço a compreensão e o apoio. Obrigado pela orientação acessível e essencial para esta tese.

Aos excelentes professores que a Faculdade de Economia me ofereceu, com efeitos reais e persistentes para toda a vida. Manifesto minha gratidão ao professor Mauro Rodrigues pelos muitos ensinamentos, pelas intervenções na banca de qualificação e principalmente por mostrar como coisas aparentemente difíceis podem se tornar óbvias; ao professor Fábio Kanczuk, agradeço as valiosas sugestões e críticas da banca de qualificação; ao professor Pedro Duarte, agradeço pelas dicas especiais e pelo apoio ao projeto; e ao professor Eduardo Haddad, pelas oportunidades de aprender, pelos conselhos acadêmicos e, claro, pelas partidas de squash.

Aos professores André Minella e Leonardo Alencar agradeço muito o interesse na tese e a participação ativa durante a defesa, trazendo-me questões pertinentes e sugestões construtivas para melhorar os resultados e motivação adicional para o desenvolvimento da pesquisa.

Aos colegas da USP, sou grato pela convivência durante esses meses, pela colaboração e pelos os comentários sobre a pesquisa; em especial à Ana Barufi, Guilherme Attuy e Fernando Genta, obrigado pelo suporte e pelas conversas agradáveis.

Ao Banco Central do Brasil, pelo suporte financeiro e logístico essenciais ao desenvolvimento da pesquisa. Ao meu orientador técnico no Banco Central, Cláudio Jaloretto, pelo apoio antes e durante a pesquisa.

Ao amigo Paulo, pela opinião qualificada e pelo apoio contínuo; aos caros amigos Fernando, Shênia, Hélder e Maristela, pela preocupação e compreensão; aos amigos Rafael, Leonardo, Nilce, Flávio, Gustavo, Roger e Marcelo, Mônica, Fernandinha e Carol, muito obrigado por terem contribuído para a minha sanidade mental.

Aos meus pais, André e Glória, pela compreensão e paciência com um filho ausente, pelo incentivo incondicional e por sofrerem junto comigo, inocentes, até o último prazo. São os meus melhores exemplos de caráter, honra, dignidade e perseverança.

Ao meu irmão, Romero, obrigado por me atrapalhar várias vezes durante os estudos, sempre de forma precisa, quando uma pausa era necessária. 
Finis coronat opus 


\section{RESUMO}

A tese tem como propósito conectar os objetivos de eficiência da indústria bancária, resiliência financeira e estabilidade macroeconômica em um arcabouço integrado e multidimensional, para entender como as fricções financeiras geram trade-offs e como políticas de intervenção do Estado, baseadas em cada uma das dimensões, interagem com os demais conceitos. É desenvolvido um modelo DSGE de escala média que descreve explicitamente o setor bancário e inclui fricções no escopo da firma e da indústria bancária em adição às rigidezes tradicionais dessa classe de modelos. Os objetivos são interpretados a partir de relações endógenas do modelo. Exercícios de comparação de estado estacionário e simulação dinâmica estocástica de ajustamento a choque contracionista de política monetária são utilizados para entender a interação conceitual. Os resultados mostram que as fricções financeiras implicam pass-through imperfeito da política monetária porque o ajustamento dentro da estrutura do passivo bancário é diferente, implicando novas condições de resiliência financeira e induzindo ganhos de eficiência tecnológica. As intervenções do Estado analisadas são as barreiras à entrada, os recolhimentos compulsórios de reservas e os requerimentos de capital. Cada política baseada em um conceito específico de intervenção modifica de maneira particular o comportamento ótimo dos bancos, com efeitos sobre os conceitos adjacentes. As consequências da pesquisa estão relacionadas à formatação de políticas coordenadas e eficazes de intervenção e indicam uma nova fronteira de estudo de políticas ótimas no escopo da Economia Bancária.

Palavras-chave: Política Monetária, Canais de Transmissão, Banking, Resiliência Financeira 


\begin{abstract}
The purpose of this dissertation is to connect three banking-related concepts which are banking efficiency, financial resilience, and macroeconomic stability in a single integrated framework. It tries to understand how financial frictions settle trade-offs, whose nature and importance are investigated, and how institutional single-concept-based policies could generate untoward effects. A canonical medium-scale DSGE model is constructed featuring several banking frictions in addition to traditional real and nominal rigidities embodied in macro-models. Concepts are measured and interpreted in terms of endogenous metrics. Steady state comparisons and dynamic simulations for tighten monetary policy are performed. Results show that the concepts considered have very interesting linkages in the banking sector. Financial frictions induce an imperfect pass-through of monetary policy weather adjustments of deposits and bank capital are quite different. Changings in bank allocations and prices lead to new financial resilience conditions and efficiency gains. Institutional interventions such as barriers to entry, compulsory deposit rules and capital requirements, could impose very particular changes in bank's choices whose effects would spill over all the concepts. Findings lead to important issues for policy makers regarding the effectiveness and absent coordination of interventions for banking sector. Furthermore, results address a new research area of optimal policy in a multidimensional perspective.
\end{abstract}

Keywords: monetary policy, channels of monetary transmission, banking, financial stability. 


\section{SUMÁRIO}

LISTA DE FIGURAS

LISTA DE TABELAS

$\begin{array}{ll}\text { INTRODUÇÃO } & 7\end{array}$

1 EFICIÊNCIA BANCÁRIA, ESTABILIDADE MACROECONÔMICA E RESILIÊNCIA FINANCEIRA 17

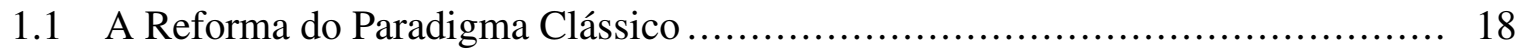

1.2 A Nova Teoria de Banking ............................................... 21

1.3 A Convergência em Economia Bancária: Trade-offs Micro-Macro ................. 24

1.3.1 Eficiência Microeconômica e Estabilidade Macroeconômica .............. 25

1.3.2 Estabilidade Macroeconômica e Fricções Financeiras ..................... 30

1.3.3 Eficiência Microeconômica e Resiliência Financeira...................... 33

1.4 A Evolução Técnica em Modelagem e Estimação............................... 37

1.5 Em Busca de uma Teoria para Bancos e Ciclos de Negócios ...................... 40

2 O MODELO DSGE COM FRICÇÕES BANCÁRIAS 45

2.1 O Modelo da Nova Síntese Neoclássica com Fricções Financeiras ............... 47

2.1.1 Famílias ............................................................. 48

2.1.2 Firmas .............................................................. 52

2.1.3 Produtores de Capital ................................................. 56

2.1.4 Empreendedores ..................................................... 58

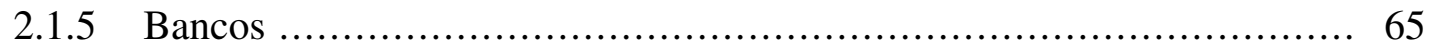

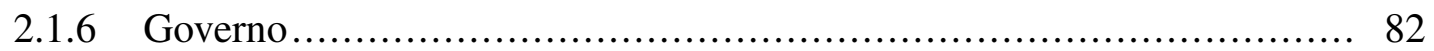

2.2 Conceitos e Medidas ...................................................... 84 


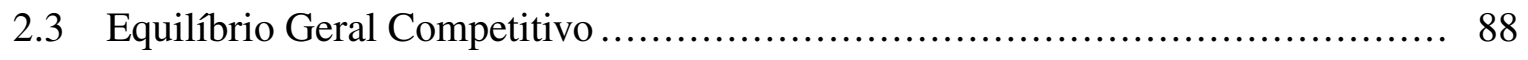

2.3.1 Formas Funcionais ............................................... 88

2.3.2 Definição do Equilíbrio .............................................. 90

2.3.3 Equilíbrio Geral Competitivo de Estado Estacionário .................... 92

2.3.4 Calibração ........................................................... 95

2.4 Resultados ...................................................................... 100

2.4.1 Propriedades Estáticas................................................. 101

2.4.2 Propriedades Dinâmicas .................................................. 107

3 OS TRADE-OFFS NAS INTERVENÇÕES SOBRE O MERCADO BANCÁRIO 129

3.1 Charter Value ................................................................ 131

3.1.1 Estática Comparativa ...................................................... 133

3.1.2 Dinâmica de Ajustamento .............................................. 137

3.2 Recolhimentos Compulsórios de Reservas ...................................... 143

3.2.1 Estática comparativa ................................................. 152

3.2.2 Dinâmica de Ajustamento ................................................. 155

3.3 Requerimentos de Capital ................................................... 160

3.3.1 Estática Comparativa ................................................. 162

3.3.2 Dinâmica de Ajustamento ............................................ 164

4 CONSIDERAÇÕES FINAIS 175

$\begin{array}{ll}\text { REFERÊNCIAS BIBLIOGRÁFICAS } & 188\end{array}$

$\begin{array}{lr}\text { APÊNDICES } & 189\end{array}$

A MODELO COM FRICÇÕES FINANCEIRAS 191

B SOLUÇÃO DO MODELO DSGE

C EXTENSÕES DO MODELO BÁSICO 


\section{LISTA DE FIGURAS}

2.1 Estática comparativa - Taxa de juros dos títulos públicos

2.2 Respostas ótimas da economia a choque contracionista de política monetária.

2.3 Respostas ótimas da economia a choque contracionista de política monetária indicadores conceituais

2.4 Respostas ótimas da economia a choque na produtividade total de fatores

2.5 Respostas ótimas da economia a choque na produtividade total de fatores - indicadores conceituais

3.1 Estática comparativa de economias com valores diferentes de Charter Value bancário.

3.2 Respostas ótimas a choque contracionista de política monetária para economias com diferentes valores de Charter Value....

3.3 Respostas ótimas a choque contracionista de política monetária para economias com diferentes valores de Charter Value- indicadores conceituais

3.4 Determinação da demanda por moeda do banco sob política de reservas compulsórias

3.5 Determinação da demanda por depósitos bancários sob política de reservas compulsórias .... 
3.6 Espaço de parâmetros e determinação da demanda por depósitos bancários

3.7 Determinação da oferta de crédito banco sob política de reservas compulsórias em títulos públicos

3.8 Estática comparativa de economias com valores diferentes de recolhimentos compulsórios em moeda

3.9 Respostas ótimas a choque contracionista de política monetária para economias com diferentes valores de recolhimentos compulsórios em moeda

3.10 Respostas ótimas a choque contracionista de política monetária para economias com diferentes valores de recolhimentos compulsórios em moeda - indicadores conceituais.

3.11 Estática comparativa de economias com alíquotas diferentes de requerimentos de capital bancário.

3.12 Respostas ótimas a choque contracionista de política monetária para economias com alíquotas diferentes de requerimento de capital bancário

3.13 Respostas ótimas a choque contracionista de política monetária para economias com alíquotas diferentes de requerimento de capital bancário - indicadores conceituais 


\section{LISTA DE TABELAS}

2.1 Calibração de Parâmetros

2.2 Relações de Estado Estacionário.

B.1 Todos os Resultados de Estado Estacionário

B.2 Momentos teóricos

B.3 Decomposição da Variância dos Choques (em \%), após 30 períodos 234

B.4 Coeficientes de Autocorrelação 


\section{INTRODUÇÃO}

008 E 2009 FORAM ANOS MARCADOS POR CRISES nas principais economias do mundo.

Os efeitos sobre a economia real foram intensos e ainda são notados: houve contração do produto e desemprego crescente nas principais economias desenvolvidas, como mostram os dados mais recentes ${ }^{1}$. A turbulência financeira nasceu no mercado norte-americano de ativos e a fragilidade financeira do sistema bancário - inicialmente explicada pela falta de confiança sobre a qualidade dos ativos dos bancos - definiu uma perspectiva de retração generalizada e mundial do crédito para os setores produtivos. A interligação financeira internacional desempenhou um papel central na contaminação, embora se ressalve que, dada a importância da economia americana, os distúrbios transbordariam de qualquer forma.

A crise surgiu em um sistema financeiro competitivo e desregulado de grandes restrições do Estado, justamente tais reconhecidas características que antes explicavam a eficiência e a estabilidade do sistema. Mesmo os resultados empíricos de comparação financeira entre os países², que sempre trouxeram poucos esclarecimentos e recomendações, apontavam como conclusão sobressalente que a maior estabilidade financeira está associada a políticas em favor do livre mercado. A defesa de uma regulação menos incisiva, cujo propósito seria apenas gerar incentivos à competição de mercado, era dominante na literatura de banking até então ${ }^{3}$. A ideia dominante era que, qualquer que seja seu objetivo, o regulador deve escolher políticas ade-

\footnotetext{
${ }^{1}$ IMF World Economy Outlook, http://www.imf.org.

${ }^{2}$ Barth, Caprio \& Levine (2000), Barth, Caprio \& Levine (2001), Barth, Caprio \& Levine (2002), Barth, Caprio $\&$ Levine (2005).

${ }^{3}$ Barth, Caprio Jr. \& Levine (2006), por exemplo.
} 
quadas às características das firmas e da indústria. Políticas de regulação por incentivos são naturalmente mais adequadas porque produzem reações endógenas às assimetrias informacionais e levam em conta a capacidade limitada de observação do regulador sobre os riscos do banco.

Alinhado a países onde a intervenção do Estado é mais vigorosa, o Brasil conta outra história financeira. $\mathrm{O}$ país priorizou a estabilidade do mercado em relação à competição mediante reformas promotoras da concentração bancária, nos anos finais da década de 1990, quando, por incitação do Estado, fusões e aquisições reorganizaram o mercado financeiro nacional. A implementação brasileira seguiu o conceito alemão de bancos múltiplos, que operam simultaneamente em diversos mercados de ativos. Hoje seis grandes bancos são responsáveis por $80 \%$ das operações totais de crédito e dominam o grande varejo, de acordo com dados do Banco Central do Brasil ${ }^{4}$ e da Federação Brasileira de Bancos (FEBRABAN) ${ }^{5}$. Os vários bancos menores atuam prioritariamente no crédito específico a micro e pequenas empresas ou em segmentos específicos de crédito ao consumo, como o crédito consignado. Os bancos públicos brasileiros são participantes destacados do mercado e também o BNDES (Banco Nacional de Desenvolvimento Econômico e Social) - uma peculiaridade brasileira - tem papel ativo na concessão de crédito de longo prazo a taxas de juros subsidiadas para grandes e médias empresas. Regulamentado sob os princípios de Basileia e mantendo uma indústria bancária concentrada, o Brasil realizou o ajustamento necessário à crise financeira de maneira menos traumática do que experimentaram as economias financeiramente desenvolvidas.

A observação da crise financeira mundial de 2008 trouxe alguns elementos interessantes para instigar a discussão teórica e prática sobre os mercados financeiros. A atuação dos países no saneamento dos seus mercados nacionais foi um fato proeminente da crise. Meses após a ajuda financeira implementada pelo governos aos bancos, notou-se a recuperação em diversos financeiros. Durante o processo, entretanto, as autoridades monetárias perceberam dificuldades

\footnotetext{
${ }^{4}$ http://www.bcb.gov.br/

${ }^{5}$ http://www.febraban.com.br/
} 
em lidar com a recessão econômica utilizando políticas de juros e então variados instrumentos alternativos para resgatar o sistema financeiro foram empregados. A recuperação organizada pelos governos veio acompanhada de críticas contundentes ${ }^{6}$ sobre os efeitos dinâmicos dessa atitude, amparadas pelos desincentivos à boa conduta financeira em um sistema já sujeito a relevantes preocupações de moral hazard.

Outro fato importante foi a inação dos organismos normativos internacionais diante da extensão e da amplitude da fissura econômica. Antes, tais instituições atuavam na definição e recomendação de regras de conduta na operação dos mercados. A implementação de um sistema internacional de regras prudenciais, portanto, não se mostrou efetiva de propósito e a falha de regulamentação recriou a necessidade geral de discutir novos termos políticos e econômicos sobre regras prudenciais, eficiência dos mercados e participação do Estado na operação dos sistemas financeiros.

Está latente na prática econômica, portanto, a interação entre estabilidade financeira e estrutura dos mercados bancários. Também se colocam, com frequência, outras questões práticas relativas à atuação efetiva da política monetária nos momentos em que o crédito está comprimido ou mesmo sua influência na intensificação das crises. No contexto do mercado bancário, são duas coisas diferentes: i) a estrutura do mercado bancário e as relações entre essas firmas que conectam estabilidade e eficiência; e ii) as intervenções do Estado que têm o objetivo de alterar o comportamento dos bancos e promover a estabilidade do sistema. O âmago do problema está na potencial miopia que a ação de uma intervenção particular qualquer do Estado, servindo a determinado objetivo, produz sobre outros objetivos também relevantes, transmitidos pelo comportamento das firmas bancárias.

São três os objetivos essenciais ${ }^{7}$ trabalhados na estrutura e nas intervenções sobre o mercado

\footnotetext{
${ }^{6} \mathrm{O}$ argumento de que políticas públicas equivocadas podem piorar o ajustamento de economias em crise ou mesmo até causar crises não é recente. Friedman \& Schwartz (1963) analisaram esse fato com dados descritivos para a economia americana e reforçaram o argumento.

${ }^{7}$ Cada objetivo citado tem sido objeto de estudo particular de um campo de pesquisa econômica. A literatura teórica e empírica em cada área permite interpretar um objetivo como um conceito próprio ao qual está adjacente a noção de bem-estar e de política ótima. Assumindo a simplificação do termo, a tese utiliza também o termo
} 
bancário: i) eficiência competitiva da indústria; ii) resiliência financeira; e iii) estabilidade Macroeconômica. Entende-se por resiliência financeira a capacidade de os bancos se ajustarem a crises financeiras sem rompimento da estrutura sistêmica e retornarem à normalidade econômica no médio prazo.

A pergunta da tese é como analisar as interações entre os objetivos de eficiência microeconômica, resiliência financeira e estabilidade macroeconômica em um arcabouço de equilíbrio geral dinâmico e como as políticas de intervenção do Estado, localizadas em uma dessas dimensões, alteram o comportamento ótimo dos bancos e extravasam para os objetivos/conceitos subjacentes.

O propósito da tese é ressaltar a interface entre os três objetivos/conceitos econômicos quando da elaboração de políticas econômicas, qualificando a discussão pela análise simultaneamente generalista e analítica da economia bancária, no sentido em que a abordagem requer a simplificação das particularidades setoriais, por exemplo, para viabilizar a análise em outras dimensões, como estabilidade financeira e macroeconômica, ao mesmo tempo em que são utilizados métodos atuais de exploração matemática e econométrica para analisar o problema proposto.

Respostas teóricas e empíricas às perguntas da tese são urgentes. A necessidade é melhor reconhecida hoje pela evidência que a crise trouxe ao sistema financeiro, mas são questões ainda em aberto na pesquisa econômica. As discussões atuais envolvem a constituição de mecanismos que evitem o surgimento e a propagação de choques financeiros, no escopo de mais regulação prudencial recomendada pelos organismos internacionais. No caso brasileiro ${ }^{8}$,

\footnotetext{
“conceito" quando se refere a tais objetivos, posicionando-se adjacente aos estudos especializados de cada área.

${ }^{8}$ A Lei 4595 de 1964, que criou o Conselho Monetário Nacional, o Banco Central do Brasil e estruturou todo o Sistema Financeiro Nacional (SFN), determina ipsis litteris em seu artigo 18, parágrafo segundo, que "O Banco Central do Brasil, no exercício da fiscalização que lhe compete, regulará as condições de concorrência entre instituições financeiras, coibindo-lhes os abusos com a aplicação da pena nos termos desta lei". Todavia a Lei 8884 de 1994 regulamenta o Conselho Administrativo de Defesa da Concorrência (CADE) como órgão de defesa da concorrência para quaisquer diligências, sem exceção, o que configura contradição com a legislação anterior. O Banco Central está constituído como autarquia federal sob o Ministério da Fazenda, enquanto o CADE é uma autarquia vinculada ao Ministério da Justiça. $\mathrm{O}$ arcabouço legal brasileiro específico possui pendências na clareza sobre as atribuições compartilhadas e exclusivas de Banco Central e CADE, acerca da determinação de regras de concorrência no setor bancário, muito embora o parecer da Advocacia Geral da União (AGU), número LA-01 de 2001, determine a competência exclusiva do Banco Central em casos de propostas que envolvam risco sistêmico.
} 
as respostas da tese pode encaminhar outras dimensões na análise técnica, tornando-a mais ampla e integrada, em assuntos relacionados a reformas no conjunto institucional, como as já se encaminham no Poder Legislativo brasileiro9 .

Descrever o que seria eficiência da intervenção do Estado em um contexto ampliado de Regulação Econômica como o que se propõe na tese é algo que imediatamente ocorre, mas é substancialmente complexo nas condições técnicas do momento. Todavia, antes de encaminhar qualquer proposta nesse sentido, a pesquisa precisa avançar no sentido de entender a natureza das interações de objetivos que acontecem na indústria bancária e identificar os trade-offs.

No escopo desta tese, as restrições impostas pelo governo ao funcionamento livre dos mercados são chamadas genericamente de intervenções de Estado, ou regulação do Estado. O termo regulação é definido de forma ampla como sendo a utilização do poder legal coercitivo do Estado sob o domínio econômico, com o intuito de restringir as decisões livres dos agentes para alcançar um propósito específico. Propõe-se classificar as intervenções em três categorias, consistentes com os objetivos apontados: i) regulação técnica, que engloba as questões de defesa da concorrência, organização da indústria e questões técnicas do produto; ii) regulação prudencial, que tem por meta gerenciar risco sistêmico, evitar corridas bancárias e seus custos e garantir estabilidade financeira; e iii) intervenções macroeconômicas, ou de política econômica, cujo propósito é fazer estabilidade do produto, controle de inflação e do desemprego. O objetivo da regulação econômica é a eficiência alocativa do mercado para uma dada estrutura de competição. Por sua vez, o objetivo da regulação prudencial é a resiliência financeira, a capacidade de o país manter um ambiente de negócios dinâmico com seguridade. As intervenções de política econômica têm o propósito de controle de flutuações de produto e preços e de crescimento econômico. Sob essa perspectiva ampla, chamamos Regulação Econômica o

Impotentes diante da confusão legal, Banco Central e CADE dividem a responsabilidade pela análise e resolução sobre aspectos concorrenciais do SFN.

${ }^{9}$ O Projeto de Lei Complementar 344/2002 da Câmara dos Deputados, apresentado pelo Poder Executivo e com prioridade de trânsito, pretende conceder autoridade decisória principal ao Banco Central para analisar diligências sobre quaisquer reestruturações do mercado bancário, como fusões e aquisições, sempre que envolvam questões de confiabilidade e segurança sistêmicas. 
conjunto daquelas três categorias.

Os três objetivos diferentes de regulação sobre o setor bancário e suas interações não são objetos de estudo inéditos. Os resultados da literatura especializada, como serão adiante detalhados, já sugerem trade-offs. Isso significa que as ações do Estado e seus resultados até podem ser efetivos no objetivo a que inicialmente são propostos - talvez nem isso - mas podem ser indesejáveis sob uma outra perspectiva. A tese pretende posicionar os conceitos em um ambiente econômico com descrição detalhada da intermediação financeira de tal forma que permita resgatar as conexões que se projetam quando do funcionamento do mercado bancário.

Esta monografia apresentará a construção de um modelo de equilíbrio geral dinâmico e estocástico (DSGE - Dynamic Stochastic General Equilibrium) de escala média, com a identificação explícita do banco e da estrutura do mercado bancário, sob o qual serão incluídas fricções nominais e reais de origem econômica e financeira. $\mathrm{O}$ foco do trabalho é a descrição do banco e do mercado bancário como elementos centrais do macro-modelo de escala média, no qual são detalhados os relacionamentos daquelas firmas com os demais agentes mediante a celebração de contratos financeiros de crédito. Nesse arcabouço, serão ainda analisados três instrumentos tradicionais de intervenções do Estado, que estão motivados em cada um dos conceitos: a inclusão de barreiras a entrada na indústria; a determinação de recolhimentos compulsórios de reservas bancárias junto ao banqueiro central; e a imposição de requerimentos mínimos de capital para a operação dos bancos.

Esta tese é o primeiro estudo que traz os três conceitos/objetivos reunidos em um modelo único do tipo DSGE. As principais contribuições da pesquisa são i) a aproximação dos conceitos de eficiência, resiliência financeira e estabilidade macroeconômica no contexto da firma bancária; ii) a modelagem de firmas bancárias e suas fricções em uma escala inédita nos modelos DSGE; iii) a construção de variáveis endógenas que são utilizadas como indicadores para avaliar a dinâmica do sistema em termos dos conceitos propostos; e iv) a generalização do problema de intervenções sobre o mercado bancário. 
Modelos macroeconômicos estão motivados em sua maioria na análise de fenômenos agregados - como estabilização de preços, efeitos reais de política monetária e crescimento econômico - e construídos com o objetivo de esclarecê-los. A abordagem aqui empregada é sutilmente diferente e não compartilha o mesmo objetivo de explicar esses fenômenos. A metodologia de equilíbrio geral walrasiano dinâmico e estocástico utilizada na macroeconomia pode receber outras contribuições de modelagem da microeconomia com o objetivo de investigar assuntos relacionados à ligação micro-macro. Isso é fato atual e os modelos mais recentes fazem uso de desagregação necessária para incluir fricções que interessam ao resultado macro. As técnicas são muito utilizadas na academia e nos bancos centrais e reconhecidas pela capacidade de descrever a oferta e a demanda de todos os mercados relevantes com base em microfundamentos e considerando expectativas racionais dos agentes econômicos. Nesse ponto há apenas a diferença de aplicação do método: não apenas o resultado macro é importante, mas os efeitos sobre a estrutura de mercado, sobre os contratos financeiros e sobre a oferta do banco estão em análise. A análise têm duas vias: resultados macro e microeconômicos interagem simultaneamente e os conceitos apresentados são interpretados por medidas do modelo. O framework resultante está sintonizado com os avanços recentes em termos de explicação macroeconômica ${ }^{10}$ e contém uma descrição nítida e relevante para as firmas bancárias, suas fricções e sua organização industrial.

Em relação à literatura, a monografia posiciona-se como um trabalho da Nova Síntese Neoclássica $^{11}$ e contribui com a literatura macroeconômica interessada no estudo de fricções financeiras

\footnotetext{
${ }^{10}$ Por seguir o arcabouço tradicional de modelos DSGE, os resultados macroeconômicos guardam aderência com aqueles obtidos por Christiano, Eichenbaum \& Evans (2005), Smets \& Wouters (2003), Schmitt-Grohé \& Uribe (2005), por exemplo.

${ }^{11} \mathrm{~A}$ incorporação de fricções em modelos macroeconômicos da família neoclássica tem sido novidade teórica nos estudos sobre política monetária. Essa família de modelos tem sido denominada por Nova Síntese Neoclássica (NNS). Goodfriend \& King (1998) definem a nova área como a convergência entre agendas de pesquisa de neoclássicos e neokeynesianos, na qual os objetivos fundamentais são a análise econômica aplicada de políticas macro, a crença em que rigidez de preços de curto prazo é fundamental para explicar flutuações econômicas e o compromisso metodológico de alinhamento microeconômico com o paradigma de otimização de agentes racionais. Os estudos da nova área têm o compromisso de atender as hipóteses de expectativas racionais e maximização intertemporal dos agentes, os programas keynesianos para a demanda agregada na determinação de preços e produto e as explicações da oferta agregada proposta pela teoria de real business cycles. O resultado central que une teorias outrora divergentes é a obtenção de maior aderência entre os resultados apontados por modelos teóricos estruturais e as evidências empíricas.
} 
em um contexto agregado, mas com preocupação em descrever de forma rigorosa o papel dos bancos na economia. A escolha de um modelo macroeconômico com características tão flexíveis para incorporar desenhos microeconômicos torna-se natural pela natureza do problema da tese, uma vez que intervenções sobre o setor bancário têm como propósitos, mecanismos e consequências tanto macroeconômicos quanto microeconômicos. O paradigma de equilíbrio geral walrasiano enquanto tecnologia de modelagem para permitir superar, ainda que parcialmente, a Crítica de Lucas Jr. (1976) ${ }^{12}$.

Esta tese conversa também com a crescente e atual literatura macroeconômica interessada em analisar efeitos reais de política monetária e o papel de fricções reais e nominais coletadas da Teoria dos Ciclos Reais de Negócios e da Teoria Novo Keynesiana ${ }^{13}$. Os textos mais recentes ${ }^{14}$ nesse campo buscam entender também o papel das fricções financeiras na produção de dinâmicas alternativas e que melhor expliquem fenômenos econômicos.

A tese tem caráter principalmente investigativo e, em uma dimensão restrita, também propositivo. A investigação que se promove é a existência de um problema de coordenação do Estado nas intervenções sobre o setor bancário e que pode, em tese, constituir-se em um inédito problema quantitativamente relevante, com efeitos sobre a atividade econômica, a estabilidade financeira e a eficiência setorial. A tese é propositiva na forma como encaminha as questões e faz uso da metodologia disponível, além de como extrai conclusões que interligam objetivos antes desconectados. As conclusões da tese reforçam as preocupações sobre a estrutura não coordenada de regulação dos mercados financeiros. Os resultados levantam necessidades internas do sistema financeiro que, preliminarmente, apenas indicam direções para formatação de políticas públicas. Evidentemente podem fornecer subsídios para discutir os papéis do Estado e do mercado bancário e os graus de intervenção dos governos sobre o sistema financeiro, o que é um assunto pertinente, contextualizado e responsável no propósito de discutir alterações na

\footnotetext{
${ }^{12}$ No capítulo 1 esse argumento é adequadamente discutido.

${ }^{13}$ Diamond \& Rajan (2006), Christiano, Motto \& Rostagno (2007), Iacoviello (2008), Christensen et al. (2007), por exemplo.

${ }^{14}$ Goodfriend \& McCallum (2007), Gerali et al. (2010), dentre tantos.
} 
estrutura de regulação. Contudo, a construção de políticas públicas não faz parte do escopo da tese. Antes seria essencial definir a política ótima de intervenção sobre a economia bancária no contexto proposto, assunto complexo que transborda as fronteiras e restrições desta pesquisa de doutorado.

A tese será desenvolvida em quatro capítulos. O capítulo primeiro traz uma análise comentada da literatura teórica e empírica relacionada ao programa da pesquisa, destacando as conexões entre banking, fragilidade financeira e canais de transmissão monetária. A revisão permite situar adequadamente esta tese na produção acadêmica em Economia dos diferentes campos de estudo diretamente relacionados com o problema e os resultados da pesquisa.

O segundo capítulo apresenta o framework teórico básico. O modelo contempla a inclusão de rigidezes nominais e reais tradicionais nos trabalhos da Nova Síntese Neoclássica, como a persistência dos hábitos de consumo, rigidez de preços do bem final e custos de ajustamento sobre o investimento. O detalhamento da firma bancária contempla i) mercados de crédito; ii) acelerador financeiro seguindo Bernanke, Gertler \& Gilchrist (1999); e iii) fricções financeiras, como a restrição de liquidez de um sistema de pagamentos de liquidação bruta em tempo real, redesconto, capital próprio do banco e tecnologia de produção de crédito. A estrutura da indústria bancária é a competição monopolística. Desenvolve-se uma análise da oferta do banco e como as fricções financeiras afetam o contrato financeiro. Após a apresentação do modelo e a caracterização dos equilíbrios parciais e do equilíbrio geral dinâmico e estocástico, os conceitos em observação tomam forma prática na interpretação de medidas endógenas ao próprio modelo. O capítulo segundo ainda define e resolve, por métodos numéricos e de aproximação, o equilíbrio geral da economia e analisa o estado estacionário e a dinâmica estocástica de ajustamento da economia ao instrumento de juros da política monetária.

O terceiro capítulo dá sequência à análise e usa o modelo como benchmark para analisar três instrumentos usuais de intervenção do Estado, cada um respondendo a um conceito de regulação: i) Charter Values interpretados como barreiras à contestabilidade da indústria, portanto relacionado à regulação técnica; ii) recolhimentos compulsórios de depósitos bancários, en- 
quanto instrumento tradicional auxiliar de política monetária; e iii) requerimentos de capital como instrumento da regulação prudencial. A análise econômica é desempenhada por i) estática comparativa dos equilíbrios de estado estacionário e ii) comparação de funções de resposta ao impulso monetário, para verificar padrões na dinâmica de transição, com vistas a entender o ajustamento macroeconômico e setorial.

Por fim, o capítulo quarto retoma a pergunta da tese, resume os resultados gerais, faz considerações finais sobre os estudos e também sugere evoluções para o modelo básico e outras linhas futuras de pesquisa. 


\section{Capítulo 1}

\section{EFICIÊNCIA BANCÁRIA, ESTABILIDADE MACROECONÔMICA E RESILIÊNCIA FINANCEIRA}

$\mathrm{P}$

OSICIONAR ESTA TESE na literatura econômica é o objetivo do capítulo. Não é algo simples, haja visto que o escopo de estudo interage com três áreas de conhecimento dentro da Economia e os muitos trabalhos teóricos e empíricos dessas áreas não se sintetizam em fatos econômicos estilizados, muito porque os sistemas financeiros dos países apresentam notável diversidade estrutural ${ }^{1}$.

A revisão da literatura empenhada a seguir motiva academicamente o tema da pesquisa e também justifica a pergunta desta tese. A análise da literatura específica mostra que as direções da pesquisa econômica já apresentam alguma congruência, apresentando análises de potenciais interconexões entre os conceitos estudados, embora não seja suficientes para responder à preocupação generalista da tese.

A organização deste capítulo apresenta per se um ponto de vista sobre a produção científica em Economia, em especial nas referências aos assuntos de que esta tese trata.

\footnotetext{
${ }^{1}$ Barth, Caprio \& Levine (2001)
} 


\subsection{A Reforma do Paradigma Clássico}

O setor financeiro das nações sempre despertou destacado interesse na pesquisa econômica. São as características especiais deste setor da economia - cite-se o gerenciamento intertemporal da liquidez de ativos diversos, as assimetrias de informação do contrato bancário de crédito e a estreita interface da oferta de crédito com investimento na produção de bens e consumo e poupança das famílias - que possivelmente justificam a fama temática. Paradoxalmente, a teoria clássica de mercados completos de Arrow-Debreu é clara e precisa ao concluir pela irrelevância da firma bancária no ambiente econômico: os mercados financeiros são absolutamente redundantes em modelagem porque atuam como simples intermediários entre poupadores e investidores.

Keynes (1936) já percebia que bancos eram instituições destacadas no arranjo econômico e caracterizou como função dessas firmas especiais a tarefa de reavaliar a oferta de crédito que determina o investimento privado. Isso porque a decisão de liquidez dos bancos deve antecipar a realização do investimento em capital fixo. Embora tenha observado o papel crucial dos bancos na determinação do investimento, Keynes não se deteve na avaliação do comportamento das firmas bancárias.

Os trabalhos de Gurley \& Shaw (1955) são reconhecidamente os primeiros a tratar da intermediação financeira. Os autores todavia ainda entendiam os intermediários como agentes neutros. Para eles bancos apenas repassam recursos entre agentes econômicos. Fama (1980) também ressaltou em seus trabalhos o papel neutro da intermediação financeira. Para ele, "se os bancos respondem aos gostos e oportunidades dos demandantes e ofertantes de ativos de portfolio, eles são apenas intermediários e o papel de um setor bancário competitivo no equilíbrio geral é meramente passivo" (FAMA, 1980, p. 80).

James Tobin delineou, em notável artigo de 1963, duas vertentes conceituais exclusivas sobre a atividade de intermediação financeira e o papel dos bancos na economia. Chamou de "visão antiga" aquela concepção clássica na qual é irrelevante o comportamento dos bancos para 
determinar as condições de financiamento da economia. A visão defendida por Tobin (1963) entende que bancos comerciais criam moeda e podem atuar de forma estratégica e otimizadora, expandindo a oferta de crédito de acordo com suas oportunidades de negócios. Sob a nova perspectiva, os bancos são gestores de ativos financeiros diferentes em termos de liquidez.

É a visão nova que sustenta a pesquisa da área de Microeconomia Bancária e da moderna Macroeconomia que considera fricções financeiras. No programa da Microeconomia Bancária, o papel não neutro dos bancos para a economia pode ser incorporado mediante duas abordagens. A primeira trata da organização da indústria bancária, que entende o setor como fornecedor de serviços de liquidez aos clientes, em que a diferenciação dos produtos lidera questões como barreiras à entrada e competição monopolística. O outro modo está relacionado com a ideia de mercados incompletos. As assimetrias informacionais existentes entre as partes de um contrato de intermediação financeira ou mesmo entre controladores e acionistas são relevantes para explicar transações financeiras e um funcionamento do mercado diferente daquele prescrito por modelos da tradição Arrow-Debreu.

Por outro lado, os textos menos recentes de Macroeconomia não contém em termos de modelagem o papel não neutro da indústria de intermediação financeira na oferta de crédito da economia. Entretanto, cabe registrar que vários estudos tentam propor a conexão da economia real com fenômenos do mercado financeiro. Friedman \& Schwartz (1963), por exemplo, chamavam a atenção para o padrão de ciclos no produto americano estreitamente associado a crises no sistema financeiro. A fragilidade financeira e os ciclos econômicos são assuntos próximos.

Monetaristas como Friedman argumentavam da necessidade de observar também outros preços de ativos da Economia, ao invés de resumir a análise à taxa de juros, nas políticas de controle de moeda (FRIEDMAN, 1956). Indicavam, portanto, que interpretações adicionais sobre a transmissão de política monetária poderiam ser obtidas pela análise dos preços relativos entre diversos outros ativos da economia, além da dívida pública. Faz sentido, porque a forma de alocação da riqueza das famílias é determinante na explicação dos efeitos reais sobre a economia de políticas monetárias. Mishkin (1996) pondera que dois canais de transmissão de política 
monetária podem ter a identificação atribuída aos monetaristas: i) a teoria de investimento do "q" de Tobin; e ii) o efeito riqueza sobre o consumo.

O teorema de Modigliani \& Miller (1958) pode ser responsabilizado pela prevalência do canal tradicional de taxa de juros como mecanismo básico de transmissão monetária. $\mathrm{O}$ teorema da irrelevância proposto pelos autores explicava que o investimento de firmas não depende de sua estrutura de capital. Dessa forma, o papel do crédito e dos bancos é irrelevante na produção de efeitos reais.

A consolidação de um papel mais relevante para os bancos nas principais correntes da pesquisa econômica só aconteceu mesmo a partir da segunda metade do século XX, principalmente depois os avanços da Economia da Informação. A importância das fricções do mercado de crédito determinaram a mudança de paradigma na Microeconomia e restabeleceram a possibilidade de Modigliani \& Miller (1958) estarem errados. O detalhamento dos problemas de assimetria de informação e de custos de agência nos mercados financeiros permitiu questionar a irrelevância da estrutura na decisão de investimento. O potencial teórico que advém dos empréstimos bancários fez revigorar a conexão entre a nova Microeconomia Bancária e a Macroeconomia, no tocante aos mecanismos de transmissão.

A existência de fricções financeiras torna inválido o resultado de full risk-sharing obtido em economias do tipo Arrow-Debreu. A simplificação macroeconômica de ignorar essas fricções, ainda que aceitável em boa parte das situações, a julgar pelo objetivo da modelagem, pode definir resultados viesados se as hipóteses risk-sharing não estão atendidas. Freixas \& Rochet (2008, Cap. 6) ponderam que especialmente três áreas da Macroeconomia têm resultados afetados por imperfeições financeiras: RBC (Real Business Cycles), os canais de transmissão de política monetária e a fragilidade do sistema financeiro em coordenar o investimento da economia, com implicações sobre crescimento econômico. 


\subsection{A Nova Teoria de Banking}

A moderna teoria de banking tipifica as funções dos bancos em quatro categorias: i) oferecer serviços de pagamento, liquidação de títulos e troca de moedas; ii) transformar ativos de padrões, qualidades e maturidades diferentes; iii) gerenciar riscos, especialmente risco de crédito, risco de taxas de juros e risco de liquidez; e iv) processar informação e monitorar tomadores de empréstimos (FREIXAS; ROCHET, 2008, Cap. 1, p. 2). No exercício de suas atividades, os bancos comerciais criam moeda (TOBIN, 1963), alterando a oferta monetária da economia, quando fornecem crédito ao setor privado (famílias e firmas). A existência de crédito privado é elemento crucial para a obtenção de resultados de full risk-sharing entre agentes avessos a risco e de suavização intertemporal do consumo e do produto nacionais. Donde se conclui que as instituições financeiras não são irrelevantes, mas protagonistas no processo de alocação de recursos da economia, contradizendo Modigliani \& Miller (1958).

O modus operandi dos mercados financeiros tem implicações sobre as alocações de moeda, crédito e bens da economia, seja por questões de estrutura de mercado, seja por assimetrias informacionais no contrato financeiro. Por tal motivo, o sistema financeiro apresenta características propícias para receber intervenções do Estado, sob a motivação de regulação e supervisão. Em uma perspectiva de banking, Freixas \& Rochet (2008, Cap. 9) argumentam que a necessidade de existir um regulador central das atividades do sistema bancário leva em conta três objetivos: deter o monopólio da emissão de moeda, atuar sobre a fragilidade dos bancos e garantir proteção aos depositantes. A regulação econômica pode valer-se de muitos instrumentos tradicionais para atingir seus objetivos, por exemplo o controle de preços, quantidades ou qualidade da produção setorial ou mesmo atuar sobre a contestabilidade (entrada e saída de firmas) do mercado. Mas o regulador central dispõe também de instrumentos que são especiais ao setor bancário. Freixas \& Rochet (2008, p. 305) classificam esses instrumentos em pelo menos seis categorias: i) limites de bandas para juros sobre os depósitos; ii) restrições sobre entrada, ramificação, redes e fusão de bancos; iii) restrições de portfolio; iv) garantias sobre os depósitos; v) requerimentos de capital; e vi) monitoramento de mercado. Apesar da justificativa 
de atuação e da disponibilidade de instrumentos, os autores destacam possíveis distorções relacionadas à intervenção do Estado sobre o mercado bancário: i) a geração de riscos excessivos pelos administradores, solicitando mais regulação; ii) a regulação não extrai completamente o excedente de mercado, justificando assim a regulação por outros motivos além da proteção aos depositantes; iii) os custos regulatórios diretos e indiretos são elevados, criando rendas informacionais para os bancos; e iv) os reguladores podem ser capturados pela indústria bancária (FREIXAS; ROCHET, 1997).

As intervenções de Estado $^{2}$ estão inicialmente justificadas na ideia de melhorar a alocação de livre mercado de acordo com alguma medida de bem-estar. Por ser normativa em essência, a função objetivo do regulador pode ainda contemplar conceitos além da eficiência alocativa. A teoria tradicional propõe que o governo atue apenas para corrigir patologias de mercado ${ }^{3}$. Muitos estudos na área de banking tratam de mostrar falhas e fricções diversas do setor bancário e sob as quais se funda a justificativa para atuação do Estado ${ }^{4}$.

É a preocupação com a segurança financeira que tem destacado espaço na discussão atual. Evitar crises sistêmicas é o principal objetivo dos instrumentos de regulação prudencial, que toma forma mediante recomendação de órgãos diretivos internacionais. É pacífico que os custos sociais e as externalidades cross-border de crises financeiras sistêmicas são dispendiosos demais para a sociedade e, por isso, precisam ser adequadamente controlados pelos Estados. Sob tais

\footnotetext{
${ }^{2}$ A teoria econômica neoclássica do Estado é normativa em essência, porque formula como deveria ser o ambiente econômico e como a atuação do governo altera escolhas e ações seguindo critérios que contém juízos de valor. Em princípio, seria atribuição do Estado apenas a provisão de bens públicos em sentido estrito, como serviços de defesa e justiça. O Primeiro Teorema do Bem-Estar advoga que indivíduos auto-interessados, racionais e perfeitamente informados conseguem obter alocações econômicas eficientes no sentido de Pareto quando atuam em mercados perfeitamente competitivos. Portanto, o Estado não pode melhorar o resultado de mercados completos. Todavia, contribuições mais recentes dentro do paradigma neoclássico analisam a interferência do Estado em situações nas quais a operação competitiva não seja eficiente, por falha daqueles pressupostos, e nesse caso a atuação de um planejador central benevolente poderia garantir a eficiência alocativa.

${ }^{3}$ As tradicionais falhas de competição apontadas são as presenças de agentes com poder de mercado, de informação assimétrica e de externalidades de consumo ou produção. Ainda assim, regulação de bem-estar promovida pela intervenção exógena de governo não garante a certeza de acréscimos de eficiência, podendo mesmo ser preferível a não-interferência à regulação, ao menos em algumas situações particulares (DEMSETZ, 1968).

${ }^{4}$ Freixas \& Rochet (2008) e Degryse, Kim \& Ongena (2009) oferecem uma perspectiva ampla e complementar entre si da literatura de banking, tanto em aspectos teóricos quanto empíricos. Ambos têm a virtude de coletar artigos dispersos e apresentá-los de maneira organizada, fornecendo uma visão tão geral quando fundamentada de vários temas da área.
} 
argumentos, as regras internacionais de controle de capital delineadas no primeiro Acordo de Basileia, em 1988, surgiram com a intenção de ponderar os ativos pelos riscos envolvidos na produção financeira, com o objetivo de regular a alavancagem financeira para níveis considerados adequados à resiliência financeira.

Ancorada nas crises financeiras da década de 90, a revisão da proposta inicial concluiu com a publicação do Acordo de Basileia II, em 1999, que está em processo de implementação operacional no Brasil. Nessa versão, além dos riscos de mercado e de crédito, também são considerados na ponderação dos ativos os riscos operacionais das firmas do setor. Mesmo bem justificada durante as décadas passadas, a implementação é deficiente, todavia, porque as organizações internacionais apenas recomendam as regras prudenciais, cabendo a cada país a decisão de assinar e implementar o acordo em suas legislações nacionais. A implementação atual não se mostrou efetiva no seu propósito, uma vez que a interligação internacional dos mercados requer que todos os principais sistemas financeiros operem sob aquelas regras e assim não acontece, por exemplo, no sistema financeiro dos Estados Unidos da América, o mais ativo e importante do mundo. A atual crise financeira mundial traz sérios questionamentos sobre qual é a regulação prudencial adequada para garantir estabilidade ao sistema financeiro internacional. Não obstante, o BIS (Bank of International Settlements) divulgou ainda em 2010 regras novas para o capital mínimo requerido dos bancos, definindo Basileia III, com implementação prevista para 2013. A nova recomendação acrescenta controles de capital e critérios de avaliação de ativos mais rígidos, com o intuito de provocar reformas nas regras de prudência para a alavancagem e a liquidez de bancos nos países.

Entretanto observa-se no mercado bancário não apenas restrições cujo objetivo é corrigir falhas de competição de mercado, externalidades ou assimetrias informacionais, mas também há controles de natureza macroeconômica cujo propósito são a estabilidade do produto e do consumo e a garantia do investimento. São exemplos dessa atuação macro do Estado os tradicionais instrumentos de política monetária, como requerimento compulsório de reservas dos bancos junto ao banqueiro central, o empréstimo de última instância feito à autoridade monetária, também conhecido como redesconto, e a operação de títulos públicos. Todos esses instrumentos valem- 
se do sistema bancário para transmitir a firmas e famílias os sinais de contração e expansão da oferta de moeda. Ainda que se argumente que também em política fiscal existem instrumentos de atuação macro que trabalham fora do mercado bancário, a necessidade de coordenação no sentido de Sargent \& Wallace (1981) e Leeper (1991) explica porque as atividades de estabilização de preços e produto são tratadas essencialmente pelo conjunto de ferramentas de política monetária.

\subsection{A Convergência em Economia Bancária: Trade-offs Micro-Macro}

As flutuações são um fenômeno bastante estudado em teoria econômica. A literatura macro tem dedicado muitas páginas para entender porque surgem, como se alimentam e como recrudescem os ciclos, que não possuem frequência determinística, amplitude prevista ou simetria entre crescimentos e recessões. Desde Friedman \& Schwartz (1963) a ideia de que o sistema financeiro guarda explicação sobre ciclos está desenhada. Apesar disso, a extensa maioria dos estudos em Macroeconomia não modelam com nitidez a estrutura financeira dos países. Fazem uso de simplicidade metodológica para agregar diferentes tipos de ativos financeiros - ações, títulos, empréstimos bancários e outros financiamentos - em um único mercado agregado de fundos mútuos emprestáveis, que é homogêneo e bem-comportado.

Ignorar a estrutura financeira em modelos macroeconômicos não decorre de premissa conceitual ou falta de interesse de pesquisa, argumentam Diaz-Gimenez et al. (1992), mas sim da ausência contemporânea de ferramentas adequadas para solucionar modelos de dimensões maiores.

Por sua vez, os modelos de Microeconomia Bancária são construídos para explicar os fatos estilizados do setor bancário e o comportamento específicos dos agentes, não tendo a agenda de estudar trade-offs micro-macro. Em sua maioria, tais modelos partem de conceitos muito especializados e têm motivações diferentes de estudar interconexões estruturais. Também possuem dificuldades metodológicas e tecnológicas para construir uma interação mais complexa de conceitos, especialmente aqueles que tratem de agregados macroeconômicos. Os textos em- 
píricos sobre mercados financeiros argumentam que não existe um modelo único e generalizado de intervenção capaz de explicar um mesmo resultado de desenvolvimento financeiro e que os países adotam estruturas de intervenção muito particulares, como mostram (BARTH; CAPRIO; LEVINE, 2002), por exemplo. Isso justifica a sobrevivência teórica de tantos modelos e sua diversidade de resultados, as vezes contrários entre si.

É certo que a nova teoria de banking analisa a indústria bancária considerando a existência de fricções, mas a discussão sobre os seus efeitos no mercado bancário e na economia como um todo têm incentivado a produção de pesquisas sobre a integração entre áreas de interesse diferentes, como competição e estabilidade, ou competição e fragilidade financeira. Em geral, trabalhos nessa linha têm alguma intersecção com a preocupação da tese, de explorar trade-offs entre objetivos diferentes, embora não possuam a mesma pergunta, nem o mesmo propósito generalista.

\subsubsection{Eficiência Microeconômica e Estabilidade Macroeconômica}

As fricções do mercado bancário têm consequências para a eficiência econômica na medida em que os teoremas de bem-estar não são aplicáveis. O equilíbrio ótimo competitivo sob tais condições será sempre do tipo second best. Por exemplo, Stiglitz \& Weiss (1981) analisaram como a interação entre fricções da firma bancária podem alterar a alocação dos recursos e implicar em ineficiência microeconômica. Os autores definem eficiência alocativa quando todos os projetos de investimento das firmas que possuem as maiores rentabilidades esperadas são financiados e quando nenhum projeto cujo retorno a valor presente é positivo deixa de ter financiamento. $\mathrm{O}$ preço do crédito é a taxa de juros do mercado, que deve se ajustar para garantir essa condição de eficiência. Porém, os autores mostram que a determinação da taxa de juros ocorre sob informação imperfeita porque ou os bancos não conseguem estimar o risco de inadimplência dos projetos ou os bancos não conseguem monitorar as ações dos tomadores de empréstimos. Dessa forma, a falha de mercado é responsável por gerar uma alocação ineficiente, que trará impactos

sobre o investimento agregado, produção e consumo (STIGLITZ; WEISS, 1981; STIGLITZ; WEISS, 1992). 
Por sua vez, Kiyotaki \& Moore (1997) argumentam que a assimetria no contrato de crédito entre bancos e empreendedores determina uma interação dinâmica entre os limites de crédito e os preços dos ativos de tal forma que choques pequenos na tecnologia ou na distribuição de renda podem gerar flutuações altas no produto e nos preços dos ativos. Ainda, esse mecanismo de transmissão entre o lado real e o lado financeiro da economia pode gerar persistência e ampliação de choques e afetar efetivamente os demais setores da economia real.

Os resultados chamam a atenção para efeitos agregados de imperfeições na indústria de crédito. É razoável concordar que as conclusões dos macro-modelos devem ser sensíveis à forma como são modeladas as instituições financeiras. A conclusão é que a estrutura de alocação de recursos deve explicar alguma fração relevante do processo de crescimento das economias. Portanto não faz sentido ignorar as imperfeições financeiras em modelos macroeconômicos, exceto por simplicidade metodológica e apenas quando o objeto de estudo não esteja relacionado à forma como os recursos são distribuídos.

De maneira inesperada, os textos em Macroeconomia tem poucos modelos a apresentar nos quais exista uma especificação explícita do setor bancário e de sua organização industrial. Mesmo quando a modelagem inclui bancos de forma explícita, faz de forma simplista, como em Diaz-Gimenez et al. (1992): os bancos são apenas firmas específicas, capitalizadas pelas famílias que poupam para aposentadoria, e que ofertam crédito para atender i) a necessidade de firmas de financiar antecipadamente sua folha de salários e ii) a necessidade das famílias de financiar imóveis.

Mais recentemente, a interação entre banking e Macroeconomia tem destacado a modelagem dos canais de transmissão de política monetária nos textos em que a visão de crédito é relevante. Se a transmissão de política monetária é aquela defendida pela visão de crédito, em contraponto à visão de moeda, então as fricções setoriais serão cruciais para o resultado macroeconômico (FREIXAS; ROCHET, 2008, Cap. 6).

A visão de crédito contempla a existência de dois conhecidos canais de transmissão: o broad 
credit channel, ou balance sheet channel, supõe que os fundos próprios são substitutos imperfeitos do crédito bancário no financiamento demandado pelas firmas; e o bank lending channel enfatiza a transmissão pela existência única do crédito bancário para o financiamento da firma. Mishkin (1996) pondera que os canais de crédito representam a interpretação mais detalhada de como as taxas de juros de fato afetam a economia, em contraponto à visão simplificadora do tradicional canal de taxa de juros.

\section{Os Canais de Transmissão Monetária}

Mishkin (1995) explica os diversos canais pelos quais as decisões sobre a oferta de moeda chegam à economia real ${ }^{5}$. O canal de taxa de juros é o mais tradicionalmente conhecido, a política monetária afeta diretamente o custo de capital. Outros canais identificados são os canais relacionados a preços - taxa de câmbio, preço das ações e demais ativos - e os canais de crédito bank lending e balance-sheet.

Bernanke \& Blinder (1988) identificam duas condições como necessárias para a existência do canal de crédito bank lending: i) firmas devem ser, por alguma razão, dependentes de empréstimos bancários, havendo impossibilidade de substituir o crédito bancário por outros financiamentos sem incorrer em custos; e ii) a autoridade monetária deve ter instrumentos capazes de manipular a oferta de crédito da economia.

A capacidade da autoridade monetária alterar a oferta de crédito é questionada em Romer \& Romer (1990). Os autores afirmam que bancos sempre terão à disposição meios de financiamento alternativos e sem custos adicionais, que garantam que essas firmas compensem a queda nos depósitos com outros meios de captação, por exemplo a capitalização no mercado de ações. Nesse caso, eles argumentam pela validade do teorema da irrelevância de Modigliani \& Miller (1958) para a indústria bancária. Kashyap \& Stein (1994) mostram que bancos não realizam o ajustamento da queda de depósitos tão facilmente, incorrendo em custos consideráveis para

\footnotetext{
${ }^{5}$ Ver também em Mishkin (1996).
} 
captar recursos, sendo inevitável repassá-los às condições de oferta de crédito. Resultados empíricos como em Bernanke \& Blinder (1992), Kashyap \& Stein (1994) e Kashyap \& Stein (2000) encontram que bancos que não são perfeitamente indiferentes a fontes de captação e, portanto, o teorema de Modigliani \& Miller (1958) não é válido para essas firmas.

Bernanke \& Gertler (1995) chamaram de "caixa preta" a conexão entre as políticas macroeconômica de oferta de moeda e os efeitos microeconômicos percebidos por firmas e famílias. Argumentam que o canal de transmissão de taxa de juros, conforme descrito por Keynes, não tem sustentação empírica. Segundo os autores, existem três puzzles importantes na explicação proporcionada pelo mecanismo monetário tradicional de propagação de política monetária: há diferenças entre a evidência empírica e aquilo que é previsto pelo canal tradicional quanto à magnitude, ao timing e à composição dos efeitos sobre a demanda agregada. Bernanke \& Gertler advogam que os canais de crédito descrevem melhor a penetração das decisões de política monetária para a economia real. De maneira descritiva, os autores detalharam os canais bank lending e balance-sheet para a economia americana e concluíram que os canais de crédito são o principal mecanismo de propagação da política monetária.

Os textos nacionais têm contribuições sobre a existência e operação dos canais de crédito na transmissão de política monetária. Em revisão da literatura teórica e empírica, Sobrinho (2003) sintetiza em quatro pontos essenciais a transmissão pelos canais de crédito: i) as assimetrias informacionais, em essência, definem a existência desses canais; ii) os canais de crédito são mecanismos adicionais de transmissão do choque monetário; iii) a efetividade da política monetária é diretamente influenciada pelos canais de créditos; e iv) os canais de crédito apresentam potencial explicativo para relacionar a estrutura do sistema financeiro com as flutuações econômicas.

Os estudos de Sobrinho (2003) e Sobrinho \& Nakane (2002) apresentam evidências empíricas descritivas e econométricas favoráveis à existência do canal bank lending de transmissão na economia brasileira para o período posterior ao Plano Real. Resultado congruente aos observados por Takeda, Rocha \& Nakane (2003) e Oliveira \& Neto (2008), que encontraram evidências 
da existência e da relevância do canal de empréstimos bancários no Brasil.

Com outro objeto de análise, Rocha (2007) analisa os efeitos regionais da transmissão da política monetária. Os resultados mostram sensibilidade regional aos choques comuns de política monetária: os estados das regiões Norte e Nordeste do país recebem maior impacto de choques de política monetária do que estados do Centro-Sul brasileiro. A interpretação do autor é que existe e atua um canal de crédito no país para o qual a assimetria regional é explicada por problemas informacionais. Mais especificamente, Rocha argumenta pela atuação do balance sheet channel no Brasil porque constata que estados que possuem maior número de pequenas firmas, portanto maior demanda de crédito, são aqueles com maior sensibilidade à política monetária.

Se os canais de créditos são importantes, então a pergunta da tese se justifica. Que implicações têm os instrumentos regulatórios ativos, técnicos e prudenciais, sobre a concessão de crédito e como isso afeta a transmissão e a eficácia da política monetária? Se a política monetária está entre os temas mais debatidos em Macroeconomia, raros são os estudos econômicos que consideram a importância da estrutura e do funcionamento do mercado bancário.

\section{Competição e Transmissão Monetária}

Smith (1998) utilizou um modelo de equilíbrio geral para estudar os custos macroeconômicos da competição imperfeita na indústria bancária. $\mathrm{O}$ autor aponta que falhas de competição são introduzidas por instrumentos de regulação cujo objetivo é dar estabilidade ao sistema bancário. A análise de bem-estar empreendida não se mostrou efetiva porque trouxe conclusões ambíguas mesmo após uma análise complexa, mas a comparação em termos de performance macroeconômica indicou com nitidez que aumento de competição na indústria bancária gera mais renda e diminui o tamanho dos ciclos. Os efeitos quantitativos macroeconômicos podem ser elevados.

Resultados contrários foram obtidos por Alencar \& Nakane (2004). A estrutura de mercado do 
setor bancário afeta sensivelmente o desempenho da política monetária. O contrato bancário entre empreendedores e bancos contém assimetria de informação no retorno do tomador de crédito e existe uma tecnologia de verificação do contrato disponível para o banco, seguindo Townsend (1979) e Gale \& Hellwig (1985). Os resultados mostraram que existe trade-off micro-macro: a competição bancária implica em mais flutuação do produto. A explicação é que o aumento da competição bancária e a tecnologia de verificação mais eficiente reduzem a reação do spread bancário e da inadimplência setorial a choques de juros; a influência da tecnologia de verificação na resposta da economia a choques é tanto maior quanto mais competitiva for a indústria bancária.

Fuerst (1995) verificou de maneira quantitativa se imperfeições do mercado financeiro acentuam a propagação de choques sobre a acumulação de capital físico e, dessa forma, se podem impactar a economia mais do que os modelos da literatura tradicional de RBC argumentam. Fuerst constrói um modelo de gerações sobrepostas no qual descreve o problema de agência para o setor de capital físico. Existe informação assimétrica na tecnologia do empreendedor que converte bens de consumo em bens de capital. A conclusão do artigo é que os custos de agência acrescentam pouco ao mecanismo de propagação tradicional de Business Cycles, porém Fuerst pondera que estudar o setor de intermediação financeira ainda é relevante para a literatura RBC porque dele advém choques específicos setoriais que impactam direta e persistentemente no setor produtivo. Carlstrom \& Fuerst (1997) retomam o assunto e mostram, por sua vez, que os custos de agência funcionam bem para explicar a autocorrelação do produto ao longo dos ciclos de negócios. Os autores argumentam ainda que custos de agência e custos de ajustamento do capital têm a capacidade de gerar propriedades semelhantes de timing e persistência para a oferta de capital.

\subsubsection{Estabilidade Macroeconômica e Fricções Financeiras}

Allen \& Gale (2000) concluíram, com rigorosa análise empírica cross-country sob numerosas bases de dados, que os países apresentam estruturas financeiras diferentes, em diversos aspectos, mesmo se controlando pelo seus respectivos graus de desenvolvimento econômico. Os re- 
sultados empíricos da comparação da estrutura financeira dos países sempre trouxeram poucos esclarecimentos e recomendações, mas um dos resultados mais sobressalentes é que maior estabilidade financeira é observada por países que adotam políticas em favor do livre mercado em comparação com países com presença forte do Estado no setor (BARTH; CAPRIO; LEVINE, 2000; BARTH; CAPRIO; LEVINE, 2001; BARTH; CAPRIO; LEVINE, 2002; BARTH; CAPRIO; LEVINE, 2005). É necessária uma observação nesse ponto: a defesa de uma regulação menos incisiva, cujo propósito seria apenas gerar incentivos à competição de mercado, era recorrente nos textos de banking até a ocorrência da atual crise financeira ${ }^{6}$. A ideia dominante era que o regulador deveria pouco intervir e as políticas deveriam ser mais específicas às características das firmas e do setor, com o objetivo de promover a concorrência e a estabilidade financeira. Nesses termos, políticas de regulação por incentivos são preferíveis por produzir respostas endógenas do mercado às assimetrias informacionais e à capacidade limitada de observação do regulador, ao contrário de mecanismos exógenos definidos pela regulação tradicional, por exemplo os requerimentos de capital. A regulação por incentivos é apropriada quando as firmas possuem melhores informações sobre o setor do que conhece o regulador, ou ainda quando sociedade e firmas não possuem objetivos mutuamente compatíveis (SAPPINGTON, 1994).

O mainstream em Macroeconomia tem dedicado certo interesse atual em entender o papel de fricções financeiras na determinação dos resultados agregados. Estudos muito recentes que usam as técnicas modernas de modelagem e estimação têm se preocupado em entender melhor como o resultado macroeconômico pode ser afetado por choques específicos do sistema bancário. Nessa abordagem, Gerali et al. (2010) estudam o papel da oferta de crédito nas flutuações da economia utilizando um modelo com várias fricções para o mercado bancário. Os autores argumentam que os choques específicos do mercado bancário explicam a maior fração da queda do produto europeu em 2008, enquanto outros choques explicam menos. A identificação dos choques foi feita por estimação bayesiana de um modelo DSGE. A principal contribuição dos autores está na interação da estrutura dos bancos com ciclos de negócios.

\footnotetext{
${ }^{6}$ Vem em Freixas \& Rochet (2008), Barth, Caprio Jr. \& Levine (2006) e Allen \& Gale (2000) uma compilação desses textos.
} 
Goodfriend \& McCallum (2007) incorporam moeda a um modelo macroeconômico da Nova Síntese Neoclássica com a desagregação para o setor bancário, embora não descreva explicitamente bancos e sua organização industrial. A conclusão principal dos autores é que o aumento de preços dos ativos implica em aumento do colateral na economia e redução da demanda por crédito, afetando portanto o processo de acumulação de capital. Assim, choques específicos da produtividade bancária ou sobre a efetividade do colateral das firmas podem solicitar respostas em termos de política monetária mais rígidas do que aquelas previstas por modelos sem bancos.

Com uma proposta diferente de fundamentação microeconômica para o setor bancário e demanda por crédito, Diamond \& Rajan (2006) constroem um modelo macroeconômico com moeda e bancos com o rigor analítico atual para motivar o problema de administração da liquidez. A atividade bancária está sujeita a restrições de liquidez que decorrem do balanço operacional dos bancos. O banco recolhe recursos do setor privado e oferta crédito para projetos do setor produtivo, mas deve manter certa liquidez para saques, pagamentos e compensações entre os agentes. Os ativos têm menor liquidez que os passivos bancários e a administração de portfolio é absolutamente relevante na operação do mercado, definindo um canal de liquidez para transmissão da política monetária. Uma característica importante do modelo são corridas bancárias endógenas, como em Diamond \& Dybvig (1983). A conclusão principal dos autores é que os bancos ampliam eventuais quedas no produto real, gerando redução persistente no produto total.

Canzoneri et al. (2008) complementam o ponto de vista de Goodfriend \& McCallum sobre os riscos de fazer política monetária com um modelo macroeconômico simplificado sem moeda nem bancos e propõe a abordagem de banking em um framework neo-wickselliano a la Woodford (2003). Os autores questionam a precisão de modelos simples para descrever o comportamento macroeconômico em comparação a um modelo completo com bancos e moeda. Os resultados mostram que o modelo completo se ajusta melhor aos dados. Os autores interpretam a diferença entre $5 \%$ e $20 \%$ como liquidity buffering effect e concluem que o papel dos intermediários financeiros é bastante relevante para explicar a maneira como choques de taxas de juros e de produtividade afetam a economia real. 
Edwards \& Vegh (1997), por sua vez, constroem um modelo DSGE simples de economia aberta com câmbio predeterminado para avaliar como o setor bancário afeta a propagação de choques. Choques e ciclos de negócios internacionais sobre o sistema bancário afetam o produto e o emprego mediante flutuações no crédito bancário. Os autores apontam requerimentos de reservas contra-cíclicos como sugestão para atenuar o problema de pró-ciclicidade. As evidências empíricas para Chile e México comprovam as previsões do modelo sobre absorção de choques mundiais, como aqueles ocorridos na década passada.

Outros estudos específicos em resiliência financeira também mostram contribuições ao tema, embora estejam particularmente interessados em avaliar resultados das recomendações de Basileia. Tanaka (2002) pondera que os acordos prudenciais até geram incentivos para a redução do comportamento arriscado dos bancos, mas podem reduzir a oferta de crédito a firmas pequenas e médias que se financiam no mercado bancário. A autora também argumenta que os requerimentos de capital constantes no acordo são pró-cíclicos com as flutuações dos empréstimos bancários, com impactos sobre o mecanismo de transmissão monetária.

Tchana (2007) analisa o trade-off entre a estabilidade promovida por regulação prudencial e o prejuízo em termos de crescimento econômico menor em decorrência de limitações no crédito. Em termos de bem-estar, o autor mostra que a regulação oferece ganhos quando os choques são suficientemente elevados e os agentes econômicos são suficientemente avessos a risco.

\subsubsection{Eficiência Microeconômica e Resiliência Financeira}

Em um modelo de equilíbrio geral Arrow-Debreu, os teoremas do Bem-Estar garantem que a competição perfeita é condição necessária para eficiência alocativa. De forma análoga, Allen \& Gale (2004b) mostram que esse resultado se mantém para um modelo de crises financeiras com mercados completos e que competição perfeita é compatível com o nível eficiente de estabilidade financeira.

A intervenção do Estado que tem propósito de promover competição do setor bancário pode 
ser bom para a eficiência econômica em uma análise estática, mas seus impactos dinâmicos evidenciam problemas para a estabilidade financeira (ALLEN; GALE, 2004a). Sob o ponto de vista de bem-estar, os autores avaliam variados modelos para responder quais são os níveis eficientes de competição e estabilidade financeira. Instabilidade financeira é definida como o encerramento do contrato de crédito por declaração de falência do banco. As respostas são diferentes de acordo com o modelo que aborda o problema. O relacionamento entre competição e estabilidade é complexo porque em certos casos a competição aumenta a estabilidade, analisam os autores, exemplificando a tese com um modelo de equilíbrio geral com motivação schumpeteriana. Outros modelos mostraram que concentração poderia ser socialmente preferível à competição ou ainda que estabilidade perfeita poderia ser socialmente indesejável. Alguma instabilidade financeira poderia ter vantagens econômicas porque: i) auxilia na redução do problema de moral hazard do banqueiro (GALE; VIVES, 2002), ii) fazem os pagamentos aos depositantes serem contingentes no retorno (ALLEN; GALE, 1998) e iii) promovem comprometimento e liquidez (DIAMOND; RAJAN, 2001).

A literatura indica que há trade-off entre concorrência e estabilidade. A explicação tradicional é que o aumento de competição leva os intermediários financeiros a assumirem riscos maiores, seja na captação de recursos e ou na concessão de crédito, para manter certo nível de retorno. Nos estudos empíricos, entretanto, é observado com recorrência o trade-off entre concentração e estabilidade, mas o resultado não é conclusivo se a análise se dá entre concorrência e estabilidade. Portanto, os estudos nesse tópico não tem conclusões definitivas, nem fatos estilizados.

A existência de trade-off entre competição e estabilidade financeira sugere como política prudencial aumentar a regulação do setor bancário para garantir a estabilidade financeira com menos competição. Allen \& Gale (2000) argumentam que, se por um lado o custo da instabilidade financeira é muito elevado e tangível, por outro lado há dificuldade de se medir os custos em termos de eficiência da concentração setorial. É, portanto, uma consequência natural que os países dediquem maior prioridade na prevenção de crises em detrimento de políticas promotoras de competição. 
Keeley (1990) mostrou evidências teóricas e empíricas de que a desregulação do mercado financeiro americano, entre as décadas de 1970 e 1980, aumentou a competição setorial mas amplificou o problema de agência entre administradores de bancos e o seguro-depósito. Dada a garantia do fundo sobre alguma fração dos depósitos bancários, os administradores levam em consideração esse estado da natureza e têm incentivo para tomar risco extra, aumentando o lucro esperado (Charter Value).

O instrumento tradicional utilizado em políticas promotoras de resiliência financeira são os requerimentos de capital mínimo para operação dos bancos. O Acordo de Basileia I recomenda desde 1988 o controle de capital para bancos com o propósito de gerar incentivos para que essas firmas tomem menos riscos, com alavancagem menor, mas mantendo a estrutura competitiva do mercado. Hellman, Murdock \& Stiglitz (2000) mostraram todavia que, em modelos de moral hazard, os controles de capital não são suficientes. Com a taxa de remuneração dos depósitos determinada de forma livre, os bancos têm incentivos para competir no mercado de depósitos pagando taxas mais elevadas. Em consonância com Keeley (1990), na linha de que maior intervenção define mais estabilidade, os autores advogam que qualquer equilíbrio Paretoeficiente pode ser implementado por uma combinação entre controle da taxa de remuneração dos depósitos bancários e requerimentos de capital.

Simultaneamente, Matutes \& Vives (2000) estudaram de forma ampla as relações entre competição por depósitos bancários e incentivos à tomada de riscos pelos bancos. Os autores discutem as implicações de bem-estar da competição bancária sob diferentes regimes de seguro-depósito para uma estrutura bancária em competição imperfeita na qual os bancos estão sob comprometimento limitado. Os custos sociais da falência bancária são computados e os resultados apontam que o bem-estar e as medidas de regulação adequadas dependem do grau de competição e do regime do fundo de garantias aos depósitos. Quando a competição é elevada, os custos de falência são altos e as taxas de juros sobre os depósitos são excessivas tanto no mercado desregulado quanto no mercado com seguro. Isso também acontece porque o prêmio de seguro não é sensível ao risco, independente do custo social de falência. Por outro lado, mercados não regulados com portfolio não-observável ou regulados com seguro-depósito não 
contingente são complementares às restrições sobre ativos na determinação do bem-estar. Em um mercado não regulado com portfolio observado ou segurado contra riscos, a regulação das taxas de juros de depósitos pode ser suficiente para garantir o bem-estar.

Também em termos empíricos, a relação entre estrutura de mercado e fragilidade financeira tem sido explorada na literatura. Beck, Demirguç-Kunt \& Levine (2003) analisaram dados para setenta países entre 1980 e 1997 para promover interpretações sobre a responsabilidade da concentração e das intervenções sobre o setor bancário para a possibilidade de ocorrência de crises sistêmicas. Os resultados confirmam que crises bancárias são menos prováveis de acontecer em: i) estruturas de mercado bancário mais concentradas; ii) mercados com menos restrições regulatórias sobre a competição bancária, principalmente barreiras à entrada; ou iii) ambientes com instituições fortes e bem consolidadas que promovem a concorrência setorial.

Os trabalhos que analisam possíveis trade-offs entre os conceitos de eficiência de mercado, resiliência financeira e estabilidade macroeconômica desenvolvem suas análises aos pares e nem todos utilizam o paradigma de equilíbrio geral walrasiano, razão pela qual, em alguma medida, estão sujeitos à Crítica de Lucas Jr. (1976), porque desconsideram a possibilidade de ajustamento da economia em outras dimensões. Não é conhecido na literatura estudo que modele o setor bancário de forma explícita em equilíbrio geral dinâmico e estocástico e descreva os três objetivos/conceitos apresentados, com o propósito de analisar o comportamento daquele mercado.

Em síntese, a literatura econômica tem demonstrado o esforço de pesquisa para compreender melhor as implicações das fricções financeiras sobre a economia como um todo. No contexto do problema que a monografia trata, os estudos apresentados possuem limitações conceituais e metodológicas para responder às questões apresentadas. De forma geral, a literatura não res- 
ponde de forma satisfatória porque os estudos i) não contemplam os três objetivos identificados das intervenções do Estado; ii) têm objetivos diferentes da análise de trade-offs das intervenções; iii) estão sujeitos à Crítica de Lucas pelo tratamento em equilíbrio parcial, especialmente a literatura de banking. Essa falta de explicação decorre em especial de alguns fatos: i) a regulação prudencial no âmbito internacional tem-se tornado relevante apenas nos últimos anos, os países ainda estão implementando suas legislações, enquanto outras nações sequer assinaram os Acordos de Basileia; ii) a modelagem integrada dos três objetivos é tarefa complexa; ii) a tecnologia de estimação requereria muitos dados inexistentes; iv) algum desinteresse da Economia da Regulação em tratar o mercado financeiro como conteúdo especial; e v) predisposição conceitual da literatura mainstream em favor da auto regulação dos mercados financeiros.

\subsection{A Evolução Técnica em Modelagem e Estimação}

Diaz-Gimenez et al. (1992) argumentaram que os modelos macroeconômicos do mainstream ignoravam a estrutura dos mercados financeiros não porque desprezem seu potencial explicativo, mas porque as tecnologias contemporâneas de modelagem não garantiam tratabilidade para modelos de grandes dimensões.

Os últimos vinte anos apresentaram notável evolução nas técnicas de modelagem de economias sob o paradigma de equilíbrio geral dinâmico e estocástico (DSGE - Dynamic Stochastic General Equilibrium), seja em termos de especificação, seja quanto a estimação estrutural. A popularidade de modelos DSGE pode ser explicada por características desejáveis, como i) a capacidade de se ajustarem aos dados econômicos; ii) ter resultados derivados de fundamentos econômicos; iii) descrever o equilíbrio econômico por meio de parâmetros estruturais. Ressalte-se que essa terceira característica representa a viabilidade da evolução da pesquisa macroeconômica depois da Crítica de Lucas (LUCAS JR., 1976).

Os desenvolvimentos recentes da literatura macroeconômica e da tecnologia empregada na modelagem permitem agora acrescentar complexidade à classe de modelos DSGE. Contudo essa classe de modelos tem sido principalmente utilizada na agenda estritamente macroeconômica, 
embora ofereça facilidades intrínsecas como flexibilidade, modularidade e capacidade analítica de descrição, que podem contribuir em outras direções. Em especial, são vantagens adequadas ao problema proposto nesta tese.

A incorporação de fricções em modelos macroeconômicos da família neoclássica tem sido a novidade em termos de especificação da literatura teórica denominada Nova Síntese Neoclássica (NNS - New Neoclassical Synthesis). Goodfriend \& King (1998) definem essa nova área de pesquisa como a convergência das agendas de pesquisa de novoclássicos e novokeynesianos, na qual os objetivos fundamentais são i) a análise de políticas macroeconômicas em termos aplicados; ii) a crença de que rigidezes de curto prazo são importantes para explicar flutuações econômicas; e iii) o alinhamento metodológico com o paradigma microeconômico de otimização de agentes racionais. Os estudos nessa área têm o compromisso de atender as hipóteses de expectativas racionais e de maximização intertemporal dos agentes, os programas keynesianos para a demanda agregada de determinação de preços e produto e as explicações da oferta agregada proposta pela teoria de Real Business Cycles. O foco prático na análise e formulação de políticas econômicas, seguindo as prioridades da agenda macro, como apontadas em Lucas Jr. (2003), é o que hoje une teorias conceitualmente divergentes de ontem.

As técnicas de estimação de modelos DSGE também evoluíam nas últimas décadas. O desenvolvimento computacional fez evoluir a metodologia de calibração pura para a estimação econométrica. Várias abordagens em Econometria estão disponíveis, como GMM (Generalized Method of Moments), máxima verossimilhança e métodos bayesianos. Esses últimos têm recebido atenção recente pela necessidade de menor volume de dados econômicos e pela disponibilidade de novas ferramentas computacionais.

A obtenção de maior aderência entre os resultados delineados por modelos teóricos estruturais e as evidências empíricas justificam porque os modelos DSGE hoje são usados por banco centrais de economias desenvolvidas e emergentes enquanto ferramenta de análise de política econômica e de previsão de médio prazo, seja de forma protagonista ou auxiliar aos métodos VAR. As características de que esses modelos estão micro-fundamentados e que o equilíbrio 
econômico é bem determinado como a solução simultânea de problemas de otimização dos agentes econômicos justificam o investimento da literatura atual nessa classe de modelos.

Se os benefícios de um framework integrado com dados para a análise econômica de políticas e a previsão de cenários são óbvios, os modelos DSGE também são utilizados para tomada de decisão dos policymakers. Tovar (2008) argumenta que a natureza complexa dos modelos solicita evolução de técnicas de modelagem e necessidade computacionais. A complexidade ainda dificulta a aceitação e difusão de modelos entre tomadores de decisão e sua comunicação com técnicos graduados. Os custos de formação de capital humano podem ser elevados para os formuladores de políticas, especificamente bancos centrais, e, por tal razão não recebem a devida prioridade.

O modelo básico geral DSGE incorpora conhecidas fricções nominais e reais (SMETS; WOUTERS, 2003; SMETS; WOUTERS, 2007; CHRISTIANO; EICHENBAUM; EVANS, 2005). A preocupação principal de detalhar o arcabouço macroeconômico é, portanto, garantir mais estreita relação entre resultados de modelo e resultados empíricos, especialmente aqueles estimados sob a metodologia VAR/BVAR. O modelo mais aderente aos dados é o mais adequado para análise de políticas. Em contraponto a essa visão dominante, Kocherlakota (2007) pondera que a rejeição ou aceitação de um modelo baseada apenas na sua capacidade de explicar os dados é uma decisão equivocada. Um modelo estrutural que se ajusta muito bem aos dados pode contudo ser errado para formulação de políticas. Para exemplificar, o autor constrói um modelo em que os dados são perfeitamente explicados, todavia o modelo não consegue gerar previsões razoáveis para uma intervenção de corte de impostos por que a elasticidade da oferta de trabalho não é identificada. O motivo de o modelo, apesar de bem ajustado aos dados, não conseguir desempenhar previsões aceitáveis é a inclusão de uma restrição inválida para a elasticidade. A solução apontada por Kocherlakota é realizar a abordagem bayesiana sempre com análises de sensibilidade dos valores inicialmente calibrados.

Modelos mais detalhados ajustam-se melhor aos dados mas possuem problemas de identificação de seus parâmetros comportamentais. Há, portanto, um trade-off entre parcimônia e 
acurácia. Os modelos de escala média em macroeconomia são um aprimoramento ainda mais recente da capacidade descritiva da economia possível nesse arcabouço em uma época em que a pesquisa teórica predominante aponta no sentido de adicionar mais estrutura econômica. Modelos como Schmitt-Grohé \& Uribe (2005) ou Adolfson et al. (2008) acrescentam extensivamente rigidezes nominais e reais com fundamentação microeconômica e têm os propósitos de melhorar a explicação analítica e obter previsões baseadas em um modelo estrutural. Essa recente literatura vale-se da desagregação tanto quanto for suficiente para descrever especificidades da organização setorial e institucional da economia, com o intuito de trazer à tona patologias de mercados com uma modelagem microeconômica rigorosa. A microeconomia desses modelos deve possuir características convenientes e simplificadoras - hipóteses técnicas e/ou econômicas - para tornar viável a agregação.

\subsection{Em Busca de uma Teoria para Bancos e Ciclos de Negócios}

Conforme argumentado anteriormente, a Macroeconomia está em busca de uma teoria que explique o papel das fricções financeiras sobre as variáveis macroeconômicas. Grandes esforços nesse sentido tem sido empenhados recentemente, mas os textos seguem duas linhas de análise. Uma vertente de pesquisa descreve as fricções financeiras e os canais de transmissão descrição de intermediários financeiros, buscando analisar efeitos amplificadores ou atenuadores de choques na economia. O segundo caminho está no entendimento dos choques originados no setor financeiro e como eles perturbam os agregados macroeconômicos. Embora haja necessidade e justificativa de pesquisa, ainda são poucos os textos macroeconômicos que modelam explicitamente os bancos e sua organização industrial.

Diversos artigos recentes, oriundos principalmente de centros de pesquisas de bancos centrais e da academia internacional, ainda que em versões preliminares, têm buscado contribuir com a discussão. Todos apresentam objetivos próximos e abordagens semelhantes na modelagem de bancos, embora não detalhe a organização industrial ou as restrições de ambiente como será feito nesta tese. Sobre tais artigos, cite-se Christensen et al. (2007), Curdia \& Woodford (2008), Andrés \& Arce (2009), Goodfriend \& McCallum (2007), Diamond \& Rajan (2006) e 
Iacoviello (2008), por exemplo.

A contribuição de Gerali et al. (2010) demonstra melhor a direção atual da pesquisa macroeconômica. Os autores tem como objetivo analisar o papel da oferta de crédito ao longo dos ciclos de negócio dos últimos anos para as economias da zona do Euro. Utilizando um modelo em escala média, eles constroem conexões da operação do mercado com a oferta de crédito da economia e com ciclos de negócios na produção bancária. Os resultados mostram que flutuações geradas pelo setor bancário explicam retração do produto na região durante a crise financeira, ao passo que outros choques macroeconômicos têm importância reduzida. O texto conversa bem com o modelo proposto na tese porque descreve a estrutura patrimonial do banco com detalhes, embora os resultados e o objeto de estudo sejam outros.

Com outro objetivo, mas metodologia muito semelhante, Gertler \& Kiyotaki (2009) modelam fricções sobre o crédito descrevendo firmas bancárias e o mercado interbancário. Utilizam o arcabouço para avaliar a geração de crises a partir de estresses em condições do modelo e analisar as intervenções do governo americano utilizadas para controlar a crise financeira recente, notadamente políticas de crédito direto, empréstimos de liquidez, compra de ações de instituições financeiras e gastos públicos.

A alternativa que apresenta maior rigor técnico na incorporação de fricções financeiras, como contratos de crédito, em um framework DSGE é a modelagem em equilíbrio parcial de bancos e tomadores de crédito, seguida da agregação dos resultados e consideração das relações que advém do equilíbrio parcial na determinação do equilíbrio geral da economia. Essa proposta foi iniciada por Bernanke \& Gertler (1989) e foi seguida em diversos trabalhos subsequentes como Fuerst (1995), Carlstrom \& Fuerst (1997), Bernanke, Gertler \& Gilchrist (1999), Smith (1998), Alencar \& Nakane (2004), Christiano, Motto \& Rostagno (2007). A abordagem é a mais adequada disponível atualmente para tratar conteúdo de natureza microeconômica dentro de um modelo macro. O modelo do acelerador financeiro - conhecido como BGG (BERNANKE; GERTLER; GILCHRIST, 1999) - tornou-se então a abordagem mais recorrente para incluir fricções financeiras sob o contexto de equilíbrio geral. 
Dentre os modelos que usam do acelerador para descrever as fricções financeiras, Christiano, Motto \& Rostagno (2007) é destacado na análise da importância delas para explicar ciclos de negócios. Os autores encontram que a rigidez nominal em contratos de crédito implicam em efeitos amplificadores importantes na dinâmica dos choques financeiros. Os resultados empíricos mostram que o acelerador financeiro é relevante para explicar a amplificação e persistência de choques nas economias americana e da zona do Euro. Por sua vez, Hall (2001) estuda o acelerador financeiro na economia britânica e verifica que sua atuação é profícua para explicar flutuações nos agregados econômicos. As críticas a essa classe de modelos estão relacionadas à descrição de apenas um tipo de fricção financeira, simplória diante da extensão das fricções na intermediação financeira reconhecidas na literatura de banking.

Goodfriend \& McCallum (2007) criam fricções financeiras no crédito e dois tipos de choques relacionados ao setor financeiro. O mecanismo de transmissão está sustentado na demanda por moeda e na função de produção de crédito. A exigência de colateral com ativos mais líquidos na produção cria fricção na oferta de empréstimos, porque gera renda de serviços de liquidez para sustentar o crédito. Os autores ponderam que existem dois efeitos significantes das fricções sobre as variáveis macroeconômicas: acelerador, que advém do tradicional broad credit channel seguindo Bernanke, Gertler \& Gilchrist (1999), ou atenuador, quando a depressão dos depósitos faz cair a demanda por moeda e reduz o colateral do banco. Os autores ponderam que a prevalência está ligada à característica do choque.

Em geral, a nova e recente classe de modelos que busca entender efeitos macroeconômicos de fricções financeiras já apresenta poucas congruências e muitas divergências, como resume Arend (2010). Embora os modelos de equilíbrio geral que incluem fricções apresentem ganhos na explicação de variáveis macroeconômicas em relação às abordagens mais simples, não é pacífico como a intermediação financeira deve ser incluída nem qual dos mercados de crédito é o mais relevante. Os modelos que apenas imputam choques financeiros têm menor sucesso relativamente aos que descrevem intermediários e fricções.

Em rápida exploração da literatura atual, verificou-se que os textos recentes estão, portanto, em 
busca de construir a conexão entre bancos e setor real, admitindo naturalmente a prevalência dos canais de crédito na transmissão monetária, mas sempre com o objetivo mater de melhorar o entendimento das flutuações econômicas. A interação entre os conceitos como aqui é proposta não está dentre as prioridades da agenda de pesquisa macroeconômica. 


\section{Capítulo 2}

\section{O MODELO DSGE COM FRICÇÕES BANCÁRIAS}

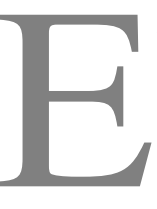

STE CAPÍTULO apresenta com detalhes, resolve e analisa o modelo dinâmico e estocástico de equilíbrio geral (DSGE) que descreve em escala média o ambiente econômico, com detalhamento principal do sistema bancário e suas fricções. A modelagem e as conclusões deste capítulo são basilares para os resultados posteriores. A metodologia de modelagem segue os estudos da Nova Síntese Neoclássica, na qual se incluem rigidezes nominais e reais, como Christiano, Eichenbaum \& Evans (2005), Smets \& Wouters (2003) e Schmitt-Grohé \& Uribe (2005). A escala média permite descrever com mais precisão microeconômica o mercado bancário, sua organização industrial e as relações que afetam a oferta de crédito para agentes privados e para o governo.

O modelo pode ser sintetizado em seis grandes blocos:

1. Economia real: Há um único bem final que é um composto de bens intermediários e o mercado de bens intermediários é estruturado em competição imperfeita, como tradicionalmente é apresentado em diversos textos macroeconômicos modernos. Cite-se Smets \& Wouters (2003), Christiano, Eichenbaum \& Evans (2005), Schmitt-Grohé \& Uribe (2005) como aqueles que apresentam convergência na descrição da economia real; 
2. Mercados financeiros: operam diversos ativos, mas as firmas e empreendedores não têm acesso direto, somente via bancos. Os bancos são modelados dentro de uma estrutura de mercado em competição imperfeita. A falha de competição é um ponto-chave para motivar a regulação técnica e a intervenção prudencial. É necessário que essa estrutura competitiva responda de maneira endógena, em alguma medida, às variações nas intervenções do Estado;

3. Contrato bancário: elemento fundamental para a interface de transmissão micro-macro, o contrato bancário será descrito como na literatura tradicional, seguindo Bernanke, Gertler \& Gilchrist (1999), Carlstrom \& Fuerst (1997), Smith (1998), Alencar \& Nakane (2004) e diversos outros textos. O crédito privado para o investimento é realizado por contratos financeiros de dívida firmados entre bancos e empreendedores. O banco resolve um problema de agência para definir a oferta em cada mercado, ressaltando sua característica como gestor de ativos;

4. Banking: descreve-se com detalhes o balanço patrimonial do banco, o gerenciamento intertemporal da liquidez e a tecnologia de produção de crédito. A estrutura da indústria bancária é de concorrência monopolística com diferenciação do produto crédito para cada mercado;

5. Mecanismos de transmissão de política monetária: estão modelados o bank lending credit channel, que é o impacto da taxa de juros diretamente sobre o passivo bancário, com impactos sobre a disponibilidade de recursos para ofertar crédito; e o balancesheet credit channel (também conhecido como broad credit channel), que é o efeito de alterações nos juros sobre a capacidade de financiamento dos empreendedores (external finance), transmitidas no tempo pelo a+celerador financeiro;

6. Governo: o governo tem política fiscal passiva e política monetária ativa descrita por uma regra de juros para os títulos públicos. 
O capítulo está organizado em quatro seções. A primeira seção descreve com detalhes o modelo DGSE, desenvolvendo as condições de ótimo para cada conjunto de agentes econômicos. A seção dois constrói os conceitos relacionados à eficiência microeconômica e resiliência financeira, a partir de variáveis endógenas do modelo básico. A terceira seção define o equilíbrio geral competitivo da economia e pondera a existência do equilíbrio estacionário. Ainda na seção são apresentadas as formas funcionais e a calibração básica do modelo, que permitirão as simulações da tese. Na quarta seção são estudadas as propriedades do modelo calibrado, com o propósito de entender as interações entre os conceitos tanto na estática do equilíbrio quanto na dinâmica de ajustamento da economia a choques de política monetária.

\subsection{O Modelo da Nova Síntese Neoclássica com Fricções Financeiras}

Seja uma economia fechada e com governo. Existem cinco tipos de agentes na economia: famílias, firmas, produtores de capital, empreendedores e bancos, além do governo. Os bens finais produzidos pelas firmas são comprados pelas famílias para consumo e pelos empreendedores para investimento, ou ainda consumidos pelo governo. As famílias têm acesso ao mercado de bens e de ativos financeiros como moeda, depósitos bancários, crédito e títulos públicos.

Os bancos intermedeiam recursos financeiros entre a família, firmas, empreendedores e governo, mas esses agentes diferem na maneira como utilizam o sistema bancário. Enquanto a família aloca sua poupança em moeda, depósitos bancários, ações dos bancos e títulos públicos, firmas e empreendedores demandam crédito para financiar folha de salários e adquirir bens para investimento, respectivamente. Os bancos têm acesso ao mercado interbancário, de títulos públicos emitidos pelo governo. O governo é dotado de autoridade monetária e fiscal sobre a economia.

Ao todo a economia descreve onze mercados: i) bens finais; ii) bens intermediários; iii) trabalho; iv) capital (aluguel); v) capital (compra); vi) moeda; vii) depósitos bancários; viii) títulos públicos; ix) crédito; x) crédito intermediário; xi) redesconto. 
As fricções impostas ao modelo incluem rigidezes reais e nominais sobre a economia, seguindo o mainstream da literatura, mas acrescentando fricções financeiras específicas ao mercado bancário: i) persistência no hábito; ii) utilidade de manter ativos como moeda, depósitos e títulos por razões transacionais; iii) demanda por crédito das famílias em financiamento de longo prazo; iv) rigidez de preços do bem final a la Calvo (1983); v) custos fixos na produção de bens; vi) custos de ajustamento do investimento; vii) contrato financeiro de crédito; viii) tecnologia bancária de produção; ix) custos operacionais do banco; e x) liquidez do sistema de pagamentos. A manutenção das fricções reais em detrimento da parcimônia é uma escolha de modelagem que permite a comparação com os textos mais recentes da literatura. A comparação entre textos é o que permite analisar como as fricções bancárias interagem com as fricções tradicionais, além de garantir o controle dos efeitos específicos do mercado financeiros sobre os agregados econômicos.

\subsubsection{Famílias}

Existe uma família representativa na economia, composta por infinitos indivíduos de preferências idênticas e uniformemente distribuídos no intervalo [0,1]. A família vive infinitamente e decide em cada período o consumo de bem final e as horas dedicadas ao trabalho. A família tem uma unidade de tempo disponível para alocar entre trabalho e lazer. Suponha que a utilidade da família possa ser descrita por uma função $U: \mathbb{R}^{4} \rightarrow \mathbb{R}$. O valor esperado do fluxo intertemporal descontado de utilidade da família em $t=0$ é dado por:

$$
E_{0} \sum_{t=0}^{\infty} \beta^{t} U\left(C_{t}-b C_{t-1} ; H_{t} ; M_{t} / P_{t} ; D_{t} ; B_{t}\right)
$$

sendo $E_{t}$ a esperança matemática condicional no conjunto de informação disponível em $t, \beta \in$ $(0,1)$ é o fator de desconto intertemporal subjetivo, $C_{t} \geq 0$ é o consumo real de bens finais no período $t, H_{t} \in[0,1]$ é o número de horas dedicadas ao trabalho. $M_{t}$ é a quantidade de moeda que gera ganhos por facilitar transações, $D_{t}$ são os depósitos bancários e $B_{t}$ são títulos públicos. $P_{t}$ é o índice agregado de preços. Assume-se bom comportamento da função utilidade, que deve ser estritamente crescente no consumo, estritamente decrescente no trabalho, estritamente 
crescente nos ativos moeda, depósitos e títulos e estritamente côncava.

Em termos gerais, a posse de ativos admite ganhos de utilidade porque facilitam as transações da economia, em relação ao ativo livre de risco, como normalmente é posto em modelos mais simples nos quais a moeda é o único ativo financeiro. Apenas por formalidade, admite-se que moeda, depósitos bancários e títulos públicos tem ganhos transacionais intrínsecos na posse em relação ao ativo livre de risco $A_{t}$. Em termos práticos, nenhum ganho transacional é atribuído aos títulos públicos em relação ao ativo livre de risco, o que garante, em equilíbrio, a igualdade das taxas de juros.

A decisão de consumo é tomada pela família. Todos os indivíduos, que são membros atomísticos da família representativa, são idênticos e estão indexados por $j \in[0,1]$. Uma vez que os indivíduos são idênticos, eles consomem bens finais de forma igual. Assim, $c_{t}^{j}=c_{t}, \forall j \mathrm{e}$ $c_{t}=C_{t}$, porque os consumidores estão indexados num intervalo contínuo de medida unitária.

Há a formação de hábito no consumo como fricção real, a medida de persistência é o parâmetro $b \in[0,1)$. A família consome um único bem final, que é um composto produzido por um contínuo de bens intermediários diferenciáveis $c_{i t}$ e cada variedade é produzida por uma firma indexada por $i \in[0,1]$. O consumo total segundo o agregador Dixit-Stiglitz é:

$$
c_{t}=\left[\int_{0}^{1} c_{i t}^{1-\frac{1}{\eta}} d i\right]^{1 /\left(1-\frac{1}{\eta}\right)}
$$

no qual $\eta$ é a elasticidade de substituição intratemporal entre as diversas variedades de bens diferenciáveis. Para um dado nível de consumo do bem composto, o indivíduo consumidor demanda cada tipo de bem intermediário $i \in[0,1]$, no período $t$, de tal sorte que a compra das variedades de bens intermediários deve resolver o problema de minimização do dispêndio, cuja condição de primeira ordem gera a seguinte função demanda por bens intermediários:

$$
c_{i t}=c_{t}\left(\frac{P_{i t}}{P_{t}}\right)^{-\eta}
$$


sendo $P_{i t}$ o preço do bem intermediário $C_{i t}$. O preço do bem composto é aquele que torna o indivíduo indiferente entre comprar o bem composto ou comprar cada um dos bens intermediários, para uma dada utilidade. O índice nominal de preços da economia é o agregador de preços Dixit-Stiglitz:

$$
P_{t}=\left[\int_{0}^{1} P_{i t}^{1-\eta} d i\right]^{1 /(1-\eta)}
$$

O mercado de trabalho é assumido perfeitamente competitivo. A decisão de trabalho é também tomada no nível da família e todos os indivíduos ofertam a mesma quantidade de horas de trabalho. A oferta de trabalho agregada será $H_{t}=\int_{0}^{1} h_{t}^{j} d j$. Novamente os indivíduos se comportam de forma igual e $h_{t}^{j}=h_{t}$ e $h_{t}=H_{t}$.

A família escolhe entre diversos ativos para a alocação da sua renda não consumida ${ }^{1}$ : moeda, títulos públicos, depósitos bancários e ativos livres de risco. A moeda é um título emitido pelo governo e que não paga juros. Títulos públicos $B_{t}$ são emitidos pelo governo e comprados pelas famílias e pelos bancos, remunerando à taxa bruta de juros reais $R_{t}^{b} \geq 1$ de um período. Depósitos bancários são títulos emitidos pelos bancos e comprados pelas famílias e que remuneram à taxa bruta de juros reais sobre depósitos $R_{t}^{d} \geq 1$ de um período. A taxa bruta de juros reais do ativo livre de risco $A_{t}$ de um período é $R_{t} \geq 1$. Na posse de moeda, depósitos bancários e títulos públicos, as famílias percebem ganhos transacionais intrínsecos e específicos a cada um desses ativos. Ganhos de utilidade justificam a escolha de ativos dominados em retorno e são explicados pela facilitação de transações de compra de bens finais. Essa especificação é comum e usada justificar taxas de juros diferentes para os diversos ativos, como em Canzoneri et al. (2008).

Para incluir crédito na família na abordagem do agente representativo, assume-se que as famílias tomam a cada período uma quantidade fixa exógena de crédito $L_{t}^{j}=\bar{L}^{j}$, pagando ao banco

\footnotetext{
${ }^{1}$ Existe capital na economia, mas é vedada a hipótese de armazenamento porque as famílias não dominam a tecnologia de reprodução, exclusiva dos produtores de capital.
} 
a taxa bruta de juros $R_{t}^{l(j)}$. Usualmente modelagens do tipo são explicadas pela existência de serviços de aluguel ou hospedagem consumidos ininterruptamente que requerem financiamento bancário. Aqui o mecanismo é proposto com a finalidade de permitir a abstração de que parte do crédito total da economia não está relacionada com a produção de bens.

A família recebe no início do período transferências do tipo lump-sum $V_{t}^{f i r}, V_{t}^{\text {emp }}, V_{t}^{\text {ban }}, T_{t}$ respectivamente referentes a: i) a fração dos lucros correntes aferidos pelas firmas em competição monopolística e sob rigidez de preços; ii) a riqueza líquida da fração de empreendedores que não sobrevivem; iii) a fração do capital bancário liquidado e de lucros líquidos não incorporados; e iv) as transferências do governo. A restrição orçamentária da família é dada pela equação:

$$
\begin{aligned}
C_{t}+D_{t}+\frac{M_{t}}{P_{t}}+B_{t}+A_{t}+R_{t-1}^{l(j)} \bar{L}^{j}= & \left(1-\tau_{t}^{h}\right) W_{t} H_{t}+\bar{L}^{j} \\
& +R_{t-1}^{d} D_{t-1}+R_{t-1}^{b} B_{t-1}+R_{t-1} A_{t-1}+\frac{M_{t-1}}{P_{t}} \\
& +V_{t}^{f i r}+V_{t}^{\text {emp }}+V_{t}^{\text {ban }}+T_{t}
\end{aligned}
$$

O problema da família é maximizar a utilidade intertemporal (2.1) descontada no tempo, sujeito à restrição orçamentária (2.5) e $L_{t}^{j}=\bar{L}^{j}$. O problema está descrito no apêndice (A). As condições de ótimo para a família podem ser interpretadas em relação à utilidade do consumo de bens:

$$
\begin{aligned}
\frac{U_{C_{t}}-\beta b U_{C_{t+1}}}{U_{C_{t+1}}-\beta b U_{C_{t+2}}}=\beta R_{t} \\
\frac{-U_{H_{t}}}{U_{C_{t}}-\beta b U_{C_{t+1}}}=W_{t}\left(1-\tau_{t}^{h}\right) \\
\frac{U_{M_{t} / P_{t}}}{U_{C_{t}}-\beta b U_{C_{t+1}}}=\frac{R_{t}-E_{t}\left(1 / \pi_{t+1}\right)}{R_{t}}, \quad R_{t}>E_{t}\left(1 / \pi_{t+1}\right) \\
\frac{U_{D_{t}}}{U_{C_{t}}-\beta b U_{C_{t+1}}}=\frac{R_{t}-R_{t}^{d}}{R_{t}}, \quad R_{t}>R_{t}^{d} \\
\frac{U_{B_{t}}}{U_{C_{t}}-\beta b U_{C_{t+1}}}=\frac{R_{t}-R_{t}^{b}}{R_{t}}, \quad R_{t}>R_{t}^{b}
\end{aligned}
$$


A relação intertemporal ótima de substituição do consumo é conhecida como equação de Euler (2.6). O custo marginal líquido de uma unidade de consumo, em termos de utilidade, deverá ser igual ao ganho líquido de postergar essa unidade de consumo. Adiar o consumo corrente significa acumulação de ativos correntes, percebendo retorno no período seguinte. A razão de troca intertemporal de consumo entre dois períodos subsequentes deve ser igual à razão do ganho líquido de transferir o consumo para o período seguinte.

A decisão de trabalho (2.7) obedece ao critério de dispensar lazer até que a hora marginal valha, em termos de utilidade marginal de consumo, o valor do salário real líquido de impostos. Também existe trade-off entre consumo de bens e de moeda. O indivíduo troca bens por moeda até o ponto em que o custo de oportunidade de reter saldos monetários reais for igual ao benefício marginal da moeda, em termos de utilidade, segundo equação (2.8). De forma similar, as demandas por depósitos bancários (2.9) e títulos públicos (2.10) explicam a aquisição de ativos dominados em retorno pela percepção de ganhos de utilidade até o ponto em que equivalham ao custo de oportunidade do ativo. Em equilíbrio geral, a taxa de juros dos títulos públicos será igual à taxa livre de risco porque não será modelada qualquer razão de risco para o governo.

\subsubsection{Firmas}

O bem final é um composto de bens intermediários produzidos por firmas diferentes. Cada variedade de bem intermediário é produzido por uma única firma em concorrência monopolística. Existem infinitas firmas distribuídas uniformemente no intervalo unitário. Cada firma $i \in[0,1]$ produz utilizando como insumos capital $k_{t}^{d}$ e trabalho $h_{t}^{d}$. No mercado de fatores, o capital demandado pela firma é um composto homogêneo do capital ofertado por cada empreendedor, bem como o trabalho demandado é um composto homogêneo do trabalho ofertado por cada indivíduo dentro da família. A tecnologia de produção da firma $i$ é definida assim:

$$
z_{t} F\left(k_{i t}^{d}, h_{i t}^{d}\right)-\psi
$$


onde $F$ é a função de produção, assumida homogênea de grau um, côncava e estritamente crescente em ambos os argumentos. O parâmetro $\psi$ mede o custo fixo de operação da firma em cada período, o que implica que a função de produção possui retornos crescentes de escala. Essa tecnologia de produção segue Schmitt-Grohé \& Uribe (2005) e os custos fixos pagos a cada período são importantes para calibrar a razão lucro/produto em estado estacionário tal que seja consistente com os dados. A variável $z_{t}$ é um choque agregado estocástico na produtividade total e cuja lei de movimento é dada por:

$$
\ln z_{t}=\rho_{(z)} \ln z_{t-1}+\epsilon_{t}^{z}
$$

sendo parâmetros $\rho_{(z)}$, que é a persistência do choque, e $\epsilon_{t}^{z}$, que representa uma inovação i.i.d. com média zero e variância $\sigma_{\epsilon^{z}}^{2}$.

A demanda por crédito nas firmas é normalmente motivada pela necessidade de pagar de forma antecipada parte dos custos de fatores, como em Diaz-Gimenez et al. (1992), Christiano, Eichenbaum \& Evans (2005), Schmitt-Grohé \& Uribe (2005). Aqui a firma precisa pagar antecipadamente parte da sua folha de salários e, portanto, necessita de tomar recursos junto ao mercado bancário para viabilizar a operação. O aluguel do capital, ao contrário, pode ser pago após a operação produtiva. A demanda de crédito da firma $i$, em termos reais, é dada por:

$$
l_{t}^{d}=\nu W_{t} h_{t}^{d}
$$

em que $\nu \in[0,1]$ denota a fração da folha de salários que precisa ser financiada. Seguindo as seções anteriores, como o crédito é assumido um produto não homogêneo, a demanda de crédito $l_{t}^{d}$ da firma é um composto de diversos créditos tomados junto a cada banco $b$ do mercado, indexados no intervalo $b \in[0,1]$ segundo o agregador Dixit-Stiglitz. A demanda de crédito da firma $i$ para o banco $b$ será, portanto:

$$
l_{b, t}^{d}=l_{t}^{d}\left(\frac{R_{b, t}^{l}}{R_{t}^{l}}\right)^{-\vartheta}
$$


Para uma dada demanda agregada $Y_{t}$ pelo bem final, a demanda agregada pelo bem intermediário produzido pela firma $i$ é dada por:

$$
y_{t}=\left(\frac{P_{i, t}}{P_{t}}\right)^{-\eta} Y_{t}
$$

O lucro das firmas é transferido de forma lump-sum para novos empreendedores e família, nas frações $\iota$ e $1-\iota$, respectivamente. A expressão para o lucro corrente da firma monopolista, em termos nominais, é:

$$
P_{t} \Pi_{t}=P_{i, t}\left(\frac{P_{i, t}}{P_{t}}\right)^{-\eta} Y_{t}-P_{t}\left(R_{t}^{k}-1\right) k_{t}^{d}-P_{t} W_{t} h_{t}^{d}+P_{t}\left(l_{t}^{d}-\int_{0}^{1} R_{b, t}^{l} l_{b, t}^{d} d b\right)
$$

Como em Schmitt-Grohé \& Uribe (2005), assume-se que a oferta de bem intermediário da firma $i$ deve sempre satisfazer a demanda pelo bem intermediário ao preço vigente. Dessa forma a firma monopolista deve operar com:

$$
z_{t} F\left(k_{t}^{d}, h_{t}^{d}\right)-\psi \geq\left(\frac{P_{i, t}}{P_{t}}\right)^{-\eta} Y_{t}
$$

O problema da firma em concorrência monopolista é maximizar seu lucro operacional em $t$, equação (2.16), sujeito à restrição de atendimento à demanda do bem intermediário (2.17) e está detalhado no apêndice (A). O multiplicador de Lagrange da restrição de demanda é interpretado como o custo marginal real $\Omega_{t}$ de produção do bem pela firma. As condições de primeira ordem associadas aos fatores capital e trabalho são:

$$
\begin{aligned}
\left(R_{t}^{k}-1\right) & =\Omega_{t} z_{t} F_{k}\left(k_{t}^{d}, h_{t}^{d}\right) \\
W_{t} & =\Omega_{t} \frac{z_{t} F_{h}\left(k_{t}^{d}, h_{t}^{d}\right)}{1+\nu\left(\int_{0}^{1} R_{b, t}^{l}\left(\frac{R_{b, t}^{l}}{R_{t}^{l}}\right)^{-\vartheta} d b-1\right)}
\end{aligned}
$$

Os preços são assumidos rígidos a la Calvo (1983). A cada período, uma fração $\alpha_{f}$ das firmas 
aleatoriamente distribuídas no intervalo unitário não pode otimizar seu preço. Essas firmas então fazem a correção do preço anterior pela inflação passada, com certo grau de indexação $\chi_{f} \in[0,1]:$

$$
P_{i, t}=P_{i, t-1} \pi_{t-1}^{\chi_{f}}
$$

A fração $\left(1-\alpha_{f}\right)$ das firmas escolhe o preço vigente de forma ótima. Essas firmas estão diante de um problema de maximização intertemporal do valor presente esperado dos seus lucros futuros, descontado à taxa de juros livre de risco. Seja $\tilde{P}_{t}$ o preço ótimo para a firma que maximiza em $t$. Seja $r_{t, t+j}$ o fator de desconto intertemporal definido pela taxa bruta de juros livre de risco:

$$
r_{t, t+j}=\prod_{s=1}^{j} \frac{1}{R_{t+s-1}}
$$

Quando a firma pode alterar o preço, deve escolher $\tilde{P}_{t}$ de forma ótima, considerando que pode manter esse preço rígido por infinitos períodos. O problema da firma sob rigidez de preços é detalhado no apêndice, seção (A). A condição de primeira ordem para a firma definir seu preço ótimo é dada pela equação (2.22). A expressão ${ }^{2}$ explica que o preço ótimo escolhido pelas firmas quando podem otimizar é aquele que garante receitas marginais médias esperadas que equalizam os custos marginais médios esperados.

$$
E_{t} \sum_{s=0}^{\infty} r_{t+s} \alpha_{f}^{s} P_{t+s}\left(\frac{\tilde{P}_{t}}{P_{t}}\right)^{-\eta} \prod_{k=1}^{s}\left(\frac{\pi_{t+k-1}^{\chi_{f}}}{\pi_{t+k}}\right)^{-\eta} Y_{t+s}\left[\frac{\eta-1}{\eta}\left(\frac{\tilde{P}_{t}}{P_{t}}\right) \prod_{k=1}^{s}\left(\frac{\pi_{t+k-1}^{\chi_{f}}}{\pi_{t+k}}\right)-\Omega_{i, t+s}\right]=0
$$

A rigidez de preços altera o equilíbrio da economia tanto nas quantidades como nos preços e é diretamente responsável pela existência de lucro econômico de longo prazo no contexto

\footnotetext{
${ }^{2} \mathrm{~A}$ condição de primeira ordem no formato original requer uma formulação recursiva para viabilizar as simulações computacionais e esse tratamento segue como normalmente é feito nos blocos de rigidezes de preços e salários dos modelos DSGE. As transformações constam do apêndice.
} 
da estrutura de concorrência monopolística. Os resultados da agregação estão no apêndice (A) e mostram como se comportam quantidades e lucros de acordo com o nível de rigidez da economia.

\subsubsection{Produtores de Capital}

Há na economia agentes únicos especializados na reprodução de capital físico instalado, mediante o investimento em bens finais. Os produtores de capital detém a tecnologia de transformação de bens finais em capital físico novo e são unidades apenas produtoras que não consomem e nem trabalham.

No início de cada unidade de tempo, os produtores de capital compram dos empreendedores o estoque de capital disponível e compram das firmas bens finais com o objetivo de investimento. O novo estoque de capital físico é vendido aos empreendedores. A propriedade do capital muda entre produtores de capital e empreendedores, portanto. As firmas, contudo, detêm a posse mediante o pagamento de aluguel sobre o estoque alugado. A abstração representada pelos produtores de capital é uma estratégia de modelagem para criar um sistema de preço de mercado para o estoque de capital, cujo objetivo essencial é garantir liquidez da riqueza dos empreendedores. Isso porque não somente a renda do aluguel, mas também o estoque de capital, são utilizados como colateral dos empréstimos bancários.

Assume-se que existem infinitas unidades produtoras de capital idênticas e uniformemente distribuídas no intervalo unitário, neutras a risco e que operam em competição perfeita. Assumese também que o capital físico é um bem homogêneo. A taxa marginal de transformação do estoque antigo, após depreciação, para o novo estoque de capital físico instalado é unitária. Existem custos de ajustamento na transformação dos bens finais em capital físico, que acrescentam dinâmica ao problema do produtor. Seja $i_{t}$ a quantidade de bens finais adquirido pela firma produtora de capital ao preço $P_{t}$ por unidade de bem final. $\mathrm{O}$ estoque de capital segue a 
seguinte lei de movimento:

$$
k_{t+1}=x_{t}+i_{t}\left[1-\mathcal{S}\left(\frac{i_{t}}{i_{t-1}}\right)\right]
$$

onde $x_{t}$ é o estoque corrente depreciado de capital físico. $\mathcal{S}$ é uma função que determina os custos de ajustamento do investimento sobre o agregado de bens finais. A função satisfaz $\mathcal{S}(1)=\mathcal{S}^{\prime}(1)=0$ e $\mathcal{S}^{\prime \prime}(1)>0$, que garantem a ausência de custos de ajustamento de primeira ordem na vizinhança do estado estacionário.

O investimento realizado em termos de bens finais pelo empreendedor segue a função de agregação Dixit-Stiglitz para definir a demanda pelos bens intermediários para a firma $i$ :

$$
i_{i t}=i_{t}\left(\frac{P_{i t}}{P_{t}}\right)^{-\eta}
$$

onde $P_{i t}$ é o preço do bem intermediário $i_{i t}$.

Seja $\tilde{Q}_{t}$ o preço pago por cada unidade de capital em $t$. No mesmo período, o produtor de capital paga $P_{t} i_{t}$ pelos bens finais, compra o estoque de capital corrente dos empreendedores, gerando o novo capital $x_{t+1}$ e o revende aos empreendedores. O produtor de capital resolve o problema dinâmico (apêndice A) de maximizar o lucro obtido com a reprodução do capital físico, escolhendo a sequência de bens finais comprados com o objetivo de investimento em cada período. $\mathrm{O}$ fator de desconto intertemporal é a taxa de juros livre de risco, como definido em (2.21).

$$
Q_{t}\left[1-\mathcal{S}_{t}-\frac{i_{t}}{i_{t-1}} \mathcal{S}_{t}^{\prime}\right]+E_{t} r_{t, t+1} Q_{t+1}\left(\frac{i_{t+1}}{i_{t}}\right)^{2} \mathcal{S}_{t+1}^{\prime}=1
$$

A condição de ótimo (2.25) guarda semelhança com a equação dinâmica que advém do mesmo problema em Christiano, Eichenbaum \& Evans (2005), Smets \& Wouters (2003) e Christiano, Motto \& Rostagno (2007). A interpretação é simples: o produtor de capital demanda bens finais para investimento até o ponto em que os ganhos marginais reais sejam iguais ao custo marginal 
do bem, normalizado em 1. Qualquer valor do estoque de capital comprado pelos produtores é consistente com a maximização intertemporal. A agregação não apresenta dificuldades nem interpretações adicionais.

\subsubsection{Empreendedores}

A propriedade do capital é relevante no modelo para simular duas características: i) firmas precisam alugar capital para produzir; ii) empreendedores precisam tomar empréstimos para comprar capital $^{3}$ e repassá-lo às firmas. Os empreendedores podem ser interpretados como uma abstração da capacidade investidora das firmas.

Empreendedores são agentes com habilidade para empregar o capital físico instalado. São aqui entendidos como extensões das firmas e têm natureza exclusivamente empresarial: são intermediários, não consomem e nem trabalham ${ }^{4}$. Esses agentes econômicos são únicos na economia com a capacidade de propor projetos de uso do capital físico instalado. Um projeto de investimento do empreendedor tem duração de um período e significa: i) coletar recursos próprios e celebrar empréstimos bancários; ii) comprar o capital físico instalado dos produtores de capital; iii) alugar o capital às firmas; e iv) aferir receitas de aluguéis e quitar o contrato financeiro, conhecendo a sua riqueza líquida.

Os empreendedores são idênticos, neutros a risco, mas possuem riqueza líquida diferente decorrente do processo estocástico de acumulação. Cada empreendedor tem horizonte de vida finito: a cada período um empreendedor qualquer tem a probabilidade constante $\gamma$ de sobreviver até o período seguinte ${ }^{5}$. Essa característica simula o fenômeno de entrada e saída de

\footnotetext{
${ }^{3}$ A operação de compra de capital dos empreendedores simula características da economia real, forçando que as firmas tenham que se refinanciar integralmente a cada período, segundo Bernanke, Gertler \& Gilchrist (1999). Impor que o empreendedor deve recomprar todo o estoque de capital em cada período é uma hipótese de modelagem para mimetizar as restrições financeiras percebidas pelas firmas em todas as suas operações, não apenas no investimento marginal. Alencar \& Nakane (2004) e Fuerst (1995) modelam essa fricção financeira apenas para o investimento intraperíodo. O efeito absoluto do acelerador financeiro, que se associa ao volume de crédito tomado pelos empreendedores, seria minimizado com essa alternativa de modelagem.

${ }^{4}$ Ao contrário, nos modelos de Bernanke, Gertler \& Gilchrist (1999) e Alencar \& Nakane (2004), o empreendedor tem comportamento empresarial e consumidor, pois ofertam trabalho, intermedeiam capital e consomem.

${ }^{5} \mathrm{~A}$ probabilidade de sobrevivência constante em cada $t$ e independente da idade do empreendedor facilita a
} 
projetos de investimento e de firmas do mercado, além de ser conveniente para garantir que esse setor empresarial não conseguirá acumular riqueza suficiente para seu financiamento próprio, conforme argumentam Bernanke, Gertler \& Gilchrist (1999). Como usual na literatura, por simplicidade, assume-se que nascem tantos empreendedores quanto desaparecem e esses novos empreendedores têm inicialmente riqueza zero. $(1-\gamma)$ pode ser interpretada como a fração de projetos fracassados.

Em cada instante $t$, empreendedores vivos propõem projetos de uso do capital. Para comprar o capital físico dos produtores de capital, os empreendedores utilizam recursos próprios (riqueza líquida, $n_{t}$ ) e crédito bancário $l_{t}^{d}$. A riqueza líquida é um elemento crucial para determinar a demanda de crédito da economia e o custo do financiamento externo, portanto. Níveis elevados de riqueza líquida ${ }^{6}$ aumentam a capacidade de financiamento próprio do empreendimento e reduzem a tomada de dívida com o setor bancário. Assume-se que os bancos oferecem contratos financeiros de dívida em $t$ que devem ser quitados no início do período $t+1$. A taxa bruta de juros reais do empréstimo é $R_{e, t}^{l}$.

\section{Demanda de Crédito do Empreendedor}

Os empreendedores que detém capital físico alugam seu estoque às firmas à taxa bruta $R_{t}^{k}$ por unidade de capital utilizado. A renda do capital para cada investidor é sensível tanto a choques idiossincráticos quanto a choques agregados e, apenas depois de celebrado o contrato financeiro, cada empreendedor conhecerá o choque idiossincrático. Em um mundo sem incerteza, a renda líquida do aluguel do capital percebida por cada empreendedor no período será, em unidades de capital físico, $\left(R_{t}^{k}-1\right) k_{t}$. Somando o estoque de capital alugado após a depreciação, no período seguinte o empreendedor tem $x_{t}=\left[\left(1-\tau_{t}^{k}\right)\left(R_{t}^{k}-1\right)+(1-\delta)\right] k_{t}$ unidades de capital físico, líquido de imposto sobre o capital $\tau_{t}^{k}$. Porém, o retorno para o empreendedor $e$

agregação. ${ }^{6}$ Alternativamente, pode-se entender que os empreendedores financiam externamente toda a compra do capital
junto aos bancos e a riqueza líquida funciona como colateral do empréstimo. 
em unidades do capital é $\kappa x_{t}$, onde $\kappa$ é a perturbação idiossincrática para o empreendedor $e$.

A variável aleatória $\kappa$ é um processo estocástico i.i.d. no tempo e entre empreendedores, cuja função distribuição acumulada de probabilidade $\Phi(\kappa)$ é contínua e diferenciável e possui suporte não negativo, com $E(\kappa)=1$. A função densidade de probabilidade é definida por $\phi(\kappa)$, é estritamente positiva e continuamente diferenciável no intervalo do suporte e ambas as funções são de conhecimento comum de todos os agentes.

No início do período $t$, cada empreendedor apura sua riqueza líquida $n_{t}$ ao preço $Q_{t}$, que advém da venda do seu estoque de capital físico aos produtores de capital menos os custos com financiamento externo do período anterior.

$$
n_{t}=\kappa Q_{t} x_{t-1}-R_{t-1}^{l} l_{t-1}^{d}
$$

A fração $\gamma$ de novos empreendedores que nasce no início de cada período recebe, de forma lump-sum, a transferência $F_{t}^{f i r}$ de parte dos lucros líquidos das firmas em concorrência monopolística.

A diferença $l_{t}^{d}$ entre o valor do estoque de capital físico e a riqueza líquida de cada empreendedor deve ser financiada junto aos bancos:

$$
l_{t}^{d}=Q_{t} k_{t}-n_{t}
$$

O projeto de uso do capital do empreendedor é factível se o retorno $\kappa Q_{t+1} x_{t+1}$ obtido pelo projeto for suficiente para quitar o contrato de empréstimo, em cada período. O empreendedor assina o contrato financeiro quando é possível quitá-lo no período seguinte. O empreendedor estará solvente ex-post se $E_{t} n_{t+1} \geq 0 \quad \therefore \quad \kappa E_{t} Q_{t+1} x_{t} \geq R_{t}^{l} l_{t}^{d}$. Por consequência, existe um threshold $\bar{\kappa}$ para o empreendedor $e$, tal que satisfaz a condição de solvência com igualdade. 
Seja esse threshold o nível crítico de solvência (2.28) do projeto:

$$
\bar{\kappa}=\frac{R_{t}^{l} l_{t}^{d}}{E_{t} Q_{t+1} x_{t}}
$$

O aumento dos juros sobre empréstimos $R_{t}^{l}$ implica no aumento do nível crítico de solvência do empreendedor, tudo o mais constante. Isso porque quanto maior o custo de intermediação cobrado pelo banco para aceitar o contrato financeiro, maior deve ser o retorno para que o projeto se mantenha viável. Nesse caso, o empreendedor precisará de um choque idiossincrático mais favorável para conseguir honrar sua dívida no período seguinte. Com juros mais altos, o domínio de $\kappa$ que gera insolvência $[0, \bar{\kappa})$ aumenta e a probabilidade de default cresce. Por outro lado, quanto maior for a necessidade de financiamento externo do empreendedor $l_{t}^{d}$ maior será seu nível crítico de solvência ${ }^{7}$ e a sua possibilidade de falência.

O contrato financeiro que cada empreendedor celebra com o banco é determinado pelo vetor $\left(\bar{\kappa}, R_{t}^{l}, l_{t}^{d}\right)$ : nível crítico de solvência do projeto, taxa de juros idiossincrática de intermediação financeira e demanda de crédito.

\section{Crédito Não Homogêneo e Poder de Mercado}

O crédito não é um produto homogêneo. A diferenciação de produtos acrescenta poder de mercado aos bancos, isso porque se o banco ofertar crédito a um preço acima da média da indústria ainda haverá demanda para seu produto. Cada empreendedor demanda o volume $l_{t}^{d}$ de crédito, que é um composto de diversos créditos tomados com cada banco $b$ do mercado,

\footnotetext{
${ }^{7}$ As hipóteses sobre a função distribuição são fundamentais para excluir equilíbrios com racionamento de crédito, conforme mostram Bernanke, Gertler \& Gilchrist (1999), apêndice A. Mesmo se os juros sobre empréstimos forem suficientemente altos, solicitando níveis de solvência mais elevados dos empreendedores, sempre existe $\bar{\kappa}$ com alguma probabilidade não nula. Então os equilíbrios com racionamento de crédito estão desconsiderados no modelo.
} 
indexados no intervalo $b \in[0,1]$ segundo o agregador Dixit-Stiglitz:

$$
l_{t}^{d}=\left[\int_{0}^{1} l_{b, t}^{1-\frac{1}{\vartheta}} d b\right]^{1 /\left(1-\frac{1}{\vartheta}\right)}
$$

e $\vartheta$ é o grau de diferenciação do crédito entre os bancos. Para um dado nível de volume de crédito demandado, o empreendedor demanda crédito do banco $b$ de tal forma a minimizar seu custo $\int_{0}^{1} R_{b, t+1}^{l} l_{b, t} d b$ sujeito à equação (2.29). A demanda de crédito ao banco $b$ pelo empreendedor será, portanto:

$$
l_{b, t}=l_{t}^{d}\left(\frac{R_{b, t}^{l}}{R_{t}^{l}}\right)^{-\vartheta} .
$$

A taxa bruta de juros média da indústria é definida como o preço que torna indiferente contratar o crédito como um bem composto ou contratar separadamente cada produto, para um dado volume de demanda por empréstimo:

$$
R_{t}^{l}=\left[\int_{0}^{1} R_{b, t}^{l}{ }^{1-\vartheta} d b\right]^{1 /(1-\vartheta)}
$$

\section{Assimetria Informacional}

Existe assimetria de informação do tipo ex-post no contrato financeiro. O empreendedor observa privadamente seu resultado $\kappa$ e nenhuma outra classe de agentes conhece essa informação. Assume-se que a instituição financeira dispõe de um mecanismo custoso de verificação que permite conhecer exatamente a realização do empreendedor. Seja $V: \mathbb{R}_{+} \rightarrow \mathbb{R}_{+}$o custo de verificação e tome $V(a)=\mu a$, em que $a$ é a renda a ser verificada.

Duas possibilidades podem ser verificadas no início do período para cada empreendedor com nível crítico de solvência $\kappa$ :

1. Se o empreendedor realiza $\kappa \geq \bar{\kappa}$, sua riqueza líquida é $\kappa Q_{t+1} x_{t}-R_{t}^{l} l_{t}^{d}$. Cada banco recebe o pagamento de capital mais juros $R_{b, t}^{l} l_{b, t}^{d}$. Nesse caso, a renda líquida obtida 
com o aluguel do capital foi suficiente para quitar o empréstimo bancário.

2. Se o empreendedor realiza $\kappa<\bar{\kappa}$, ele não terá recursos para quitar sua dívida e declarará falência. O banco é compelido a verificar a riqueza, incorrendo no custo de verificação $V(a)$ para conhecer o retorno específico do empreendedor. O banco transfere para si toda a riqueza residual do empreendedor e encerra o contrato. O empreendedor falido tem riqueza líquida zero e a receita líquida de cada banco nesse caso é $(\kappa-\mu) Q_{t+1} x_{t}$.

O retorno bruto esperado do banco $b$ com o contrato financeiro de empréstimo de recursos para o empreendedor é dado, em termos reais, pela equação (2.32). O primeiro termo é a receita do banco em caso de falência do empreendedor, quando cada banco recebe o valor esperado da renda de aluguel do capital e incorre no custo de verificação proporcional à renda verificável. Já o segundo termo é a receita do banco quando o empreendedor é adimplente e o contrato financeiro é quitado em $t+1$.

$$
\begin{aligned}
E_{t} r_{t, t+1} \Pi_{b, t+1}=( & -\gamma) E_{t} r_{t, t+1}\left\{\int_{0}^{\bar{\kappa}}\left[\kappa E_{t} Q_{t+1} x_{t}-V(.)\right] d \Phi(\kappa) E_{t}\left(\frac{R_{b, t}^{l}}{R_{t}^{l}}\right)^{-\vartheta}\right. \\
& \left.+[1-\Phi(\bar{\kappa})] R_{b, t}^{l} l_{b, t}\right\}
\end{aligned}
$$

\section{Contrato Financeiro do Investimento}

Cada banco oferece um contrato financeiro $\left(\bar{\kappa}, R_{b, t}^{l}, l_{b, t}\right)$ ao empreendedor, tal que o seu retorno esperado $E_{t} \Pi_{b, t+1}$ seja pelo menos tão bom quanto o custo de oportunidade de emprestar o mesmo volume de recursos em um mercado de características iguais, mas livre do risco idiossincrático. Seja $Z_{t}$ essa taxa bruta de juros de um período nesse mercado de crédito adjacente. O problema do banco será desenvolvido na seção 2.1.5. O contrato financeiro de investimento é realizado período a período entre empreendedor e banco. O apêndice (A) contém detalhes.

Em equilíbrio parcial, os bancos oferecem o mesmo contrato financeiro para um dado empreendedor. A taxa de juros individual é a taxa de juros que o banco consegue no empréstimo em 
outro mercado (outside option) mais um prêmio de risco específico do projeto:

$$
\begin{aligned}
R_{t}^{l} & =\tilde{s}(\bar{\kappa}) Z_{t} \\
\tilde{s}(\bar{\kappa}) & =\frac{\bar{\kappa}}{(1-\gamma)\{[1-\Phi(\bar{\kappa})] \bar{\kappa}+(1-\mu) \mathcal{H}(\bar{\kappa})\}}
\end{aligned}
$$

onde $\tilde{s}(\bar{\kappa})$ é a função prêmio de risco esperado $\tilde{s}: \mathbb{R} \rightarrow \mathbb{R}$, definida para $\kappa>0$ e $\mathcal{H}(x)=$ $\int_{0}^{x} \kappa \psi(\kappa) d \kappa=E[\kappa \mid \kappa>x] P[\kappa>x]$.

O nível crítico de solvência é informação suficiente para precificar o prêmio de risco do contrato financeiro. Existem dois efeitos contrários atuando quando o nível de solvência muda. Um aumento em $\bar{\kappa}$ aumenta o retorno do banco em caso de quitação do contrato. Mas, por outro lado, esse aumento também significa maior probabilidade de default.

As condições de existência de equilíbrio com solução interior para o crédito estão relacionadas essencialmente ao spread entre a taxa de juros do aluguel do capital e a taxa de juros do crédito ao empreendedor. Em caso de existência o nível crítico de solvência é único $\left(\bar{\kappa}^{*}\right)$ e igual para todos os empreendedores, independente do volume do estoque de capital ou da riqueza líquida. O nível crítico de solvência determina o nível de alavancagem dos empreendedores. Defina a função $v: \mathbb{R} \rightarrow \mathbb{R}$, válida para $\kappa \geq 0$, como o nível de financiamento externo do empreendedor $^{8}$, ou seja, a relação entre o estoque de capital e a demanda por crédito. De acordo com as equações de equilíbrio:

$$
v(\bar{\kappa})=\frac{l_{t}}{k_{t}}=\frac{\bar{\kappa}}{\tilde{s}(\bar{\kappa})} E_{t} Q_{t+1} \frac{\left[\left(1-\tau_{t}^{k}\right)\left(R_{t}^{k}-1\right)+(1-\delta)\right]}{Z_{t}}
$$

A agregação dos empreendedores é também trivial, pode ser conferida no apêndice (A).

\footnotetext{
${ }^{8}$ Observe que se $\bar{\kappa}^{*}=0, v\left(\bar{\kappa}^{*}\right)=0$ e $l_{t}=0$. O empreendedor não toma empréstimo no banco porque as condições de mercado não são satisfatórias, isto é, a remuneração líquida da unidade marginal de capital não paga os custos de financiamentos e a incerteza do negócio. Nesse caso, a demanda por capital é igual aos recursos próprios do empreendedor $Q_{t} k_{t+1}=n_{t}$.
} 


\subsubsection{Bancos}

Os bancos são firmas que intermedeiam recursos entre agentes poupadores e agentes tomadores de crédito da economia. As famílias são unidades superavitárias que podem alocar sua poupança em diversos ativos, dentre eles os depósitos bancários. Por outro lado, firmas e empreendedores são as unidades que demandam recursos. Existem na economia infinitos bancos idênticos e uniformemente distribuídos no espaço unitário.

A sobressalência dos bancos dentre os intermediários financeiros da economia não é objeto de estudo desta tese. A literatura de banking contém diversas motivações para a existência de bancos, basicamente entendidos como agentes intermediários que gerenciam recursos entre unidades superavitárias e deficitárias do sistema. No modelo a presença dos bancos é defendida pela percepção de ganhos de escala na oferta de crédito, ganhos de escopo na gestão de depósitos e empréstimos e existência de assimetria de informação que implica em custos de verificação para os contratos financeiros. Por tais motivos, a firma bancária surge como um formato eficiente para lidar com essas questões.

Bancos gerenciam ativos diversos, operando em sete mercados no total. Os insumos são os depósitos bancários transacionados em mercado de competição perfeita com as famílias. Os mercados de crédito são quatro: crédito às famílias, crédito às firmas, crédito ao investimento e crédito interbancário. Além desses, há os mercados de títulos públicos e de moeda.

O crédito é um produto diferenciável ${ }^{9}$. Ao contrário do mercado de depósitos bancários, os mercados de créditos operam em competição monopolística pela existência de algum grau de diferenciação na oferta do produto crédito em cada mercado. A diferenciação confere poder de mercado aos bancos ${ }^{10}$ na determinação das taxas de juros em todos os mercados de crédito

\footnotetext{
${ }^{9}$ É possível interpretar a diferenciação do produto de crédito como facilidades operacionais oferecidas pelo banco, associadas ao gerenciamento financeiro dos recursos, por exemplo serviços bancários, ou ainda variedades nos esquemas de pagamentos, como prazos diferenciados, desde que contidos na unidade de tempo considerada. Ou mesmo é possível interpretar a heterogeneidade como diferenciação do produto no espaço geográfico.

${ }^{10}$ Alencar, Nakane \& Kanczuk (2006) utilizam jogos para estudar a estrutura dos mercados de depósitos a prazo, crédito e serviços bancários no Brasil, para dados de municípios nos anos de 2002 e 2003. Os autores concluem
} 
privado. Essa fricção real afeta os juros em equilíbrio e altera a dinâmica de transmissão dos choques econômicos que permeiam pelo mercado bancário, em especial os de política monetária.

As ações do Estado sobre o mercado são controles e restrições impostos não apenas sobre os fluxos financeiros, mas também sobre os estoques dos bancos. A modelagem do setor em média escala segue naturalmente a abordagem de fontes e recursos. Os estoques de cada banco no período $t$ são definidos pela identidade do balanço patrimonial:

$$
\underbrace{l_{t}+\frac{m_{t}}{P_{t}}+b_{t}+a_{t}}_{\text {ativos bancários }}=\underbrace{d_{t}+b c_{t}+i_{t}}_{\text {passivos exigiveis }}+\underbrace{\mathcal{K}_{b, t}}_{\text {capital próprio }}
$$

onde $l_{t}$ é a oferta total de crédito do banco, $m_{t} / P_{t}$ são saldos monetários reais, $b_{t}$ são títulos públicos comprados do governo e $a_{t}$ é o ativo livre de risco. O passivo bancário é composto por depósitos $d_{t}$, empréstimos de última instância $b c_{t}$ tomados com o banqueiro central, crédito interbancário $i_{t}$ e capital bancário $\mathcal{K}_{t}$.

\section{Ativos Bancários}

Independente de como foram captados, os recursos de que o banco dispõe serão alocados em ativos como crédito, moeda, títulos públicos e ativos livres de risco. Os bancos ofertam produtos de crédito a diferentes agentes: i) firmas que necessitam de antecipar parte da sua folha de salários antes da produção; ii) consumidores que demandam algum volume de crédito para completar sua restrição orçamentária; iii) empreendedores que querem comprar capital fixo dos produtores para realizar projetos de aluguel do capital; e iv) demais bancos. O contrato financeiro com as famílias, firmas e outros bancos é constituído sob informação completa, então o retorno bruto é simplesmente a taxa bruta de juros vezes o volume de crédito. Todavia o contrato financeiro com os empreendedores tem assimetria informacional. Como existem infinitos 
empreendedores demandando crédito, cada banco conseguirá diversificar completamente seu portfolio de empréstimos, de tal forma a eliminar o risco idiossincrático. Portanto o retorno bruto de cada banco é não estocástico e pode ser descrito pela condição de equilíbrio parcial.

O lucro bruto $\Pi_{b, t}^{e}$ do banco $b$ no crédito ao empreendedor $e$ é caracterizado pelo contrato financeiro (ver seção 2.1.4 e apêndice A), conforme equação (2.32). O lucro do banco $b$ no mercado de crédito a empreendedores é $\int_{0}^{1} \Pi_{b, t}^{(e)} d e$, cuja especificação é simplificada pelo condição de equilíbrio parcial. Nos demais mercados, o lucro de cada banco nos mercados de crédito é a simples agregação de tomadores de crédito idênticos. A oferta total de crédito do banco $b$ é a soma das ofertas em todos os mercados de crédito a consumidores, empreendedores, firmas e bancos (indexados por $j, e, i, x$, respectivamente):

$$
l_{t}=\int_{0}^{1} l_{t}^{(j)} d j+\int_{0}^{1} l_{t}^{(e)} d e+\int_{0}^{1} l_{t}^{(i)} d i+\int_{0}^{1} l_{t}^{(x)} d x
$$

Outros ativos disponíveis para o banco são os saldos monetários reais, cujo retorno bruto nominal é igual a 1, os títulos públicos de um período que remuneram à taxa bruta real $R_{t}^{b} \mathrm{e}$ o ativo livre de risco com taxa bruta real de juros $R_{t}$.

\section{Passivos Bancários}

O passivo bancário descreve as fontes dos recursos disponíveis para o banco. Constitui-se basicamente por recursos tomados de terceiros - os depósitos bancários de um período - mais recursos próprios, o capital bancário ou patrimônio líquido. É possível que também apareçam no passivo do banco recursos obtidos no mercado interbancário e empréstimos com a autoridade monetária. $\mathrm{O}$ capital bancário em cada instante $t$ segue a lei de formação:

$$
\mathcal{K}_{b, t+1}=(1-\omega) \mathcal{K}_{b, t}+\Delta_{b, t}+\Theta_{t} \Pi_{b, t+1}
$$

A cada instante do tempo, uma parte do estoque de capital $\omega \in(0,1)$ é liquidada e transferida 
aos demais agentes sob a forma de dividendos. A constituição de novo capital bancário é possível por dois mecanismos internos: i) o banco escolhe $\Delta_{t} \geq 0$ hoje como o volume de recursos destinado à sua capitalização no período seguinte, e tais recursos reduzem o resultado do banco; e ii) quando, sob determinadas condições, o banco perceber lucro $\prod_{t}^{b a n}$ maior que zero, uma fração ${ }^{11} \Theta \in[0,1]$ do rendimento é incorporada ao patrimônio líquido corrente. Quando o banco tem lucro zero, é o primeiro mecanismo que garante a existência de capital bancário no longo prazo ${ }^{12}$. A primazia entre os mecanismos será explorada adiante, no capítulo 3.

Tecnologia Bancária

O balanço patrimonial (2.36) é uma restrição tecnológica per se, todavia capital próprio e depósitos bancários são insumos substitutos perfeitos. Os empréstimos junto à autoridade monetária funcionam como ferramenta extemporânea para lidar com problemas de liquidez e não podem ser considerados insumos produtivos para o banco.

A administração de portfolio é absolutamente relevante na operação dos bancos. A literatura ${ }^{13}$ de banking justifica extensivamente a alocação dos recursos do banco em um portfolio de ativos cujo objetivo é o gerenciamento da liquidez intertemporal, portanto bancos escolhem manter parte dos recursos em ativos de maior liquidez, como a moeda e os títulos do governo, em detrimento da oferta de crédito. Sem essa necessidade de liquidez, aqui traduzida pela tecnologia bancária, os bancos transformariam em oferta de crédito todo o volume de recursos captados, uma vez que o retorno do crédito é superior. Observe portanto que a tecnologia bancária introduz uma noção de risco na visão da instituição financeira que não está apenas relacionada à

\footnotetext{
${ }^{11} \Theta_{t}=\left(1-\iota^{b a n}\right) *\left(1-\tau_{t}^{\Pi^{b a n}}\right)$, onde $\tau_{t}^{\Pi^{b a n}} \in[0,1]$ é a alíquota do imposto sobre os lucros do banco e $\iota^{\text {ban }}$ é a fração do lucro líquido que é distribuída às famílias em cada período.

${ }^{12}$ Iterando a lei de formação, $\mathcal{K}_{n}=(1-\omega)^{n} \mathcal{K}_{0}+\sum_{s=1}^{n}(1-\omega)^{n-s} \Delta_{s-1}+\sum_{s=1}^{n} \Theta_{t}(1-\omega)^{n-s} \prod_{s}^{\text {ban }}$.

${ }^{13}$ A teoria não é homogênea na especificação da função de produção de bancos, nem mesmo na indicação do domínio e contra-domínio. Os textos frequentemente apresentam especificações diversas que combinam apenas os ativos bancários, como em Goodfriend \& McCallum (2007), Edwards \& Vegh (1997) e Canzoneri et al. (2008); outros relacionam ativos com a estrutura do passivos. Todos enfim definem a constituição do portfolio de ativos bancários justificada pela administração de liquidez. Nesse sentido, as especificações guardam equivalência.
} 
adimplência dos contratos de crédito, mas à solvência e às salvaguardas do sistema financeiro.

$\mathrm{Na}$ ausência de fricções regulatórias, os bancos obtêm recursos que combinam capital de terceiros e capital próprio e a composição do passivo determina uma fronteira de produção de crédito. Assume-se que cada firma bancária possui a mesma função de produção:

$$
z_{\mathcal{T} t} \mathcal{T}\left(d_{t}, \mathcal{K}_{t}\right) \geq l_{t}
$$

onde $\mathcal{T}$ é a função de produção com elasticidade de substituição constante entre depósitos bancários e capital próprio. É assumida homogênea de grau um, côncava e estritamente crescente em ambos os argumentos. Depósitos e capital próprio são componentes do passivo bancário e, na visão patrimonial, são fontes de recursos do banco. Por sua vez, crédito é o produto do banco. A tecnologia de produção define a capacidade que a firma bancária possui de ofertar produtos de crédito quando capta recursos de terceiros e possui recursos próprios ${ }^{14}$. Aqui a função de produção descreve a intermediação financeira. Essa abordagem é defendida desde Sealey Calvin W \& Lindley (1977), que argumentam que bancos não são produtores de serviços de depósitos e crédito em essência, mas sim a intermediação é a principal atividade bancária. Nessa linha, depósitos, capital e trabalho devem ser reconhecidos como insumos enquanto crédito e outros ativos diversos são os produtos bancários ${ }^{15}$.

A presença de capital bancário atende a duas necessidades da modelagem. A primeira é representar relações patrimoniais do balanço do banco, em especial as relações utilizadas por reguladores, investidores e supervisores na análise das condições de resiliência financeira. Em termos técnicos, o capital próprio cria uma não linearidade nas fontes de recursos do banco, de

\footnotetext{
${ }^{14}$ Humphrey (1992) utilizou dados de 202 bancos americanos em uma pesquisa empírica para analisar a função bancária. No artigo, mediu produtividade e economias de escala utilizando fluxo e estoques como medidas de produto bancário e empregou tanto técnicas não paramétricas como estimação econométrica convencional. O modelo estrutural da função de produção generalista que contém os conceitos de eficiência e trata os depósitos como produtos intermediários e também insumo bancários. A função custo é do tipo translog e descreve reduções de custos decorrentes de mudança técnica ou de economias de escala. Humphrey (1992) argumenta que as abordagens não paramétricas e econométricas reportam resultados similares na apuração da produtividade total de fatores.

${ }^{15} \mathrm{~A}$ maioria dos estudos de produtividade bancária utilizam a abordagem de intermediação porque existem menos problemas nos dados que a abordagem de produção. De toda forma, não há consenso sobre a função de produção dos bancos.
} 
tal forma que cada tem papel diferenciado na oferta de crédito, o que faz sentido em termos de estrutura financeira.

A tecnologia está sujeita a ciclos de negócios específicos ao banco. A variável $z_{t}$ é um choque agregado estocástico no fator de produtividade total e tem a seguinte lei de movimento:

$$
\ln z_{\mathcal{T} t}=\rho_{z_{\mathcal{T}}} \ln z_{\mathcal{T} t-1}+\epsilon^{z_{\mathcal{T} t}}
$$

onde $\rho_{z_{\mathcal{T}}}$ é a persistência do choque e $\epsilon^{z \mathcal{T} t}$ representa uma inovação i.i.d. com média zero e variância $\sigma_{\epsilon^{z} \mathcal{T}}^{2}$.

A tecnologia de produção não determina de maneira completa a alocação dos ativos bancários para uma conhecida estrutura no passivo, mas define a reserva voluntária de liquidez do banco que deve ser empregada em moeda e títulos públicos:

Definição 2.1 Reserva de Liquidez. É o volume mínimo de recursos voluntários direcionados pelo banco para obter ativos de maior liquidez:

$$
E\left(d_{t}, \mathcal{K}_{t}\right)=d_{t}+\mathcal{K}_{t}-z_{\mathcal{T} t} \mathcal{T}\left(d_{t}, \mathcal{K}_{t}\right)
$$

Sistema de Pagamentos e a Necessidade de Liquidez

A atividade bancária está sujeita a restrições de liquidez intrínsecas ao balanço operacional, pela necessidade de manter uma reserva de recursos que funcione como lastro em caso de liquidação extemporânea dos depósitos de terceiros ${ }^{16}$. Todavia, mesmo em condições de nor-

\footnotetext{
${ }^{16} \mathrm{O}$ banco emprega recursos de terceiros na oferta de crédito ao setor produtivo. Ativos bancários têm menor liquidez que os passivos, pois empréstimos bancários têm maturidade determinada enquanto os depósitos podem ser sacados com antecedência. O descompasso entre esses estoques no tempo define um problema de gestão de liquidez, como em Diamond \& Dybvig (1983) e Diamond \& Rajan (2006), entre outros. Ainda que empréstimos e depósitos sejam modelados em um único período, é válida a abstração sem necessária especificação. Alternati-
} 
malidade, cada banco deve garantir liquidez para saques, pagamentos e transferências em geral entre os agentes bancarizados. O funcionamento do sistema de pagamentos joga um papel relevante na estrutura dos ativos.

Problemas com o gerenciamento da liquidez pelos bancos podem implicar em posições deficitárias de fim de período. Os problemas podem ter origens diversas, desde má administração financeira a choques não antecipados. Porque os pagamentos são compensados dentro da rede bancária, a obrigatória interligação de rede do sistema financeiro transforma um problema atomístico em sistêmico. A saída de firmas bancárias ineficientes em um ajuste clássico de competição de mercado pode significar, no extremo, o comprometimento de todas as firmas do setor. Na conjectura de que crises do sistema financeiro têm elevado custo social, a regulação prudencial para reduzir o risco sistêmico dominou o foco das intervenções durante os últimos anos. O Brasil reagiu com a reforma do seu sistema de pagamentos em 2002, transformando-o do tipo LDL (Liquidação Diferida Líquida) para LBTR (Liquidação Bruta em Tempo Real). Uma vez que impõe a liquidação imediata de pagamentos, o sistema LBTR promove a internalização das externalidades de redes de uma administração de liquidez equivocada. Entretanto a operação do sistema exige que os bancos retenham de forma voluntária ativos de alta liquidez suficientes para garantir a compensação em tempo real pelo valor bruto de pagamentos e transferências. Os encaixes voluntários dos bancos ficam depositados junto ao banqueiro central. Portanto, o sistema LBTR impõe um custo de oportunidade aos bancos sobre os recursos ociosos, que potencialmente seriam destinados ao crédito. A formalização do problema vem a seguir.

Pagamentos e transferências decorrem do comportamento dos depositários e o banco constitui hoje reservas voluntárias em moeda, sob incerteza da quantidade necessária para atender a liquidação de pagamentos amanhã. Se o "colchão" de liquidez revela-se insuficiente para os pagamentos correntes, o banco deve tomar empréstimos de liquidez no mercado interbancário ou junto ao banqueiro central (operações de redesconto), credor de última instância do sistema financeiro. Seja $\mathcal{P}_{t}$ a função pagamento que informa o maior volume líquido de pagamentos 
exigido para o período $t$. $\mathrm{O}$ banco deve atender à restrição de sistema de pagamentos:

$$
\mathcal{P}_{t} \leq \frac{m_{t-1}}{P_{t}}+b c_{t}+i_{t}
$$

$b c_{t+1}$ é o redesconto e $i_{t+1}$ é o crédito interbancário. $\frac{m_{t-1}}{P_{t}}$ é o saldo monetário corrente em termos reais. Assume-se que a função pagamentos esteja regida por uma lei de formação:

$$
\mathcal{P}_{t}=\mathcal{P}\left(d_{t-1}\right)+\varepsilon_{\mathcal{P} t}
$$

sendo $\varepsilon_{\mathcal{P} t}$ um choque i.i.d com média zero e variância $\sigma_{\mathcal{P}}^{2}$.

Uma interpretação alternativa para essa abordagem está relacionada ao sistema fracionário de reservas e sua instabilidade intrínseca. Uma unidade de tempo no modelo reflete o período de empréstimo de recursos ao setor privado, quando o recurso não está disponível. Nesse interim, é permitido, desde que decorrido certo tempo, que depositantes realizem saques dos seus recursos sem perda da remuneração associada. Esses recursos não podem ser realocados ou utilizados na compra de bens até a abertura dos mercados, no período seguinte. A instabilidade do sistema fracionário de reservas é relacionada ao mecanismo de exigência de liquidez, no qual parte dos depósitos pode ser reclamada antes do recebimento dos recursos que estão emprestados. O banco encontra-se em posição de insolvência se não satisfaz a demanda por liquidez dos sacadores. Todavia essa demanda é estocástica, isto é, o valor realizado em cada período depende de fatores parcialmente desconhecidos pelo banco.

A atividade de intermediação financeira é modelada envolvendo uma produção de serviços de depósitos e empréstimos, consoante com a literatura, cite-se, por exemplo, Diaz-Gimenez et al. (1992), Alencar \& Nakane (2004) e Freixas \& Rochet (2008). Seja $\mathcal{C}: \mathbb{R}^{2} \rightarrow \mathbb{R}$ a representação da função custo do banco. Sealey Calvin W \& Lindley (1977) defendem que a abordagem da intermediação financeira deve ultrapassar conceitos puramente físicos e a visão 
do processo econômico ${ }^{17}$ deve emergir. A função custo do banco $\mathcal{C}\left(d_{t-1}, l_{t-1}\right)$ é interpretada como custos operacionais de contratação e gerenciamento dos volumes agregados de depósitos $d_{t}$ e de empréstimos $l_{t}$ e liquidação dos contratos de crédito. Assume-se que a função custo tem retornos decrescentes de escala, mas não é separável ${ }^{18}$, o que garante ganhos de escopo entre depósitos e empréstimos ${ }^{19}$.

O lucro esperado bruto em $t+1$ do banco $b$ no período $t$ é definido por:

$$
\begin{aligned}
E_{t} \Pi_{b, t+1}^{b a n}=\int_{0}^{1} \Pi_{b, t+1}^{(e)} d e+ & \int_{0}^{1} \Pi_{b, t+1}^{(j)} d j+\int_{0}^{1} \Pi_{b, t+1}^{(i)} d i+\int_{0}^{1} \Pi_{b, t+1}^{(x)} d x+R_{t} a_{t}+R_{t}^{b} b_{t} \\
& +E_{t} \frac{m_{t}}{P_{t+1}}-\left[R_{t}^{d} d_{t}+R_{t}^{b c} b c_{t}+R_{t}^{i} i_{t}+\mathcal{K}_{t}+\Delta_{t}+\mathcal{C}\left(d_{t}, l_{t}\right)\right]
\end{aligned}
$$

$\Pi_{b, t+1}^{(.)}$são os lucros em cada mercado de crédito e $a_{t}$ é o ativo livre de risco. Todos os preços e quantidades são conhecidos ainda em $t$, mas apropriados pelo banco em $t+1$, com exceção dos saldos monetários reais cujo valor é esperado.

A dinâmica do problema se estabelece pela necessidade de reter saldos monetários para fins de pagamentos e também porque parte $\Theta$ dos lucros, quando existirem, é incorporada ao capital próprio no período seguinte, com efeitos sobre a tecnologia e o balanço dos bancos. Seja $r_{t, t+j}$ o fator de desconto intertemporal definido pela taxa bruta de juros livre de risco, conforme (2.21). Os lucros futuros esperados do banco em horizonte infinito, quando avaliados aos preços correntes, é chamado em algumas situações de Charter Value:

$$
\mathfrak{V}_{t}=\underbrace{E_{t} \sum_{s=1}^{\infty} r_{t, t+s} \Pi_{t+s}^{b a n}}_{\text {Charter Value }}
$$

\footnotetext{
${ }^{17}$ Citando os autores, Costa (2004) estima uma função custo do tipo translog para bancos brasileiros, tendo depósitos e capital como insumos e obtém boa significância para esses fatores.

${ }^{18}$ A separabilidade entre depósitos e empréstimos determina a independência entre as taxas de juros de depósito e de crédito (FREIXAS; ROCHET, 2008).

${ }^{19}$ Altunbas et al. (2001) estimam uma função custo translog para examinar a estrutura de custos dos bancos em quatro países europeus: França (201 bancos), Alemanha (196), Itália (244) e Espanha (209). Os resultados dão conta de existem economias de escala para bancos maiores. Bancos grandes também apresentaram ganhos de escopo quando aumentam o mix de produtos (ALTUNBAS; MOLYNEUX, 1996; ALTUNBAS et al., 2001)
} 
O problema do banco é maximizar o valor presente de seus lucros líquidos futuros esperados (2.45), descontados no tempo pela taxa de juros risk-free. Maximizar o capital próprio resulta em um problema intertemporal idêntico. $\mathrm{O}$ banco escolhe em $t$ as quantidades de crédito em cada mercado, títulos públicos, títulos livres de risco e moeda como ativos bancários e depósitos, redesconto e empréstimos interbancários no lado do passivo, além do valor de capitalização do seu patrimônio, conforme a lei (2.38). Valores correntes do estoque de capital bancário e das demandas de crédito em cada mercado são conhecidos ex-ante. Assume-se que o banco deve atender totalmente as demandas de crédito em cada mercado para cada nível de taxa de juros. As restrições operacionais que se aplicam são aquelas já detalhadas nesta seção: i) balanço patrimonial (2.36); ii) tecnologia de oferta de crédito relacionada à estruturação do passivo (2.39); e iii) restrição de sistema de pagamentos (2.42). A descrição completa do problema do banco e os detalhes da solução estão no apêndice, seção A, página 204.

\subsubsection{A Oferta de Crédito}

Hipótese 2.1 Assume-se solução interior em todos os mercados de crédito privado.

O banco oferta em todos os mercados de crédito, garantindo contratos sempre que houver demanda. Se a tecnologia do banco for válida, já que torna os fatores não substitutos perfeitos, a hipótese (2.1) garante ainda solução interior para depósitos bancários e capital próprio do banco.

Proposição 2.1 Todos os empréstimos devem ter retornos esperados iguais quando as elasticidadesjuros da demanda forem iguais.

A proposição (2.1) confirma as condições de igualdade entre as oportunidades do banco, tal qual já empregadas na modelagem dos contratos financeiros, quando o retorno do banco para cada nível de solvência foi assumido igual ao retorno esperado que o banco poderia obter se direcionasse o recurso a um outro mercado com as mesmas características. Para cada unidade 
de recurso disponível para crédito a um determinado segmento, o banco deve estar indiferente entre emprestar a esse segmento ou a outro segmento, se ambos têm igual elasticidade-juros da demanda. Todavia as elasticidades-juros da demanda podem não ser iguais.

Proposição 2.2 Sejam dois mercados de crédito com diferentes elasticidades-juros da demanda. Então vale:

$$
\begin{aligned}
R_{b, t}^{l(j)} & =\frac{\theta_{j, t}}{\theta_{x, t}} \frac{\left(\theta_{x, t}-1\right)}{\left(\theta_{j, t}-1\right)} R_{b, t}^{l(x)} \\
\frac{R_{b, t}^{l(e)}}{s(\bar{\kappa})} & =\frac{\theta_{e, t}}{\theta_{x, t}} \frac{\left(\theta_{x, t}-1\right)}{\left(\theta_{e, t}-1\right)} R_{b, t}^{l(x)} \\
R_{b, t}^{l(i)} & =\frac{\theta_{i, t}}{\theta_{x, t}} \frac{\left(\theta_{x, t}-1\right)}{\left(\theta_{i, t}-1\right)} R_{b, t}^{l(x)}
\end{aligned}
$$

Agora é possível generalizar a relação das taxas de juros no crédito aos consumidores, empreendedores, firmas e demais bancos, considerando que o banco atua em competição monopolística, mas está diante de elasticidades diferentes. As diferenças entre as taxas de crédito é explicada como um parâmetro comportamental da demanda por crédito frente à variedade de produtos de crédito que o mercado dispõe para cada setor. A proposição garante ainda que taxas de juros diferentes estão ancoradas no custo marginal do banco, qualquer que seja o destino do crédito. Assumida então a homogeneidade de características operacionais na concessão e liquidação do crédito, é irrelevante para o banco a forma como os recursos disponíveis são alocados em crédito.

As provas das proposições estão no apêndice (A). As condições de ótimo do banco para os mercados de crédito ficam definidas em termos de preços pela proposição (2.2) e em termos de quantidades, uma vez que o banco atende toda a demanda de crédito pelo bem diferenciado para as taxas de juros. A oferta total de crédito do banco é soma das ofertas em cada mercado, segundo 2.37 .

O canal de crédito bank lending de transmissão de política monetária está presente no modelo 
porque i) impõe-se que os bancos são o único meio disponível para firmas, empreendedores e famílias tomarem crédito; e ii) alterações na oferta de depósitos geradas por choques de política monetária alteram imediatamente o volume de recursos disponíveis para o crédito no escopo da tecnologia bancária, porque a substituição com o capital bancário é imperfeita. Os efeitos sobre as taxas são discutidos a seguir, mostrando que outras fricções contribuem para explicar o pass-through de política monetária. O canal de crédito conhecido como broad credit channel foi desenhado conforme Bernanke, Gertler \& Gilchrist (1999) para os empreendedores. A imposição de que os empreendedores jamais acumulam riqueza líquida suficiente para o financiamento próprio dos seus projetos de investimento é equivalente a supor imperfeita substituição entre a riqueza líquida e crédito bancário no financiamento do capital.

A taxa de juros livre de risco $R_{t}$ é a remuneração do título privado livre de risco sob a hipótese de full risk-sharing para as famílias, como em Woodford (2003), mas não é efetiva, uma vez que as famílias são supostas idênticas e superavitárias. Os títulos existentes são moeda, depósitos e títulos públicos. A equação de ótimo para títulos públicos garante que, em equilíbrio, a taxa de juros dos títulos é igual à taxa livre de risco ${ }^{20}$. A condição é central para os resultados do modelo porque definem diretamente o canal de transmissão da política monetária.

\subsubsection{O Custo Marginal do Banco}

Na captação de recursos, o crédito interbancário e empréstimo de última instância serão mais caros do que o custo dos depósitos ${ }^{21}$ e, por tal razão, o banco demanda essas linhas apenas como socorro de liquidez. O nível de capital próprio é predeterminado no início de cada período e a demanda de crédito é conhecida pelo banco. Para uma dada estrutura de passivo bancário constituído por depósitos de terceiros e capital próprio, igual volume de recursos estará a disposição como ativo bancário.

\footnotetext{
${ }^{20}$ Por óbvio, não há modelagem específica para o risco do governo que implique resultado diferente.

${ }^{21}$ As condições que asseguram essa propriedade estão a descritas na seção de demanda por moeda e, com mais detalhes, no A.
} 
Hipótese 2.2 A reserva de liquidez é estritamente maior que zero, para quaisquer níveis de depósitos e capital próprio do banco, isto é, $E\left(d_{t}, \mathcal{K}_{t}\right)>0, \quad \forall d_{t}, \mathcal{K}_{t}$.

A tecnologia do banco, desde que (2.2) seja válida, implica em uma reserva voluntária de liquidez que deve ser alocada em moeda, títulos públicos e ativos livres de risco. A moeda é dominada em retorno pelos títulos que remuneram a juros e a existência da reserva garante solução interior para esses ativos. Em equilíbrio, o ativo livre de risco não é efetivo. Com $R^{b}=R$, o banco aplicará seus recursos excedentes em títulos do governo.

O custo marginal do banco em termos reais $\Sigma_{t}$ é explicado pelo custo de oportunidade de emprestar à taxa livre de risco mais os custos operacionais de produção de crédito mais $\lambda_{2, t}$, que é o preço-sombra da restrição da tecnologia bancária. Esse preço é o custo marginal em termos dos lucros futuros a valor presente de atender a demanda por crédito, pois, uma vez que o capital bancário corrente está predeterminado, o banco deve captar depósitos de acordo com a sua tecnologia. Quando a tecnologia bancária é ativa, bancos têm um custo extra para atender a demanda total de crédito da economia, pois devem captar mais depósitos bancários do que obteriam como resultado do equilíbrio de concorrência perfeita. A inclusão de novos depósitos, por sua vez, está sujeita a outras restrições técnicas que acrescentam custo para ofertar crédito. Entretanto, se a demanda por crédito é suficientemente baixa, para um determinado volume de capital próprio, é possível que o resultado de concorrência livre no mercado de depósitos defina uma quantidade superior àquela que atende a tecnologia, fazendo a restrição inativa com $z_{\mathcal{T} t} \mathcal{T}\left(d_{t}, \mathcal{K}_{t}\right)>l_{t}$. $\Lambda_{t}$ é o valor presente do lucro marginal futuro, representa, portanto, um desconto intertemporal qualificado pela possibilidade de incorporação de lucros ao capital bancário.

$$
\Sigma_{t}=R_{t}+\mathcal{C}_{l_{t}}+\frac{\lambda_{2, t}}{\Lambda_{t}}
$$

Seja $Z_{t}$ a taxa de juros final praticada pelos bancos no mercado de elasticidade $\varepsilon_{Z_{1}}$. Como as taxas ótimas são função apenas do custo marginal e da elasticidade-juros da demanda, o spread 
bancário do lado dos empréstimos é explicado pelo modelo como uma combinação linear entre mark-up, custos operacionais e custos tecnológicos.

$$
Z_{t}\left(1-\frac{1}{\varepsilon_{Z_{1}}}\right)=R_{t}+\mathcal{C}_{l_{t}}+\frac{\lambda_{2, t}}{\Lambda_{t}}
$$

\subsubsection{A Demanda Por Moeda}

A demanda por moeda do banco está relacionada a dois mecanismos do modelo: i) a rentabilidade relativa do ativo monetário frente ao crédito e aos títulos públicos; ii) a necessidade de manter certa liquidez para compensação de pagamentos. Segundo a condição de ótimo, o banco acumula moeda até que o benefício marginal iguale o custo marginal de captação. A oferta total de crédito é determinada pelas quantidades demandadas em cada mercado. A tecnologia do banco impede que todo o passivo captado pelo banco seja alocado em crédito. Portanto, há recursos que devem ser alocados em ativos mais líquidos, como moeda e títulos públicos.

A condição de ótimo da moeda mostra que instrumento de política monetária afeta diretamente o custo de oportunidade da moeda, com efeitos sobre a administração da liquidez dos bancos ${ }^{22}$, como em Canzoneri et al. (2008) e Goodfriend \& McCallum (2007). Em termos operacionais, esse canal de liquidez descreve o mercado aberto de títulos públicos e a implementação operacional moderna da política monetária.

Duas hipóteses (2.3 e 2.4) são feitas para deduzir a demanda por moeda do banco, que consta no apêndice (A). A primeira descarta a manutenção de saldos monetários porque indica que a moeda é dominada em retorno pelo título livre de risco. Somente com deflação a moeda poderia ter rentabilidade superior à uma unidade e apenas após um nível adequado de deflação a moeda poderia ser tão rentável quanto qualquer outro ativo da economia, resultado que é

\footnotetext{
${ }^{22}$ Christiano \& Eichenbaum (1995) estudam o efeito liquidez como canal de transmissão de política monetária utilizando um modelo de real business cycles com restrição cash-in-advance e certa rigidez no plano de poupança das famílias. Os autores notam a validade do canal para produzir resultados de política monetária afetando produto, emprego e inflação no curto prazo, consistentes com a evidência empírica.
} 
bastante conhecido como Regra de Friedman. Todavia em outras situações de otimalidade com ausência de deflação em equilíbrio, a moeda é estritamente dominada em retorno pelos demais ativos financeiros. Isso significa no contexto do banco que, na ausência de fricções operacionais, como a necessidade de manter liquidez para pagamentos, a demanda do banco por saldos monetários é zero. Os depósitos bancários e o capital próprio têm solução interior, assim como o mercado de crédito, mas a diferença entre passivos totais e o crédito deve ser alocado em ativos mais rentáveis, sempre que 2.3 vale.

Hipótese 2.3 $R_{t}>1$.

Hipótese 2.4 $E_{t} \mathcal{P}_{t+1}>0$.

A segunda hipótese assume a existência de alguma necessidade de liquidez para pagamentos, o que efetivamente determinará que a restrição de liquidez será efetiva. Para atender a necessidade de pagamentos o banco poderia adquirir instrumentos custosos, como moeda ou remédios de liquidez. Em tese, haveria alguma situação em que é possível que o banco não mantenha moeda para atender a restrição de liquidez, valendo-se dos instrumentos de redesconto e do interbancário. O apêndice (A) mostra que tal situação pode ser descartada para taxas de depósitos compulsórios suficientemente altas, obviamente acima da taxa de juros livre de risco, de certa forma que atendam a hipótese 2.5. O mercado interbancário, em equilíbrio, não realiza trocas.

Hipótese $2.5\left(E_{t} R_{t+1}^{b c}-E_{t} R_{t+1}\right)>\left(E_{t} \pi_{t+1} R_{t+1}-1\right) \frac{\Lambda_{t}}{\Lambda_{t+1}} \quad \forall t$.

A demanda por moeda do banco (2.51) será o valor esperado do volume de pagamentos no período seguinte, considerando-se ainda a perda de valor da moeda entre os períodos.

$$
\frac{m_{t}}{P_{t}}=E_{t} \pi_{t+1} \mathcal{P}_{t+1}
$$




\subsubsection{O Passivo Bancário}

Dado que a restrição de liquidez é efetiva porque sempre é exigido um volume não nulo de ativos líquidos para pagamentos e a constituição desses ativos é realizada ex-ante em moeda, uma vez que o custo dos instrumentos de liquidez são suficientemente elevados, o banco pode buscar remédios de liquidez quando da realização dos serviços de pagamentos do período seguinte. Em verdade, a demanda por instrumentos de liquidez é justificada apenas por surpresa no volume de pagamentos. Os dois instrumentos de liquidez disponíveis para fechar a conta no período corrente são os empréstimos tomados no mercado interbancário ou empréstimos obtidos junto ao banqueiro central - operação de redesconto.

A hipótese (2.6) sobre os juros interbancários é mandatória para garantir consistência de modelagem. Os juros no mercado interbancário são os mesmos, independente do que motivou o crédito.

Hipótese 2.6 $R_{b, t}^{i}=R_{b, t}^{l(x)}\left(>R_{t}\right)$

A taxa de juros do mercado interbancário é superior à taxa de juros livre de risco pela equação (2.50). A simetria entre os bancos resulta em um mercado interbancário sem trocas, todavia, $\left.i_{t}=0 \quad \forall t\right)$. O redesconto é o único recurso efetivamente disponível em caso de necessidade de liquidez do sistema ${ }^{23}$. A demanda por recursos de redesconto será conforme equação (2.52) e os detalhes estão no apêndice.

$$
b c_{t}=\max \left(0, \mathcal{P}_{t}-\frac{m_{t-1}}{P_{t-1}} \frac{1}{\pi_{t}}\right)
$$

A hipótese 2.1, associada à característica da tecnologia bancária de complementaridade entre

\footnotetext{
${ }^{23}$ Extensivamente, se não vale a primeira desigualdade em (2.5) o custo de captação junto ao banco central é inferior ao custo de funding no mercado interbancário e o mercado interbancário estaria fechado da mesma forma, porque seria dominado em termos dos custos para o banco.
} 
os fatores depósitos bancários e capital próprio, gera por consequência que depósitos bancários tem solução interior. A demanda do banco pelo fator produtivo depósitos é descrita pela equação (2.53). A condição marginal ótima determina que o banco demande até o ponto em que o benefício marginal da captação de recursos de terceiros seja igual ao custo marginal de reter depósitos bancários. O custo de manter depósitos pode ser decomposto em pagamento de juros ao depositante, custos operacionais e custo de oportunidade da moeda pela retenção maior de saldos monetários, uma vez que há expectativa de maior necessidade de liquidez para pagamentos. No apêndice (A) estão os detalhes.

$$
R^{d}+\mathcal{C}_{d}+\left(R-E \frac{1}{\pi^{\prime}}\right) \mathcal{P}^{\prime}{ }_{d}=R+\frac{1}{\Lambda} \lambda_{2} z_{\mathcal{T}} \mathcal{T}_{d}
$$

Proposição 2.3 $\left(R_{t}^{l}>R_{t}^{b}=\right) R_{t}>R_{t}^{d}, \quad \forall t$

O depósito bancário adicional expande o ativo bancário em uma unidade, que se subdivide em dois estoques: uma fração amplia a oferta de crédito e a outra fração aumenta a reserva de liquidez. O benefício marginal é a remuneração pela taxa de juros do título público do ativo bancário adicional mais o spread dos juros privados sobre os juros do título público que corre sobre o crédito marginal. Obviamente, se a demanda agregada já for atendida no nível de juros sobre depósitos, o banco constitui todo o ativo marginal em títulos públicos. $\lambda_{2} / \Lambda=\Sigma-C_{L}-R$ (equação 2.49) informa precisamente o preço em termos de spread de juros que o banco percebe se houver demanda marginal de crédito, no escopo da tecnologia bancária. A proposição (2.3) decorre diretamente da condição de ótimo e das proposições anteriores.

Por fim, a escolha ótima do nível de capitalização descreve o trade-off que é posto para o banco entre lucro e capital próprio. O banco escolhe o nível de capitalização de tal forma que ajusta o custo em termos de lucros dispensados aos ganhos na formação do estoque de capital próprio. De fato, essa ferramenta permite ao banco "trocar" lucros por capital, uma vez que os lucros são determinados em equilíbrio de competição monopolística e não diretamente controlados por cada banco. 
Apesar da competição monopolística, não há qualquer rigidez de preços sobre as taxas de juros, na forma como impuseram Gerali et al. (2010). Em equilíbrio, a existência de lucros será contestada por firmas bancárias incumbentes com novas variedades de produtos, quando não há barreiras à entrada. O lucro dos bancos e da indústria será zero, portanto, em equilíbrio. $\mathrm{Na}$ ausência de lucros econômicos, é a capitalização que garante a existência de capital bancário em equilíbrio, uma vez que a solução interior para o capital bancário é uma necessidade da tecnologia de intermediação financeira.

No apêndice (A) estão detalhadas as relações agregadas que finalizam o tratamento do mercado bancário.

\subsubsection{Governo}

Para a modelagem do governo, segue-se Schmitt-Grohé \& Uribe (2005). O governo consome em cada período $G_{t}$ unidades do bem composto. A demanda do governo pelos bens intermediários é dada por:

$$
G_{i t}=G_{t}\left(\frac{P_{i t}}{P_{t}}\right)^{-\eta}
$$

Assume-se que os gastos do governo com bens finais são exógenos, mas que a taxa de crescimento segue um processo auto-regressivo de primeira ordem, conforme especifica:

$$
\ln \left(\frac{G_{t}}{\bar{G}}\right)=\rho_{G} \ln \left(\frac{G_{t-1}}{\bar{G}}\right)+\epsilon_{t}^{G}
$$

São parâmetros $\rho_{G} \in(-1,1)$ e $\bar{G}>0$ e $\epsilon_{t}^{G}$ é um choque i.i.d. com média zero e variância $\sigma_{\epsilon^{G}}^{2}$. O parâmetro $\bar{G}$ é o nível de consumo do governo em estado estacionário.

Outra origem de dispêndio são as transferências $T_{t}$ para as famílias, medidas em unidades do bem composto. Similarmente aos gastos com consumo, assume-se que as transferências são 
exógenas e o desvio do estado estacionário segue o seguinte processo auto-regressivo:

$$
\ln \left(\frac{T_{t}}{\bar{T}}\right)=\rho_{T} \ln \left(\frac{T_{t-1}}{\bar{T}}\right)+\epsilon_{t}^{T}
$$

$\rho_{T} \in(-1,1)$ e $\bar{T}>0$ são parâmetros e $\epsilon_{t}^{T}$ é um choque i.i.d. com média zero e variância $\sigma_{\epsilon^{T}}^{2}$. O parâmetro $\bar{T}$ mede o nível de transferências realizado pelo governo para as famílias, em estado estacionário.

A estrutura tributária é composta por quatro impostos ad valorem sobre as rendas do trabalho, capital e lucros das firmas e bancos. A arrecadação total do governo é dada pela equação (2.57). Em cada período $t$, as despesas do governo são a compra de bens finais $P_{t} G_{t}$, o "resgate" da emissão monetária $M_{t-1}^{s}$ do período anterior e a quitação dos títulos públicos emitidos no passado $R_{t-1}^{b} B_{t-1}^{s}$. O governo dispõe da arrecadação fiscal $\mathbb{T}_{t}$ e da emissão de moeda $M_{t}^{s}$ para cumprir com tais despesas. A autoridade monetária, vinculada ao governo, atende toda a demanda de crédito de redesconto dos bancos que remuneram à taxa administrada $R_{t}^{b c}$. A autoridade fiscal fecha o déficit orçamentário pela emissão de títulos de dívida pública mobiliária $B_{t}^{s}$ de um período que remuneram à taxa de juros $R_{t}^{b}$ e que são adquiridos pelos bancos e pelas famílias. A restrição orçamentária do governo é dada pela equação (2.58):

$$
\begin{aligned}
\mathbb{T}_{t} & =\tau_{t}^{k} R_{t}^{k} K_{t}+\tau_{t}^{h} W_{t} H_{t}+\tau_{t}^{\Pi^{f}} \Pi_{t}^{\text {firmas }}+\tau_{t}^{\Pi^{b}} \Pi_{t}^{\text {bancos }} \\
B_{t}+\frac{M_{t}}{P_{t}} & =G_{t}+T_{t}+B C_{t}+R_{t-1}^{b} B_{t-1}+\frac{M_{t-1}}{P_{t-1}} \frac{1}{\pi_{t}}-\left(\mathbb{T}_{t}+R_{t-1}^{b c} B C_{t-1}^{s}\right)
\end{aligned}
$$

É lugar comum na literatura representar a política monetária como uma regra de Taylor tão parcimoniosa quanto possível. Assume-se no modelo que a autoridade monetária atua segundo a regra de juros (2.59):

$$
\ln \left(\frac{R_{t}^{b}}{\bar{R}^{b}}\right)=\rho \ln \left(\frac{R_{t-1}^{b}}{\bar{R}^{b}}\right)+(1-\rho)\left[\mu_{\pi} \ln \left(\frac{\pi_{t}}{\bar{\pi}}\right)+\mu_{y} \ln \left(\frac{Y_{t}}{\bar{Y}}\right)\right]+\epsilon_{t},
$$

sendo $\epsilon_{t}$ é um choque estocástico de política monetária de média zero e variância $\sigma_{\epsilon}^{2}$. 
A política fiscal no modelo é Ricardiana no sentido de Woodford (2003) e passiva no sentido de Leeper (1991). O superávit primário se ajusta para estabilizar a dívida e garantir que a restrição orçamentária do governo é satisfeita em qualquer ponto do tempo. Dessa forma, os detalhes de implementação da política tributária não têm quaisquer impactos sobre a inflação ou outras variáveis agregadas. Como consequência não se faz necessário especificar detalhes para a política fiscal. Assume-se, todavia, que as alíquotas são constantes no tempo.

\subsection{Conceitos e Medidas}

Os três objetivos que norteiam as intervenções do Estado sobre o mercado bancário, também chamados aqui de "conceitos", devem ser mensurados em alguma dimensão do modelo apresentado. As métricas propostas abaixo são auxiliares importantes na análise das propriedades estáticas e dinâmicas que será empreendida mais adiante. O conjunto de medidas é propositivo e não exaustivo.

\section{Eficiência Microeconômica}

1. Spread total. A ausência de fricções no mercado financeiro geraria como resultado famílias e firmas trocando à taxa livre de risco. A simples existência de custos de administração dos depósitos e do crédito já implica em alguma distância entre as taxas de juros de poupadores e tomadores, enquanto as demais fricções modeladas ampliam essa margem. O modelo permite obter diretamente o spread do setor bancário, porque o custo marginal do banco é conhecido. Define-se spread total como a razão entre o custo marginal bruto do crédito e a taxa bruta de juros que remunera os depósitos bancários $\frac{\Sigma_{t}}{R_{t}^{d}}$.

2. Spread na captação. É a razão entre as taxas brutas de juros livre de risco e dos depósitos bancários, $\frac{R_{t}}{R_{t}^{d}}$. No conceito de eficiência sem fricções, não haveria diferença entre as taxas, as famílias receberiam a taxa bruta livre de risco pela disposição dos recursos. As famílias aceitam a taxa inferior porque percebem serviços transacionais associados aos depósitos bancários. O banco oferta abaixo da taxa livre de risco porque existem 
custos administrativos de manter depósitos e custos de oportunidade pela disposição de liquidez para pagamentos, conforme equação (2.53) de oferta de depósitos.

3. Spread na oferta. É a diferença entre o custo marginal bruto do crédito e a taxa bruta de juros livre de risco, $\frac{\Sigma_{t}}{R_{t}}$. Sem fricções nos mercados financeiros, as firmas e empreendedores deveriam pagar a taxa livre de risco pela tomada de crédito. Por óbvio, o spread total é a soma dos spreads na captação e na oferta. A separação visa estudar a formação do spread bancário e suas distorções.

4. Mark-up médio do mercado bancário. As taxas brutas de crédito todavia recebem uma margem adicional sobre o custo marginal bruto, relacionada apenas com o poder de mercado que possuem os bancos na oferta de produtos diferenciados. A margem em cada mercado está associada, em equilíbrio, somente à elasticidade-juros da demanda. O mark-up médio é a média dos mark-ups nos mercados em que os bancos ofertam, ponderados pelo volume de crédito:

$$
\frac{R_{t}^{(j) l} L_{t}^{(j)}+R_{t}^{(e) l} L_{t}^{(e)}+R_{t}^{(i) l} L_{t}^{(i)}+R_{t}^{(x) l} L_{t}^{(x)}}{\Sigma_{t} L_{t}}
$$

Mark-ups maiores estão explicados apenas pelo maior poder de mercado, uma vez que os custos marginais são iguais. Portanto, há ineficiência alocativa sob o preceito de competição perfeita.

5. Alavancagem. É a razão entre crédito e depósitos bancários, $\frac{L_{t}}{D_{t}}$. Como é uma relação produto/insumo no setor e a tecnologia bancária é do tipo Cobb-Douglas, maiores alavancagens significam maior produtividade do insumo depósito bancário.

\section{Resiliência Financeira}

1. Nível crítico de solvência, $\kappa_{t}$ é obtido diretamente do modelo e representa a capacidade de pagamento dos empreendedores. Por outro lado, determina para o banco o nível de perda por inadimplência do mercado. Nesse sentido é um indicador de qualidade dos ativos do banco. O nível crítico é também a parcela da renda futura do empreendedor empenhada para quitar o contrato financeiro e mesmo os empreendedores adimplentes 
terão retornos menores com níveis maiores, o que reduz o colateral da economia. Sob essa ótica, é também uma medida de exposição financeira do setor real.

2. Exposição (1). $\frac{D_{t}}{\left(D_{t}+\mathcal{K}_{t}\right)}$ é a fração de recursos de terceiros sobre os ativos/passivos totais do banco representativo. No sentido de que representa o passivo bancário exigível em termos de liquidez é uma métrica de exposição. A ideia implícita é que, na ocorrência de instabilidades no setor bancário, os depositantes executam os seus recursos. A medida define a dívida exigível do banco em relação ao seus recursos totais.

3. Exposição (2). $\frac{D_{t}}{\mathcal{K}_{t}}$ é uma outra medida de resiliência financeira do mercado. Posto que os depósitos bancários são recursos de terceiros e possuem maior instabilidade do que o capital bancário, que é um estoque, a razão explica a exposição do banco na suposição de crises bancárias, representando a capacidade de o banco oferecer garantias aos depositantes. Esse índice é sutilmente diferente do anterior porque desconsidera o tamanho do banco.

4. Lastro. $\frac{\mathcal{K}_{t}}{L_{t}}$ pode ser também uma medida de produtividade do capital bancário, mas reflete principalmente a capacidade de o banco absorver falhas na precificação dos seus ativos, oferecendo garantias aos depositantes, agora no caso de estresses no lado dos ativos de crédito. É por isso utilizado como índice de regulação prudencial nos termos de Basileia I e II.

5. Liquidez. $\left(1-\frac{L_{t}}{\left(D_{t}+\mathcal{K}_{t}\right)}\right)$ mede quanto dos recursos totais são mantidos em ativos de liquidez maior, como moeda e títulos públicos. Este índice representa também garantias aos depositantes em caso de execução bancária das dívidas bancárias.

Causas de instabilidades no setor bancário foram analisadas por Benston \& Kaufman (1995), que compilam quatro motivações para explicar os estresses bancários no sistema financeiro americano: i) expansão excepcional do crédito bancário antes das crises; ii) choques externos e independentes das condições do banco que levam os depositantes a saques extemporâneos, reduzindo as reservas bancárias; iii) assimetria de informação em níveis elevados tais que os 
depositantes não avaliam corretamente os ativos dos bancos; e iv) regulações e restrições legais que afetam principalmente a estrutura patrimonial dos bancos, causando exposição desnecessária à falhas para as firmas mais prejudicadas.

A literatura empírica que trata de crises bancárias é recorrente no uso de medidas de exposição e inadimplência idênticas ou similares como indicadores da solidez financeira do setor na economia. A citar, Allen \& Gale (2000), Barth, Caprio \& Levine (2000), Barth, Caprio \& Levine (2001), Barth, Caprio \& Levine (2002), Barth, Caprio \& Levine (2005), ou ainda Carneiro et al. (1994) e Puga (1999).

\section{Estabilidade Macroeconômica}

1. Agregados econômicos em estado estacionário. O nível de atividade econômica em estado estacionário constitui per se uma métrica para analisar a estabilidade macroeconômica. Outros agregados como o consumo e o investimento são medidas interessantes para a análise de composição do resultado macro.

2. Bem-estar. Análises dinâmicas de bem-estar de políticas solicitam métodos de solução de segunda ordem, embora as as medidas de bem-estar tomadas em estado estacionário não estão sujeitas às complicações decorrentes de dinâmicas de ajustamento. A possibilidade de explicitar o estado estacionário em nível permite medir o nível de bem-estar para utilizá-lo em estáticas comparativas de longo prazo, afora as questões relacionadas à dinâmica de ajustamento.

3. Outros aspectos importantes para a Macroeconomia estão relacionados à dinâmica do modelo e podem ser auferidos pela análise gráfica das respostas a impulsos. Assim, as medidas importantes para construir o conceito de estabilidade macroeconômica estão relacionadas à efetividade da regra de juros, à noção de convergência (meia-vida) ao estado estacionário e à efetividade do canal de crédito na economia. 


\subsection{Equilíbrio Geral Competitivo}

\subsubsection{Formas Funcionais}

A utilidade instantânea das famílias no período $t$ é uma função assumida aditiva e separável entre bens, lazer, saldos monetários reais e depósitos bancários, na forma como é tradicionalmente usada na literatura ${ }^{24}$ :

$U\left(C_{t}, H_{t}, M_{t} / P_{t}, D_{t}, B_{t}\right)=\ln \left(C_{t}-b C_{t-1}\right)+\varsigma_{1} \ln \left(1-H_{t}\right)+\varsigma_{2} \ln \left(\frac{M_{t}}{P_{t}}\right)+\varsigma_{3} \ln \left(D_{t}\right)++\varsigma_{4} \ln \left(B_{t}\right)$

com $\varsigma_{(.)} \in[0,+\infty)$ sendo os coeficientes de utilidade relativos à utilidade log-unitária do consumo de bem final ${ }^{25}$. A produção de bens finais também é usual na literatura, assumida do tipo Cobb-Douglas com retornos constantes de escala, sendo $A \in \mathbb{R}_{+}$o nível tecnológico e $\alpha \in[0,1]$ a elasticidade-produto do capital:

$$
F\left(K_{t}, H_{t}\right)=A K_{t}^{\alpha} H_{t}^{1-\alpha}
$$

Seguindo Christiano, Eichenbaum \& Evans (2005) e Schmitt-Grohé \& Uribe (2005), a função custo de ajustamento do investimento tem forma quadrática, com $\varpi \geq 0$ denotando a velocidade de ajuste:

$$
\mathcal{S}\left(\frac{I_{t}}{I_{t-1}}\right)=\frac{\varpi}{2}\left(\frac{I_{t}}{I_{t-1}}-1\right)^{2}
$$

A formulação garante as propriedades $\mathcal{S}(1)=0$ e $\mathcal{S}^{\prime}(1)=0$ e $\mathcal{S}^{\prime \prime}(1)=\varpi>0$, que determinam a ausência de custos de ajustamento de primeira ordem na vizinhança do estado estacionário

\footnotetext{
${ }^{24}$ Utilizando GMM para estimar as condições de primeira ordem da família, Alencar (2002) e Alencar \& Nakane (2003) mostram que a especificação logarítmica, aditiva e separável não é rejeitada nos dados da economia brasileira e advoga que há evidências relevantes para a presença da moeda na função utilidade. Esses resultados validam para o Brasil essa especificação usual da literatura macro internacional e asseguram que a moeda traz ganhos transacionais reais que podem ser descritos na função utilidade, ao mesmo tempo que trazem alguma segurança para a extrapolação dos ganhos transacionais para outras formas de ativos, como aqui foi empregada.

${ }^{25}$ Recordando, os títulos públicos aparecem na função utilidade apenas por formalidade de modelagem. $\varsigma_{4}$ é assumido zero na calibração.
} 
determinístico.

Para a distribuição acumulada de probabilidade $\Phi$ do choque idiossincrático do empreendedor, cujo suporte é não negativo, assume-se descrita por uma função lognormal ${ }^{26} \mathrm{com}_{\text {média }} \mu_{\Phi} \mathrm{e}$ variância $\sigma_{\Phi}^{2}$.

A tecnologia de produção de produtos de crédito dos bancos é assumida do tipo Cobb-Douglas, que garante a estacionaridade da relação entre depósitos bancários e capital próprio:

$$
\mathcal{T}\left(D_{t}, \mathcal{K}_{t}\right)=\left(D_{t}\right)^{\alpha_{b}}\left(\mathcal{K}_{t}\right)^{\beta_{b}}
$$

$\alpha_{b}, \beta_{b} \in(0,1]$ são as elasticidades-crédito dos depósitos bancários e do capital próprio, respectivamente. Já a função custo do banco é log-linear, com coeficientes $\nu_{(.)} \geq 0$. O coeficiente ${ }^{27}$ $\nu_{3}$, se não nulo, determina ganhos de escopo para o banco na operação conjunta de depósitos bancários e crédito:

$$
\mathcal{C}\left(D_{t}, L_{t}\right)=\overline{\mathcal{C}}+\nu_{1} \ln \left(D_{t}+1\right)+\nu_{2} \ln \left(L_{t}+1\right)-\nu_{3} \ln \left(D_{t} L_{t}+1\right)
$$

em que $\overline{\mathcal{C}}$ é um custo fixo operacional relacionado à estrutura permanente de operação dos bancos.

Por fim, a função que informa a maior necessidade de liquidez no período, em um sistema de pagamentos de liquidação bruta em tempo real, é assumida log-linear, com $\eta_{1} \geq 0$ :

$$
\mathcal{P}\left(D_{t-1} ; \varepsilon_{\mathcal{P} t}\right)=\eta_{1} \ln \left(D_{t-1}+1\right)
$$

${ }^{26}$ De forma equivalente, escreve-se $\Phi\left(\bar{\kappa} ; \mu_{\Phi}, \sigma_{\Phi}\right)=\mathcal{N}\left(\frac{\ln \bar{\kappa}-\mu_{\Phi}}{\sigma_{\Phi}}\right)$, onde $\mathcal{N}$ é a distribuição normal padrão acumulada. Então $\phi$ é a função densidade de probabilidade correspondente a $\Phi$, tal que $\phi\left(\bar{\kappa} ; \mu_{\Phi}, \sigma_{\Phi}\right)=$ $\Phi^{\prime}\left(\bar{\kappa} ; \mu_{\Phi}, \sigma_{\Phi}\right)$. Por sua vez, a função definida por $\mathcal{H}(x)=\int_{0}^{x} \kappa \psi(\kappa) d \kappa=E[\kappa \mid \kappa>x] P[\kappa>x]$ fica: $\mathcal{H}(x)=1-e^{\mu_{\Phi}+\frac{1}{2} \sigma_{\Phi}^{2}} \mathcal{N}\left(\frac{\mu_{\Phi}+\sigma_{\Phi}^{2}-\ln x}{\sigma_{\Phi}}\right)$. A descrição das funções em função da distribuição normal é conveniente por razões computacionais.

${ }^{27}$ A derivada cruzada $\mathcal{C}_{L D}=-\nu_{3} \frac{1}{\left(D_{t+1} L_{t}+1\right)^{2}}<0$. 


\subsubsection{Definição do Equilíbrio}

Suponha que exista um sistema de preços que garante o equilíbrio na economia descrita pelo modelo apresentado. O equilíbrio competitivo dessa economia é definido abaixo.

\section{Definição 2.2 Equilíbrio Geral Competitivo}

(i) sequências de alocações

$$
\begin{aligned}
& \left\{C_{t}, H_{t}, K_{t}, I_{t}, M_{t}^{f a m}, B_{t}^{f a m}, M_{t}^{b a n}, B_{t}^{b a n}, D_{t}, F_{t}, V_{t}^{f i r}, V_{t}^{e m p}, V_{t}^{b a n}, \bar{L}, Y_{t}, K_{t}, I_{t},\right. \\
& \quad \mathcal{K}_{b_{t}}, \Delta_{b, t}, k_{e, t}, n_{e, t}, l_{b, t}^{d(j)}, l_{b, t}^{d(e)}, l_{b, t}^{d(i)}, l_{b, t}^{d(x)} l_{b, t}^{(j)}, l_{b, t}^{(e)}, l_{b, t}^{(i)}, l_{b, t}^{(x)}, m_{b, t}, b_{b, t}, d_{b, t}, b c_{b, t}, i_{b, t}, \\
& \left.\quad \Pi_{t}^{f i r}, \Pi_{t}^{b a n}, M_{t}, B_{t}, B C_{t}\right\}_{t=0}^{\infty} ;
\end{aligned}
$$

(ii) sequências de preços

$\left\{P_{t}, W_{t}, \pi_{t}, Q_{t}, R_{t}, R_{t}^{b}, R_{t}^{k}, R_{t}^{d}, R_{t}^{b c}, R_{t}^{d}, R_{t}^{i}, R_{t}^{l(j)}, R_{t}^{l(e)}, R_{t}^{l(i)}, R_{t}^{l(x)}, R_{b, t}^{l(j)}, R_{b, t}^{l(e)}, R_{b, t}^{l(i)}, R_{b, t}^{l(x)}\right.$, $\left.Z_{t}^{f a m}, Z_{t}^{f i r}, Z_{t}^{e m p}, \tau_{t}^{k}, \tau_{t}^{h}, \tau_{t}^{\Pi^{f i r}}, \tau_{t}^{\Pi^{\text {ban }}}\right\}_{t=0}^{\infty}$

(iii) sequências de multiplicadores de Lagrange

$$
\left\{\Omega_{t}, \lambda_{2 t}, \Sigma_{t}, \Lambda_{t}\right\}_{t=0}^{\infty}
$$

(iv) processos estocásticos

$$
\left\{z_{t}, G_{t}, T_{t}, R_{t}, \mathcal{P}_{t}, z_{\mathcal{T} t}\right\}
$$

(v) parâmetros

$$
\begin{gathered}
\left\{\varsigma_{1}, \varsigma_{2}, \varsigma_{3}, \varsigma_{4}, \beta, b, A, \alpha, \alpha_{f}, \chi_{f}, \eta, \nu, \iota, \varpi, \delta, \sigma_{\Phi}, \gamma, \mu, A^{b a n}, \alpha_{b}, \beta_{b}, \nu_{1}, \nu_{2}, \nu_{3}, \theta_{x}, \eta_{1}, \omega, \iota^{\text {ban }},\right. \\
\left.\mu_{\pi}, \mu_{Y}, \rho_{z}, \rho_{z_{\mathcal{T}}}, \rho_{\mathcal{P}}, \rho, \rho_{G}, \rho_{T}, \rho_{\theta}, \sigma_{z}, \sigma_{z_{\mathcal{T}}}, \sigma_{\mathcal{P}}, \sigma, \sigma_{G}, \sigma_{T}, \sigma_{\theta}\right\} ;
\end{gathered}
$$

tais que:

1. Dadas as sequências de preços $\left\{P_{t}, W_{t}, R_{t}^{d}, R_{t}^{b}, Z_{t}^{\text {fam }}, \tau_{t}^{h}\right\}_{t=0}^{\infty}$, alocações $\left\{M_{t-1}^{\text {fam }}, V_{t}^{\text {fir }}\right.$, $\left.V_{t}^{\text {emp }}, V_{t}^{\text {ban }}, \bar{L}\right\}_{t=0}^{\infty}$ processos estocásticos $\left\{R_{t}, T_{t}\right\}_{t=0}^{\infty}$ e parâmetros, as sequências de alocações $\left\{C_{t}, H_{t}, M_{t}^{\text {fam }}, D_{t}, B_{t}^{\text {fam }}\right\}_{t=0}^{\infty}$ resolvem o problema da família (A.1, p. 191); 
2. Dadas as sequências de preços $\left\{P_{t}, W_{t}, R_{t}^{k}, Z_{t}^{f i r}, \pi_{t}\right\}_{t=0}^{\infty}$, alocações $\left\{Y_{t}, \psi\right\}_{t=0}^{\infty}$, multiplicador de Lagrange $\left\{\Omega_{t}\right\}_{t=0}^{\infty}$, processos estocásticos $\left\{R_{t}, z_{t}\right\}_{t=0}^{\infty}$ e parâmetros, as sequências de alocações $\left\{\tilde{p}_{i, t}, k_{i, t}^{d}, h_{i, t}^{d}, l_{i, t}^{d}\right\}_{t=0}^{\infty}$ resolvem o problema da firma $(A .3, p$. 197);

3. Dadas as sequências de preços $\left\{P_{t}, Q_{t}\right\}_{t=0}^{\infty}$, alocação $\left\{K_{t-1}\right\}_{t=0}^{\infty}$, o processo estocástico $\left\{R_{t}\right\}_{t=0}^{\infty}$ e parâmetros, as sequências de alocações $\left\{I_{t}\right\}_{t=0}^{\infty}$ resolvem o problema dos produtores de capital (A.4, p. 200);

4. Dadas as sequências de preços $\left\{Q_{t}, R_{t}^{k}, Z_{t}^{e m p}, \tau_{t}^{k}\right\}_{t=0}^{\infty}$, alocações $\left\{k_{e, t}, n_{e, t}, F_{t}\right\}_{t=0}^{\infty}$,o processo estocástico $\left\{R_{t}\right\}_{t=0}^{\infty}$ e parâmetros, as sequências de alocações $\left\{l_{e, t}, \bar{\kappa}, R_{e, t}^{l}\right\}_{t=0}^{\infty}$ são compatíveis com a definição do contrato financeiro (A.5, p. 201);

5. Dadas as sequências de preços $\left\{P_{t}, \pi_{t}, R_{t}^{b}, R_{t}^{b c}, R_{t}^{d}, R_{t}^{i}, R_{t}^{l(j)}, R_{t}^{l(e)}, R_{t}^{l(i)}, R_{t}^{l(x)}\right\}_{t=0}^{\infty}$, alocações $\left\{\mathcal{K}_{b, t}, m_{b, t-1}, d_{b, t-1}, l_{b, t}^{d(j)}, l_{b, t}^{d(e)}, l_{b, t}^{d(i)}, l_{b, t}^{d(x)}\right\}_{t=0}^{\infty}$, multiplicadores de Lagrange $\left\{\lambda_{2_{t}}\right.$, $\left.\Sigma_{t}, \Lambda_{t}\right\}_{t=0}^{\infty}$, processos estocásticos $\left\{R_{t}, \mathcal{P}_{t}, z_{\mathcal{T} t}\right\}_{t=0}^{\infty}$ e parâmetros, as sequências de alocações $\left\{R_{b, t}^{l(j)}, R_{b, t}^{l(e)}, R_{b, t}^{l(i)}, R_{b, t}^{l(x)}, l_{b, t}^{(j)}, l_{b, t}^{(e)}, l_{b, t}^{(i)}, l_{b, t}^{(x)}, m_{b, t}, b_{b, t}, d_{b, t}, b c_{b, t}, i_{b, t}, \Delta_{b, t}\right\}_{t=0}^{\infty}$ resolvem o problema do banco (A.6, p. 204);

6. Dadas as sequências de preços $\left\{P_{t}, W_{t}, \pi_{t}, \tau_{t}^{k}, \tau_{t}^{h}, \tau_{t}^{\Pi^{f i r}}, \tau_{t}^{\Pi^{\text {ban }}}, R_{t}^{b c}\right\}_{t=0}^{\infty}$, alocações $\left\{H_{t}\right.$, $\left.K_{t}, \Pi_{t}^{f i r}, \Pi_{t}^{\text {ban }}, B C_{t}\right\}_{t=0}^{\infty}$, processos estocásticos $\left\{G_{t}, T_{t}, R_{t}\right\}_{t=0}^{\infty}$ e parâmetros, as sequências de alocações $\left\{B_{t}, M_{t}\right\}_{t=0}^{\infty}$ atendem à restrição orçamentária do governo $(2.58, p$. 83) e aos regimes monetário e fiscal;

7. Condições de agregação são satisfeitas;

8. Sequências de alocações e preços obedecem às restrições de market-clearing dos onze 
mercados:

$$
\begin{aligned}
Y_{t} & =C_{t}+I_{t}+G_{t} \\
H_{t} & =H_{t}^{d} \\
K_{t} & =K_{t}^{d} \\
M_{t}^{s} & =M_{t}^{f a m}+M_{t}^{\text {ban }} \\
D_{t}^{\text {fam }} & =D_{t}^{\text {ban }} \\
B_{t}^{s} & =B_{t}^{\text {fam }}+B_{t}^{\text {ban }} \\
L_{j, t} & =L_{j, t}^{d} \\
L_{e, t} & =L_{e, t}^{d} \\
L_{i, t} & =L_{i, t}^{d} \\
L_{x, t} & =L_{x, t}^{d} \\
B C_{t} & =B C_{t}^{s} ;
\end{aligned}
$$

9. Leis de movimento para os processos estocásticos $\left\{z_{t}, \mathcal{P}_{t}, z_{\mathcal{T} t}, G_{t}, T_{t}, R_{t}\right\}_{t=0}^{\infty}$ dados pelas equações (2.12), (2.40), (2.55), (2.56) e (2.59), respectivamente;

10. Condições iniciais dadas $\left\{K_{0}, M_{0}, B_{0}, \mathcal{K}_{0}, \mathcal{P}_{0}\right\}$;

11. Sequências de alocações e preços são processos estacionários.

Todas as equações de equilíbrio são apresentadas no apêndice A, seção A (p. 219).

\subsubsection{Equilíbrio Geral Competitivo de Estado Estacionário}

Esta seção descreve a obtenção de uma solução em estado estacionário para o modelo proposto. 
A existência de solução estacionária única e localmente estável para modelos de expectativas racionais é garantida pela observância das condições de Blanchard \& Kahn (1980), que foi o método utilizado para resolver o problema. Os autores delinearam condições locais necessárias e suficientes para a existência e a unicidade de uma solução de expectativas racionais em modelos estocásticos e cuja disseminação pode ser atribuída à praticidade da avaliação em termos dos autovalores computados no estado estacionário do modelo e da condição de posto completo de uma sub-matriz no bloco endógeno. Anote-se que o método, embora eficiente, guarda críticas relacionadas à arbitrariedade na seleção de variáveis em exógenas e endógenas e ao excesso de rigor na hipótese de estacionaridade de todo o sistema.

A prática na solução e análise de modelos DSGE pelos textos macroeconômicos tem estabelecido certa irrelevância no estudo do estado estacionário, pois o objetivo concentra-se na dinâmica do modelo. Daí porque esses modelos fazem uso da linearização para simplificar a calibração e a especificação de formas funcionais. É naturalmente assumido que apenas os parâmetros que governam a parte dinâmica precisam ser estimados, por simplicidade, cabendo a calibração simples dos parâmetros que definem a parte estática. A calibração de parâmetros deve buscar então a obtenção de valores coerentes para os agregados e as relações entre as principais variáveis do modelo.

Apenas alguns fechamentos foram necessários para caracterizar as soluções estacionárias do modelo, pois as equações de equilíbrio estacionário determinam endogenamente a maior parte das variáveis e razões. Ainda assim, tomou-se i) inflação $\pi=1.03 \%$, a média histórica segundo Schmitt-Grohé \& Uribe (2005); ii) relação dívida pública/produto $B / Y=70 \%$; iii) gastos do governo representando $20 \%$ do produto $^{28}$; iv) horas dedicadas ao trabalho $H=1 / 3$ da unidade de tempo da família, o que é consoante com os dados e com a literatura específica ${ }^{29} ; \mathrm{v}$ ) participação da família no crédito total $L^{j} / L=5 \%$; e vi) lucro da firma em relação ao produto

\footnotetext{
${ }^{28}$ Schmitt-Grohé \& Uribe (2005) calibram 17\% para EUA, Hall (2001) calibra 20\% para o Reino Unido, Christiano, Motto \& Rostagno (2007) calibram 20\% para EUA e 23\% para União Européia, Kanczuk (2004) calibra $18 \%$ para Brasil.

${ }^{29}$ Ver em Alencar (2002), Kanczuk (2004).
} 
igual a 12\%, como aplicam Schmitt-Grohé \& Uribe (2005), utilizando o custo fixo de produção para alcançar essa taxa.

A parte relacionada ao acelerador financeiro requereu duas calibrações que garantem a existência de external finance em estado estacionário: i) razão capital/riqueza dos emprendedores $K / N^{e}=1.02$; e ii) spread entre o retorno bruto do capital e a taxa bruta de juros livre de risco $\left(R^{k}-R\right)$ igual a 200 pontos-base. O spread tem valor aproximado ao do texto original de Bernanke, Gertler \& Gilchrist (1999), baseando-se nas médias históricas da taxa de retorno do capital e da taxa de juros dos títulos americanos, e que é seguido por diversos autores ${ }^{30}$. Por sua vez, a razão capital/riqueza é tomada pela relação riqueza/dívida das firmas $\left(N^{e} / L\right)$, que expressa a necessidade de financiamento externo. Em Bernanke, Gertler \& Gilchrist (1999) o valor é tomado igual a 1 para a economia americana (external finance de 50\%), também como Hall (2001) fez para analisar a economia britânica. A análise de McGrattan \& Prescott (2005) é mais ampla sobre o financiamento externo nas firmas, eles descobrem que a razão riqueza/dívida permaneceu relativamente estável e igual a 4.7 no período entre 1960-1995. Todavia, após 1995 a razão vem aumentando de forma considerável, alcançando 60 no ano de 2001, último ano da amostra, equivalente a um external finance de $1.64 \%$. O valor calibrado aqui representa $2.75 \%$ de financiamento externo do capital, considerando-se adequado para os dias mais recentes (razão riqueza/dívida igual a 34) ${ }^{31}$. Em verdade, para os atuais níveis de capital/produto, valores baixos da razão riqueza/dívida significam financiamento externo elevado e razão crédito/produto facilmente considerada errada diante das observações da realidade. Esse ponto é fundamental na calibração da existência de acelerador financeiro em estado estacionário.

As equações de equilíbrio de estado estacionário determinam precisamente as variáveis do setor

\footnotetext{
${ }^{30}$ Ver em Alencar (2002), Christiano, Motto \& Rostagno (2007). Levin, Natalucci \& Zakrajsek (2004) acharam 227 pontos-base, Fiore \& Uhlig (2005) encontraram 298 pontos-base e Carlstrom \& Fuerst (1997) reportam aproxidamente 187 pontos-base, valores que confirmam a boa aderência da calibração.

${ }^{31}$ Martins (2007) calcula para o Brasil e encontra 2.77 (empresas financiam $26.47 \%$ do capital), embora com uma parametrização diferente para depreciação e custos de monitoramento. Em texto recente, Christiano, Motto \& Rostagno (2007) estimam e calibram em 47.8\% para a União Européia e $11.53 \%$ para os Estados Unidos porque avaliam consistente que o financiamento bancário seja substancialmente superior na Europa.
} 
real da economia, enquanto as demais variáveis são conhecidas mediante os fechamentos acima descritos. Para uma explicação mais detalhada, ver no apêndice (B).

\subsubsection{Calibração}

Na parte em que o modelo proposto guarda proximidade com os modelos da Nova Síntese Neoclássica, por exemplo Christiano, Eichenbaum \& Evans (2005), Smets \& Wouters (2003), Schmitt-Grohé \& Uribe (2005), a parametrização é assumida equivalente. Outro conjunto de parâmetros que se referem ao acelerador financeiro do investimento foram calibrados em modelos como Fuerst (1995), Smith (1998), Bernanke, Gertler \& Gilchrist (1999), Hall (2001), Alencar \& Nakane (2004). A calibração empregada aqui considera o trimestre como unidade de tempo e é realizada para a economia norte-americana.

Vale destacar a decisão por alguns parâmetros em especial. No bloco das famílias, o parâmetro da elasticidade de substituição de consumo por moeda na função utilidade $\left(\varsigma_{3}\right)$ é tomado consistente com os modelos de Alencar (2002) e Alencar \& Nakane (2003) com moeda na função utilidade, embasado por estimações realizadas para o Brasil; e de Canzoneri et al. (2008) para a economia americana.

Pela ausência de valores para o parâmetro de depósitos bancários, optou-se por calibrá-lo com ganhos marginais de utilidade tal que a relação depósitos bancários/produto alcance 70\%, consistente com os dados para a economia americana. A calibração para títulos públicos é finalmente assumida zero para que a taxa de juros do ativo seja igual à taxa de juros livre de risco em equilíbrio.

O nível tecnológico foi assumido unitário para firmas e bancos $A=A^{\text {ban }}=1$. A demanda por crédito das firmas é motivada como fração da renda do trabalho, tal como Schmitt-Grohé \& Uribe (2005) e Christiano, Eichenbaum \& Evans (2005) fazem para a demanda por moeda das firmas. Assumiu-se a calibração dos primeiros autores, cuja necessidade de liquidez das firmas é estimada em 51\%. O investimento dos lucros das firmas foi definido em $15 \%$, a fração 
restante é transferida para as famílias. Os valores de $\gamma, \mu, \sigma_{\Phi}$ definem o contrato financeiro dos empreendedores e a calibração buscou os valores originais em Bernanke, Gertler \& Gilchrist (1999) e seguidos em textos subsequentes ${ }^{32}$.

A maioria dos parâmetros no bloco dos bancos não possui fontes na literatura que guardem a mesma especificação aqui empregada. Seguiu-se, portanto, o procedimento usual nos modelos que contém bancos, que é a calibração para representar aproximadamente algumas relações dos agregados bancários, especificamente loan-to-deposit $L / D=70 \%$ e capital próprio sobre ativos totais $\mathcal{K} /(\mathcal{K}+D)=10 \%$, consistente com dados para vários países ${ }^{33}$. O parâmetro $\nu_{3}$, que expressa ganhos de escopo na função custo do banco, foi calibrado em $0.05 \%$, em escala com os parâmetros $\nu_{1}$ e $\nu_{2}$ cuja calibração foi emprestada de Diaz-Gimenez et al. (1992).

Os parâmetros da política monetária foram calibrados ${ }^{34}$ com base em trabalhos que modelam regra de juros. A dinâmica dos choques recebeu a especificação constante em Schmitt-Grohé \& Uribe (2005). Para os ciclos de negócios no mercado banco, tomou-se a mesma medida das firmas por ausência de especificação melhor. Os choques na função pagamentos do banco também foram aproximados aos valores de persistência e variância dos choques de produtividade, bem como a calibração para a dinâmica dos choques nas elasticidades-juros da demanda por crédito que definem os mark-ups bancários em cada mercado.

A tabela 2.1 apresenta a relação completa de parâmetros calibrados.

\footnotetext{
${ }^{32}$ Martins (2007) desenvolveu a calibração e estimação para o Brasil e apontou valores razoavelmente diferentes. Os valores obtidos por Alencar (2002) também diferem da calibração original. Como parece não haver fechamento sobre tais parâmetros, mesmo para as economias americana e da união européia (CHRISTIANO; MOTTO; ROSTAGNO, 2007), ainda que a variação aconteça dentro de intervalos considerados razoáveis (CARLSTROM; FUERST, 1997), optou-se pelo texto seminal.

${ }^{33}$ http://data.worldbank.org/indicator

${ }^{34}$ Para a economia brasileira, Kanczuk (2004) encontrou que o coeficiente para o hiato do produto é não significante, o coeficiente de persistência de juros é 0.33 e o desvio-padrão da regra de juros é 5.8\%, enquanto Maziero \& Nakane (2002) estimam persistência de 0.52 e desvio-padrão $2.74 \%$. Para a economia americana, Canzoneri et al. (2008) apontam coeficiente de inflação 0.4, coeficiente de hiato do produto 0.04 e persistência de 0.8 . Para a economia britânica, Hall (2001) calibra o coeficiente da inflação igual a 0.2 e persistência de 0.9. Muinhos \& Alves (2003), por sua vez, tem dados para a economia brasileira e americana. A persistência é 0.9 nos EUA e 0.85 no Brasil e o coeficiente de inflação é 0.11 e 0.225 , respectivamente. Os valores calibrados no trabalho (persistência 0.9 , coeficiente de inflação 0.11 , coeficiente de hiato do produto 0.05 e desvio-padrão $2.5 \%$ ) estão dentro do intervalo considerado pela literatura.
} 
Tabela 2.1: Calibração de Parâmetros

\begin{tabular}{|c|c|c|c|}
\hline Variável & Descrição & Valor & Fonte \\
\hline \multicolumn{4}{|c|}{ Bloco Famílias } \\
\hline$\varsigma_{1}$ & Elasticidade de Substituição do Consumo por Lazer & 0.75 & $(\mathrm{SU})$ \\
\hline$\varsigma_{2}$ & Elasticidade de Substituição do Consumo por Moeda & 0.016 & $(\mathrm{AN})$ \\
\hline$\varsigma_{3}$ & Elasticidade de Substituição do Consumo por Depósitos & 0.001 & \\
\hline$\varsigma_{4}$ & Elasticidade de Substituição do Consumo por Títulos Públicos & 0 & \\
\hline$\beta$ & Desconto Intertemporal & 0.9902 & (SU) \\
\hline$b$ & Persistência do Hábito de Consumo & 0.65 & (SU) (CEE) \\
\hline \multicolumn{4}{|c|}{ Bloco Firmas } \\
\hline$A$ & Nível Tecnológico de Produção de Bens & 1 & \\
\hline$\alpha$ & Capital Share da Função de Produção de Bens Finais & 0.35 & $(\mathrm{SU})$ \\
\hline$\alpha_{f}$ & Probabilidade de Rigidez de Preço do Bem Intermediário & 0.6 & (SU) (CEE) \\
\hline$\chi_{f}$ & Indexação de Preços & 0 & $(\mathrm{SU})(\mathrm{CS})(\mathrm{L})$ \\
\hline$\eta$ & Elasticidade Preço da Demanda por Bens Intermediários & 6 & $(\mathrm{SU})(\mathrm{CEE})$ \\
\hline$\nu$ & Percentual de Antecipação da Folha de Salários & 0.5114 & $(\mathrm{SU})$ \\
\hline$\iota$ & Fração do Lucro revertida para Investimento & 0.15 & \\
\hline
\end{tabular}

Bloco Empreendedores e Produtores de Capital

$\begin{array}{lll}\varpi & \text { Custo Marginal de Ajustamento do Investimento } & 8 \\ \delta & \text { Depreciação do Capital } & 0.0173 \\ \sigma_{\Phi} & \text { Desvio-padrão da Distribuição do Choque Idiossincrático } & 0.28 \\ \gamma & \text { Probabilidade de Falência } & 2.7 \% \\ & \text { (continua) } & \end{array}$


Tabela 2.1: (continuação)

\begin{tabular}{llll}
\hline Variável & Descrição & Valor & Fonte \\
\hline$\mu$ & Custo de Verificação da Dívida & $12 \%$ & (BGG) \\
\hline \multicolumn{1}{c}{ Bloco Bancos } & & \\
\hline$A^{\text {ban }}$ & Nível Tecnológico de Produção de Crédito & 1 & \\
$\alpha_{b}$ & Participação dos Depósitos na Tecnologia Bancária & 0.9 & \\
$\beta_{b}$ & Participação do Capital Próprio na Tecnologia Bancária & 0.1 & (D) \\
$\nu_{1}$ & Custo Marginal do Depósito Bancário & 0.0011875 & (D) \\
$\nu_{2}$ & Custo Marginal do Empréstimo Bancário & 0.005625 & \\
$\nu_{3}$ & Ganho de Escopo de Empréstimos e Depósitos & 0.0005 & \\
$\theta_{x}$ & Elasticidade Juros da Demanda por Crédito Interbancário & 50 & \\
$\eta_{1}$ & Coeficiente da Função Pagamentos & 0.5 & 0.97 \\
$\iota^{\text {ban }}$ & Fração do Lucro dos Bancos distribuída às Famílias & 0.05 & \\
$\omega$ & Depreciação do Capital Próprio dos Bancos & & \\
\hline
\end{tabular}

\section{Política Monetária e Fiscal}

$\mu_{\pi} \quad$ Coeficiente das Expectativas de Inflação na Regra de Taylor $\quad 0.11$

$\mu_{Y} \quad$ Coeficiente do Hiato do Produto na Regra de Taylor $\quad 0.05$

$\tau^{h} \quad$ Alíquota de Imposto sobre o Trabalho $\quad 0.30$

$\tau^{k} \quad$ Alíquota de Imposto sobre o Capital $\quad 0.40$

$\tau^{\Pi^{f i r}} \quad$ Alíquota de Imposto sobre Lucros das Firmas $\quad 0.15$

$\tau^{\Pi^{b a n}} \quad$ Alíquota de Imposto sobre Lucros dos Bancos $\quad 0.15$

Choques

$\rho_{z} \quad$ Persistência do Choque Tecnológico na Produção de Bens $\quad 0.8556$ (continua) 
Tabela 2.1: (continuação)

\begin{tabular}{|c|c|c|c|c|}
\hline Variável & \multicolumn{2}{|c|}{ Descrição } & Valor & Fonte \\
\hline$\rho_{z_{\mathcal{T}}}$ & \multicolumn{2}{|r|}{ Persistência do Choque Tecnológico na Produção de Crédito } & 0.8556 & \\
\hline$\rho_{\mathcal{P}}$ & \multicolumn{2}{|c|}{ Persistência do Choque de Pagamentos } & 0.85 & \\
\hline$\rho$ & \multicolumn{2}{|c|}{ Persistência de Juros da regra de Taylor } & 0.9 & (MA) \\
\hline$\rho_{G}$ & \multicolumn{2}{|c|}{ Persistência do Gasto Público } & 0.87 & $(\mathrm{SU})$ \\
\hline$\rho_{T}$ & \multicolumn{2}{|c|}{ Persistência das Transferência do Governo } & 0.78 & $(\mathrm{SU})$ \\
\hline$\rho_{\theta}$ & \multicolumn{2}{|c|}{ Persistência no Choque de Elasticidade Juros da Demanda } & 0.9 & \\
\hline$\sigma_{z}$ & \multicolumn{2}{|r|}{ Desvio-padrão do Choque Tecnológico na Produção de Bens } & 0.0064 & $(\mathrm{SU})$ \\
\hline$\sigma_{z_{\mathcal{T}}}$ & \multicolumn{2}{|r|}{ Desvio-padrão do Choque Tecnológico na Produção de Crédito } & 0.0064 & \\
\hline$\sigma_{\mathcal{P}}$ & \multicolumn{2}{|c|}{ Desvio-padrão do Choque de Fluxo de Pagamentos do Banco } & 0.005 & \\
\hline$\sigma$ & \multicolumn{2}{|c|}{ Desvio-padrão do Choque de Juros } & 0.005 & \\
\hline$\sigma_{G}$ & \multicolumn{2}{|c|}{ Desvio-padrão do Choque de Gastos do Governo } & 0.016 & $(\mathrm{SU})$ \\
\hline$\sigma_{T}$ & \multicolumn{2}{|c|}{ Desvio-padrão do Choque de Transferências } & 0.022 & $(\mathrm{SU})$ \\
\hline$\sigma_{\theta}$ & \multicolumn{2}{|c|}{ Desvio-padrão do Choque de Elasticidade-Juros da Demanda } & 0.005 & \\
\hline \multirow[t]{8}{*}{ Fontes: } & (SU) & Schmitt-Grohé \& Uribe (2005) & & \\
\hline & $(\mathrm{CEE})$ & Christiano, Eichenbaum \& Evans (2005) & & \\
\hline & (BGG) & Bernanke, Gertler \& Gilchrist (1999) & & \\
\hline & $(\mathrm{AN})$ & Alencar \& Nakane (2003) & & \\
\hline & (D) & Diaz-Gimenez et al. (1992) & & \\
\hline & $(\mathrm{CS})$ & Sbordone \& Cogley (2004) & & \\
\hline & $(\mathrm{L})$ & Levin et al. (2005) & & \\
\hline & (MA) & Muinhos \& Alves (2003) & & \\
\hline
\end{tabular}




\subsection{Resultados}

O procedimento seguinte é calcular a solução de equilíbrio do modelo DSGE utilizando técnicas computacionais para aproximar as regras de decisão em equações lineares. O software utilizado foi o Dynare (http://www.dynare.org/), versão 4.1.3. As equações foram imputadas em nível, para as quais foi solicitada ao software a linearização em primeira ordem no desenvolvimento do método de solução. As saídas do aplicativo são muitas e incluem, entre elas, o cálculo dos autovalores do sistema; momentos teóricos e decomposição da variância, aplicando o filtro Hodrick \& Prescott (1997) com $\lambda=1600$, consistente com dados trimestrais; matriz de correlações e de autocorrelações; e regras de decisão. Algumas saídas estão tabuladas no apêndice $(\mathrm{B})$.

Algumas relações de estado estacionário estão apresentadas na tabela (2.2). Em geral, as razões têm escala coerente com os dados observados para diversos países na atualidade. O ajuste fino aos valores reais de uma dada economia é apenas uma questão de sintonia dos parâmetros do modelo.

Tabela 2.2: Relações de Estado Estacionário

\begin{tabular}{lrlr}
\hline \multicolumn{2}{c}{ Setor Real } & \multicolumn{2}{c}{ Setor Bancário } \\
\hline Variável & Valor & Variável & Valor \\
\hline$C / Y$ & 0.62 & $L / Y$ & 0.40 \\
$I / Y$ & 0.18 & $D / Y$ & 0.65 \\
$K / Y$ & 10.33 & $\mathcal{K} / L$ & 0.14 \\
$N^{e} / L^{e}$ & 51.25 & $\mathcal{K} /(D+\mathcal{K})$ & 0.08 \\
$\Pi^{\text {fir }} / Y$ & 0.12 & $M^{\text {ban }} / D$ & 0.38 \\
$\left(R^{k}\right)^{4}-1$ & $12.49 \%(*)$ & $B^{\text {ban }} / D$ & 0.09 \\
& (continua) & & \\
\hline
\end{tabular}


Tabela 2.2: (continuação)

\begin{tabular}{lrrr}
\hline \multicolumn{2}{c}{ Setor Real } & \multicolumn{2}{c}{ Setor Bancário } \\
\hline Variável & Valor & Variável & Valor \\
\hline$\left(R^{b}\right)^{4}-1$ & $4.00 \%(*)$ & $\left(R^{d}\right)^{4}-1$ & $3.61 \%(*)$ \\
$\pi^{4}-1$ & $4.20 \%(*)$ & $\Sigma^{4}-1$ & $10.17 \%(*)$ \\
\hline
\end{tabular}

(*) Valores anualizados.

Os artigos atuais ${ }^{35}$ dispensam maiores explicações e análises sobre o estado estacionário, bastando a conformidade aproximada com as relações econômicas. Isso acontece porque são as propriedades dinâmicas o foco de pesquisa, normalmente a comparação com os resultados de modelos da família VAR. Todavia, o objetivo da tese não é o mero fitting de dados, mas a conexão dos conceitos apresentados e sobre os quais se fundamenta a hipótese de trade-offs.

\subsubsection{Propriedades Estáticas}

A análise empregada nesta seção é a estática comparativa dos estados estacionários de economias definidas pela modificação de apenas um parâmetro estrutural.

Seja o parâmetro $\beta$ do modelo, o fator que desconta o tempo para as famílias e que afeta diretamente a substituição intertemporal do consumo, conforme a equação de Euler (2.6, p. 51). Em estado estacionário, a taxa de juros livre de risco é o inverso do fator de desconto. A impaciência com relação ao futuro define a taxa básica de juros da economia. O parâmetro $\beta$ fundamenta, portanto, a taxa básica de juros, donde derivam outras conexões com a economia real e com o setor financeiro.

\footnotetext{
${ }^{35} \mathrm{~A}$ análise de correlações e relações estáticas era um exercício comum em artigos de outros tempos. Modernamente a análise essencial está na dinâmica dos modelos e na capacidade explicativa para a dinâmica que é observada nos dados econômicos e mensurada por modelos autorregressivos. A partir daí, com a inclusão de rigidezes, que alteram bastante as relações estáticas, a análise estática teria apenas um papel figurante, dispensado na maioria dos artigos atuais.
} 
O exercício compara economias com fatores de desconto diferentes. No setor real, taxas básica de juros menores ( $\beta$ maiores) explicam taxas de investimento maiores. Consumo, investimento e produto são maiores e, como a oferta de trabalho é igual em todas as economias, o salário real é superior, o que lidera maior demanda por crédito das firmas.

Economias com taxas de juros mais baixas têm maior estoque de capital e maior riqueza líquida, dada a relação de estado estacionário. Mas o preço do capital é menor porque os juros afetam o fator de desconto dos produtores de capital. O valor do estoque de capital a ser financiado tem o gráfico na forma de $\mathrm{U}$ invertido: é superior para alguns $\beta \mathrm{s}$, mas para taxas de juros ainda mais baixas, o efeito preço supera o aumento do estoque de capital. Isso explica porque a demanda de crédito acompanha a forma de $\mathrm{U}$, apesar do colateral maior. $\mathrm{O}$ formato da curva de crédito ao empreendedor acaba desenhando a forma da curva de crédito total da economia.

O fator de desconto intertemporal do banco é ainda maior pela dinâmica de incorporação de lucros ao capital bancário. A capitalização e o capital bancário são maiores em estado estacionário. Os depósitos bancários são maiores por vários motivos: i) a taxa de juros mais baixa significa maior poupança das famílias; ii) o custo de oportunidade do colchão de liquidez é menor; iii) a tecnologia bancária admite volume maior de depósitos porque a demanda de crédito e o capital bancário são superiores, portanto há oportunidade de ganhos acima da taxa básica, mas o lucro marginal do crédito é cada vez menor porque capital e depósitos bancários, enquanto fatores de produção, têm rendimentos decrescentes; e iv) ganhos de escala no custo operacional. Demanda e oferta de crédito são maiores, mas a taxa de juros sobre depósitos bancários de equilíbrio é menor.

O custo marginal de produção de crédito $\Sigma$ é menor porque i) o custo de oportunidade dos títulos públicos é menor; ii) o custo marginal do crédito é menor, embora aumente com $\beta$ s muito altos; iii) os ganhos de escopo são maiores; e iv) o lucro marginal do crédito é menor. Entretanto as taxas de juros em cada mercado de crédito têm curvas diferentes. As taxas no crédito às famílias e empreendedores são menores, o que é esperado, entretanto os juros reais para o crédito às firmas são maiores. A explicação pode ser encontrada na condição de primeira 
ordem para o fator trabalho ( eq. (2.19), p. 54), uma vez que a demanda de crédito é uma fração da folha de salários. O salário real é maior porque o consumo é maior e as horas de trabalho são as mesmas para as economias de estado estacionário, então o lazer fica mais caro, conforme a equação de oferta de trabalho. Do lado da firma, a produtividade do fator trabalho é ainda maior, porque o estoque de capital é maior e as horas trabalhadas são as mesmas. A renda da firma proporcionada por ganhos de produtividade maiores que o salário real por unidade de trabalho é extraída pelo setor bancário em competição monopolística. Em outras palavras, a elasticidade-juros da demanda das firmas é menor.

A figura (2.1) calcula os indicadores propostos para essa estática comparativa. Os gráficos estão organizados em três colunas: a primeira contém indicadores de eficiência microeconômica, a segunda mostra os indicadores de resiliência financeira e a terceira coluna contém gráficos relacionados à Macroeconomia.

Sob a perspectiva macroeconômica, $\beta$ s maiores e taxas de juros menores são benéficos para a economia por liderarem aumento de todos os componentes da demanda agregada, o que é explicado por maior poupança e menor consumo em termos relativos ao produto. Há mais oferta de depósitos bancários, enquanto o volume de crédito é maior até certo ponto, quando a partir daí $\beta$ s maiores definem menor crédito. Isso acontece porque o financiamento externo diminui em relação às economias de taxas de juros mais elevadas por dois motivos: i) o colateral é maior e ii) o preço do capital menor suplanta o efeito do aumento do estoque, reduzindo em termos absolutos o valor do projeto de investimento. A taxa de inflação mantida igual em estado estacionário acompanhada de taxas de juros menores explicam maior retenção de saldos monetários, porque o custo de oportunidade também é menor. Aumentos absolutos de consumo, moeda e depósitos bancários garantem que as economias mais pacientes têm maior bem-estar, sob o conceito de utilidade instantânea ${ }^{36}$.

\footnotetext{
${ }^{36}$ Faz sentido aqui analisar a utilidade corrente de estado estacionário ao invés da utilidade esperada de estado estacionáriodescontada no tempo por conta de uma peculiaridade matemática. A função utilidade é medida em logaritmo e apresenta valores negativos para argumentos menores que 1. Em estado estacionário, $\beta$ maior significa menor desconto de utilidades negativas e menor utilidade esperada. Por outro lado, ao comparar duas economias $\operatorname{com} \beta$ s diferentes, a economia de famílias pacientes ( $\beta$ maior) tem utilidades correntes comparativamente maiores do que a economia de famílias impacientes em todos os períodos de tempo.
} 

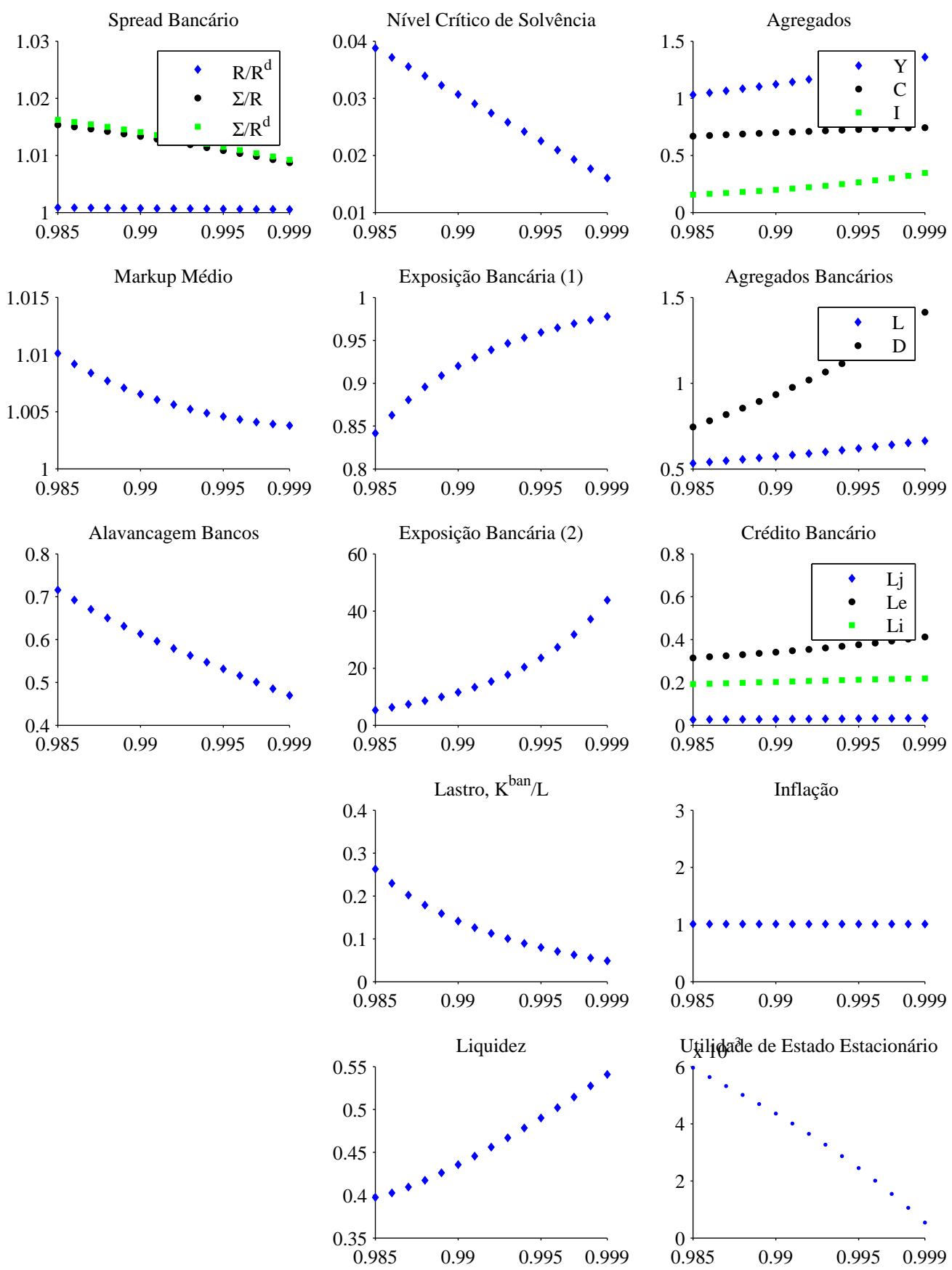

Figura 2.1: Estática comparativa - Taxa de juros dos títulos públicos 
Sob a ótica da resiliência financeira, contudo, as economias com taxas de juros menores terão um setor bancário menos resiliente a eventos de instabilidade financeira. É possível assim afirmar pela congruência semântica apresentada pelos indicadores da estrutura do balanço patrimonial do banco. Do ponto de vista da qualidade do crédito, o financiamento externo menor explica porque empreendedores trabalham com nível de solvência inferior quando a taxa de juros é baixa e por isso a perda bancária é menor para custos de monitoramento iguais. O tamanho do sistema bancário é maior, pois depósitos e capital bancários são ambos superiores, todavia a relação entre eles é diferente. Nas economias com taxas de juros menores, os depósitos bancários aumentam mais do que o capital bancário, até porque têm produtividades marginais diferentes. O aumento relativo do endividamento bancário afeta a resiliência financeira porque aumenta a exposição do banco às instabilidades do passivo, quando, afora as causas do estresse, os depositantes executam os seus recursos junto ao sistema.

Os índices de Exposição revelam que (1) a composição do endividamento (fração dos recursos bancários que tem maior exigibilidade do que o estoque de capital bancário) é superior com taxas de juros menores; e (2) a razão de recursos de terceiros sobre recursos próprios é menor, o que indica menos garantias bancárias ao depositante. Concordando com maior exposição, o lastro bancário para as operações de crédito é menor em economias com juros mais baixos. $\mathrm{O}$ capital bancário serve como garantia aos depositantes da qualidade da administração bancária na oferta de crédito. Quando os juros são baixos, o volume de crédito aumenta mais que o capital bancário. Por sua vez, taxas menores de juros indicam sistema financeiro trabalhando com maior liquidez. É razoável pensar que os bancos estão sob retornos marginais decrescentes nos depósitos, razão pela qual a captação de recursos é maior do que a demanda por crédito, liderando reservas voluntárias maiores de moeda e títulos públicos. Em suma, as medidas da segunda coluna direcionam à mesma conclusão. A síntese é que as economias com taxas menores se apresentam menos resilientes a instabilidades financeiras. Observe que isso não sugere que tais economias estejam mais suscetíveis à instabilidade, porque os índices não revelam causa, apenas indicam maiores dificuldades nos recursos do banco para tratar crises, dada a suposição de que estresses financeiros existem. Acrescente-se ainda que maior ou menor resiliência de 
facto depende sobretudo das características da instabilidade financeira.

Agora pela perspectiva da eficiência microeconômica, menores taxas de juros livres de risco significam taxas de juros de depósitos e custo marginal bancário mais baixos. Os spreads de captação e de oferta diminuem, fazendo também menor o spread total. Nesse sentido, o banco opera com taxas mais próximas à taxa livre de risco e isso indica menos ineficiência do setor bancário na intermediação financeira. Isso à parte, sobre o custo marginal bancário incidem os mark-ups de cada setor, que existem porque há falhas de competição. Como já foi explicado, as taxas de juros finais para famílias e empreendedores são menores, mas firmas têm taxas maiores. O mark-up médio ponderado para economias com $\beta$ s maiores é sempre menor, apesar de as taxas de juros do crédito às firmas serem maiores. O que acontece é que a demanda de crédito dos empreendedores é mais sensível à mudança e aumenta a participação setorial no agregado.

Por último, a alavancagem mede a oferta de crédito realizada com o volume de depósitos bancários. É um indicador de produtividade do fator depósitos, maior alavancagem significa menos depósitos necessários para ofertar crédito. Não obstante, a alavancagem também pode medir resiliência financeira, porque representa um indicador de liquidez do sistema bancário. Ceteris paribus, alavancagem maior significa que o banco mantém menos ativos líquidos, como moeda e títulos públicos. Da mesma forma, o lastro que é medida de resiliência também é indicador de produtividade do fator capital bancário. Maior lastro significa menos produtividade, todavia mais estabilidade financeira. Portanto, é intrínseco a esses dois índices o trade-off entre resiliência financeira e eficiência microeconômica. A análise estática aponta que as taxas de juros menores explicam mais depósitos bancários, ao passo que a demanda de crédito também aumenta para taxas muito baixas. Em equilíbrio, a alavancagem do sistema é menor, trazendo duas interpretações: i) as economias de juros menores têm menor produtividade no uso de depósitos bancários para gerar crédito; ii) todavia possuem relativamente mais liquidez no sistema bancário. A síntese para os indicadores é aguda na hipótese de maior eficiência bancária para economias com taxas de juros menores. 
A análise empregada acima é válida, embora seja importante apressar duas considerações. A primeira é reconhecer o caráter comparativo comportamental do exercício, que permite a observação e explicação dos conceitos apresentados e mostra como há uma interação entre eles, contidos que estão em um mesmo ambiente econômico integrado. Todavia este exercício tem limitada capacidade de generalização das conclusões. Como antes sugerido, o objetivo é simplesmente observar as propriedades do estado estacionário.

A segunda observação refere-se ao parâmetro escolhido e sua natureza comportamental. Ainda que os canais de transmissão estejam expostos, a ligação direta entre o parâmetro e as taxas de juros, instrumento de política monetária, é uma prerrogativa do estado estacionário. A alteração de um parâmetro estrutural não é objeto de política econômica de curto prazo. As recomendações de políticas sempre perseguidas na leitura de textos macroeconômicos não serão oferecidas pela análise estática.

\subsubsection{Propriedades Dinâmicas}

Nesta seção é apresentada a dinâmica do modelo linearizado mediante a análise qualitativa de funções de resposta a impulso. São analisadas as respostas ótimas para i) choque contracionista de política monetária; e ii) choque de produtividade na tecnologia de produção de bens finais. O objetivo principal é verificar como os mecanismos de transmissão monetários e de inovações tecnológicas interagem com os conceitos de eficiência, resiliência financeira e estabilização macroeconômica.

\subsubsection{Choque de Política Monetária}

O modelo econômico de equilíbrio desenvolvido neste capítulo 2 explicou as diversas interações entre os agentes econômicos, com especial representação do mercado bancário. No contexto geral, já são bem conhecidos alguns canais de transmissão, mas a incorporação das fricções financeiras deriva mecanismos outros para a permeabilidade dos choques de política monetária sobre a economia real. Algumas observações merecem destaque inicial: 
1. O canal tradicional de taxa de juros está associado às condições de equilíbrio da economia, garantem que a taxa de juros do título público é uma taxa sem risco e tal derivação permite a atuação de políticas de juros (“monetárias”), mesmo em economia sem moeda, atuando diretamente sobre o desconto intertemporal da família. Os impulsos de política monetária afetam diretamente o consumo, principal componente da demanda agregada, porque altera a decisão de poupança das famílias. Entretanto, segundo se verifica nos dados, a depressão do consumo apresenta alguma resistência, geralmente capturada nos modelos pela fricção real de formação de hábitos de consumo. A visão de crédito da política monetária, em contraposição à visão de moeda, interessa-se pela análise dos efeitos de política monetária na alocação dos ativos em poder da família, donde se deduz o potencial explicativo de fricções financeiras.

2. O canal conhecido como "balance sheet" está relacionado ao efeito riqueza nos ativos dos empreendedores. Quando as alterações não antecipadas de política monetária alteram o valor presente do investimento, que está sujeito a custos de ajustamento, o preço da capital muda, portanto. O efeito preço altera o valor do estoque de capital dos empreendedores. Como a riqueza corrente é colateral na decisão de financiamento bancário, os empreendedores estarão sob novas condições do contrato financeiro com os bancos.

3. $\mathrm{O}$ acelerador financeiro pode ser analisado como um efeito riqueza intertemporal e acontece porque os choques de política monetária afetam preço e retorno esperados do capital, com desvios sobre a riqueza líquida esperada e o colateral do período seguinte.

A literatura tem ponderado com alguma insistência que os efeitos do canal de " $b a$ lance sheet" e do acelerador financeiro amplificam os choques monetários, como em Bernanke, Gertler \& Gilchrist (1999) e Iacoviello (2008). Todavia esses modelos consideram que o crédito é tomado diretamente no mercado sem fricções, assinalam Gerali et al. (2010), o que é bem distante da caracterização das firmas bancárias na moderna 
teoria de banking.

A efetividade do canal de empréstimos bancários no Brasil foi alvo de diversos estudos. Takeda, Rocha \& Nakane (2003) analisam os impactos de política monetária sobre depósitos e crédito, utilizando valores do balanço patrimonial dos bancos brasileiros. Os resultados do modelo VAR mostram que a política monetária efetivamente altera os agregados bancários. Enquanto os recolhimentos compulsórios induzem a queda dos depósitos, políticas de juros aumentam os depósitos bancários, mas fazem cair as operações de crédito livres. Graminho \& Bonomo (2002) encontram, em contrário, que políticas contracionistas de juros reduzem a sensibilidade do crédito bancário em relação ao passivo total porque relaxam as restrições de liquidez, pelo que refutam o crédito bancário como um mecanismo efetivo de transmissão de política monetária no Brasil. Os trabalhos de Sobrinho \& Nakane (2002) e Sobrinho (2003) avaliaram todavia que os canais de crédito são ativos no país porque a política monetária afeta preços e quantidades, mas principalmente a velocidade do crédito. Os estudos reconhecem entretanto que conclusões definitivas sobre a operação do canal de crédito requerem a análise de microdados de crédito.

Outros mecanismos de propagação da política monetária podem ser identificados no mercado bancário. O detalhamento de fricções na captação de recursos, operação produtiva e oferta de crédito acrescentam explicação e o chamando "canal de crédito"

4. Efeito liquidez: mudanças na taxa de juros alteram a decisão intertemporal de poupança, mas afetam também a alocação relativa entre os ativos. As demandas por moeda, depósitos bancários e títulos públicos estão associadas ao spreads entre a taxa básica de juros e as respectivas taxas que remuneram os ativos. Especificamente, o pass-through da taxa de juros para o custo de oportunidade da moeda é maior do que sobre o custo de oportunidade de manter depósitos bancários e títulos públicos, ao que se acrescente que ambos os ativos remunerados a juros também oferecem serviços transacionais, o que advoga pela amplificação dos efeitos contracionistas, com aumento relativo de depósitos e títulos sobre moeda. 
5. O choque de política monetária tem efeitos também sobre a decisão de capitalização dos bancos, a substituição intertemporal do lucro do banco. Se a política for contracionista, diminui o valor do futuro para os bancos, mas em escala superior ao desconto estocástico das famílias, uma vez que os lucros não são acumulados integralmente ao capital bancário. A capitalização interna que transfere lucro presente para formação de capital é reduzida. Menos capital significa menos recursos disponíveis para empréstimo. Essa é uma versão do bank lending channel $^{37}$ para o capital bancário mediante instrumento de juros. No modelo, além da restrição do balanço do banco, a redução é amplificada pela tecnologia bancária.

6. As ações de política monetária também afetam as respostas ótimas do banco. Especificamente, o choque contracionista de política monetária aumenta a rentabilidade dos títulos públicos e, portanto, altera diretamente o ganho de emprestar recursos e o custo de oportunidade do crédito ao setor privado. As taxas de juros de depósitos e do crédito devem acompanhar o movimento, mas o pass-through do choque é determinado pelo comportamento ótimo do banco. O canal de custos pode ser sintetizado em três elementos: i) na captação de recursos de terceiros, aumenta o custo de oportunidade de manter liquidez de parte dos depósitos e aumenta o custo operacional do depósito bancário, ambos reduzem a propagação do choque; ii) ganhos de escopo são maiores com volumes administrados menores, o que aumenta a propagação do choque; iii) custo operacional do crédito maior, porque a escala de produção é menor, ampliando o choque sobre o custo marginal do crédito.

7. O banco capta depósitos bancários mas a tecnologia do banco permite apenas parcialmente a transformação dos recursos em crédito. Em outras palavras, o volume de de-

\footnotetext{
${ }^{37}$ Tradicionalmente, o canal de empréstimos bancários é descrito para depósitos bancários. Na impulsão de uma política monetária contracionista sobre as reservas bancárias, por exemplo, reduz o volume de recursos emprestáveis do banco. Generalizando a ideia, a transmissão do choque ocorre em conjunto com a retração dos passivos bancários.
} 
pósitos captado de forma livre seria insuficiente para atender à exigência do banco na composição do seu passivo, a restrição tecnológica é binding. Para atender a demanda total do crédito privado, o banco deve captar depósitos adicionais, cujo preço-sombra é $\lambda_{2}$. A depressão da demanda total de crédito implica que a tecnologia do banco fica menos restritiva e o preço do depósito adicional cai, reduzindo a propagação do choque sobre a taxa de juros dos depósitos e sobre o custo marginal do crédito bancário. As depressões da demanda por crédito e do capital bancário não têm efeitos lineares porque a tecnologia implica em alguma substitutabilidade entre os fatores. Em geral, o estoque de capital é menos exposto a variações absolutas, razão pela qual é o capital próprio quem se torna relativamente mais produtivo em relação ao depósito bancário.

A substituição técnica imperfeita entre depósitos e o capital bancário atende à condição para existência do canal de crédito ativo. De fato, sob variações negativas nos recursos coletados de terceiros, é desejável supor que o banco tenha dificuldades para substituir aqueles recursos, de tal maneira que o repasse à oferta de crédito seja direto. $\mathrm{O}$ banco no modelo básico paga o capital próprio com o seu próprio lucro, reduzindo sua função objetivo. A capitalização interna é um meio de constituir capital próprio reduzindo o lucro corrente. O banco usa esse mecanismo garantido que as perdas no lucro instantâneo sejam compensadas pelos ganhos de ter um estoque de capital maior. Em outras palavras, o banco tem o poder de ajustar de maneira ótima o seu estoque de capital de acordo com o fluxo intertemporal de lucros.

A transmissão da política monetária é analisada mediante os gráficos de respostas ótimas a um choque contracionista não antecipado. Ver a figura (2.2). A taxa de juros dos títulos públicos aumenta em um desvio-padrão, o que equivale a 50 pontos-base. A taxa de juros de estado estacionário é de 990 pontos-base.

O modelo de média escala com detalhamento para o funcionamento dos bancos não altera a direção das respostas ótimas das principais variáveis macroeconômicas. Não por acaso, o papel dos bancos é de promotor, ao invés de diretor, da atividade econômica. As fricções financeiras 

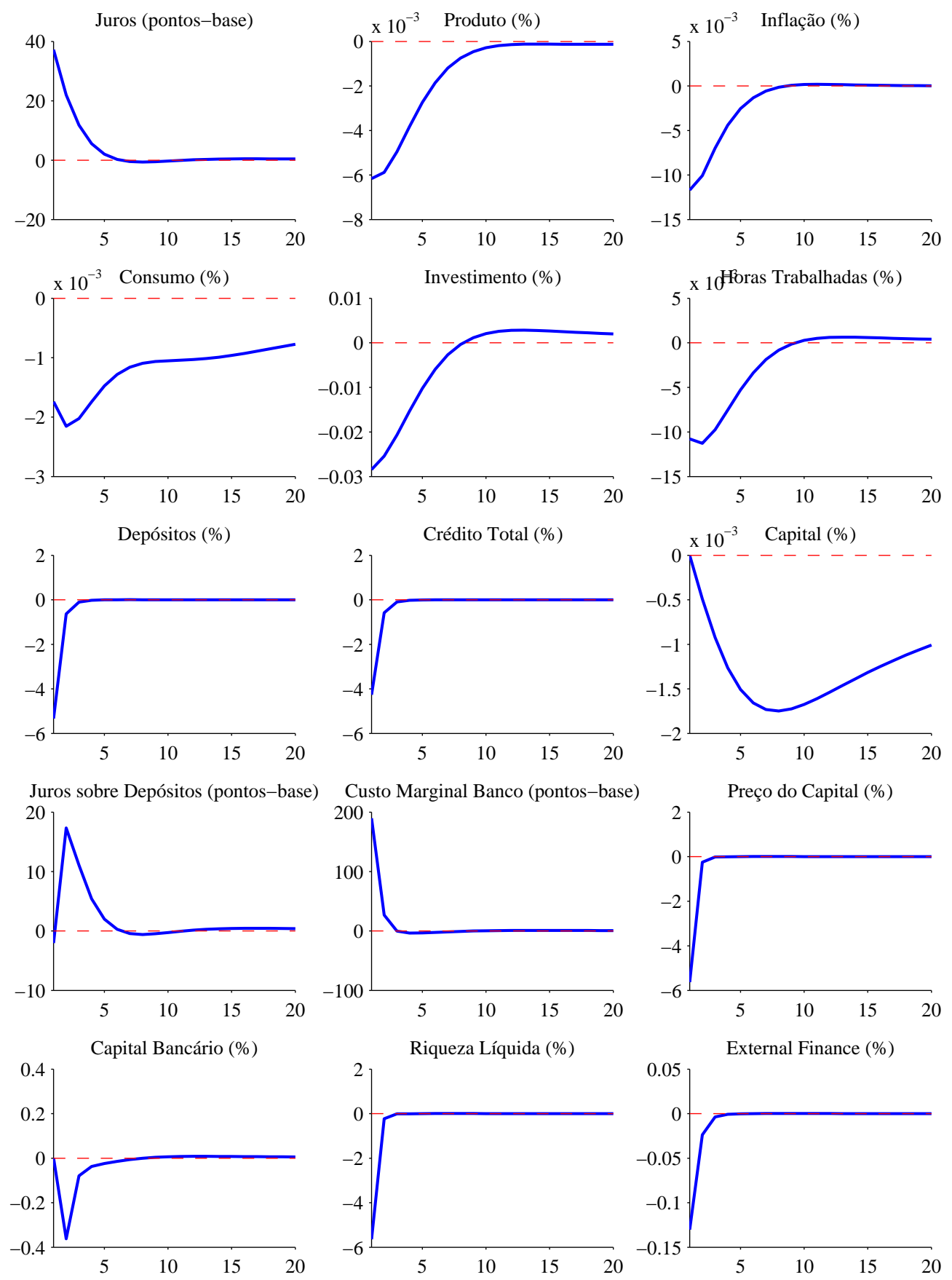

Figura 2.2: Respostas ótimas da economia a choque contracionista de política monetária. 
quando incorporadas a modelos macro têm a missão de propor explicações para os problemas de timing, magnitude e composição dos efeitos de política monetária quando comparados à observação dos dados. A vantagem dos modelos mais detalhados é desenvolver as conexões entre o lado real e financeiro da economia sem abdicar da coesão com os fatos estilizados apontados pela Teoria dos Ciclos Reais de Negócios. De forma diferente, o objetivo do modelo aqui estudado é principalmente analisar o comportamento do setor financeiro por observar como as medidas conceituais se movimentam, inclusive sob choques monetários, então o fitting de dados e as contribuições explicativas à política monetária têm inicialmente um papel coadjuvante nesta tese.

A política econômica restritiva de juros faz declinar o produto, o consumo e a inflação nos períodos seguintes, embora em magnitudes diferentes e distantes do tamanho do choque monetário. Apesar de o choque implicar maior alocação proporcional de poupança em relação ao consumo, a queda na renda do trabalho explica a redução de ativos.

Há se de destacar que a resposta da inflação é de queda proporcional à intensidade do choque contracionista. Não se observa qualquer aumento da inflação, indicando efetividade da regra de juros para controlar o nível de $\operatorname{preços}^{38} 39$ 40. Do ponto de vista do modelo apresentado, o bloco de oferta agregada explica a inflação como endógena e decorrente do problema da escolha intertemporal de firmas sob rigidez de preços. Ora, choques contracionistas de política monetária alteram o desconto intertemporal dos lucros, a resposta da firma é a escolha do preço ótimo menor uma vez que o horizonte de perda está mais restrito.

\footnotetext{
${ }^{38}$ Normalmente encontra-se price puzzle nas análises de modelos autorregressivos. Segundo Sims (1992), a existência de price puzzle está relacionada à atuação da autoridade monetária. O governo responde de forma sistemática às expectativas de inflação futura, mas não suficiente para evitar aumento dos preços correntes. O resultado é que aumentos de taxa de juros seriam seguidos por aumentos na inflação e essa correlação está associada a falhas na capacidade de identificar choques exógenos nas taxas de juros do governo. Sims (1992) sugere que a autoridade monetária tem mais informação sobre a inflação futura do que explicam os modelos VARs. Outra explicação é a de que a autoridade monetária reage a choques de oferta mediante políticas contracionistas, mas sua atuação não é suficiente no sentido de suprimir as consequências inflacionárias, liderando aumento de preços

${ }^{39} \mathrm{O}$ price puzzle traz a discussão de que a autoridade monetária poderia estar sob ponderação maior para a estabilidade de produto em detrimento da estabilidade de preços. Na ocorrência de choques de produtividade, se o peso da estabilidade de preços é maior, o banco central reage de forma peremptória, reduzindo o price-puzzle.

${ }^{40}$ Cysne (2004) mostra que o price puzzle existe nos dados brasileiros, mas seu efeito é "insignificante temporal e quantitativamente": apenas um trimestre e com magnitude inferior a 3.2\%, com desvio padrão em torno de 0.28.
} 
Os empréstimos de firmas e empreendedores também caem porque a demanda desses mercados está associada ao valor da renda do trabalho e ao preço do capital, respectivamente.

As taxas de juros do crédito bancário aumentam menos, cerca de 15 pontos-base, do que aumentou a taxa de juros do governo. Isso acontece porque o custo marginal do banco aumentou menos e os mark-ups apenas repassam seus efeitos às taxas finais. Em detalhe, o aumento do custo de oportunidade do crédito foi atenuado pelos efeitos do canal de custo do banco: i) apesar de os custos operacionais do crédito estarem menores, os ganhos de escopo são maiores, ambos em razão do nível de produção; e ii) o efeito principal contrário é a redução do custo de atender a tecnologia bancária, porque os fatores depósito e capital aumentam em produtividade e menos depósitos são necessários para atender uma demanda de crédito deprimida. Portanto, o pass-through das taxas de crédito é imperfeito. Por outro lado, a taxa de juros do depósito bancário acompanha a taxa de juros básica, o que indica que os efeitos do canal de custos, do custo de oportunidade e da tecnologia se anulam e nenhum ruído é imposto no mercado de depósitos.

A resposta do capital bancário é negativa porque a redução das margens explica redução do resultado bancário, os lucros futuros estão menos importantes, então o banco reage reduzindo a capitalização, deprimindo o capital bancário. No geral, o impacto é muito persistente, donde se extrai que a participação do capital próprio dos bancos na propagação do choque monetário é um mecanismo importante e promissor para análises futuras. A tecnologia de produção acrescenta convexidade entre depósitos e capital bancário, a resposta observada é a atenuação do choque monetário, indicando algum efeito substituição relevante no retorno das variáveis ao estado estacionário.

Em geral, os resultados do setor bancário indicam atenuação dos efeitos do choque monetário, destacando o pass-through imperfeito da taxa de juros instrumento de política para as taxas de juros do crédito. Em verdade, dois fatores explicam a fricção: i) a formação do custo marginal bancário contém elementos contracíclicos, como custos operacionais (apesar de que os ganhos de escopo são pró-cíclicos) e custos tecnológicos; e ii) a competição monopolística 
de produtos diferenciados implica em mark-ups que propagam e amplificam os efeitos sobre o custo marginal do crédito: no caso da política monetária restritiva, o custo marginal do banco aumenta em menor proporção e as taxas finais repassam o aumento com alguma amplificação, na medida do mark-up.

Aqui, ao contrário de Gerali et al. (2010), o capital bancário tem importância para explicar os efeitos contracíclicos, uma vez que ambos os fatores tornam-se mais produtivos quando a escala é menor, liderando custos menores para atender a demanda por crédito. Como será analisado adiante, os movimentos na taxa básica de juros determinam sensível alteração na estrutura de ativos e passivos do banco.

Os resultados estão em sintonia com aqueles obtidos por modelos que incluem fricções financeiras e setor bancário.

Christiano, Motto \& Rostagno (2007) argumentam que, em geral, bancos e fricções financeiras fortalecem significativamente o canal de crédito na propagação monetária, mas o modelo desenha mercado bancário perfeitamente competitivo. Eles concordam com Gerali et al. (2010) no sentido de que os bancos tem um papel apenas coadjuvante na transmissão do choque monetário porque os efeitos sobre a riqueza líquida e sobre o acelerador financeiro são mais relevantes. Não é essa a conclusão desta seção, aqui as fricções bancárias explicam mais a propagação do que a riqueza líquida, apesar de que o mecanismo acelerador financeiro potencializa os efeitos sobre financiamento externo, não por conta do colateral, mas pela persistência do spread entre as taxas de retorno do capital e os juros do crédito.

O efeito geral das fricções bancárias percebido na análise da transmissão do choque monetário é de alguma atenuação da retração e são as alterações na dinâmica do passivo bancário que afetam a oferta de crédito e geram o repasse incompleto. Em comparação generalista com Goodfriend \& McCallum (2007), os resultados concordam com os efeitos de atenuação, explicados por eles como impactos sobre os custos marginais do banco. Gerali et al. (2010) também encontram efeitos contracíclicos importantes para as fricções bancárias porque as taxas bancárias têm 
rigidez de preços na existência de custos de ajustamento, como também existem custos para o banco por desviar de uma meta na razão capital próprio/crédito (aqui definida como lastro, que é o índice induzido pela regulação prudencial). Os autores encontram efeitos atenuadores similares nos trabalhos de Aslam \& Santoro (2008) e Andrés \& Arce (2009).

A análise dos índices que representam os conceitos propostos nesta tese é realizada pela observação de funções de resposta a impulso. O layout dos gráficos segue o padrão iniciado na análise das propriedades estáticas: a primeira coluna de gráficos elenca as medidas relacionadas à eficiência bancária, a segunda coluna contém as medidas de resiliência financeira, enquanto a terceira coluna analisa propriedades macroeconômicas, ainda que tenham sido detalhadas na figura anterior. Observe a figura (2.3).

A observação do conjunto de gráficos da terceira coluna e a análise empregada acima já permitem concluir que o choque monetário retrai as principais variáveis macroeconômicas. A estabilidade econômica é alcançada após a dispersão do choque, com o retorno às condições estacionárias após alguns períodos. A maior persistência está associada ao investimento da economia: uma combinação dos canais de balance sheet e do acelerador financeiro, principalmente, com os canais de transmissão bancários via juros explicam os efeitos sobre o financiamento externo vários períodos após o choque. O papel verificado das fricções bancárias foi a atenuação dos efeitos iniciais, em um pass-through incompleto da perturbação monetária.

Em termos de resiliência financeira, é possível afirmar que o choque monetário restritivo impõe menor exposição financeira na economia. Primeiro, porque a qualidade do crédito melhora, resultado do financiamento externo nos projetos de investimento, que perdura por vários períodos. Apesar de a riqueza líquida recuperar de forma rápida, vinculada à recuperação do preço do capital (na verdade, em última instância, pela rápida acomodação aos custos de ajustamento), o financiamento externo tem persistência porque a acomodação do custo do crédito aos níveis estacionários é mais lento. Nesse sentido, o acelerador financeiro é relevante, apesar de não estar tão vinculado ao balance sheet do empreendedor. 

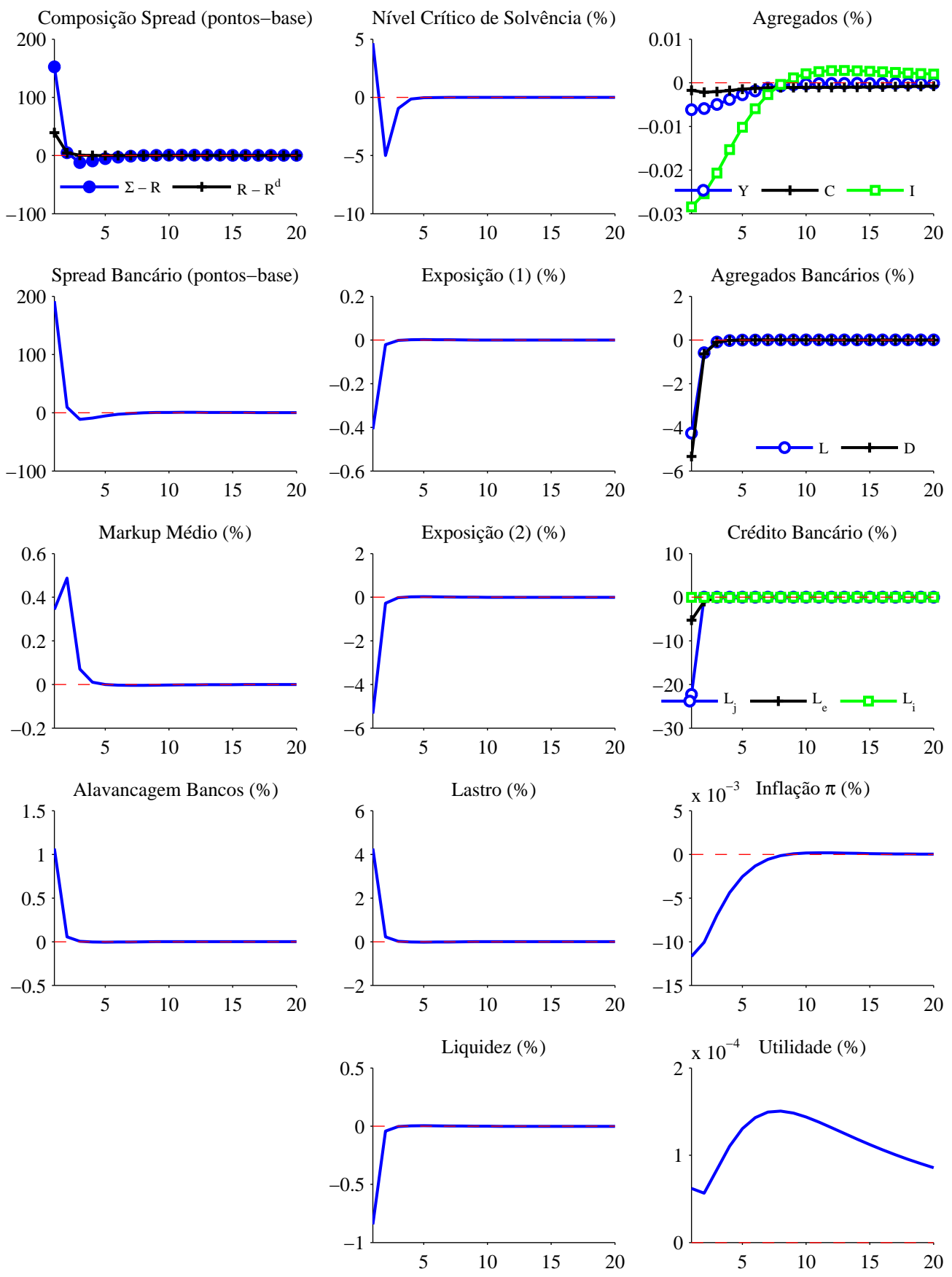

Figura 2.3: Respostas ótimas da economia a choque contracionista de política monetária indicadores conceituais 
Em segundo lugar, o choque monetário restritivo implica em queda do nível dos depósitos bancários e do capital próprio do banco. O efeito geral mostra que a repressão sobre os depósitos bancários é maior do que aquela percebida no capital bancário (donde se induz o efeito substituição permitido pela tecnologia bancária). O tamanho dos bancos é menor. A estrutura do passivo bancário apresenta menor exposição porque i) os recursos de terceiros que possuem maior exigibilidade caem relativamente ao tamanho do banco; e ii) há mais capital próprio garantindo os depósitos bancários, esse efeito é quantitativamente mais importante do que o primeiro. Por fim, o crédito total da economia é afetado relativamente mais do que o capital do banco, havendo portanto mais capital próprio lastreando os ativos de crédito, outra medida de resiliência. Em termos de garantias aos depositantes, o banco trabalha sob nível de liquidez menor relativamente, isso porque o crédito é reduzido menos do que o passivo do banco. Em verdade, as taxas de juros elevadas objetivam reprimir o crédito, e realmente o faz, o que indicaria mais reservas voluntárias do banco. Isso não acontece porque i) as taxas também reduzem os recursos para o banco; e ii) com recursos mais escassos, predomina os ganhos de eficiência produtiva da concessão de crédito. A variação do índice de liquidez, todavia, é tímida.

A eficiência do setor bancário também percebe mudanças no curto prazo provocadas pela perturbação monetária. De fato, o incompleto pass-through de política monetária significa, por outra perspectiva, que os spreads do banco estão inicialmente menores. Especificamente, a margem sobre a oferta de crédito é menor e explicada pela redução no custo de adquirir depósitos para atender a tecnologia bancária. Isso porque a queda na escala de produção significa custos operacionais menores e a substitutabilidade entre depósitos e capital bancário minora o efeito do choque monetário. Durante poucos períodos os bancos vão operar com taxas de juros e custo marginal absolutamente maiores, mas relativamente mais próximos, até que resposta do capital bancário reduza os efeitos iniciais. A acomodação lenta do capital bancário em relação à persistência do choque monetário explica a inversão, quando a economia opera com spreads maiores.

Sobrinho \& Nakane (2002) encontram, de forma empírica, analisando dados de concessão de crédito, que o choque contracionista de política monetária faz com que os bancos reduzam a 
oferta de crédito e os spreads são maiores.

Nesse sentido é que se qualifica como ganhos de eficiência iniciais do setor, tendo como paradigma o resultado não friccional em que as taxas de juros coincidem. O mark-up médio tem alteração inicial mas não persistente. A alavancagem bancária aumenta porque a depressão dos depósitos é maior do que a percebida no crédito. Como medida de eficiência, mais crédito é ofertado por unidade de depósito bancário. Como medida de resiliência, o crédito ofertado está menos associado aos depósitos bancários portanto, pela definição do balanço do banco, mais vinculado ao capital bancário, como já mensurado pela medida de lastro.

Em resumo, observou-se que o pass-through da política monetária é incompleto. Duas implicações são imediatas: i) quanto à magnitude, o esforço monetário necessário para impor efeitos reais deve ser majorado levando em conta que as fricções dos canais de crédito contém perdas na intensidade; e ii) quanto ao timing, os efeitos sobre o bloco bancário e sobre o bloco de investimento não se dissipam tão rapidamente, o que indica maior tempo até o retorno das condições estacionárias. Em parte, o ajustamento lento está relacionado ao movimento do estoque de capital bancário. Portanto, as fricções financeiras tornam o instrumento de política monetária menos efetivo ${ }^{41}$. A estabilidade macroeconômica delegada à política monetária também fica prejudicada, pois há dificuldades de recuperação das variáveis reais após choques monetários. Em tempo, pondere-se que a regra de juros da economia possa estar inadequada para lidar com efeitos menores e mais persistentes explicados pelas fricções financeiras.

Outras conclusões vêm da interação com a área que estuda a instabilidade financeira. Ao permeabilizar o choque monetário pelas vias do crédito, o mercado bancário altera sua estrutura de passivos e ativos. O choque contracionista lidera a redução no tamanho do mercado e direciona a menor exposição bancária porque os bancos estão mais capitalizados em termos relativos.

\footnotetext{
${ }^{41}$ A literatura contém textos favoráveis e contrários a esse ponto de vista. Concordam com o efeito atenuador Gerali et al. (2010), Aslam \& Santoro (2008), Andrés \& Arce (2009) e Goodfriend \& McCallum (2007). Modelos que não descrevem o mercado bancário de forma explícita, portanto sob menos rigidezes, encontram amplificação dos efeitos, como Bernanke, Gertler \& Gilchrist (1999), Iacoviello (2008) e Diamond \& Rajan (2006). Goodfriend \& McCallum (2007) mostram que ambos os efeitos estão modelados, mas a prevalência atenuadora têm significância quantitativa.
} 
Sobre a escolha dos ativos, a razão entre o crédito e os ativos totais é menor porque relativamente a demanda por moeda para pagamentos é maior, ou seja, os bancos passam a operar sob maior liquidez. Desse modo, o distúrbio monetário é acompanhado de bancos menores e relativamente menos expostos, portanto, mais resilientes a certas instabilidades financeiras, ao que se pondere que houve alguma perda de liquidez do sistema. Do ponto de vista da eficiência microeconômica, o que é prejuízo para a efetividade do canal de crédito, por outro lado, representa a melhor eficiência produtiva: a tecnologia do banco. Spreads inicialmente menores e maior produtividade dos fatores depósito bancário e capital próprio explicam o repasse imperfeito de choques contracionistas como sendo ganhos de eficiência na oferta de crédito. Políticas monetárias expansionistas, em contrário, imporão menor eficiência ao setor bancário porque há rendimentos decrescentes nos fatores de produção, resultando em spreads maiores na oferta de crédito que serão ainda ampliados pela imperfeição competitiva do mercado de crédito.

Existem trade-offs sim na reunião dos conceitos de eficiência microeconômica, resiliência financeira e estabilidade macroeconômica sob o ponto de vista qualitativo na análise dos choques de política monetária. 


\subsubsection{Choque de Produtividade}

Também a análise da transmissão do choque de produtividade tecnológica é feita pela observação qualitativa das funções de resposta a impulso geradas pelas equações de equilíbrio do modelo linearizado. A figura (2.4) mostra como a economia reage ao choque de um desviopadrão na produtividade total de fatores das firmas produtoras de bens intermediários.

O choque tecnológico faz a produção de bens mais eficiente, implicando em custos marginais, preço ótimo e inflação menores. O salário real aumenta, explicando também a maior necessidade de crédito das firmas. A política monetária atua de forma expansionista para acomodar a queda da inflação, com efeitos similares sobre as taxas de juros de depósitos e o custo marginal bancário. São as condições mais favoráveis de juros que explicam o aumento do crédito total. Com retorno do capital maior e crédito mais barato, o balance sheet do empreendedor e o acelerador financeiro explicam o financiamento externo crescente, liderando aumento do investimento da economia, com efeitos durante vários períodos. Em verdade, é o investimento o motor do crescimento da demanda agregada, o efeito sobre o consumo é relativamente mais baixo. O choque amplia o investimento inicial, elevando o estoque de capital de uma só vez, enquanto ao longo do período o ajustamento indica menores investimentos e o empreendedor tomando crédito para manter o estoque elevado de capital.

Os depósitos bancários são impulsionados pelo crescimento da renda. Em contrapartida, o capital bancário cai porque os spreads bancários estão menores e direcionam menor acumulação de lucros. Aqui, novamente, insinua-se algum efeito substituição entre capital próprio e depósitos bancários. A queda no capital do banco apresenta alguma persistência relacionada à redução dos spreads ao longo do tempo. Os custos operacionais relacionados aos depósitos são menores e o custo do colchão de liquidez também é menor diante da reação dos juros do governo. O efeito sobre a oferta de depósitos bancários é bem maior do que crescimento da demanda por crédito e, por tal razão, não são percebidos efeitos sobre o custo tecnológico. A substitutabilidade entre capital bancário e depósitos não afeta o custo de obter depósitos adicionais 

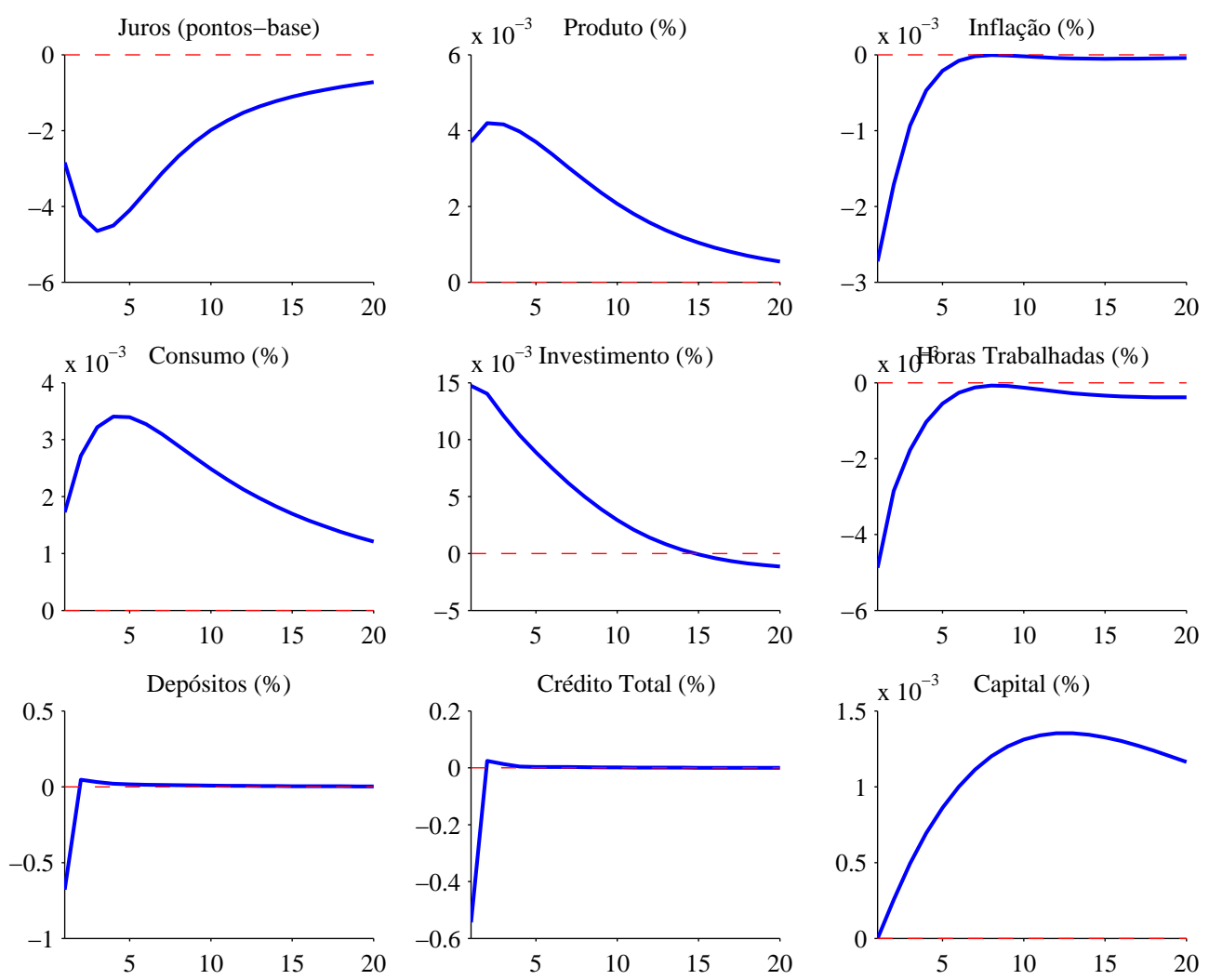

Juros sobre Depósitos (pontos-base)
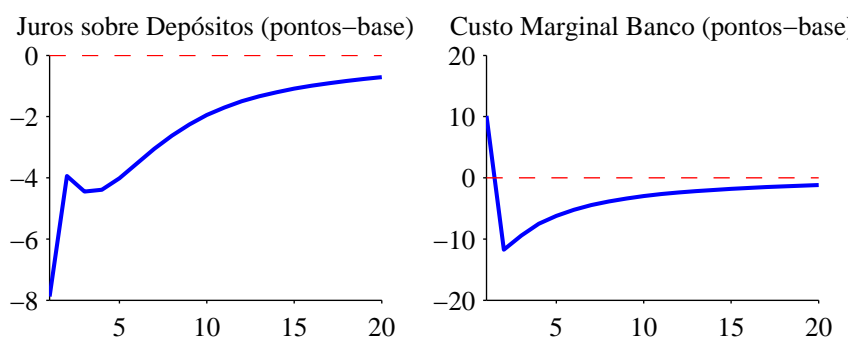

Preço do Capital (\%)
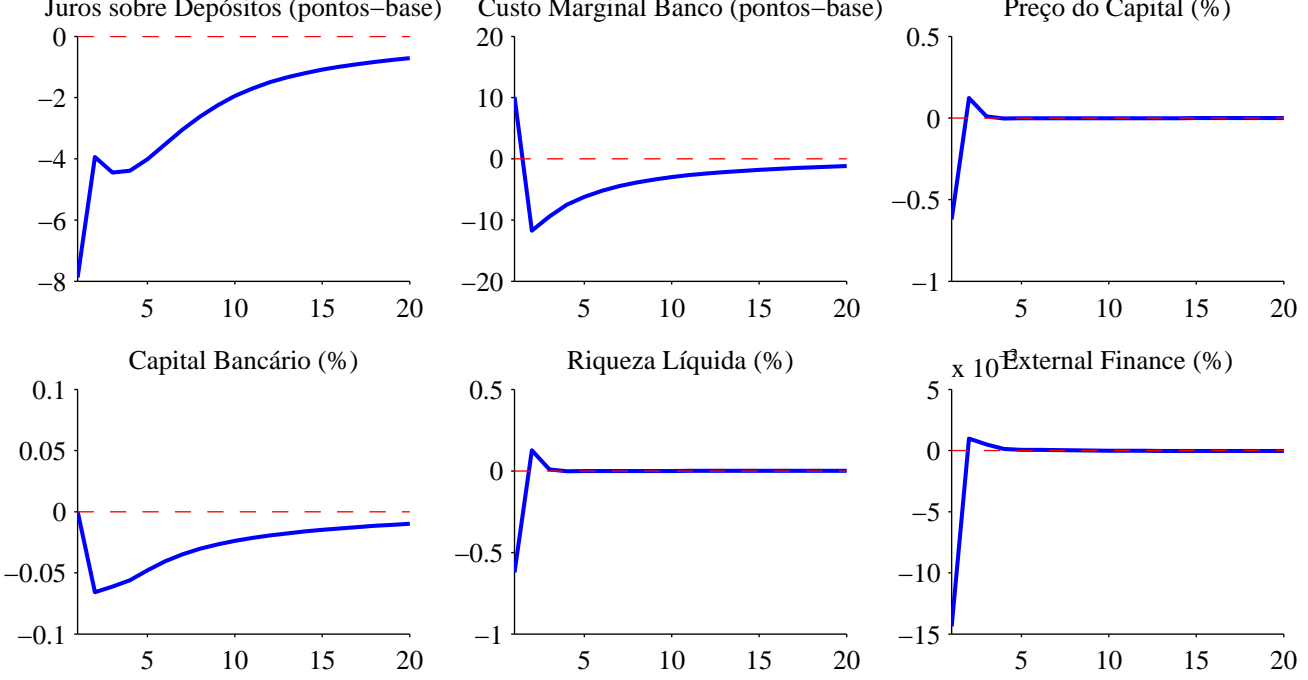

Figura 2.4: Respostas ótimas da economia a choque na produtividade total de fatores. 
para atender a demanda de crédito. Assim, as taxas de juros sobre os depósitos acompanham as taxas de juros do governo. O custo marginal bancário também acompanha o ritmo da queda do título público. Os mark-ups amplificam a queda do custo marginal para as taxas finais de juros do crédito.

Os efeitos do choque tecnológico são amplificados em intensidade e no tempo pela atuação da taxa de juros, especificamente pela persistência dos juros na resposta ao choque tecnológico. É esta característica que obriga taxas de juros mais baixas mesmo quando o retorno do capital já está em níveis estacionários que promove o financiamento externo e o acelerador financeiro. Abrem-se oportunidades para o empreendedor, que não é explicada pela riqueza líquida, como normalmente se presumiria, mas pelo diferencial de juros e as oportunidades de retorno.

Do ponto de vista dos trade-offs, o exercício tem algumas conclusões. Ver na figura (2.5) o comportamento dos indicadores conceituais nas respostas ótimas ao ganho de produtividade.

Sob a ótica macroeconômica, o choque tecnológico representa aumento de produto e, portanto, aumento das rendas. Não apenas os componentes da demanda agregada respondem positivamente, mas a demanda de crédito e os depósitos nos bancos são maiores. Uma observação está na persistência dos efeitos: enquanto a demanda agregada rapidamente absorve o choque, os agregados bancários têm persistência elevada. A explicação está na atuação da autoridade monetária, que amplifica os efeitos porque constrói um spread superior ao estado estacionário entre o retorno do capital e os juros do crédito; mas também na existência do acelerador financeiro, que amplia o financiamento externo na presença do spread favorável. Pode-se interpretar que o investimento é realizado de maneira íngreme, até pela existência dos custos de ajustamento. O estoque de capital é mantido maior durante vários períodos por meio do mecanismo de financiamento externo que acelera a capacidade de processamento de capital do empreendedor. Consumo e ativos acima do nível de estado estacionário, explicam porque a utilidade esperada tem tendência crescente.

O efeito acelerador atua para alavancar a capacidade investidora do empreendedor, ainda que 

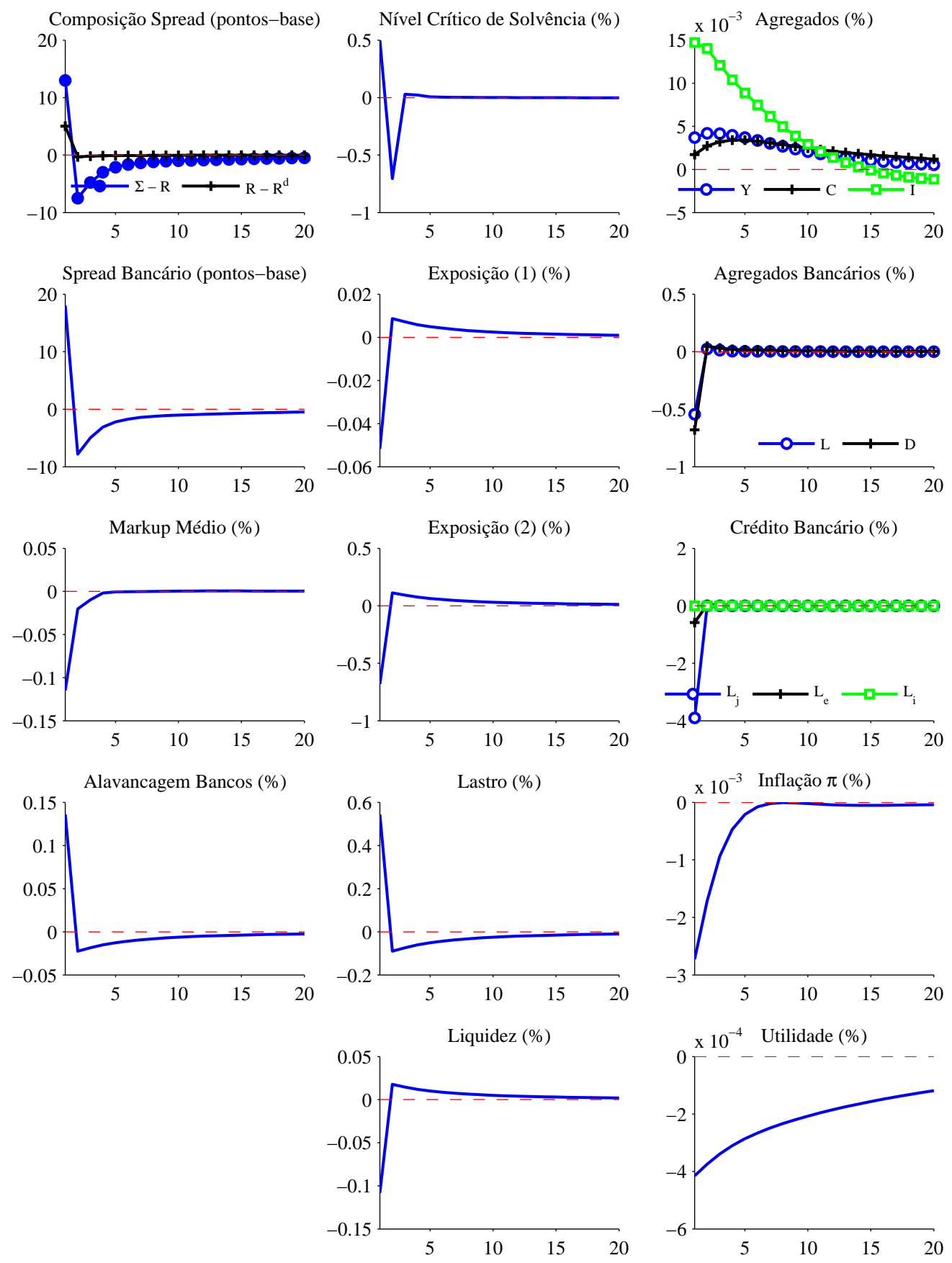

Figura 2.5: Respostas ótimas da economia a choque na produtividade total de fatores - indicadores conceituais 
o nível de colateral não apresente persistência ${ }^{42}$. Isso faz com que o nível crítico de solvência aumente, indicando menor qualidade do crédito bancário ${ }^{43}$. Os indicadores de exposição bancária indicam que o efeito sobre os depósitos bancários é maior do que no capital bancário, liderando maior exposição sustentada pela persistência da taxa básica de juros. O cenário de capital bancário menor e crédito em expansão refletem a diminuição do lastro do sistema bancário. Também os bancos agora operam sob regime de maior liquidez, porque a maior captação de depósitos bancários não é totalmente aplicada em crédito, aumentando as reservas bancárias de liquidez. Enquanto o lastro bancário menor reduz em termos absolutos e relativos as garantias reais para os depositantes, o índice de liquidez apresenta garantias melhores na administração dos ativos bancários. Todavia, o primeiro efeito tem intensidade superior e concorda com os índices anteriores. Portanto, a resposta do sistema bancário transcorre mediante a deterioração das medidas de resiliência financeira e com alguma persistência liderada pela condução monetária.

Os spreads têm oscilação tímida e suavemente negativa nos períodos de acomodação do choque. A abundância de depósitos bancários supera a queda do capital próprio e quase que nenhum efeito desta oscilação é repassado às taxas de juros, que acompanham estreitamente a tendência da taxa básica. O mark-up médio também não apresenta persistência, apenas oscilação inicial gerada pela variação nas participações dos mercados de crédito. A alavancagem dos bancos é menor, indicando que o efeito do choque sobre os depósitos bancários é realmente o componente determinante das respostas ótimas. Até o crescimento da oferta de crédito não é suficiente para aumentar a alavancagem do sistema e os bancos operam sob produtividade do fator depósitos é relativamente menor. As variações na eficiência microeconômica são amenas e pouco conclusivas, ainda que apontando efeito inicial de ineficiência do setor bancário.

Os trade-offs que se colocam na transmissão do choque de oferta estão relacionados à resiliência financeira e à medida de estabilização macroeconômica. A regra de juros tem papel

\footnotetext{
${ }^{42}$ Nesse caso, é o canal bank lending, não o balance sheet do empreendedor, que comanda o efeito acelerador.

${ }^{43}$ Apenas no primeiro período o nível crítico de solvência cai, em razão do efeito do colateral sobre a decisão de crédito.
} 
amplificador e pró-cíclico ao induzir o investimento inicial elevado, formando capital físico que é financiado durante vários períodos. Nesse sentido, a reação macroeconômica estabilizou o produto e a inflação e utilizou o canal de crédito com efetividade para promover efeitos dinâmicos persistentes. A manutenção de taxas baixas no crédito induz o financiamento externo, enquanto as taxas baixas para os depósitos induz a pertinácia de recursos de terceiros para o banco, ao mesmo tempo que cai o capital bancário. A movimentação do passivo mostra que a situação envolve piora nas condições de exposição, na qualidade do crédito e no lastro das operações do sistema bancário.

As principais contribuições em modelagem empenhadas nesta dissertação foram: i) a manutenção e composição com as fricções financeiras de várias das features tradicionais dos novos modelos macroeconômicos que sintetiza as contribuições da literatura novo keynesianda e de ciclos reais e abre espaço para receber mais contribuições; ii) a especificação do modelo em escala média com a descrição operacional das firmas bancárias e o tratamento da organização da indústria, em uma abordagem de produção de crédito e intermediação financeira; iii) a inclusão de capital bancário como fator de produção em uma função de produção de crédito que torna o passivo bancário não homogêneo do ponto de vista da estabilidade financeira; iv) a descrição de um problema explícito de maximização intertemporal de lucros para os bancos, que permite obter condições de ótimo interpretáveis em termos de eficiência e garante a capacidade de o problema receber novas ferramentas; v) a modelagem de fricções de tecnologia e de liquidez de pagamentos, que determinam endogenamente a reserva de liquidez e a demanda por moeda; vi) o mecanismo de capitalização dos bancos que permite a acumulação dos lucros, em uma abordagem de contabilidade bancária.

Em síntese, os resultados do modelo de equilíbrio geral apresentado no capítulo desenvolvem a interação entre os conceitos de eficiência microeconômica no mercado bancário, a segurança financeira indicada pela estrutura patrimonial do banco e estabilidade macro que advém da capacidade de a política monetária atuar para controlar os preços e incitar movimentos desejados na demanda agregada. Sob o ponto de vista representado pelo equilíbrio de estado 
estacionário, o exercício comparou economias que possuem menor taxa de juros. Os agregados macroeconômicos são comparativamente maiores, mas é em termos do trade-off entre resiliência e eficiência que se observa a lógica do modelo. As economias mais desenvolvidas possuem menores spreads e mark-ups, seus bancos são maiores, têm mais liquidez, todavia são menos capitalizados. Com menores taxas de juros, a alocação de depósitos bancários é maior no longo prazo e explica os resultados sobre a produção bancária e sobre a estruturação do passivo bancário.

Em termos dinâmicos, a interação entre os conceitos é reconhecida na análise das fricções bancárias e dos canais de crédito da transmissão monetária. O papel das fricções financeiras mostrou-se atenuador, liderando um pass-through imperfeito do choque monetário pelos canais de crédito. O comportamento dos bancos é alterado pelo choque, o capital bancário ajusta-se menos do que os depósitos e isso implica ganhos de produtividade dos depósitos bancários, refletindo na precificação do custo marginal bancário. As mudanças no passivo indicam que os bancos ficam menores, mas relativamente mais capitalizados em relação ao estado estacionário. Na visão de eficiência, a depressão dos fatores de produção e alguma substituição percebida entre depósitos e capital próprio aliam-se ao ajustamento diferenciado ao choque. Os ganhos de eficiência implicam em spreads timidamente menores, mas suficientes para garantir que o pass-through não é completo.

No escopo da tese este capítulo contribuiu para fundar as bases para a análise em equilíbrio geral de políticas econômicas sobre agregados, preços e relações do mercado bancário, oferecendo um framework modular e de grande flexibilidade e capacidade explicativa dos impactos de curto e longo prazos. Em particular, buscou-se representar a realidade da interconexão dos conceitos específicos a três áreas de estudo que é promovida no mercado bancário. O capítulo seguinte analisa algumas intervenções particulares do Estado sobre o setor, ações essas que são aparente e inicialmente justificadas por apenas um dos conceitos apresentados, mas, como já visto, devem gerar repercussão não desprezível em outras perspectivas de observação. 


\section{Capítulo 3}

\section{OS TRADE-OFFS NAS INTERVENÇÕES SOBRE O MERCADO BANCÁRIO}

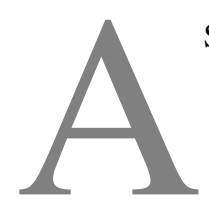

S INTERVENÇÕES DO ESTADO sobre os mercados financeiros são várias na conjuntura atual $^{1}$ e estão baseadas em objetivos principais diferentes, os quais esta tese classificou em três conjuntos conceituais: eficiência microeconômica, resiliência financeira e estabilidade macroeconômica.

Pelo menos três razões podem advogar em favor da hipótese de insciência ou inobservância da interação dos conceitos: i) o escopo institucional que, em geral, confere a organização do sistema financeiro a uma instituição central que congrega as autoridades monetária, prudencial e concorrencial; ii) os ciclos econômicos põem um objetivo sobressalente aos demais, liderando ações e ferramentas particulares; iii) a falta de teorias convergentes e ferramentas práticas de análise multiconceitual não cataliza a atenção para efeitos de equilíbrio geral.

O horizonte das intervenções do Estado também encomenda algumas ponderações. Enquanto as ações sobre a regulação técnica e a regulação prudencial buscam afetar a estrutura dos mercados, as ações de estabilidade macro concentram-se nas variações de curto prazo $^{2}$ que buscam

\footnotetext{
${ }^{1}$ Ver Barth, Caprio \& Levine (2005), Allen \& Gale (2000), Barth, Caprio Jr. \& Levine (2006) e Degryse, Kim \& Ongena (2009) para comparações internacionais.

${ }^{2}$ Especificamente para a política monetária, o princípio de neutralidade da moeda no longo prazo é preservado na maioria dos modelos da Nova Síntese Neoclássica.
} 
suavizar ciclos econômicos. Não significa, contudo, que os problemas de coordenação estejam descartados. Por um lado, as mudanças na estrutura de concorrência ou mesmo nos parâmetros de regulação prudencial podem ter característica transitória, como choques nos mark-ups bancários. Por outro, os trade-offs podem mesmo ser qualificados no tempo econômico, como escolhas entre melhores propriedades estruturais em detrimento das dinâmicas de ajustamento a choques.

O presente capítulo estuda algumas das políticas econômicas tradicionalmente aplicadas ao mercado bancário e tem o propósito de analisar a interação entre os conceitos apresentados. São desenvolvidos exercícios de estática comparativa e dinâmica de ajustamento a choque monetário dentro de um modelo de equilíbrio geral que congrega tais conceitos. Não foram localizados na literatura textos que desenvolvam tal análise, dentro do escopo multidisciplinar proposto, para instrumentos de intervenção sobre o mercado bancário - esta uma das contribuições do capítulo.

O modelo permite analisar um amplo conjunto de instrumentos de intervenção, mas aqui serão desempenhadas três importantes restrições, representativas para a pergunta da tese. Os instrumentos escolhidos guardam cada qual uma associação primária a um dos objetivos de intervenção: i) Charter Values são objetos de regulação técnica na constituição de barreiras à entrada; ii) os recolhimentos compulsórios são instrumentos tradicionais de política monetária; e iii) os requerimentos de capital são fundamentalmente a principal restrição prudencial que se recomenda aos sistemas financeiros. Cada intervenção é construída analiticamente em extensão ao modelo básico do capítulo 2, de forma não acumulativa. As análises omitem os pormenores técnicos e operacionais e são compendiosas em comparação às realizadas anteriormente. 


\subsection{Charter Value}

A indústria bancária é pesadamente regulada nas principais economias mundiais ${ }^{3}$. A entrada de firmas no mercado depende de autorização central para funcionamento que é concedida após a análise de critérios técnicos, por exemplo, capital inicial para abertura da firma. A barreira à contestabilidade do mercado impede que novas firmas gerem duas externalidades na economia: i) tomadores de crédito em geral teriam mais variedades de produtos e, portanto, aumentariam sua demanda por crédito - uma externalidade positiva; e ii) bancos entrantes geram externalidade negativa sobre a demanda intermediária dos bancos já existentes. As barreiras à entrada limitam a competição, garantem acesso privilegiado aos produtos diferenciados existentes e geram rendas de monopólio. As rendas vêm prioritariamente do spread sobre o custo marginal do crédito; contudo, em consequência da não separabilidade entre depósitos e créditos, a falha de competição repercute também sobre os custos do depósito bancário.

O requerimento de capital de entrada está associado a custos de eficiência microeconômica. A principal razão para que as autoridades técnicas criem tal impedimento é que a livre entrada e saída de firmas é indesejada porque as externalidades têm custos econômicos diversos, associados tanto à estabilidade como à qualidade setorial. Especificamente no caso dos bancos, repercute-se que tais externalidades sejam maiores do que para firmas tradicionais e vazem de forma mais ampla e intensa para outros setores da economia.

A determinação de barreiras à entrada para o mercado de bancos é uma ação regulatória, cuja justificativa de existência está fundada no trade-off entre eficiência microeconômica e custos de externalidades das instabilidades financeiras. É uma ação estrutural, não transitória. Por dificuldades na apuração dos custos econômicos e sociais das instabilidades, cujas causas sequer são adequadamente teorizadas, a medida ótima das restrições à competição é amplamente discutível.

\footnotetext{
${ }^{3}$ Uma grande e recente compilação de como os sistemas financeiros nacionais estão organizados e como são regulados está no conjunto de trabalhos de Barth, Caprio \& Levine (2000), Barth, Caprio \& Levine (2001), Barth, Caprio \& Levine (2002).
} 
O Charter Value é a denominação específica para o valor dos lucros futuros trazidos a valor presente. Lucros positivos no longo prazo são possíveis e explicados por falhas de competição. Mesmo em competição monopolística, os lucros do mercado bancário serão nulos na ausência de barreiras à entrada e rigidezes de preços. Portanto, o valor do Charter Value no longo prazo é a medida de lucros utilizada pelos bancos na decisão de entrada no mercado. Firmas entram e contestam o mercado até o ponto em que o Charter Value seja igual ao custo de requerimento de capital de entrada.

Estudos específicos relacionam o Charter Value aos incentivos do banqueiro na tomada de riscos e argumentam que a constituição de lucros para os bancos implica em menos riscos assumidos pelos administradores. A razão é aparentemente simples: sob Charter Value, os bancos têm a garantia de percepção dos lucros apenas se sobrevivem ao longo do tempo e a oferta de empréstimos arriscados aumenta a possibilidade de falência. Demsetz, Saidenberg \& Strahan (1996) mostram que o valor do Charter Value do banco é um importante componente para explicar os custos da falência, constituindo um incentivo para a adoção de políticas prudentes na tomada de riscos. Keeley (1990) e Galloway, Lee \& Roden (1997) concordam com o papel disciplinador, no sentido que os bancos sob moral hazard melhoram a administração dos riscos de crédito. Essa argumentação, todavia, não está representada no modelo proposto, mas cabe aqui apenas para acrescentar outra justificativa pela qual a autoridade regulatória deslocaria o mercado da eficiência microeconômica.

No modelo básico não há Charter Value, pois os lucros do banco são nulos em estado estacionário. O mecanismo de capitalização interna funciona para que as firmas constituam o capital bancário na ausência de acumulação de lucros. O banco escolhe o nível de capitalização de forma consistente com o fluxo dos lucros, determinando o nível ótimo de capital de acordo com a tecnologia bancária de produção de crédito. Na presença de choques, os lucros variam no curto prazo e os bancos ajustam o valor da capitalização de maneira que a alocação de capital bancário seja ótima no tempo e nas condições do mercado. A existência de lucros no curto prazo que serão parcialmente incorporados ao capital bancário no período seguinte definem que o custo de capitalização interna é reduzido, com efeitos sobre os spreads e sobre a dinâmica 
da economia, conforme foi discutido no capítulo anterior. O mecanismo de capitalização é um procedimento para garantir a existência de capital bancário na ausência de lucros econômicos.

Permitir ao mercado bancário a constituição de lucros terá, portanto, efeitos sobre o mecanismo de capitalização interna, sobre a dinâmica de ajuste ao choque monetário e sobre o nível ótimo de capital.

\subsubsection{Estática Comparativa}

A inclusão do Charter Value não solicita qualquer alteração nas equações do modelo básico, porque afeta apenas a condição de lucro de equilíbrio da indústria bancária. A estática comparativa conforme realizada no exercício do capítulo 2, seção 2.4.1, quando realizada para valores de Charter Value permitirão algumas conclusões gerais (ver figura 3.1):

1. A economia real não sofre qualquer alteração, uma vez que as variáveis reais estacionárias são descritas por parâmetros comportamentais que não dependem dos lucros da indústria bancária.

2. O Charter Value não altera os valores de longo prazo das taxas de juros finais de firmas e empreendedores porque esses preços estão atrelados a quantidades e preços da economia real;

3. Economias com lucros maiores apresentarão menor necessidade de capitalização interna para alcançar os níveis ótimos de capital.

A figura (3.1) contém a mesma organização de gráficos apresentada no capítulo 2, na seção que analisou as propriedades estáticas. A primeira coluna de gráficos contém relações associadas à eficiência do mercado bancário, a segunda coluna mostra índices de resiliência financeira e a terceira e última coluna variáveis que auxiliam a entender o comportamento macroeconômico. 
No eixo horizontal de cada gráfico está o domínio real que contém o intervalo analisado do parâmetro de política, no caso, valores possíveis de Charter Values. Cada ponto do gráfico é uma economia em estado estacionário exatamente igual em relação às outras, exceto pelo nível de Charter Value.

A análise gráfica da figura (3.1) revela que as economias são pouco diferentes para valores menores de Charter Value, mas apresentam comportamentos distintos e comparativamente proporcionais a partir de um certo nível da restrição técnica.

Até certo ponto, a imposição de barreiras à entrada não têm efeitos sobre a estrutura patrimonial de estado estacionário das economias, o que implicaria nenhum trade-off com a resiliência financeira no longo prazo. Nesses casos, a regulação dos lucros não amplia o estoque de capital ótimo e estacionário de longo prazo porque seu nível é determinado pela tecnologia bancária e tal alocação é superior aos lucros que são incorporados. Também a demanda de crédito e os depósitos bancários não são diferentes. Para esses casos, somente os lucros dos bancos serão diferentes e proporcionalmente maiores. Como os lucros maiores de economias com que impõem maiores barreiras à entrada são transferidos em boa monta para as famílias, proprietárias dos bancos, as transferências se equalizam com taxas finais de juros do crédito maiores, no contexto da restrição orçamentária das famílias, uma vez que a elasticidade-juros da demanda é zero. Portanto, para valores menores de Charter Value, a inclusão de barreiras à entrada somente aumenta o mark-up médio das firmas bancárias, indicando ineficiência alocativa.

Isso acontece porque existe o mecanismo de capitalização interna. $\mathrm{O}$ banco pode escolher de forma ótima o seu nível de capital bancário, obedecendo a regra de formação (2.38). Ainda que o regulador permita maiores Charter Values na indústria bancária, garantindo lucros maiores, os bancos apenas reacomodam o valor da capitalização necessária para alcançar o nível ótimo de capital, portanto mantendo a estrutura do passivo inalterada.

Todavia esse ajuste é possível até certo nível, a partir do qual os lucros incorporados serão suficientemente grandes tais que não exigirão qualquer capitalização interna. Tomando a regra 

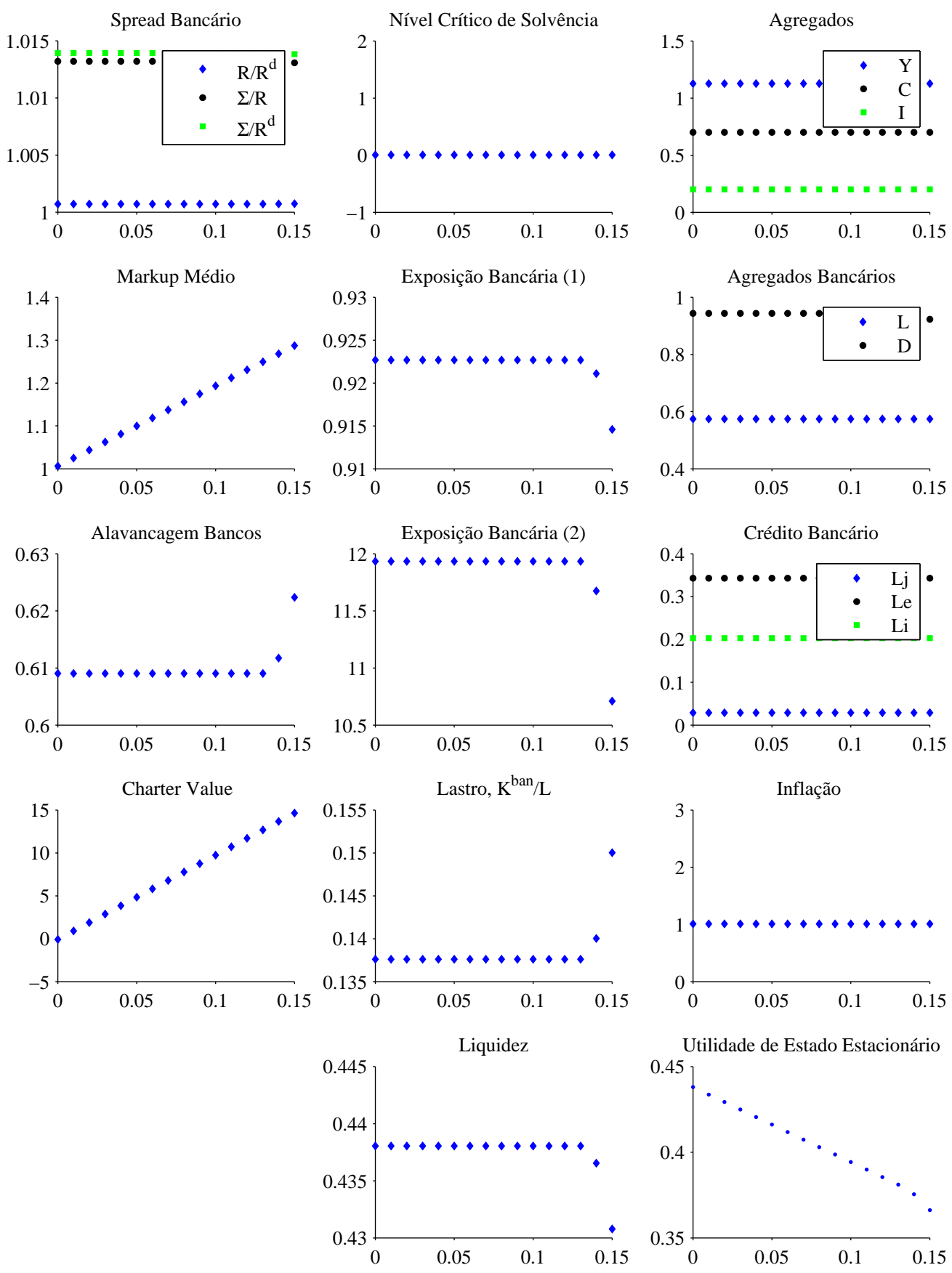

Figura 3.1: Estática comparativa de economias com valores diferentes de Charter Value bancário. 
de formação, os lucros de estado estacionário da indústria bancária, que determinam o threshold do Charter Value, medidos em termos de participação no produto são:

$$
\frac{\Pi^{\text {ban }}}{Y}=\frac{1}{\Theta} \frac{\Delta}{Y}
$$

em que $\Pi^{b a n} / Y$ é o nível de lucros da indústria bancária pelo produto da economia, $\Theta$ é a fração ${ }^{4}$ do lucro que é incorporada ao capital próprio, após tributação e distribuição de lucros e $\Delta$ é o nível de capitalização interna.

Nesse ponto, toda regulação de Charter Value altera o estoque de capital de estado estacionário e a estrutura do passivo do banco, com efeitos também sobre a dinâmica da economia. No modelo básico calibrado, esse threshold é calculado em 11.14\%. É a partir desse nível de regulação, conforme mostrou a figura e a análise, que o banco trabalhará com níveis superiores de capital bancário.

A regulação técnica imporá aos bancos mais capital de estado estacionário e o mecanismo interno de capitalização $\left(\Delta_{b, t} \geq 0\right)$ não permite corrigir o excesso de capital. Como as demandas por crédito são ancoradas nas decisões da economia real, que não se altera com a regulação, são menores os depósitos bancários nas economias com maiores barreiras à entrada. As taxas de juros dos depósitos bancários de equilíbrio são, portanto, suavemente maiores e o custo marginal do banco suavemente menores. O custo marginal operacional dos depósitos é decrescente na escala enquanto o ganho de escopo é menor (o segundo afeta o custo marginal e os juros sobre depósitos, enquanto o primeiro afeta apenas os juros sobre os depósitos e tem efeito superior aos ganhos de escopo). Os spreads suavemente menores são explicados pelo ajuste do passivo bancário.

A análise dos indicadores conceituais no estado estacionário evidencia que, pelo lado da eficiência microeconômica, o mark-up médio mostra substantivo crescimento, mesmo quando não há efeitos sobre o passivo bancário. Os volumes de crédito são iguais em todos os mercados e

$$
{ }^{4} \Theta_{t}=\left(1-\iota^{b a n}\right)\left(1-\tau_{t}^{\Pi^{b a n}}\right) .
$$


também as taxas de juros a empreendedores e firmas e é a taxa de juros do crédito às famílias que é maior, como consequência da transferência dos lucros maiores do banco no âmbito da restrição orçamentária da família. No longo prazo, a inclusão de maiores barreiras à entrada explica bancos mais alavancados. A interpretação mostra que, apesar de spreads suavemente menores e maior produtividade dos depósitos bancários, o Charter Value aumenta substancialmente o mark-up bancário, mesmo quando o mecanismo de capitalização interna é efetivo, porque o banco se apropria da renda que lhe é permitida pelo regulador técnico.

Os resultados estáticos concordam com as teorias e estimações que relacionam maiores Charter Values a maior resiliência financeira. Embora as motivações de equilíbrio parcial sejam específicas, aqui é a imposição de capital bancário superior, a partir do threshold, e a taxa marginal de substituição técnica que fazem cair os índices de exposição e aumentar as garantias sobre a administração do crédito e sobre a reposição aos depositantes. As economias apresentam menos liquidez porque a necessidade de moeda para pagamentos é menor e a substituição técnica entre depósitos e capital bancário explica bancos de menor tamanho em termos de ativos totais.

Sob a estabilidade macroeconômica, não são observados impactos relevantes de estado estacionário sobre os agregados macroeconômicos. A perda relativa dos serviços transacionais oferecidos aos depositantes explica economias com utilidades esperadas menores. Em síntese, a analise estática advoga que a intervenção sobre o Charter Value representa aumento do mark-up bancário e ainda menor eficiência econômica sob competição monopolística, o que é consistente em semântica com a direção pretendida pelo regulador técnico. Em contrapartida, o trade-off entre eficiência microeconômica e resiliência financeira se apresenta, mas apenas para valores acima do threshold, e está relacionado com uma nova estrutura de menor endividamento dos bancos e maior produtividade dos depósitos bancários.

\subsubsection{Dinâmica de Ajustamento}

A dinâmica de ajustamento é potencialmente afetada pela nova estrutura de passivo bancário que advém da regulação técnica. As funções de respostas ao impulso monetário estão na figura 
(3.2). São plotadas curvas de respostas para três economias com níveis distintos de regulação sobre as barreiras à entrada: a primeira supõe nenhum Charter Value, à semelhança do modelo básico; a segunda possui Charter Value tal que a relação lucro do banco e produto em estado estacionário é inferior ao threshold, portanto ainda com atuação do mecanismo de capitalização; por fim, a terceira economia opera com barreiras à entrada acima do limite que esgota as possibilidades de ajustamento e força o aumento do capital bancário.

Os choques de política monetária têm a mesma intensidade em todas as simulações, igual a um desvio-padrão, o que corresponde a 50 pontos-base, como no modelo básico. A dinâmica revela nenhuma interferência da regulação técnica sobre a economia real e seus agregados. Não há, portanto, trade-offs relacionados à estabilização do produto e consumo pela intervenção do Charter Value. Não há efeitos de inversão na dinâmica, apenas mudanças de intensidade e acomodação.

Os canais de crédito não são afetados. O acelerador financeiro e o canal de balance sheet do setor empresarial mantém a mesma depressão em timing, intensidade e persistência, independente da regulação. Os ajustes sobre as taxas de juros são mínimos, indicando também pouco ruído sobre o canal de juros bancários. O canal de bank lending é impactado pelo Charter Value porque a depressão dos depósitos bancários deve ser comparativamente maior quando o capital bancário aumenta, dada a taxa marginal de substituição técnica na tecnologia bancária.

O ajuste essencial está nos bancos. O choque contracionista de política monetária altera a substituição intertemporal entre lucros e estoque de capital. Todavia, nas economias mais capitalizadas pelo Charter Value, não se aplica mais o mecanismo de capitalização que permite corrigir a acumulação do estoque de capital bancário, portanto a transmissão do choque por esse canal de capitalização dos bancos deixa de ser efetivo. Nessas economias, o choque contracionista aumenta o mark-up médio do banco porque altera a participação dos mercados de crédito, em especial pela queda no crédito ao investidor. Apesar da escala inferior, o aumento dos lucros explica o capital bancário acima do valor de estado estacionário nas economias em que o Charter Value é suficientemente alto. Os efeitos dinâmicos, todavia, têm menor mag- 

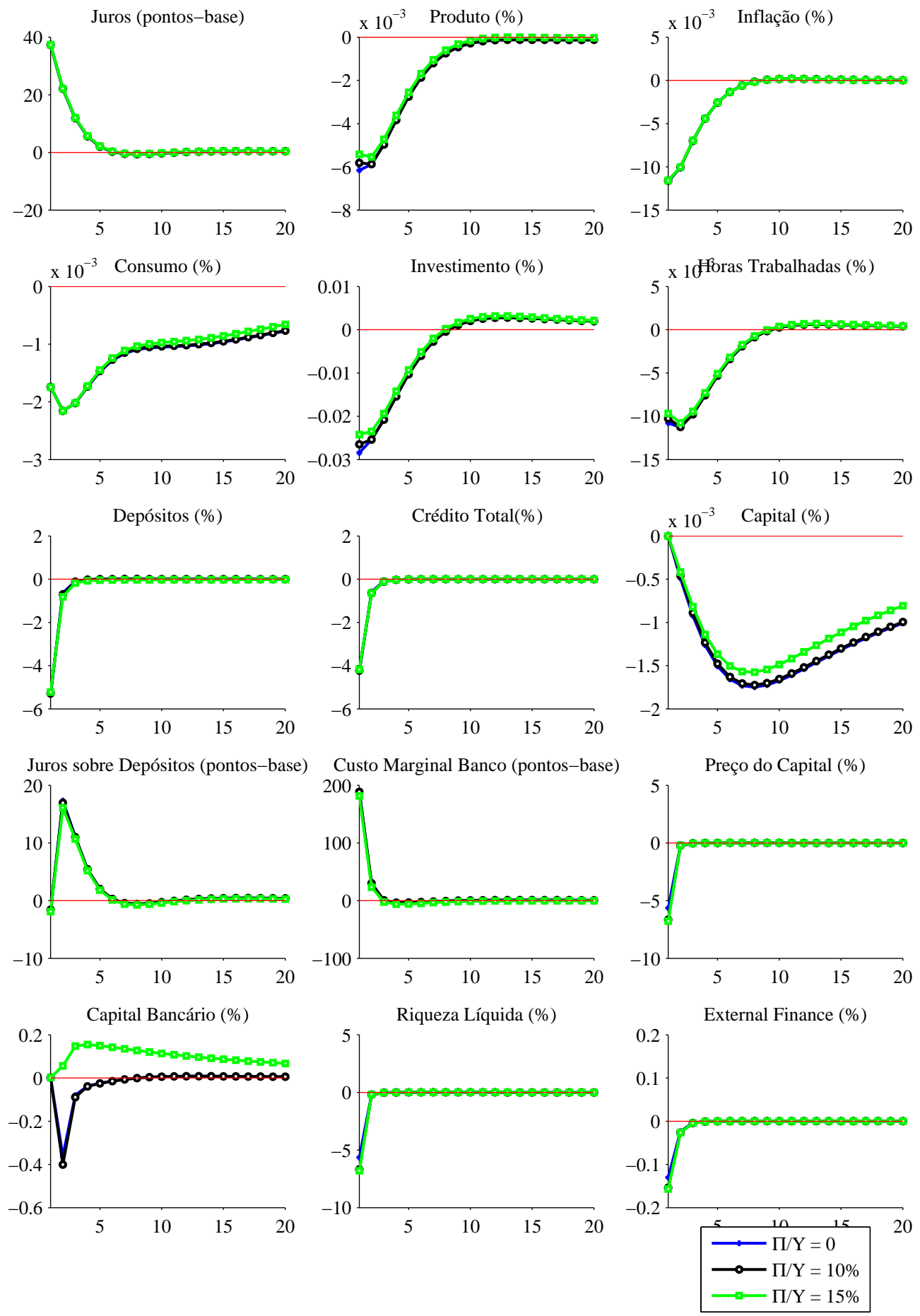

Figura 3.2: Respostas ótimas a choque contracionista de política monetária para economias com diferentes valores de Charter Value 
nitude, apresentam menos flutuação e menor persistência, justamente porque os bancos estão mais capitalizados no longo prazo e o ajustamento do capital próprio torna-se mais suave, o que se reflete em efeitos similares sobre os depósitos bancários.

A figura 3.3 complementa a análise apresentando os índices conceituais. Em geral, os agregados são pouco ou nada afetados pela intervenção técnica. As principais conclusões sob a perspectiva da estabilização macroeconômica são: i) a suavização do ajuste das medidas porque a volatilidade no capital bancário é menor quando as barreiras à entrada são maiores; ii) a persistência é fracamente alterada na direção de mais transição quando os lucros são maiores; e iii) os canais tradicionais de transmissão da economia real não perdem efetividade, muito embora os depósitos bancários, apenas eles, precisem de mais tempo para acomodar o choque monetário.

Os indicadores de resiliência mostram que o trade-off com a eficiência microeconômica se coloca não apenas em termos estáticos, mas também a dinâmica de ajustamento de economias com Charter Value maiores tem menos volatilidade e mais persistência, liderando a suavização dos efeitos do choque monetário sobre a estrutura de passivos bancários. A redução da liquidez é menor porque cai a demanda por moeda dos bancos para níveis menores de recursos de terceiros.

Bancos mais capitalizados não alteram o spread bancário de forma significativa, apesar de que a taxa de juros sobre depósitos tem elevação sutil acima da taxa de juros dos títulos públicos, também em face da menor demanda de depósitos bancários pelo banco. O efeito, ainda que mínimo, é pró-cíclico com o choque monetário.

A intervenção técnica do Charter Value é efetiva na produção do objetivo principal de alterar a eficiência microeconômica em direção a uma melhor proteção às firmas do mercado, quando a livre entrada e saída de firmas não é desejável. A regulação não revela trade-offs significativos entre a eficiência microeconômica e a estabilização macroeconômica em estado estacionário 

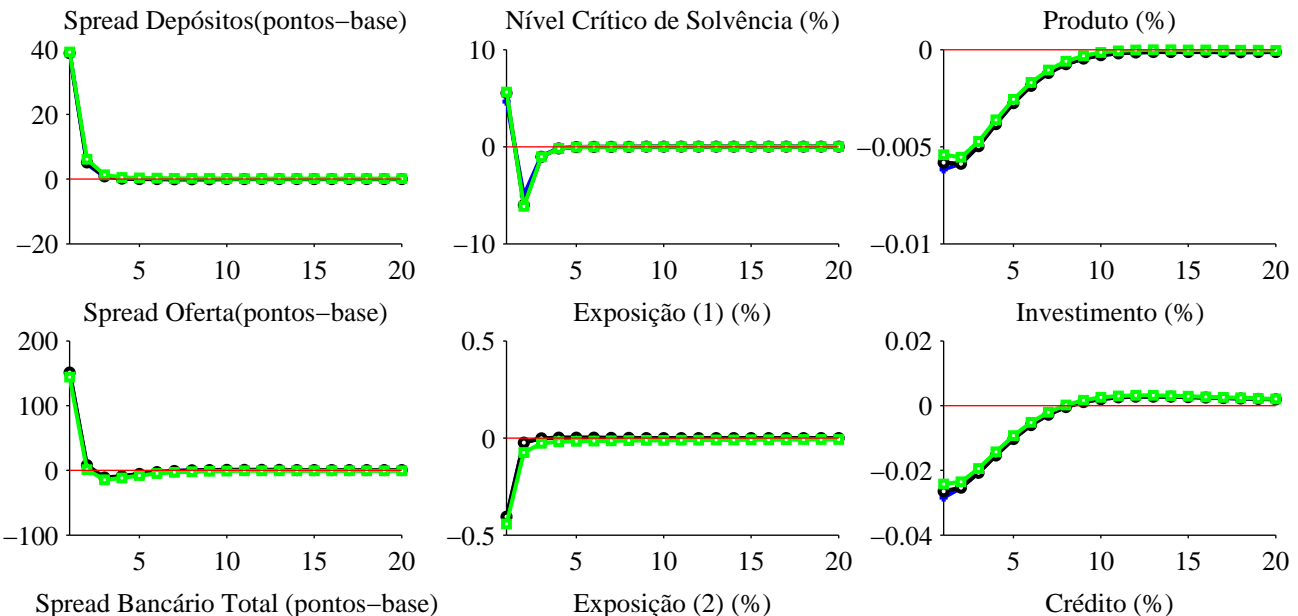

Spread Bancário Total (pontos-base)
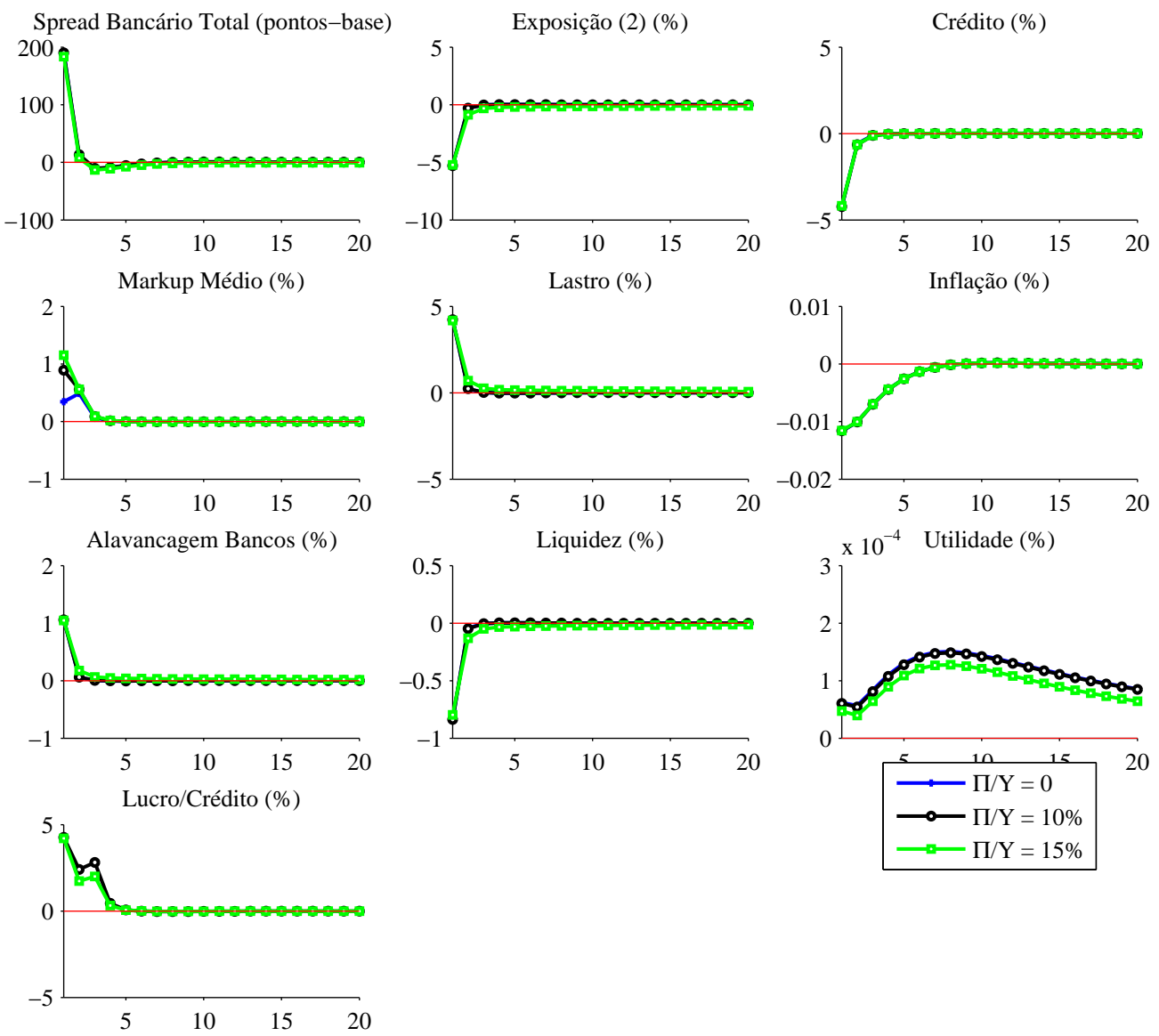

Figura 3.3: Respostas ótimas a choque contracionista de política monetária para economias com diferentes valores de Charter Value- indicadores conceituais 
ou na dinâmica de ajuste de política de juros.

Mesmo sem incorporar moral hazard ao problema do banco, ou incutir um problema de equilíbrio parcial para decisão de tomada de risco sob probabilidade de falência, como fazem normalmente os textos que analisam a constituição de Charter Value nos mercados, os resultados obtidos têm sintonia com a literatura. A inclusão de barreiras protege as firmas bancárias, evitando a entrada e saída de firmas, e obriga a maior capitalização dos bancos, induzindo a substituição de depósitos por capital bancário. O resultado é a melhoria geral em indicadores de resiliência financeira tanto em termos estáticos quanto na dinâmica de propagação da política monetária. Os artigos de Keeley (1990), Matutes \& Vives (2000) e Hellman, Murdock \& Stiglitz (2000) concordam que menores Charter Values bancários aumentam a competição e incentivam o comportamento tomador de risco das firmas bancárias.

Smith (1998) utilizou um modelo de equilíbrio geral para estudar custos macroeconômicos da competição imperfeita na indústria bancária. As falhas de competição são introduzidas por instrumentos de regulação cujo objetivo é dar estabilidade ao sistema bancário. A comparação em termos de performance macroeconômica indicou que aumentos de competição na indústria bancária geram mais renda e diminuem o tamanho dos ciclos. Os resultados obtidos por Alencar (2002) são opostos e mostram que a maior competição na indústria bancária gera mais flutuação no produto e que o canal de crédito balance sheet funciona melhor em economias mais competitivas porque as assimetrias de informação tornam-se mais sobressalentes. Fuerst (1995), por sua vez, encontra que imperfeições competitivas acrescentam pouco para a transmissão do choque monetário dentro da abordagem de ciclos reais. O autor trata especificamente dos custos de agência do contrato financeiro de investimento, mas ressalva que o resultado solicita mais pesquisa ${ }^{5}$ em torno de outros elementos que resgatem a correlação entre os choques monetários e a intermediação financeira.

\footnotetext{
${ }^{5}$ Carlstrom \& Fuerst (1997) retomam o assunto, mostrando que os custos de agência funcionam bem para explicar a autocorrelação do produto sob ciclos de negócios. Os autores argumentam que custos de agência e custos de ajustamento do capital têm a função de gerar as mesmas propriedades de oferta de capital.
} 
Os resultados não podem ser diretamente comparados com essa simulação porque o objeto de análise é diferente, embora guardem correlação. Aqui Charter Values menores sintetizam menores barreiras à entrada, maior contestabilidade e lucro econômico menor, mas os markups persistem e, portanto, a estrutura concorrencial é mantida sempre imperfeita. Sob choque contracionista, as barreiras aumentam o capital bancário e implicam em menor demanda por depósitos bancários para atender a demanda de crédito. Pouco é afetado o custo marginal do banco, apenas os mark-ups médios flutuam positivamente no curto prazo, indicando, portanto, que os bancos se apropriam das rendas geradas e as economias ficam temporariamente menos competitivas. Menores barreiras à entrada significam pouca alteração na dinâmica de transmissão monetária, mas notável mudança no passivo bancário.

\subsection{Recolhimentos Compulsórios de Reservas}

Os recolhimentos compulsórios são ferramentas tradicionais de execução de política monetária. A função principal é garantir liquidez do sistema bancário e reduzir a oferta de crédito à economia real. Como os depósitos são não remunerados, a exigência representa um custo ao banco equivalente à taxação de parte dos recursos captados por depósitos bancários. Ao imputar uma demanda por moeda ao banco, o objetivo do formulador de política monetária é alterar a reserva de liquidez e reduzir a oferta de crédito, com efeitos sobre as taxas de juros, dado o custo de oportunidade do instrumento.

Outra função dos depósitos compulsórios entendida modernamente como relevante é garantir a estabilização da demanda por reservas bancárias, uma vez que a demanda por moeda dos bancos pode estar motivada por fatores voláteis diversos, no caso do modelo básico, a liquidez para pagamentos. A rationale é que a volatilidade da demanda por moeda dos bancos acrescenta volatilidade também à taxa básica de juros, com problemas de sinalização indesejável de política monetária ${ }^{6}$.

\footnotetext{
${ }^{6}$ Canadá, Austrália, Nova Zelândia, México e Inglaterra são exemplos de países que não utilizam quaisquer recolhimentos compulsórios sobre depósitos.
} 


\section{Reservas compulsórias em moeda}

O modelo básico motiva a demanda por moeda dos bancos pela necessidade de liquidez para cumprir as obrigações de pagamentos em um sistema de liquidação bruta. A hipótese (2.4) assume que a necessidade é efetiva em qualquer período de tempo e a hipótese (2.5) garante que a liquidez é atendida por moeda e os remédios de liquidez atuam apenas em caso de surpresa na função pagamentos.

A função pagamentos indica qual a necessidade máxima transacional de liquidez para pagamentos intraperíodo, o chamado colchão de liquidez. A forma funcional assumida garante que a necessidade é crescente, mas sempre inferior ao volume de depósitos e é marginalmente decrescente na escala. $\mathrm{O}$ parâmetro estrutural $\eta_{\mathcal{P}}$ comanda a função, determinando que nível de liquidez pode ser característico a cada sistema financeiro nacional e suas particularidades de sistemas de pagamento. Obviamente fazendo $\eta_{\mathcal{P}}=0$ não há necessidade de colchão de liquidez, o que é o caso dos sistemas de pagamentos de liquidação diferida, sendo nula a demanda por moeda.

Políticas de reservas compulsórias sobre a moeda acrescentam a restrição (3.2) ao problema do banco A.6, p. 204. $\lambda_{4}$ é assumido o multiplicador de Lagrange correspondente.

$$
\left[\lambda_{4}\right] \quad \frac{M_{t}}{P_{t}} \geq \varrho_{M} D_{t}
$$

O problema ajustado do banco está no apêndice (C).

A restrição pode estar legalmente instituída mas não ser efetiva, quando o nível de liquidez exigido para pagamentos for superior à necessidade de pagamentos. Isso porque a moeda é mantida na conta de reservas da autoridade monetária e é permitido que os pagamentos inter- 
bancários liquidem nesta conta. Portanto, as restrições são mutuamente exclusivas.

$\varrho_{M} / \eta_{\mathcal{P}}$ é a razão entre os parâmetros de fração dos depósitos retidos em reservas de moeda e o parâmetro que escala o nível de liquidez requerido para pagamentos. A figura (3.4) estuda como a razão entre os parâmetros alterna a efetividade das restrições sobre o banco. Para um dado nível de depósitos, existe um threshold na razão $\varrho_{M} / \eta_{\mathcal{P}}$ para o qual valores abaixo da curva determinam que a liquidez de pagamentos é binding, enquanto valores acima da curva significam determinação da demanda de moeda pela política de depósitos compulsórios. A forma funcional da liquidez de sistema de pagamentos define o formato da curva: níveis mais elevados de depósitos solicitam mais reservas voluntárias em moeda, mas em proporção cada vez menor, porque o depósito marginal requer menos liquidez transacional.

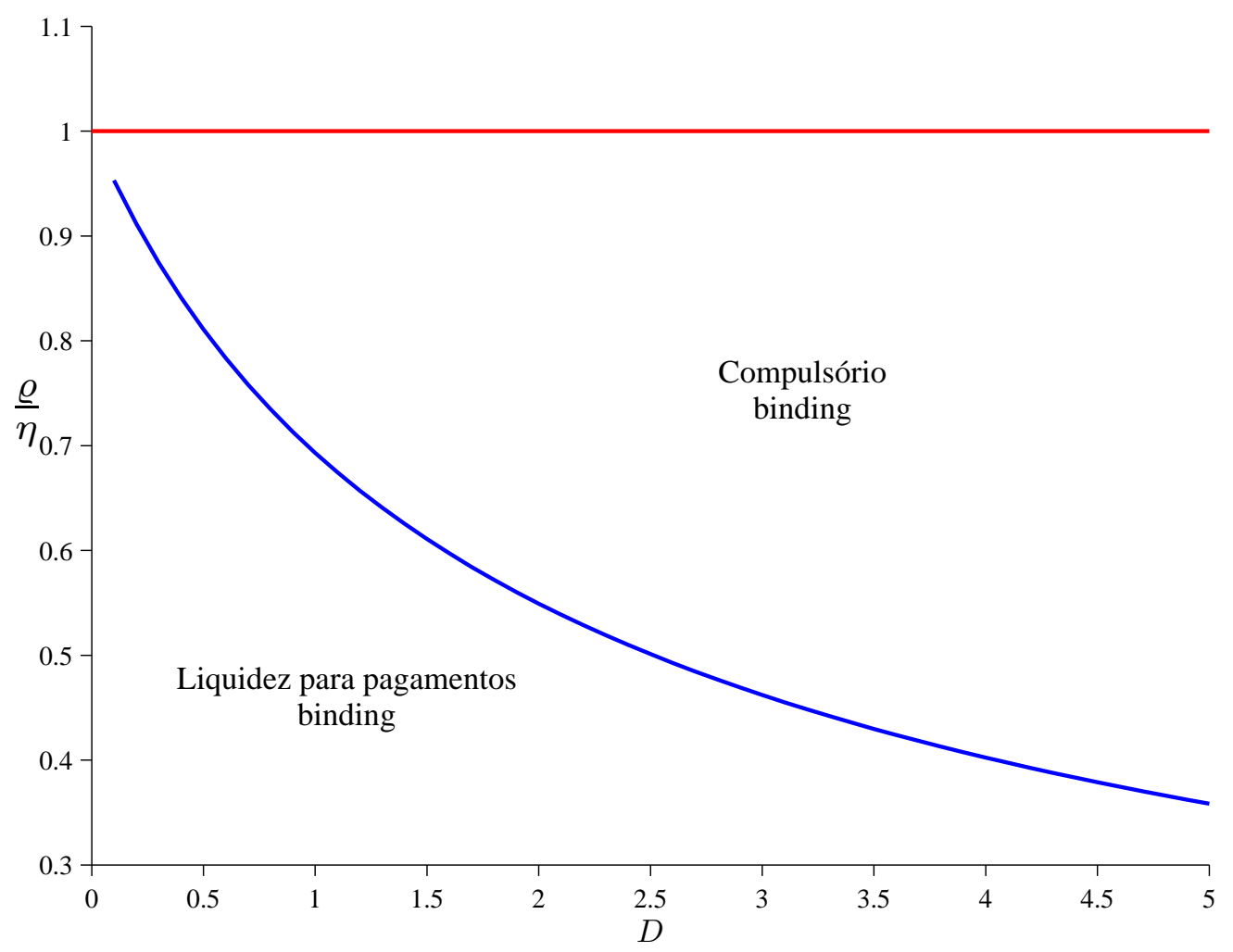

Figura 3.4: Determinação da demanda por moeda do banco sob política de reservas compulsórias

A análise do gráfico permite saber que existe uma única alíquota implícita que torna indiferente a motivação da demanda por moeda do banco. Assim, qualquer política de reservas compulsó- 
rias deve ter alíquota superior para ser efetiva.

Suponha que a autoridade monetária escolha um nível qualquer de compulsório em moeda superior à alíquota implícita. Portanto, para um dado nível de depósitos, isso implica que o volume de depósitos compulsórios dado pela equação de demanda do fator (2.53) não atende à restrição (3.2). A restrição de pagamentos não é mais efetiva e agora a equação de demanda de depósitos sob restrição de compulsório (3.3) é semelhante, à exceção do custo de oportunidade marginal do depósito bancário:

$$
R^{d}+\mathcal{C}_{d}+\underbrace{\left(R-E \frac{1}{\pi^{\prime}}\right) \varrho_{M}}_{\text {custo de oportunidade marginal }}=R+\frac{1}{\Lambda} \lambda_{2} z_{\mathcal{T}} \mathcal{T}_{d}
$$

O custo de oportunidade marginal do depósito bancário precifica quanto custa aumentar a demanda por depósitos em uma unidade considerando que parte deva constituir uma reserva não remunerada junto ao banqueiro central. Antes esse custo era decrescente na escala de depósitos, dada a função pagamentos em que $\mathcal{P}_{D D}<0$, mas, sob restrição efetiva de compulsórios, agora o custo é constante.

Para uma alíquota de compulsório acima da implícita, a demanda por depósitos bancários muda sua condição de ótimo, considerando a mudança no custo de oportunidade marginal. Na figura (3.5) estão plotados os gráficos de demanda por moeda e custo de oportunidade marginal no domínio dos depósitos bancários. A convexidade da função pagamentos implicará, dentro do domínio analisado, concavidade na função custo de oportunidade dos pagamentos. Observe que o nível de depósitos que torna indiferente a motivação da demanda por moeda não é o mesmo que torna indiferente o custo marginal. Assim, a alíquota implícita promove a inflexão da função demanda por moeda a um dado nível de depósitos, que é único, conforme a figura (3.4), porém, a esse mesmo nível, a função custo de oportunidade marginal apresenta diferença entre as funções.

Dessa forma, ao transitar para a demanda de moeda requerida para compulsório, o banco de- 
(A) Demanda por Moeda, $M^{\text {ban }}$

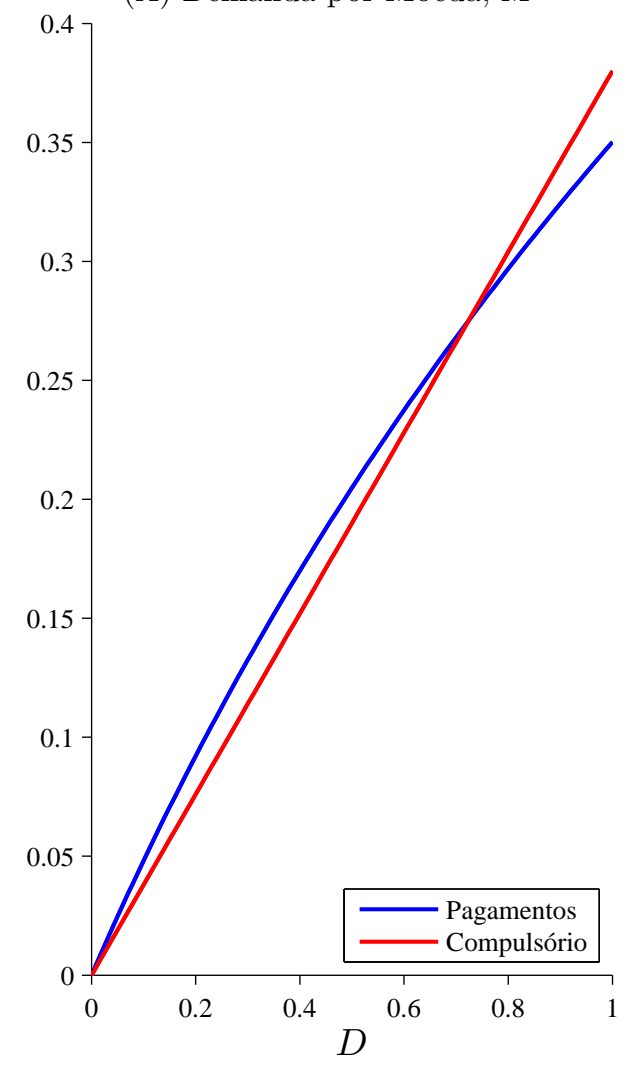

(B) Custo Marginal de Oportunidade

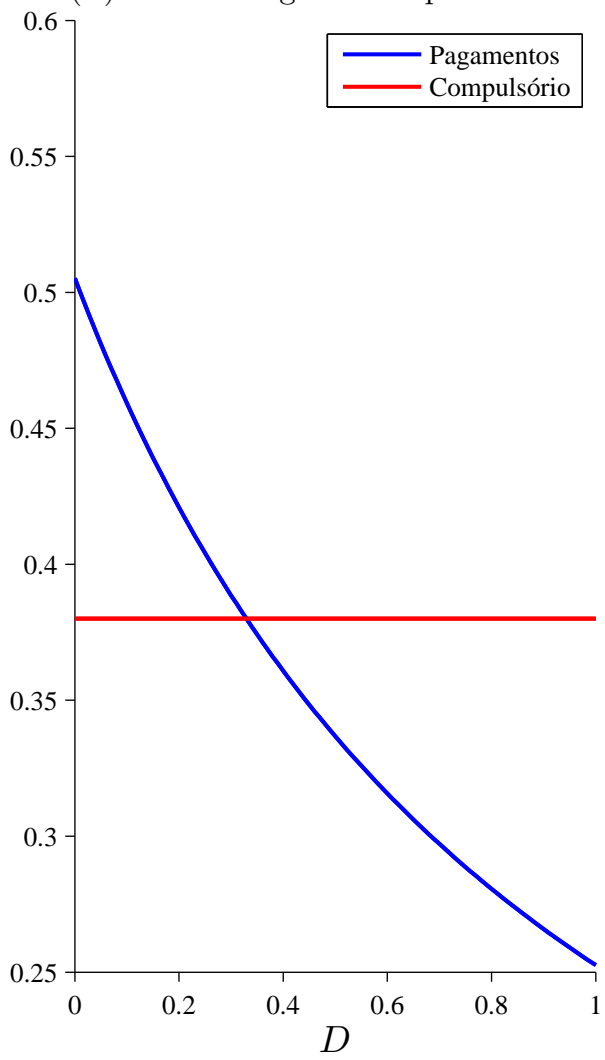

Figura 3.5: Determinação da demanda por depósitos bancários sob política de reservas compulsórias 
manda depósitos na equação em que $\lambda_{3}=0$ e $\lambda_{4}>0$, (3.3). O nível ótimo de depósitos todavia será menor. Mas a tal nível inferior de depósitos, a demanda por moeda não é motivada por recolhimentos compulsórios, mas por liquidez para pagamentos. Dessa forma, acima da alíquota implícita, existe um espaço de parâmetros no qual a demanda por depósitos bancários é indeterminada. Confira na figura (3.5).

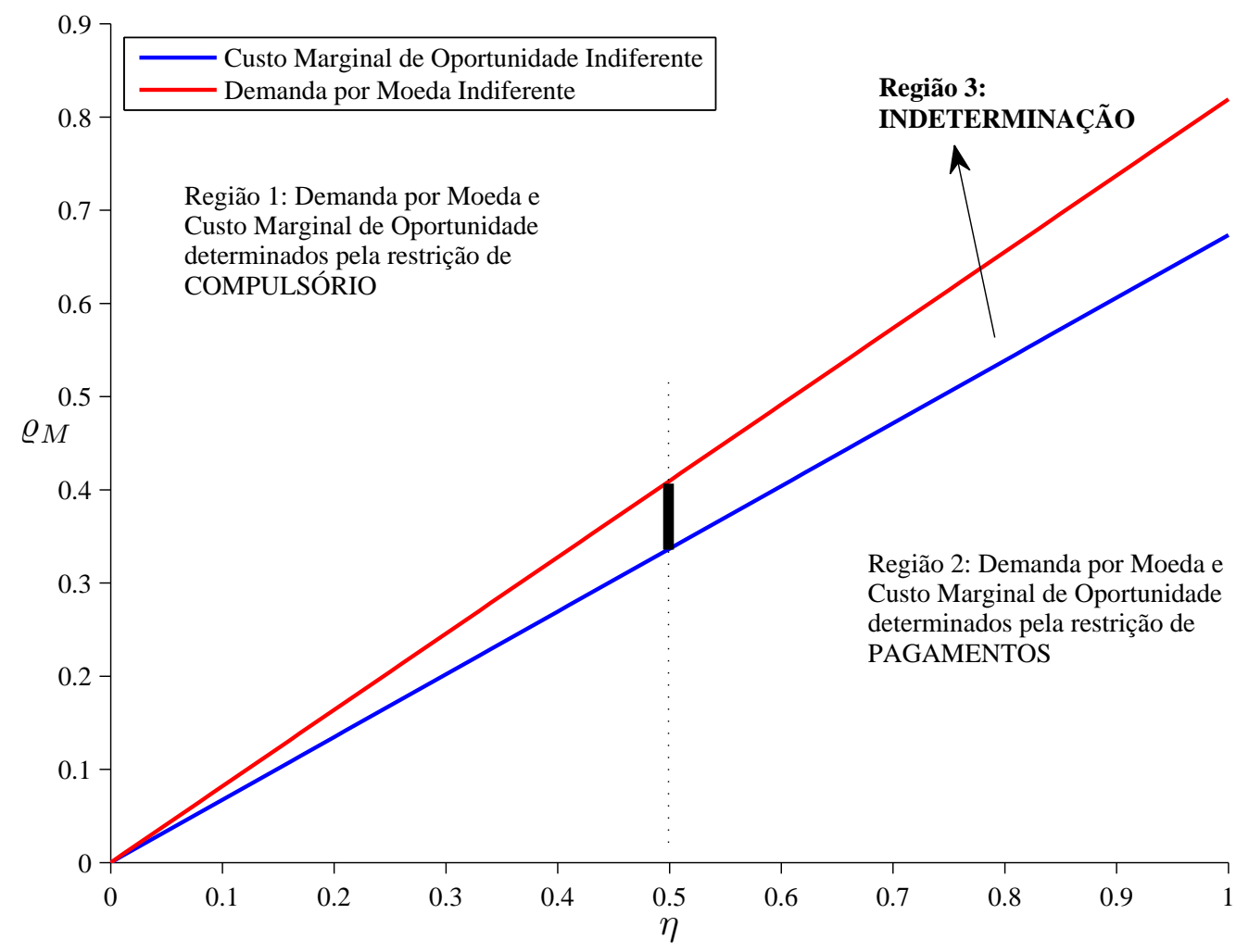

Figura 3.6: Espaço de parâmetros e determinação da demanda por depósitos bancários

Para um dado nível de depósitos bancários, analisa-se como os parâmetros $\left(\varrho_{M}, \eta_{\mathcal{P}}\right)$ das funções de demanda por moeda explicam a determinação da demanda por depósitos, como mostra a figura (3.6). A curva superior divide dois espaços de acordo com a demanda por moeda, acima da curva a demanda por moeda é determinada por compulsório em detrimento da liquidez para pagamentos. Por sua vez, a curva inferior define dois espaços de acordo com o custo de oportunidade de moeda. Acima da curva o custo de oportunidade dado por compulsórios é maior do que o custo quando a determinação vem da liquidez de pagamentos. Ficam portanto definidas três regiões para o espaço paramétrico. Pontos acima de ambas as curvas (Região 1), em que valores de $\varrho_{M}$ são relativamente maiores que $\eta_{\mathcal{P}}$, geram demanda por moeda motivada 
por recolhimentos compulsórios e demanda por depósitos consistente, ao passo que nos pontos abaixo das curvas (Região 2) a demanda por moeda vem da necessidade de liquidez para pagamentos.

Os pontos entre as curvas (Região 3) apresentam demanda por moeda determinada pela restrição de compulsórios para um dado nível de depósitos, mas a demanda ótima por depósitos bancários no custo de oportunidade do compulsório é atendida a um nível de depósitos menor, no qual a restrição de compulsório não é efetiva. O espaço entre as curvas gera um espaço paramétrico no qual a demanda por depósitos bancários é indeterminada.

Tome $\eta_{\mathcal{P}}$ qualquer. Duas alíquotas de compulsório definem a constituição de políticas de recolhimentos compulsórios $\left(\varrho_{M(1)}\right.$ e $\left.\varrho_{M(2)}>\varrho_{M(1)}\right)$. Para políticas com alíquotas inferiores a $\varrho_{M(1)}$, a restrição não será efetiva e a intervenção é inóqua. Para valores entre $\varrho_{M(1)}$ e $\varrho_{M(2)}$ não há equilíbrio porque o banco não consegue atender a demanda por moeda e coletar depósitos de forma ótima. Para valores superiores a $\varrho_{M(2)}$ a restrição de compulsórios é efetiva para determinar a moeda do banco, o nível de depósitos bancários é superior à necessidade de liquidez e a restrição (2.42), em valores esperados, não é efetiva.

A ponderação acima faz-se necessária porque há dois regimes determinantes da demanda por moeda atuantes no mesmo ambiente bancário. A prevalência em equilíbrio está relacionada às características comportamentais do ambiente (parâmetros e função pagamentos). A análise é sensível à forma funcional empregada, especificamente à convexidade imposta.

\section{Reservas compulsórias em títulos públicos}

A coexistência de políticas efetivas de reservas compulsórias em moeda e em títulos públicos tem impactos sobre a constituição do passivo bancário e sobre a oferta de crédito: este o objetivo principal da intervenção da autoridade monetária. 
A determinação do estoque de títulos públicos é endógena no modelo básico da seguinte forma: para uma dada estrutura de passivo bancário, a tecnologia define o nível máximo de crédito factível; os recursos desempregados são chamados de reserva de liquidez (2.1). Como a moeda é dominada em retorno, a ausência de fricções reais como liquidez para pagamentos ou mesmo políticas de compulsório sobre moeda implicaria saldos monetários nulos e a reserva de liquidez integralmente constituída por títulos públicos. Nesse contexto, para uma dada reservas de liquidez definida pela tecnologia bancária, a determinação de reservas compulsórias em moeda implica na pré-determinação do estoque de títulos públicos.

A imposição de política adicional de reservas compulsórias em títulos públicos colocam também a restrição (3.4) no problema do banco A.6. Agora $\lambda_{5}$ é o multiplicador de Lagrange.

$$
\left[\lambda_{5}\right] \quad B_{t} \geq \varrho_{B} D_{t}
$$

Proposição 3.1 A política de reservas compulsórias em títulos públicos será efetiva em equilíbrio estacionário se:

$$
\varrho_{B}>1-\frac{L-\mathcal{K}}{D}-\tilde{\varrho}_{M}
$$

A prova está no apêndice (C). $\varrho_{M}$ é a alíquota que representa a relação moeda depósitos independente da motivação da demanda. O lado direito é o nível endógeno de títulos públicos que o banco constitui de forma voluntária. A proposição garante que o compulsório de títulos públicos só é uma restrição binding se a alíquota for superior. A fração em (3.5) representa a reserva de liquidez endógena obtida no ótimo. Verifique que $L / D$ é a alavancagem bancária enquanto $\mathcal{K} / D$ é o inverso da medida da exposição bancária. A constituição de títulos públicos é sempre maior quando a alavancagem e exposição bancária são ambas menores. Claro, bancos relativamente mais capitalizados atendem a demanda por crédito com menos depósitos bancários, portanto, com menor necessidade de liquidez. A política de compulsório em títulos públicos fica potencialmente menos efetiva nesses casos. 
Se a restrição de compulsórios sobre títulos públicos é efetiva para um dado nível de depósitos, a reserva de liquidez é conhecida e a oferta de crédito é residual. Portanto, a efetividade da restrição de compulsórios sobre títulos implica na tecnologia bancária não efetiva, já que ambos definem a oferta de crédito.

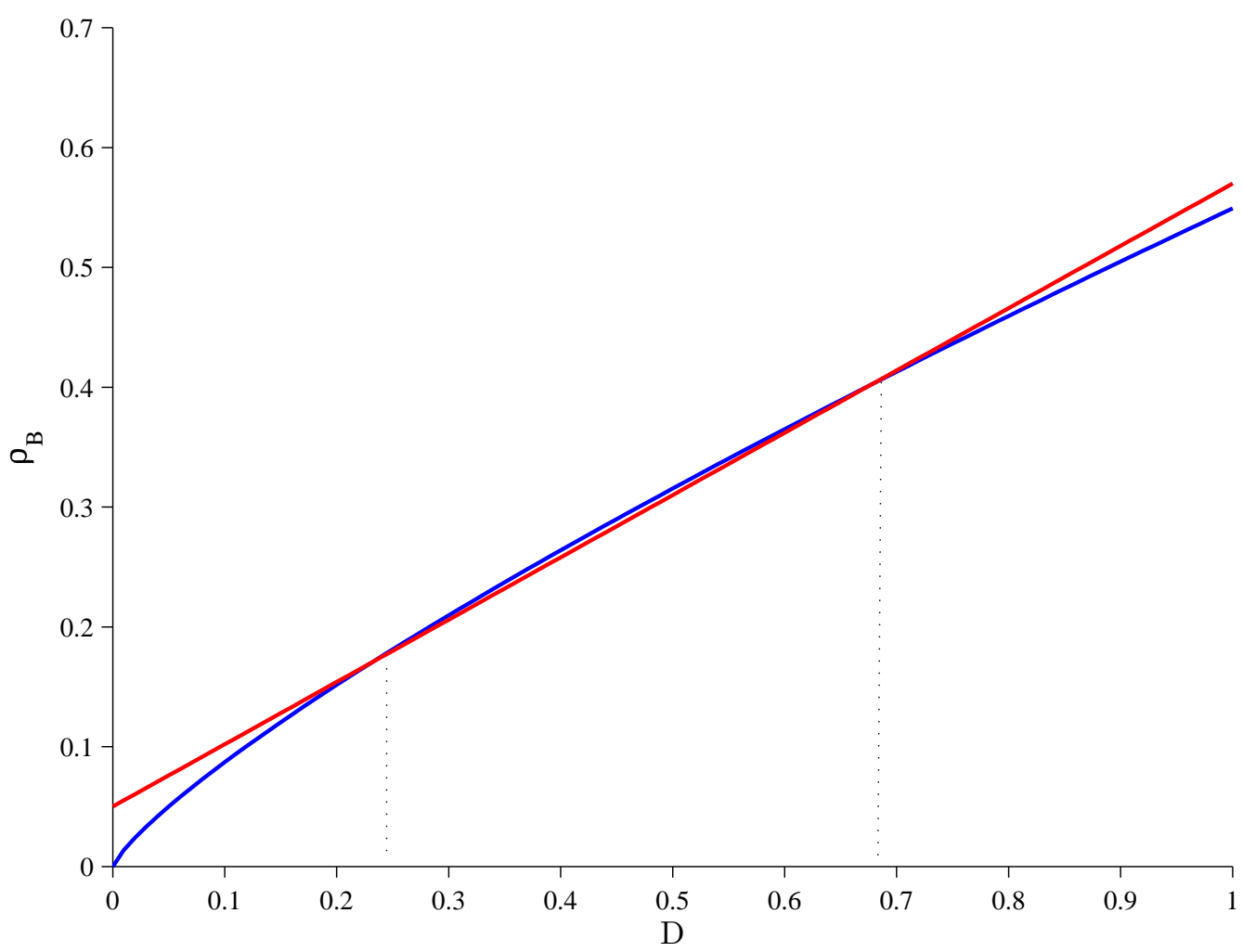

Figura 3.7: Determinação da oferta de crédito banco sob política de reservas compulsórias em títulos públicos

Observe na figura (3.7) a curva de fronteira tecnológica do banco no domínio dos depósitos, para um dado capital bancário. O nível de crédito deve estar abaixo da curva para atender (2.39). A reta é a determinação da reserva de liquidez quando existe uma política de compulsório em títulos públicos. Para valores razoavelvemente elevados ${ }^{7}$, a política de compulsório determina níveis de crédito abaixo da fronteira tecnológica, quando (2.39) não é binding.

\footnotetext{
${ }^{7}$ No Brasil, há oito tipos de recolhimentos compulsórios e encaixes obrigatórios: recursos à vista, recursos à prazo, recursos de poupança, recursos de depósitos e garantias realizadas, garantias de fiança bancária, adiantamentos de operações de câmbio, depósitos judiciais e recursos adicionais, conforme Circulares 3114 e 3157 . Apenas os recursos a prazo e os depósitos judiciais não são recolhidos em moeda, admitindo-se ganhos vinculados à taxa dos títulos públicos.
} 
O problema do banco estendido para a restrição de compulsório está na seção (C) do apêndice. Conforme reza a condição de ótimo, a restrição será efetiva se a taxa de juros dos títulos públicos for diferente da taxa de juros do ativo livre de risco em equilíbrio. Claro, nessa situação a posse de títulos públicos gera custos de oportunidade para o banco. Quando as taxas são iguais, a restrição nunca é binding. Para justificar o spread em equilíbrio, somente se o modelo representasse as condições de risco do título público, relacionadas às condições fiscais do governo. Portanto, para os exercícios seguintes de recolhimentos compulsórios, assume-se que a restrição para títulos públicos não é efetiva.

\subsubsection{Estática comparativa}

A figura (3.8) mostra os resultados do exercício de estática comparativa para variações no nível de exigência de recolhimentos compulsórios em moeda, que estão plotados no eixo horizontal de cada gráfico. A organização dos gráficos é a mesma dos exercícios anteriores correspondentes. Os demais parâmetros da economia seguem a calibração inicial, inclusive $\eta_{\mathcal{P}}=0.50$. A observação gráfica permite conferir inicialmente o espaço de parâmetros específico para o exercício, quando certas alíquotas de compulsório indeterminam o equilíbrio estacionário.

Os gráficos em que alguma diferença é percebida contém o mesmo padrão de mudança de nível e linearidade na proporção da alíquota compulsória. As mudanças são explicadas basicamente pela alteração no volume de depósitos bancários que as famílias emprestam aos bancos. Sendo a demanda por crédito a mesma em todas as economias, uma vez que não há variação no setor de bens, as alíquotas maiores significam proporcionalmente maior demanda de moeda pelos bancos e custo de oportunidade maior e proporcional à força da restrição. Isso deriva menor demanda de depósitos bancários. Com a demanda de crédito igual, será maior o capital bancário de equilíbrio nas economias sob requerimentos compulsórios e o aumento segue a medida de substituição técnica e a intensidade da regulação. Do ponto de vista macroeconômico, há somente queda na utilidade esperada, rapidamente explicada pela perda de serviços de transação associados aos depósitos. 

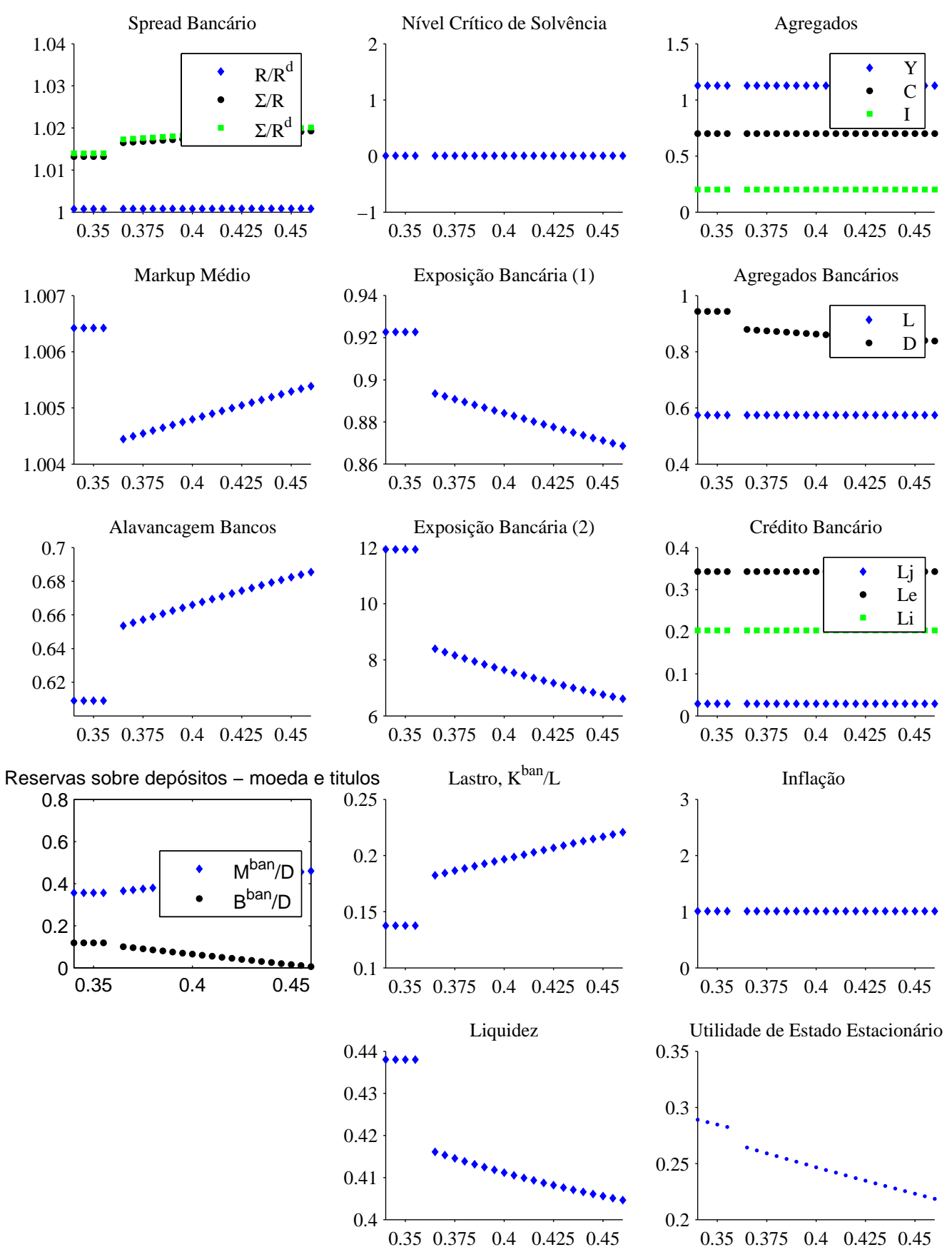

Figura 3.8: Estática comparativa de economias com valores diferentes de recolhimentos compulsórios em moeda 
Não há qualquer implicação ao lado empresarial e suas condições de crédito, então a qualidade do empréstimo não percebe mudança. As alterações no passivo bancário dão conta da redução dos depósitos e aumento do capital bancário. Economias serão mais capitalizadas porque alíquotas compulsórias maiores forçam a substituição de depósitos bancários por capital próprio. Nesse sentido, bancos ligeiramente menores e mais capitalizados são consequência da intervenção. A exposição bancária é menor e também a razão capital/crédito aumenta.

Apesar da aplicação de alíquotas compulsórias ter o propósito de garantir maior liquidez e reduzir a aplicação dos recursos de terceiros, no longo prazo o crédito é dado pela economia real. No longo prazo, a substituição de depósitos por capital bancário não evita a redução do passivo bancário. Relativamente, a reserva de liquidez fica menor nos sistemas mais controlados. A política de compulsório não aumenta a reserva de liquidez do sistema, porque apenas obriga a troca de títulos públicos por moeda, com custos para o banco. É por tal razão que economias mais afetadas por essa intervenção macroeconômica apresentarão índices de liquidez menores. Em termos de resiliência financeira, a intervenção de depósitos compulsórios aumenta a capitalização e reduz a liquidez no longo prazo.

Sendo efetiva, a restrição obriga o banco a substituir títulos públicos por moeda. Na ótica da eficiência, o aumento das alíquotas altera proporcionalmente os spreads bancários, mas a intervenção ativa determina margens ligeiramente maiores. O atendimento à restrição tecnológica fica mais caro porque o depósito marginal é parcialmente retido em reservas compulsórias. O preço de uma unidade de crédito é maior em nível e o custo marginal do banco fica também maior. Na captação a restrição efetiva implica aumento do custo de oportunidade, parcialmente compensado pelo aumento do retorno marginal do depósito, uma vez que o preço-sombra do crédito aumentou e a produtividade marginal do depósito é maior sob menor escala.

A intervenção determina aumentos proporcionais no mark-up médio. Isso acontece porque as economias têm a mesma razão de dívida e se os bancos possuem menos títulos com alíquotas maiores, as famílias têm maior participação nesse mercado. A renda maior dos títulos é contrabalançada, em estado estacionário, no escopo da restrição orçamentária, com o aumento 
dos juros finais do crédito para as famílias. Portanto, assim se explica mark-ups crescentes na alíquota. Em comparação à inexistência de reservas compulsórias, o mark-up médio é menor em nível porque o custo marginal maior não é repassável às taxas finais, que são determinadas pela economia real.

Faça-se uma observação geral a respeito do degrau que alguns conceitos apresentam quando muda a determinação da demanda por moeda. De fato, o que explica essencialmente a mudança de patamar é o degrau no volume ótimo de depósitos bancários. O nível é sempre menor quando o compulsório define o estoque monetário do banco porque o custo de oportunidade da moeda sob compulsório é sempre maior nos equilíbrios em que a intervenção é efetiva (conforme figura 3.5, gráfico B). O volume ótimo de depósitos menor na efetividade da intervenção sobre as reservas indica maior custo para atender a demanda de crédito, o que aumenta o preçosombra da restrição tecnológica em nível. Daí a replicação do evento nas demais variáveis.

\subsubsection{Dinâmica de Ajustamento}

O ajuste ao choque de política monetária é alterado em alguma medida porque a intervenção da autoridade monetária gera desvio na constituição natural do passivo bancário, obrigando o banco a tomar mais liquidez em moeda. Como já visto, a intervenção não tem a propriedade de alterar a reserva de liquidez dos bancos, que é definida endogenamente.

A figura (3.9) contém as respostas ótimas para três economias diferentes em termos de requerimentos compulsórios. Os demais parâmetros seguem a calibração base. A primeira economia tem requerimento de moeda em 30\% do volume de depósitos e essa restrição não é binding, porque a parametrização garante que o banco constitui livremente acima desse nível, exatamente $38 \%$, conforme consta da tabela (2.2). A segunda economia opera sob restrição efetiva de $40 \%$ de recolhimentos em moeda, enquanto a terceira economia atende a $50 \%$ em saldos monetários.

A dinâmica revela pouca interferência da intervenção sobre a liquidez do sistema bancário. 

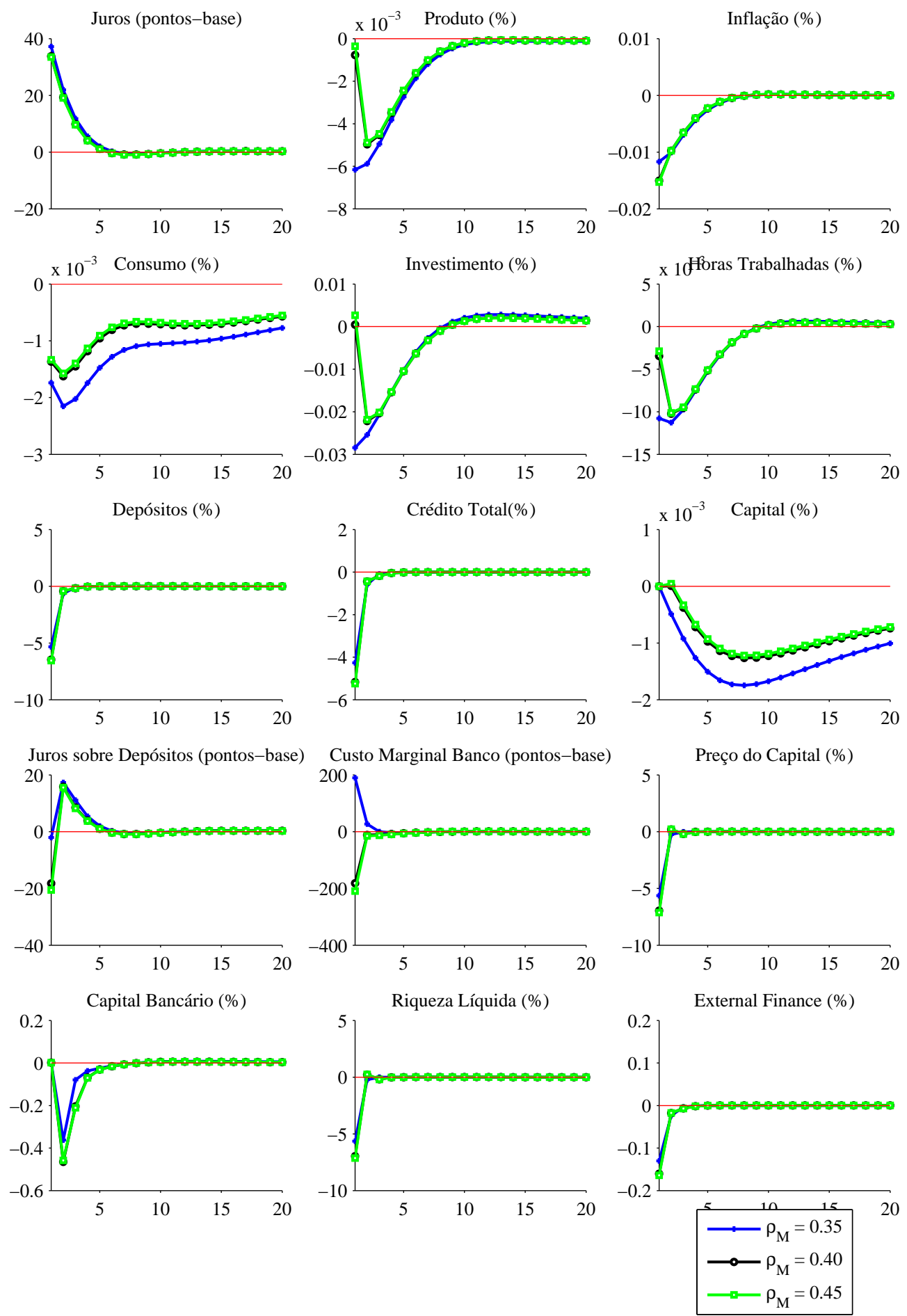

Figura 3.9: Respostas ótimas a choque contracionista de política monetária para economias com diferentes valores de recolhimentos compulsórios em moeda 
Produto, consumo e investimento são rapidamente afetados pela mudança nas alíquotas de compulsório. Também assim respondem o capital e o trabalho.

A explicação dos efeitos vem da tecnologia bancária. Sob maiores recolhimentos compulsórios, o choque de política monetária deprime a demanda de crédito e a oferta de depósitos da família. Os ganhos de produtividade tecnológica são decrescentes na escala, enquanto o custo de oportunidade é constante. No cenário de depósitos em queda, os ganhos marginais de produtividade são maiores enquanto o custo de oportunidade é constante ${ }^{8}$. Na ausência de intervenção, o nível de depósitos cai até equilibrar as perdas de oportunidade e os ganhos marginais de eficiência do fator. No caso da intervenção, as perdas de oportunidade são menores. A resposta ótima é a menor redução de depósitos e o ajuste pela substituição com o capital próprio, refletindo uma acomodação em que o capital varia proporcionalmente mais do que os depósitos. De fato, a intervenção impõe alguma rigidez na variação dos depósitos, mantendo os saldos acima do que seria a alocação livre.

Como os juros sobre depósitos aumentam na escala dos juros dos títulos públicos, indica-se que os ganhos tecnológicos são repassados para o preço $\lambda_{2}$ da demanda de crédito, no escopo da demanda do banco (3.3). A produtividade marginal dos depósitos revela que o custo de atender a restrição tecnológica é menor. Fica mais barato atender a demanda de crédito. É por tal razão que o custo marginal do banco reflete menos o choque monetário, liderando menor repasse às taxas de juros. A redução na oferta de crédito, portanto, é menor.

A intervenção reduz a propagação do choque pelos canais de crédito. O bank lending parece ser ainda efetivo, pois a redução dos recursos disponíveis para o banco reduz a oferta de crédito, mesmo com a atenuação que vem da substituição técnica.

Em essência, os efeitos dinâmicos mostram pouca flutuação adicional e mudanças insignificantes de persistência na comparação da potência da intervenção. O alinhamento do estoque de

\footnotetext{
${ }^{8}$ Repare que na prevalência da demanda por moeda pela condição de liquidez de pagamentos, a convexidade indicava maior retenção de moeda na margem, o que exigia maior redução de depósitos para que os ganhos tecnológicos equiparassem o aumento do custo de oportunidade.
} 
moeda ao compulsório não altera diretamente a reserva de liquidez, mas aumenta o custo de oportunidade de manter saldos monetários, com poucos desdobramentos sobre o custo marginal do banco. A política de recolhimentos compulsórios trabalha contra a efetividade dos canais de crédito. No sentido de ferramenta auxiliar de política monetária, sua atuação é indesejável.

Tome a figura 3.10 que finaliza a análise dos efeitos dinâmicos apresentando as relações conceituais. Os agregados são minimamente afetados pela regulação, mesmo os depósitos bancários. Do ponto de vista da estabilidade macroeconômica, a intervenção não gera trade-offs, mas a efetividade do canal de transmissão de política monetária é reduzida proporcionalmente no aumento das alíquotas. Também a variabilidade no nível de utilidade é maior sob compulsórios mais restritivos, representando a perda de serviços transacionais oferecidos pelos depósitos.

A política monetária determina maior variação para o capital bancário do que para os depósitos, pela substituição técnica. Os efeitos positivos de solidez do sistema financeiro gerados pela política monetária restritiva são menores pois os compulsórios reduzem a variabilidade dos depósitos bancários. A política também ameniza a queda de liquidez provocada pelo choque monetário. Lembre-se: a liquidez do sistema cai sob política monetária restritiva porque os efeitos sobre o passivo bancário são maiores do que os efeitos sobre o crédito. As reservas compulsórias atuam no sentido de aumentar a liquidez e reduzir a capitalização durante o ajustamento ao choque monetário. Os trade-offs são um efeito adjacente à proposta da intervenção.

A política monetária restritiva faz cair os spreads do banco e a política de compulsório amplia a redução, o que pode ser interpretado como ganhos de eficiência bancária. Apesar disso, os ganhos de alavancagem são razoavelmente menores com compulsórios mais intensivos, também resultante da impedância promovida na movimentação dos depósitos. No geral, a intervenção induziu ganhos de eficiência produtiva. 

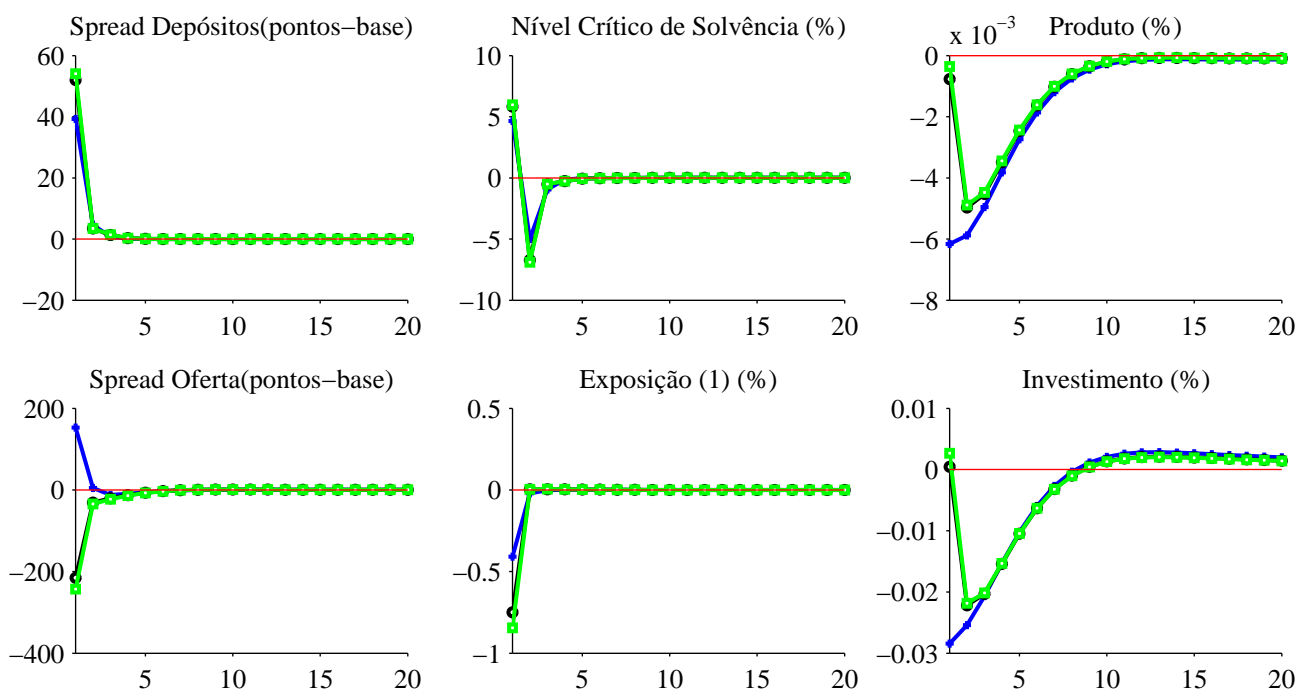

Spread Bancário Total (pontos-base)
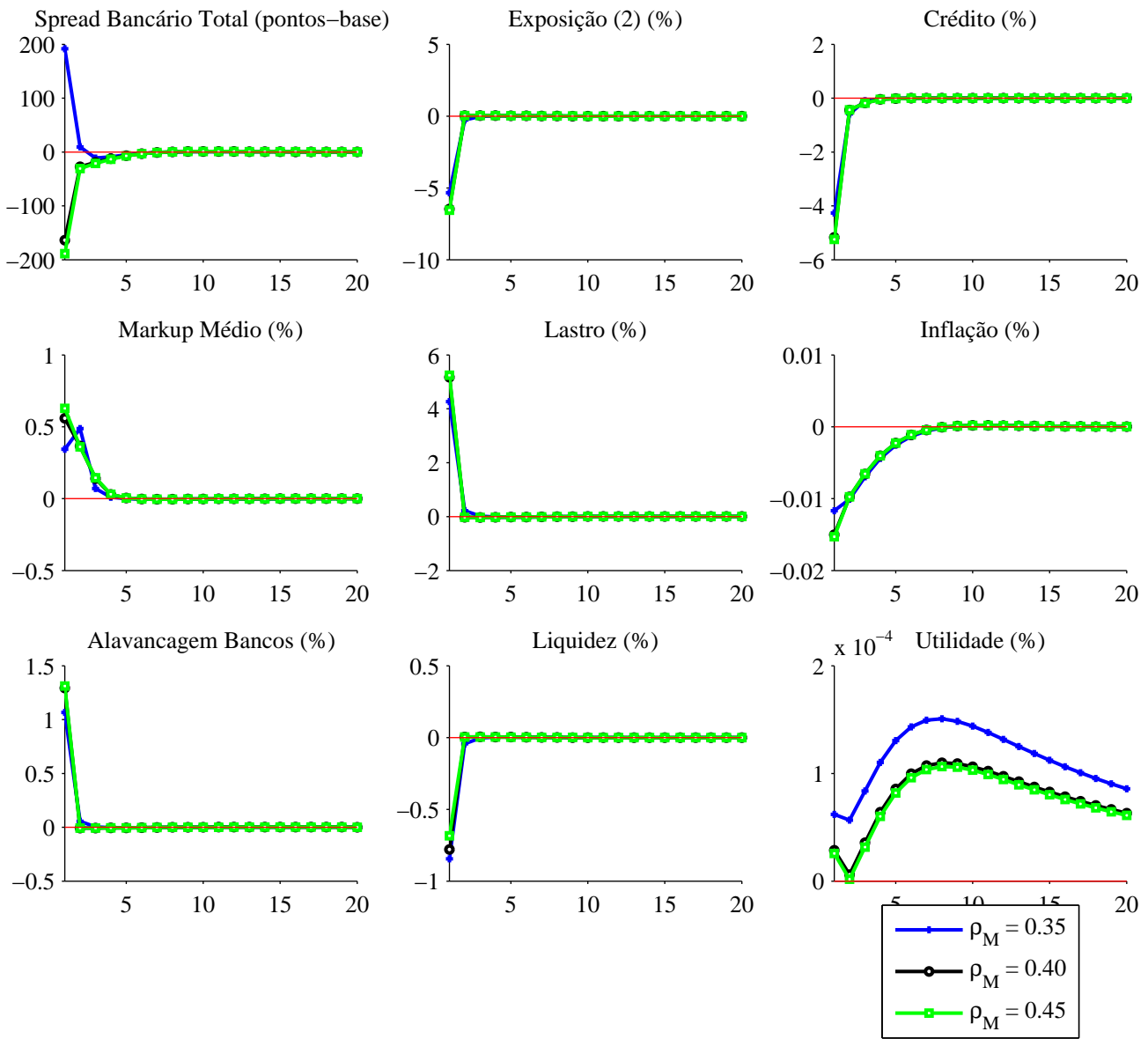

Figura 3.10: Respostas ótimas a choque contracionista de política monetária para economias com diferentes valores de recolhimentos compulsórios em moeda - indicadores conceituais 


\subsection{Requerimentos de Capital}

O objetivo primário da regulação de adequação do capital de bancos é limitar a tomada de risco pelos intermediários financeiros. A maioria dos países tem seguros sobre depósitos para proteção dos depositantes e para prevenir corridas bancárias. Todavia, bancos podem ter incentivos para tomar riscos, por considerarem o prêmio no caso de falhas. Os requerimentos de capital auxiliam a resolver o problema porque associam perdas nas operações de crédito ao capital próprio, dirimindo os ganhos no problema de maximização do banqueiro.

Os requerimentos também existem para determinar o nível de capital abaixo do qual o regulador intervém no banco para garantir o direito dos depositantes. Acionistas do banco pouco informados delegam ao regulador o direito de tirar o controle dos administradores, em um problema de moral hazard, como citado em Freixas \& Rochet (1997), Freixas \& Rochet (2008).

Os requerimentos de capital bancário podem afetar fortemente o comportamento do banco sob ciclos de negócios. Em ciclos de expansão econômica, o aumento do produto e do consumo é acompanhado por crescentes demandas de crédito, associadas à expansão da economia real, mas principalmente pelo aumento dos depósitos bancários. A expansão da renda que lidera maior oferta de depósitos bancários tem efeitos depressores sobre o capital bancário, segundo se observou na seção (2.4.2.2). Na ausência de outras fricções sobre o capital bancário, a tecnologia determina a acomodação da capitalização em períodos de abundância de recursos externos. Os bancos ficam mais endividados em ciclos positivos de negócios.

Impor requerimentos mínimos de capital gera vínculo entre o capital bancário e a tendência da demanda por crédito. Portanto, o ajustamento pelo capital bancário não se dá quando a restrição é efetiva, o capital do banco acompanha o crédito e as variáveis reais. Nesse sentido, requerimentos mínimos de capital são pró-cíclicos. Por óbvio, a demanda do banco por depósitos é relativamente inferior ao ambiente sem regulação prudencial, com efeitos sobre as taxas de juros. 
Em casos de depressão na atividade econômica, a redução da demanda por crédito e dos recursos de terceiros determinam qual será a acomodação do capital bancário. Na ausência de regulação prudencial, o impacto é não linear e comandado da tecnologia bancária. O aumento dos spreads explica o aumento do capital próprio, indicando que a razão de lastro aumentaria na vizinhança do estado estacionário. Mas na efetividade dos regulamentos de capital, a intervenção impõe um limite acima da livre alocação. Mesmo na depressão, a exigência de capital ainda será superior à livre alocação ${ }^{9}$. Os requerimentos de capital impõem base para o lastro dos bancos. A regulação prudencial, nesse contexto, também será efetiva e a sobrecapitalização ampliaria a redução da demanda por depósitos bancários e a redução do crédito. As conclusões do modelo não concordam nessa direção.

A pró-ciclicidade da regulação prudencial em fases de depressão econômica é uma argumentação recente, baseada na noção de que o aumento do risco que pondera os ativos de crédito na depressão implica em maiores requerimentos de capital. Esses modelos consideram o capital bancário apenas um custo para o banco e não ligam o processo de capitalização aos lucros nem aos ganhos de produtividade em uma tecnologia de oferta de crédito. Por outro lado, registrese que os riscos de ativos de crédito no modelo são descritos de maneira simplificada e não apresentam efeitos importantes para a análise de requerimentos de capital.

Suponha que o regulador prudencial presuma limites para o lastro do banco. O objetivo é produzir bancos relativamente mais capitalizados e resilientes a crises financeiras. Ao modelo básico, acrescenta-se a restrição (3.6). O problema do banco em (A.6), p. 204 é alterado nas condições de ótimo do crédito e do capital bancário. $\lambda_{6}$ é o multiplicador de Lagrange e $\Gamma \in[0,1]$ é o fator de exigência prudencial.

$$
\left[\lambda_{6}\right] \quad \mathcal{K}_{t} \geq \Gamma L_{t}
$$

\footnotetext{
${ }^{9}$ É preciso considerar que a economia sob requerimentos de capital tem a restrição efetiva e que os choques que a deslocam do estado estacionário são suficientemente pequenos de tal forma que, em nenhum momento, a restrição deixaria de ser efetiva, indicando que o capital bancário é mantido acima da alocação livre de regulação.
} 
O problema modificado consta do apêndice (C). A regulação implica na alteração na substituição intertemporal entre lucros e capital bancário, porque o valor marginal do lucro aumenta menos do que os ganhos intertemporais do capital bancário. Por isso, a capitalização interna é reduzida no ótimo, garantindo a equalização dos valores, conforme (C.10).

Também aqui a restrição pode estar legalmente instituída e não ser efetiva. Isso porque o capital bancário é um fator de produção que desempenha importante papel no gerenciamento de ativos do banco. Não é mero custo regulatório. Quando o estoque de capital bancário ótimo for superior às exigências prudenciais, a restrição é inativa.

\subsubsection{Estática Comparativa}

Requerimentos de capital, quando estabelecem uma restrição ativa, forçam o estoque de capital bancário acima da livre alocação do banco. A economia real não é afetada e a demanda de crédito é a mesma para todas as economias.

O equilíbrio estacionário sob maior rigidez prudencial se dá com ajuste no nível de depósitos bancários. Os bancos têm menor tamanho e são mais capitalizados. A alteração no passivo do banco tem as mesmas características de longo prazo da constituição de um Charter Value.

Os indicadores conceituais mostram que a capitalização obrigatória reduz a eficiência microeconômica. Apesar de a regulação implicar custo de constituir capital para conceder crédito, também reduz o custo de atender à restrição tecnológica. Os spreads não se movem por esse motivo. Porém mark-up médio aumenta porque os juros finais das famílias são maiores. A regulação gera lucros no longo prazo, aumenta as transferências e as taxas de juros finais no crédito às famílias. O trade-off se estabelece nos resultados porque a regulação gera economias mais resilientes em consequência de geração de algum Charter Value na indústria bancária. A taxa marginal de substituição técnica reduz os índices de exposição e aumenta as garantias para a administração bancária e o lastro aos depositantes. O índice de liquidez menor no longo prazo das economias sob regulação prudencial mais rígida decorre de menor necessidade de moeda 

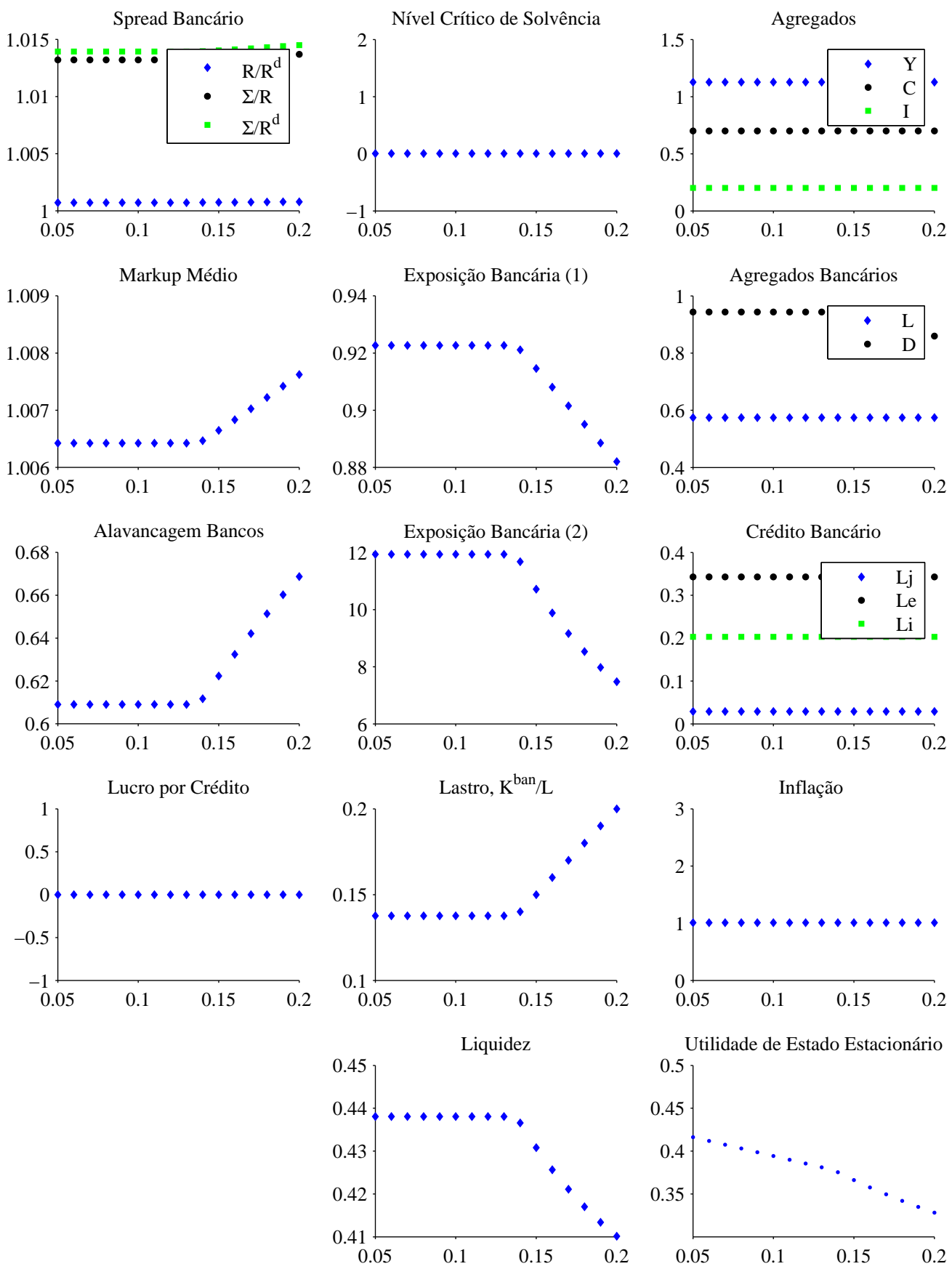

Figura 3.11: Estática comparativa de economias com alíquotas diferentes de requerimentos de capital bancário 
e de bancos de menor tamanho. Não há efeitos de longo prazo sobre a economia real. Apenas a perda relativa dos serviços transacionais oferecidos aos depositantes explica utilidades esperadas menores.

Resumindo a intervenção prudencial, a estática comparativa mostra trade-off entre eficiência microeconômica e resiliência financeira quando a regulação é efetiva. O objetivo prudencial têm êxito em reduzir os principais indicadores de garantia financeira do passivo bancário, liderando bancos menores e relativamente mais capitalizados.

\subsubsection{Dinâmica de Ajustamento}

A análise da figura (3.12) mostra como economias diferentemente reguladas se comportam na propagação do choque restritivo de política monetária. A primeira observação dá conta de que há mudança de comportamento quando a restrição é efetiva (casos de $15 \%$ e $20 \%$ de alíquotas), mas muito pouco se altera com a intensidade da regulação. Isso é explicável porque a restrição, em sendo efetiva, desvia bastante o capital bancário do seu estoque ótimo de equilíbrio não regulado.

A chave está realmente na análise do capital bancário. Os canais tradicionais de juros deprimem a economia real, e também os depósitos bancários e a demanda por crédito. O capital bancário atua de forma contracíclica, atenuando os efeitos contracionistas da política monetária, como visto no capítulo 2. Todavia, sob requerimentos prudenciais, o capital bancário acompanha a queda da oferta de crédito e cai proporcionalmente mais do que na economia em que os requerimentos não são efetivos, mas o capital continua acima da alocação livre.

O banco ainda sobrecapitalizado acomoda a queda da demanda de crédito quase que totalmente no capital próprio. A demanda por depósitos bancários reduz comparativamente menos, o que lidera menor pass-through da taxa de juros para a taxa do depósito bancário. Apesar do aumento das taxas de juros, o custo marginal do banco cai de forma vigorosa. Isso é reflexo das reduções dos custos tecnológicos e de regulação: primeiro porque o excesso de capital 
torna mais fácil atender à demanda de crédito, requerendo menos depósitos bancários; e, em segundo posto, porque a depressão torna o capital regulado mais próximo do seu nível livre de regulação, definindo queda no preço $\lambda_{6}$ de atender os requerimentos de capital. Principalmente a queda no preço da regulação é o que explica o custo marginal menor. Com taxas finais de crédito mais baixas, até insinua-se crescimento do investimento e do produto.

Em resumo, a regulação de capital inverte a acomodação do choque dos depósitos bancários para o capital próprio. A variabilidade da oferta de crédito é repassada ao capital e determina menor acomodação no lado dos depósitos. Isso é possível porque o capital é mantido acima do nível eficiente e tem custos para a sua constituição. Os canais de crédito são efetivos sim, mas em transmitir um sinal contrário ao da política monetária, liderando taxas mais baratas.

Os indicadores resumem de forma definitiva os impactos da regulação prudencial sobre a economia bancarizada. Ver a figura (3.13).

Sobre o ponto de vista da eficiência microeconômica, a intervenção prudencial não altera os spreads bancários no longo prazo, mas lidera significativa e não persistente redução dos spreads sob choques monetários. O mark-up médio diminui porque as taxas estão mais baratas e há aumento do crédito no mercado empresarial, o que aumenta a participação desse setor que possui a maior elasticidade-juros da economia. Apesar do trade-off de longo prazo, na dinâmica o que se apresenta é melhoria da eficiência bancária.

Ao melhorar a segurança financeira da economia no longo prazo, os requerimentos de capital reduzem a variação dos depósitos bancários. Isso define menos dinâmica nas condições de exposição bancária e na liquidez do sistema, o que é óbvio uma vez que a regulação atrelada à tecnologia bancária quase que fixa a reserva de liquidez dos bancos. O nível crítico de solvência ainda é menor em termos dos efeitos do choque, mas é comparativamente maior do que na ausência de regulação de capital. Isso porque, como visto, a queda das taxas de juros é suficiente para incentivar alguma tomada de crédito empresarial, mesmo em condições adversas no retorno do capital. 

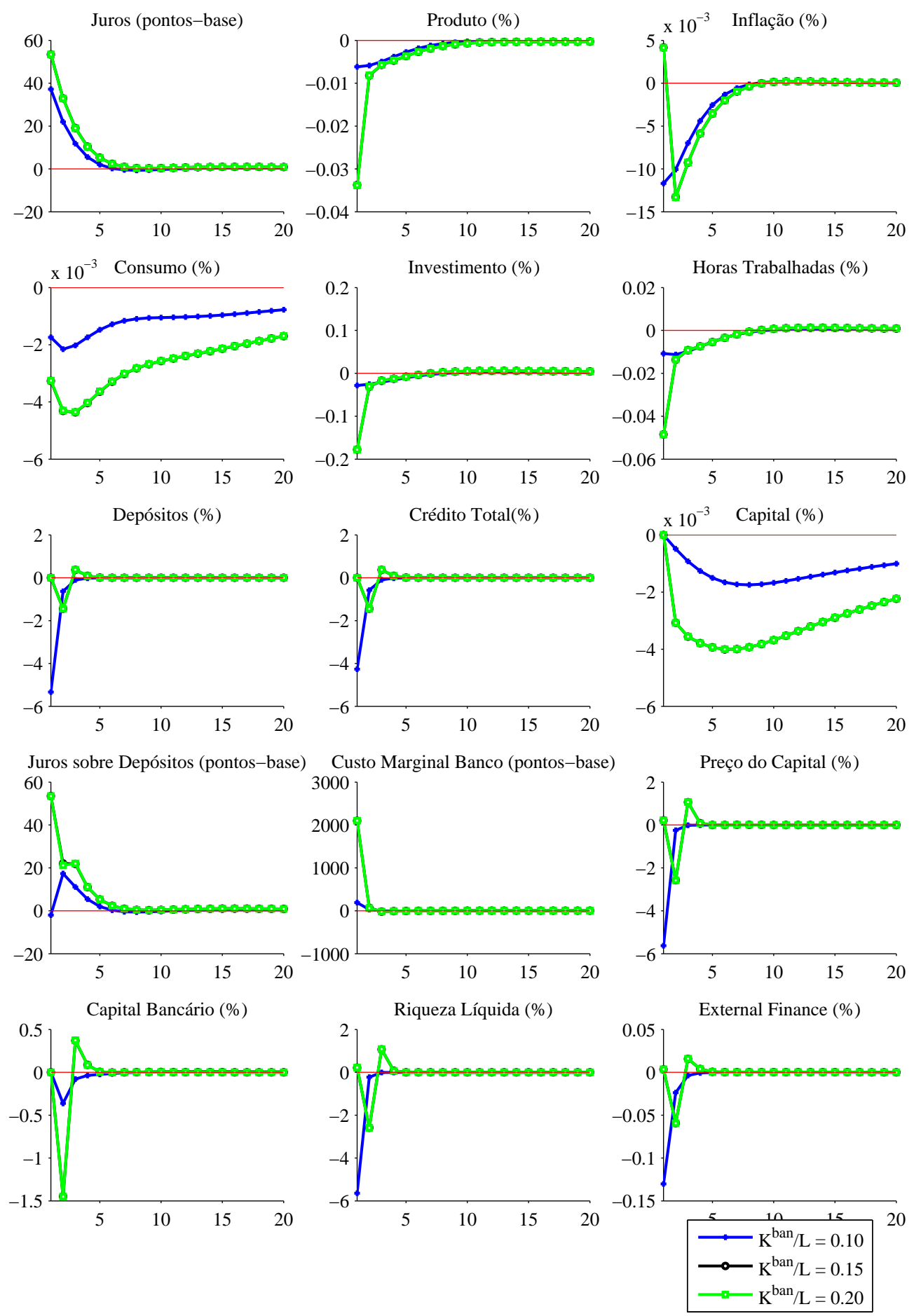

Figura 3.12: Respostas ótimas a choque contracionista de política monetária para economias com alíquotas diferentes de requerimento de capital bancário 

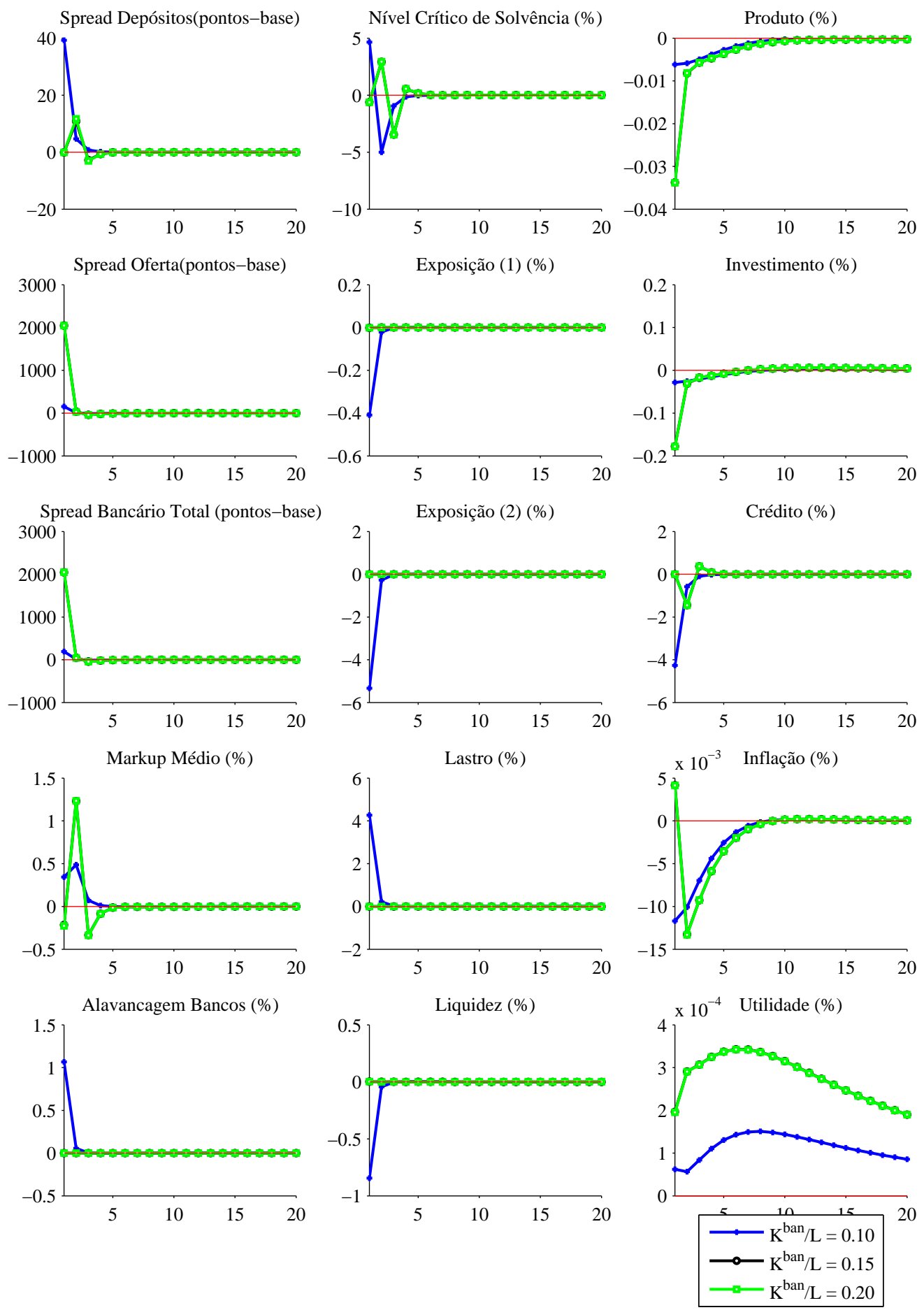

Figura 3.13: Respostas ótimas a choque contracionista de política monetária para economias com alíquotas diferentes de requerimento de capital bancário - indicadores conceituais 
As conclusões macroeconômicas são as mais interessantes. O modelo advoga que o passthrough dos canais de crédito é intensamente prejudicado sob regulação prudencial. A política monetária apresenta o efeito indesejado de desafogar as restrições prudenciais e encaminhar menores custos para o banco. Mas os inconvenientes não se reduzem ao mercado bancário. Com taxas finais de crédito mais baixas, há inversão dos efeitos sobre o investimento e o produto, causando tímida expansão sob política contracionista. Apesar disso, a inflação responde adequadamente ao instrumento monetário. Apesar dos efeitos corretos aplicados à economia real, o setor bancário e sua presença na economia reproduzem sinalização contrária ao afrouxar sua política de crédito. Nesse contexto, há trade-off entre a efetividade dos canais de crédito e a resiliência financeira promovida pela regulação prudencial sobre o capital bancário.

Atualmente, a noção de reforma da regulação prudencial recomendada aos sistemas financeiros passa por consertar a indesejável pró-ciclicidade dos requerimentos de capital. Novamente, se a pró-ciclicidade decorre da precificação dos ativos em situações de crise, o modelo atual ainda não é adequado para tratar as questões. Mas o modelo já responde que há necessidade de mais restrição monetária para impor efeitos reais na economia porque o canal de empréstimos bancários torna-se prejudicado com regulação prudencial de capital. Verifique que não é a intensidade da regulação, mas sua existência, o que implica refração nos canais bancários. Sob esse ponto de vista, medidas contracíclicas de requerimentos de capital podem ter sucesso relativo na recuperação da efetividade dos canais de crédito.

Alguns trabalhos concordam que a eficácia do mecanismo de transmissão monetária depende de como os bancos estão capitalizados. Kashyap \& Stein (1994) mostraram, em um modelo estático e simples, que, quando os requerimentos de capital são efetivos, os empréstimos bancários podem não responder à política monetária. A capacidade de o banqueiro central atingir o produto real mediante o instrumento de juros fica comprometida. Em um outro modelo também estático, Tanaka (2002) pondera que o mecanismo de transmissão monetária é enfraquecido se os bancos estão pouco capitalizados ou se a regulação prudencial é muito rigorosa. Isso porque, sob tais condições extremas, existe pouco escopo para expandir a oferta de moeda em resposta à política monetária. Para a autora, a pouca eficácia do instrumento monetário em ambien- 
tes de fortes exigências de capitalização bancária pode ser interpretada como característica de pró-ciclicidade dos requerimentos de capital, uma vez que solicita mais esforço monetário para conduzir efeitos reais na economia.

Apesar dos trabalhos citados e da grande evidência empírica encontrada nesse sentido, a literatura teórica não tem contribuído com modelos mais completos para tratar esses fatos econômicos. Santos (2000), após detida análise da literatura especializada, conclui que não há consenso no desenho de políticas ótimas prudenciais porque a natureza das falhas que justificam a intervenção não estão suficientemente descritas. As conclusões não suscitam convergência em modelagem ou políticas. O autor aponta que existem outras questões relacionadas que ainda não foram respondidas, como o desconhecimento das condições ajustadas de eficiência das instituições financeiras e o comportamento de risco dos bancos.

A falta de teorização deve-se possivelmente a dois motivos: i) a aceitação restrita de que exista um canal de empréstimos bancários relevante para a propagação de política monetária, donde regulações quaisquer sobre agregados do passivo bancário devam ter ainda menos relevância; e ii) a pouca importância que se dá aos impactos estáticos e dinâmicos da regulação prudencial quando comparados aos benefícios presumidos de sistemas financeiros razoavelmente capitalizados e, portanto, aparentemente mais seguros contra instabilidades financeiras.

Este capítulo implementou análises de estado estacionário e de dinâmicas de acomodação do choque de política monetária para três intervenções do Estado sobre o mercado bancário. A primeira é uma intervenção que emerge da regulação técnica, a necessidade de instituir certo nível de recursos para a entrada é exigência para a inclusão de firmas melhores no setor. $\mathrm{O}$ Charter Value representa requisitos mínimos entendidos pelo regulador como suficientes para escolher a qualidade das firmas entrantes.

Os resultados obtidos pela avaliação da regulação técnica dão conta que a inclusão de Charter Values efetivamente significa perda de eficiência bancária no curto prazo e no estado estacio- 
nário. Em termos estáticos, as barreiras à entrada aumentam o mark-up médio do setor, porque os ganhos de eficiência não são repassáveis aos tomadores de crédito, uma vez que os juros em cada setor são determinados pelas relações da economia real. Há sobrecapitalização quando os valores de Charter Value ultrapassam o valor de capital de estado estacionário. O excesso de capital melhora os indicadores de resiliência financeira no balanço do banco. Já a dinâmica de ajustamento é parcialmente alterada: embora nenhum efeito adicional relevante seja percebido nos canais de transmissão monetária e na efetividade da regra de juros, economias com maiores barreiras a entrada apresentam flutuação diferenciada no mark-up médio. Antes havia ganhos de eficiência repassados aos tomadores de crédito, agora os ganhos de eficiência do ajustamento implicam em margens maiores para o banco. A política monetária, normalmente alterava as fontes de recursos bancários, agora gera efeitos ampliados porque o capital bancário apresenta ainda maior impedância. As flutuações nos indicadores de resiliência financeira são favoráveis à segurança sistêmica. Portanto, o trade-off entre eficiência bancária e resiliência financeira define-se em termos estáticos e dinâmicos.

A segunda intervenção vem dos manuais da Macroeconomia, que se referem aos requerimentos compulsórios sobre depósitos como instrumento de controle da liquidez do sistema e, portanto, de controle da oferta de crédito. A atuação moderna reflete apenas um instrumento auxiliar de política monetária, enquanto vários países sequer têm a regulamentação instalada em seus sistemas financeiros. Nos dias atuais, não faz sentido entendê-la como uma restrição efetiva para o problema do banco nos países em que o sistema de pagamentos exige colchões de liquidez razoavelmente superiores, embora sirva ao exercício da tese. Os requerimentos compulsórios de recursos alteram o comportamento do banco no longo prazo. Os depósitos bancários, mais caros, são reduzidos enquanto fator de produção. Os bancos ficam menores em tamanho e a relação capital próprio e recursos de terceiros indica menores índices de exposição. Bancos relativamente mais capitalizados e custos de oportunidade maiores explicam spreads maiores. Mas no longo prazo, o banco não consegue repassar as taxas e o mark-up médio é menor. Ainda assim, associa-se a tendência de perda de eficiência de spreads operacionais maiores com ganhos de competitividade na indústria no longo prazo. 
O choque monetário causa maior ajuste nos depósitos bancários em economias reguladas mais fortemente com requerimentos compulsórios. Isso porque os depósitos bancários se tornam mais custosos na margem. Todavia o capital bancário também responde ao choque monetário com queda, agora amplificada pela substituição técnica. O efeito predominante são os ganhos tecnológicos, que indicam custo marginal bancário ainda menor. Assim o repasse às taxas finais fica mais prejudicado, atentando contra a efetividade dos canais de crédito. A depressão dos fatores de produção portanto gera ganhos tecnológicos que lideram ganhos em eficiência bancária, com spreads menores e mark-up médio menor, este explicado pela reacomodação nas participações dos mercados de crédito. Os índices avaliam redução na exposição bancária, indicando que o movimento do capital bancário foi no sentido da substituição técnica. O lastro das operações de crédito fica sutilmente menor porque a acomodação dos fatores evita a retração maior da oferta de crédito. A liquidez do sistema cai timidamente em virtude da redução comparativa da reserva de liquidez. Em síntese, a substituição depósito e capital próprio em termos da tecnologia bancária de produção não evita as perdas de escala, a oferta de crédito ainda cai sob choque de moeda. Todavia cai menos, indicando menos importância do canal de empréstimos bancários bank lending na transmissão de políticas monetárias.

Por sua vez, os requerimentos de capital são a intervenção do Estado sobre os bancos mais referida nos dias atuais. A restrição vem da necessidade internacional de monitorar o passivo bancário com o objetivo de evitar a produção ou a propagação de crises pelo setor bancário, com externalidades de rede atualmente além das fronteiras domésticas. O objetivo direto é controlar a qualidade da administração dos ativos dos bancos pela observação de indicadores de garantias da estrutura patrimonial.

Na economia estacionária, a intervenção é cumpridora de objetivos. Porque atrela o nível de capital ao nível de crédito, a restrição quando efetiva implica em capitalização acima da eficiente e promove a retração dos depósitos bancários enquanto fator de produção. Daí se explica a queda na exposição do banco e estruturação da indústria em bancos menores e mais capitalizados. A liquidez do sistema é alterada porque a reserva de liquidez é endógena, a redução nos depósitos é proporcionalmente maior do que a retração no crédito e no capital. 
Spreads iguais indicam que os ganhos tecnológicos foram compensados pelo custo de manter capital bancário acima da alocação ótima sem restrição. A intervenção reduziu a fragilidade financeira sem grandes custos em termos de eficiência.

As maiores conclusões sobre a intervenção de recolhimentos compulsórios estão relacionadas à dinâmica de ajustamento. Como o capital bancário é direcionado para acompanhar o movimento do crédito, isso implica em estoques sempre acima da alocação livre, até porque a restrição é efetiva. O excesso de capital indica menor queda dos depósitos bancários e ganhos tecnológicos reduzem o custo marginal de maneira vigorosa, isso porque o banco consegue atender a demanda de crédito de maneira mais fácil porque está sobrecapitalizado, a retração nos depósitos não parece apresentar dificuldades para a captação. O choque monetário todavia reduz o custo de manter o estoque de capital em níveis tão elevados, a retração do crédito traz o capital para níveis mais próximos da alocação livre de regulação, e por isso a economia observa ganhos de eficiência. A redução do custo marginal do banco prejudica bastante o pass-through da política monetária pelos canais de crédito bancário. Em termos dinâmicos, há estabilidade nas condições de resiliência e mais eficiência produtiva, embora o mark-up médio maior indique que parte das rendas são retidas pelos bancos. A regulação prudencial torna potencialmente não efetivos os canais de crédito para a transmissão monetária e, na hipótese de que eles são relevantes para os efeitos reais de política de juros, indicam perdas em termos de estabilidade macroeconômica. Relembre-se que tais resultados concordam com a hipótese de pró-ciclicidade da regulação na medida em que solicita mais esforço monetário para cumprir efeitos sobre a economia real.

Cinco conclusões emergem da avaliação geral dos instrumentos à luz das relações provocadas pelo modelo básico: i) as políticas econômicas específicas enxergam o sistema bancário de forma pontual, com relativo sucesso no objetivo principal da intervenção; ii) as política estruturais também alteram a dinâmica de ajustamento da economia; iii) os canais de crédito têm papel relevante na dinâmica e direcionam principalmente o investimento; iv) as interligações financeiras garantem que a propagação do sinal têm impactos sobre todo o arranjo econômico; e v) os efeitos vão além da conceito primário do instrumento, alcançando efeitos gerais sob 
outras perspectivas.

A observação das mudanças em três perspectivas de análise diferentes, mas integradas pelo modelo de equilíbrio geral, reconstrói algumas perguntas já feitas pela literatura, mas absortas pela tempestividade das intervenções atuais. Referem-se aos ganhos de escopo na coordenação das intervenções sob domínio econômico. A necessidade de coordenação das três áreas em uma instituição central de atuação monetária, regulação técnica e supervisão prudencial parece uma consequência óbvia com vistas a administrar os trade offs nas ações sobre o setor bancário. Políticas monetárias ativas requerem estabilidade regulatória.

Se o arcabouço institucional é condição necessária, não é suficiente para administrar o sistema financeiro. É iminente a construção de um paradigma teórico generalista que dê norte para a definição de políticas ótimas de intervenção sobre o setor bancário.

Os três instrumentos analisados não exaurem as possibilidades apresentadas pelo modelo. Pelo contrário, as intervenções analisadas foram assim escolhidas por representarem as regras mais renomadas associadas a cada um dos objetivos, com grande potencial explicativo do funcionamento do modelo DSGE. Todavia, diversos outros instrumentos podem ser avaliados sob a perspectiva multidisciplinar. Exemplos no campo da regulação técnica seriam políticas de homogeneização dos produtos de crédito, limites para as taxas de juros finais, tributação da indústria bancária, regulação da distribuição de dividendos e direcionamento setorial do crédito. Em termos de regulação prudencial, outras ferramentas tradicionais como a modelagem de seguros sobre depósitos, limites para as taxas de juros que remuneram os depósitos e limites para a alavancagem também podem ser objeto de estudo. No campo da Macroeconomia, seria interessante adaptar o modelo para investigar políticas de redesconto ou de remuneração do compulsório, ou novamente o direcionamento de crédito na economia. Regulamentações que interessam muito atualmente, como a reforma prudencial dos requerimentos de capital para conferir características contracíclicas ao instrumetno, também provocariam resultados interes- 
santes. Todas poderiam ser analisadas utilizando ${ }^{10}$ o mesmo framework e método de análise.

Sem dúvida os resultados obtidos são sensíveis às escolhas feitas durante a pesquisa, desde a modelagem ambiental, passando pela calibração dos parâmetros e pela definição de formas funcionais. Entretanto, o ponto principal do trabalho - a integração dos conceitos em um único modelo de equilíbrio geral - está acima dessas questões técnicas. Quaisquer que sejam os valores atribuídos aos parâmetros ou mesmo formas funcionais alternativas, a direção e o sentido dos resultados pode ser substancialmente afetada, mas a conexão construída será atuante. Dessa forma, são importantes os trabalhos de estimação de parâmetros e formas funcionais - um conjunto vasto de estudo já desempenhado por muitos artigos econômicos que estudam bancos -, mas a essência do trabalho não comprometida sob qualquer condição.

\footnotetext{
${ }^{10}$ As condições intrínsecas da pesquisa de doutorado limitam uma maior produção acadêmica nesse sentido. A prioridade foi mostrar os resultados para os instrumentos mais tradicionais. No capítulo 4 outros instrumentos serão mencionados como trabalhos futuros.
} 


\section{Capítulo 4}

\section{CONSIDERAÇÕES FINAIS}

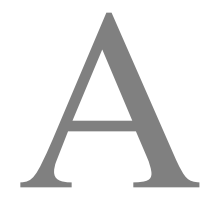

PERGUNTA DA TESE foi respondida pelo conjunto de observação e interpretação dos resultados da literatura, modelagem econômica e análise de equilíbrio geral, presentes nos

capítulos anteriores. Os objetivos de eficiência microeconômica bancária, resiliência do sistema financeiro e condução da estabilidade macroeconômica nas intervenções do Estado têm mensuração por relações endógenas em um equilíbrio geral dinâmico, no qual os bancos e a indústria bancária estão explicitamente descritos, razoavelmente detalhados e expostos a fricções diversas. Também foi cumprido o objetivo da tese de realçar a interação entre os conceitos quando da avaliação de políticas econômicas sobre o setor bancário. A ação de políticas de intervenção do Estado, sejam técnicas, prudenciais ou de política macro, modificam o comportamento ótimo dos bancos e alteram todos os objetivos subjacentes. Da constatação de que os bancos estão sobrerrepresentados no modelo, pode-se qualificar esta pesquisa como uma contribuição aos estudos em economia bancária (banking), política monetária, especificamente aos canais de transmissão, e regulação prudencial.

Se o capítulo 1 mostrou que a preocupação com os trade-offs entre os conceitos não é precisamente uma novidade nos textos econômicos, também se concluiu que o assunto ainda não está endereçado a contento, porque: i) os modelos existentes, a maioria ainda em equilíbrios parciais, registre-se, não são apropriados para analisar conjuntamente os três conceitos nem intervenções sobre o setor bancário; ii) os modelos mais completos analisam efeitos macro- 
econômicos das condições de competição, são também complexos e especializados em tratar particularidades das áreas a que pertencem, e não trabalham o vértice da solidez financeira; e iii) não é prioridade da pesquisa em Economia verificar interações e ruídos das intervenções quando ainda persistem grandes desafios na agenda macroeconômica.

O capítulo 2 construiu um modelo dinâmico de escala média em que fricções bancárias foram incorporadas ao conjunto de fricções usuais de modelos da Nova Síntese Neoclássica. As principais contribuições da tese em modelagem são: i) a composição das fricções financeiras com as características já tradicionais da literatura macro que está interessada nas fricções que afetam a política monetária; ii) a descrição específica e detalhada do mercado bancário em uma abordagem de intermediação financeira custosa; iii) a inclusão de capital bancário e a especificação de uma função de produção de crédito; e iv) a definição do comportamento ótimo do banco decorrente de um problema explícito de maximização intertemporal de lucros.

A produção dos bancos é definida em termos de depósitos e capital próprio, que são usados para criar crédito para famílias, firmas e empreendedores. A presença de capital bancário desempenha duas funções essenciais: i) recupera as relações patrimoniais do banco, o que permite a análise do passivo bancário e as relações de resiliência financeira; e ii) introduz uma não homogeneidade nos recursos do banco na produção de crédito. As taxas de juros do crédito precificam os custos operacionais de produção, os custos regulatórios e os custos de oportunidade, além de incluírem mark-ups setoriais.

Os resultados mostraram que os conceitos de eficiência bancária, resiliência financeira e estabilidade macroeconômica podem se comunicar em um único modelo de equilíbrio geral. Para os choques contracionistas de política monetária, por exemplo, o papel das fricções financeiras mostrou-se atenuador: os ajustamentos dos depósitos bancários e do capital próprio são diferentes e as condições de resiliência financeira se alteram no curto prazo; a depressão dos fatores de produção gera ganhos de eficiência, o que reduz os spreads; e a redução dos spreads conduz ao pass-through imperfeito de política monetária. 
Regulações do Estado entendidas em um sentido mais amplo - restrições técnicas, prudenciais e macroeconômicas - não são disciplinas estáticas e devem ser verificadas no escopo do setor bancário que as implementa. As análises do capítulo 3 exemplificam como a inclusão, bem como a intensidade, de ações de regulação podem constituir mudanças na operação da indústria bancária, as quais serão trasnsmitidas para a economia real pela atividade de intermediação financeira.

É possível sintetizar os resultados que surgem da análise dos instrumentos na perspectiva generalista dos conceitos, como foi desenvolvida na tese, tomando como referência ao modelo básico, em pontos muito simples: as políticas desenvolvidas por autoridades diferentes enxergam o sistema bancário de maneira fragmentada e, por isso, o sucesso no desempenho das intervenções pode ser considerado relativo. Sob uma perspectiva integrada, as políticas estruturais afetam o longo prazo, logicamente, mas também modificam a dinâmica de ajustamento da economia; nesta monografia, por exemplo, o foco esteve sobre os canais de crédito da transmissão de política monetária. Esses canais desempenham papel relevante na propagação do choque, porque modificam as condições de crédito que afetam principalmente o investimento da economia, como já argumentaram tantos artigos tradicionais. Mas se as fricções financeiras alteram o pass-through dos juros do crédito, também alteram a estrutura patrimonial das firmas bancárias e as condições estruturais da indústria. A contribuição da monografia é verificar como são afetadas as interligações financeiras que propagam o sinal para o arranjo real da economia e também como transformam o comportamento dos bancos. Os efeitos observados vão além do conceito base do instrumento, alcançando mudanças gerais sob outras perspectivas.

Verificar tais mudanças nas três perspectivas de análise, integradas pelo modelo de equilíbrio geral, reconstrói algumas perguntas já feitas pela literatura, mas absortas pela tempestividade e necessidade atual de intervenções sobre o setor. Essas perguntas referem-se a possíveis ganhos de escopo pela coordenação das intervenções sob o mercado bancário. A necessidade de coordenação das três áreas em uma instituição central de atuação monetária, regulação técnica e supervisão prudencial parece uma consequência óbvia com vistas a administrar os trade offs nas ações sobre o setor bancário. Políticas monetárias ativas requerem estabilidade regulatória. 
Se a organização institucional é condição necessária, não é suficiente para administrar o sistema financeiro. É iminente a consolidação de um paradigma teórico mais generalista que dê norte à definição de políticas ótimas de intervenção sobre o setor bancário.

O modelo consolidado nesta tese apresenta grande variedade de possibilidades de análise econômica, como é natural dos modelos DSGE, mas não é um modelo completo e definitivo. Uma das faltas de modelagem na integração dos conceitos é não encaminhar, por exemplo, a possibilidade de que o desenvolvimento da política monetária lidere efeitos persistentes e de longo prazo - não sobre o consumo e o produto, como tanto se pesquisa na literatura - mas sobre o comportamento do mercado bancário nos conceitos de eficiência e resiliência financeira. Também o modelo não desempenha a interação entre as medidas de resiliência e o processo decisório dos agentes, liderando outra falha na retroatividade dos conceitos. Ainda que sujeito à críticas, o desempenho do modelo em compor áreas diversas em um arcabouço atual, reconhecido e amplamente utilizado compensa esses fracassos.

O principal mérito da tese é efetuar realmente a convergência de campos de estudo adjacentes mas que ainda estão pouco interligados na literatura. Eficiência bancária, resiliência financeira e estabilidade macroeconômica são conceitos que trafegam pelo mesmo espaço econômico - o mercado bancário -, seja esse um meio de propagação ou o objetivo final para as ações de políticas econômicas. As consequências de regulações não coordenadas podem levar à indisposição do sistema econômico em produzir os resultados pretendidos pelo Estado. Conclui-se, mais geralmente, que não apenas a regulação forte é potencialmente não promotora de eficiência, mas também intervenções múltiplas em diferentes áreas pode produzir reações indesejáveis no comportamento bancário sob vários prismas de análise. A principal recomendação desta tese é propor uma perspectiva multidisciplinar e consolidada para a análise econômica quando da formatação de políticas públicas que perpassem pelo sistema financeiro.

As condições da pesquisa de doutorado obrigam a resolução de prioridades, de tal forma que um amplo conjunto de trabalhos que completaria a pesquisa no objeto proposto é direcionado para trabalhos futuros. 
As possibilidades do modelo permitem estudar outros instrumentos de intervenção em uma nova perspectiva multidisciplinar. A regulação técnica do setor bancário seria contemplada na análise de políticas de homogeneização dos produtos de crédito, price caps para as taxas finais de juros ao crédito, tributação da indústria, regulação da distribuição de dividendos e direcionamento setorial do crédito, todas ações tradicionais da teoria da regulação cujo comportamento no mercado bancário poderia ser avaliado de forma mais ampla. Ferramentas tradicionais também da regulação prudencial, como a modelagem de seguros sobre depósitos, limites para as taxas de juros que remuneram os depósitos e limites para a alavancagem, também podem ser objeto de estudo. No escopo da Macroeconomia, seria interessante adaptar o modelo para investigar políticas de redesconto e remuneração do compulsório ou também o crédito direcionado e verificar como o comportamento ótimo no curto prazo pode alterar os canais de crédito. As propostas atuais de requerimentos contracíclicos de capital bancário poderiam receber uma contribuição multidisciplinar.

Outro conjunto de trabalhos futuros está relacionado à estimação e à capacidade de previsão do modelo. Se os resultados são sensíveis aos parâmetros e formas funcionais, a relevância de um amplo estudo de estimação é irrevogável. As técnicas de estimação paramétrica e não paramétrica podem ser usadas para atualizar a literatura existente como também para especializar os resultados para a economia bancária brasileira.

As técnicas bayesianas de estimação estão sob trade-off entre estrutura econômica e identificação econométrica. Os resultados oferecidos por essa área de mensuração enfrentam relevantes problemas de identificação, principalmente para os parâmetros da indústria bancária. Especificamente os coeficientes de substituição da Cobb-Douglas para a firma bancária, os parâmetros da função custo e da lei de formação do capital bancário são fracamente identificados em estimação bayesiana com os dados agregados e simplificados que as pesquisas da área normalmente utilizam. Por tal motivo, estudos especializados em econometria frequencista podem também contribuir para a melhor calibração de parâmetros e garantir melhor acurácia na análise dos trade-offs. 
A ciência de que que trade-offs existem leva à pergunta sobre a melhor atuação do Estado sobre o setor bancário. A definição de uma política ótima não pode ser extraída do modelo apresentado sem que inclusão de mais estrutura econômica, especificamente desenhando a retroalimentação das medidas de resiliência na estrutura decisória dos agentes. Esse passo é essencial para a construção do problema de Ramsey que seja consistente em termos dos conceitos estudados. As vantagens da definição de uma política ótima de intervenção são imediatas na composição de políticas públicas eficientes em um escopo ampliado e multidisciplinar. 


\section{Referências Bibliográficas}

ADOLFSON, Malin; LASÉEN, Stefan; LINDÉ, Jesper; SVENSSON, Lars E O. Optimal Monetary Policy in an Operational Medium-Sized DSGE Model. [S.1.], Jul 2008. Disponível em: $<$ http://ideas.repec.org/p/cpr/ceprdp/6907.html $>$.

ALENCAR, Leonardo Soriano; NAKANE, Márcio Issao. Real Balances in the Utility Function: Evidence for Brazil. Brasília: Banco Central do Brasil, Fevereiro 2003. (Working Paper Series, 68).

. Bank Competition, Agency Costs and the Performance of the Monetary Policy. Brasília: Banco Central do Brasil, Janeiro 2004. (Working Paper Series, 81).

ALENCAR, Leonardo Soriano; NAKANE, Márcio Issao; KANCZUK, Fabio. Demand for Bank Services and Market Power in Brazilian Banking. Brasilia: Banco Central do Brasil, June 2006. (Working Paper Series, 107).

ALENCAR, Leonardo Soriano de. Concorrência Bancária, Custos de Agência e o Canal do Crédito da Política Monetária. 132 p. p. Tese (Doutorado em Economia) - Faculdade de Economia, Administração e Contabilidade, Universidade de São Paulo, São Paulo, 2002.

ALLEN, Franklin; GALE, Douglas. Optimal financial crises. Journal of Finance, v. 53, n. 4, p. 1245-1284, Aug. 1998. Disponível em: <http://ideas.repec.org/a/bla/jfinan/v53y1998i4p1245-1284.html>. $\overline{01177-8}$

Comparing Financial Systems. London, England: The MIT Press, 2000. ISBN 0-262-

Competition and financial stability. Journal of Money, Credit, and Banking, v. 36, n. 3, p. 1321-1338, 2004.

. Financial intermediaries and markets. Econometrica, v. 72, n. 4, p. 1023-1061, Jul. 2004. Disponível em: <http://ideas.repec.org/a/ecm/emetrp/v72y2004i4p1023-1061.html >.

ALTUNBAS, Y.; GARDENER, E. P. M.; MOLYNEUX, P.; MOORE, B. Efficiency in european banking. European Economic Review, v. 45, n. 10, p. 1931-1955, December 2001. Disponível em: < http://ideas.repec.org/a/eee/eecrev/v45y2001i10p1931-1955.html>.

ALTUNBAS, Yener; MOLYNEUX, Phil. Economies of scale and scope in european banking. Applied Financial Economics, v. 6, n. 4, p. 367-75, August 1996. Disponível em: <http://ideas.repec.org/a/taf/apfiec/v6y1996i4p367-75.html>.

ANDRÉS, Javier; ARCE, Óscar J. Banking Competition, Housing Prices and Macroeconomic Stability. jan. 2009. (Banco de España Working Papers, 0830). Mimeo. Disponível em: <http://ideas.repec.org/p/bde/wpaper/0830.html>.

AREND, Mario. MPRA Paper, Financial Shocks, Financial Frictions and Financial Intermediaries in DSGE Models: Comments on the Recent Literature. maio 2010. Disponível em: $<$ http://ideas.repec.org/p/pra/mprapa/22957.html $>$. 
ASLAM, Aqib; SANTORO, Emiliano. Bank Lending, Housing and Spreads. maio 2008. (Discussion Papers, 08-27). Disponível em: <http://ideas.repec.org/p/kud/kuiedp/0827.html >.

BARTH, James R.; CAPRIO, Gerard; LEVINE, Ross. Do Regulation and Ownership Affect Performance and Stability? Washington: The World Bank, April 2000. (Policy Research Working Paper, 2325).

The Regulation and Supervision of Banks around the World: a new database. Washington: The World Bank, April 2001. (Policy Research Working Paper, 2588).

Bank regulation and supervision: what works best? Cambridge: National Bureau of Economic Research, November 2002. (NBER Working Paper Series, 9323). Disponível em: $<$ http://www.nber.org/papers/w9323>.

The microeconomic effects of different approaches to bank supervision. Draft June 2, $\overline{2005}$. June 2005.

BARTH, James R.; CAPRIO JR., Gerard; LEVINE, Ross. Rethinking Bank Regulation. New York, NY: Cambridge University Press, 2006. ISBN 0521855764.

BECK, Thorsten; DEMIRGUÇ-KUNT, Asli; LEVINE, Ross. Bank Concentration and Crises. National Bureau of Economic Research, Inc, ago. 2003. (NBER Working Papers, 9921). Disponível em: <http://www.nber.org/papers/w9921 >.

BENSTON, George J.; KAUFMAN, George G. Is the banking and payments system fragile? Journal of Financial Services Research, v. 9, p. 209-40, 1995.

BENVENISTE, Lawrence M.; SCHEINKMAN, José Alexandre. On the differentiability of the value function in dynamic models of economics. Econometrica, v. 47, n. 3, p. 727-32, May 1979. Disponível em: <http://ideas.repec.org/a/ecm/emetrp/v47y1979i3p727-32.html >.

BERNANKE, Ben S; BLINDER, Alan S. The federal funds rate and the channels of monetary transmission. American Economic Review, v. 82, n. 4, p. 901-21, September 1992. Disponível em: <http://ideas.repec.org/a/aea/aecrev/v82y1992i4p901-21.html >.

BERNANKE, Ben Shalom; BLINDER, Alan S. Credit, money, and aggregate demand. The American Economic Review, v. 78, n. 2, p. 435-439, 1988.

BERNANKE, Ben Shalom; GERTLER, Mark. Agency costs, net worth, and business fluctuations. The American Economic Review, v. 79, n. 1, p. 14-31, 1989.

Inside the black box: The credit channel of monetary policy transmission. Journal of Economic Perspectives, v. 9, n. 4, p. 27-48, Fall 1995. Disponível em: < http://ideas.repec.org/a/aea/jecper/v9y1995i4p27-48.html>.

BERNANKE, Ben Shalom; GERTLER, Mark; GILCHRIST, Simon. The financial accelerator in a quantitative business cycle framework. In: TAYLOR, J. B.; WOODFORD, M. (Ed.). Handbook of Macroeconomics. [S.1.]: Elsevier, 1999. cap. 21, p. 1341-1393.

BLANCHARD, Olivier Jean; KAHN, Charles M. The solution of linear difference models under rational expectations. Econometrica, v. 48, n. 5, p. 1305-11, July 1980. Disponível em: $<$ http://ideas.repec.org/a/ecm/emetrp/v48y1980i5p1305-11.html $>$.

CALVO, Guilhermo A. Staggered prices in a utility-maximizing framework. Journal of Monetary Economics, n. 12, p. 383-98, 1983.

CANZONERI, Matthew; CUMBY, Robert E.; DIBA, Behzad; LOPEZ-SALIDO, David. Monetary Aggregates and Liquidity in a Neo-Wicksellian Framework. [S.1.], ago. 2008. Disponível em: <http://ideas.repec.org/p/nbr/nberwo/14244.html>. 
CARLSTROM, Charles; FUERST, Timothy. Agency costs, net worth, and business fluctuations: A computable general equilibrium analysis. American Economic Review, v. 87, p. 893910, 1997.

CARNEIRO, Dionísio Dias; WERNECK, Rogério Ladeira F.; GARCIA, Márcio Gomes Pinto; BONOMO, Marco. Brazil. In: Strengthening the Financial Sector in the adjustment process. Washington: Inter-American Development Bank, 1994.

CHRISTENSEN, Ian; CORRIGAN, P.; MENDICINO, C.; NISHIYAMA, S. An Estimated Open-Economy General Equilibrium Model with Housing Investment and Financial Frictions. 2007. Mimeo.

CHRISTIANO, Lawrence; EICHENBAUM, Martin. Liquidity effects, monetary policy, and the business cycle. Journal of Money, Credit and Banking, v. 27, n. 4, p. 1113-36, November 1995. Disponível em: <http://ideas.repec.org/a/mcb/jmoncb/v27y1995i4p1113-36.html>.

CHRISTIANO, Lawrence; EICHENBAUM, Martin; EVANS, Charles. Nominal rigidities and the dynamic effects of a shock to monetary policy. Journal of Political Economy, v. 113, n. 1, p. 1-45, February 2005. Disponível em: <http://ideas.repec.org/a/ucp/jpolec/v113y2005i1p145.html $>$.

CHRISTIANO, Lawrence; MOTTO, Roberto; ROSTAGNO, Massimo. Financial factors in business cycles. (Preliminary). November 2007.

COSTA, Ana Carla Abrão. Ensaios em Microeconomia Bancária. Tese (Doutorado em Economia) - Faculdade de Economia, Administração e Contabilidade, Universidade de São Paulo, São Paulo, 2004.

CURDIA, Vasco; WOODFORD, Michael. Credit Frictions and Optimal Monetary Policy. 2008. Disponível em: <http://ideas.repec.org/p/clu/wpaper/0809-02.html >.

CYSNE, Rubens Penha. Is There a Price Puzzle in Brazil? An Application of Bias-Corrected Bootstrap. dez. 2004. (Economics Working Papers (Ensaios Economicos da EPGE), 577). Disponível em: < http://ideas.repec.org/p/fgv/epgewp/577.html $>$.

DEGRYSE, Hans; KIM, Moshe; ONGENA, Steven. Microeconometrics of Banking: Methods, Applications, and Results. New York, NY: Oxford University Press, 2009. ISBN 9780195340471.

DEMSETZ, Harold. Why regulate utilities? Journal of Law and Economics, v. 11, n. 1, p. 55-65, 1968.

DEMSETZ, Rebecca S.; SAIDENBERG, Marc R.; STRAHAN, Philip E. Banks with something to lose: the disciplinary role of franchise value. Economic Policy Review, n. Oct, p. 1-14, 1996. Disponível em: < http://ideas.repec.org/a/fip/fednep/y1996ioctp1-14nv.2no.2.html $>$.

DIAMOND, D.; DYBVIG, P. Bank runs, deposit insurance, and liquidity. Journal of Political Economy, v. 91, p. 401-19, June 1983.

DIAMOND, Douglas W.; RAJAN, Raghuram G. Liquidity risk, liquidity creation, and financial fragility: A theory of banking. Journal of Political Economy, v. 109, n. 2, p. 287-327, April 2001. Disponível em: <http://ideas.repec.org/a/ucp/jpolec/v109y2001i2p287-327.html >.

. Money in a theory of banking. American Economic Review, v. 96, n. 1, p. 30-53, March 2006. Disponível em: <http://ideas.repec.org/a/aea/aecrev/v96y2006i1p30-53.html>.

DIAZ-GIMENEZ, Javier; PRESCOTT, Edward C.; FITZGERALD, Terry; ALVAREZ, Fernando. Banking in computable general equilibrium economies. Journal of Economic Dynamics and Control, v. 16, n. 3-4, p. 533-559, 1992. Disponível em: <http://ideas.repec.org/a/eee/dyncon/v16y1992i3-4p533-559.html>. 
EDWARDS, Sebastian; VEGH, Carlos A. Banks and macroeconomic disturbances under predetermined exchange rates. Journal of Monetary Economics, v. 40, n. 2, p. 239-278, October 1997. Disponível em: <http://ideas.repec.org/a/eee/moneco/v40y1997i2p239-278.html >.

FAMA, Eugene. Banking in theory of finance. Journal of Monetary Economics, v. 9, n. 1, p. 39-58, 1980.

FIORE, Fiorella De; UHLIG, Harald. Bank Finance versus Bond Finance - What Explains the Differences between US and Europe? European Central Bank, nov. 2005. (Working Paper Series, 547). Disponível em: < http://ideas.repec.org/p/ecb/ecbwps/20050547.html >.

FREIXAS, Xavier; ROCHET, Jean-Charles. Microeconomics of Banking. Cambridge, Massachusetts and London, England: MIT Press, 1997. ISBN 0-262-06193-7. $\overline{262-06270-1 .}$

. 2nd. ed. Cambridge, MA and London, England: MIT Press, 2008. ISBN 978-0-

FRIEDMAN, Milton. The Quantity Theory of Money: A Restatement. [S.1.]: Chicago University Press, 1956.

FRIEDMAN, Milton; SCHWARTZ, Anna J. A Monetary History of the United States, 18671960. National Bureau of Economic Research, Inc, 1963. Disponível em: < http://econpapers.repec.org/RePEc:nbr:nberbk:frie63-1>.

FUERST, Timothy S. Monetary and financial interactions in the business cycle. Journal of Money, Credit, and Banking, n. 27, p. 1321-1338, 1995.

GALE, Douglas; HELLWIG, Martin. Incentive-compatible debt contracts: the one-period problem. Review of Economic Studies, n. 52, p. 647-663, 1985.

GALE, Douglas; VIVES, Xavier. Dollarization, bailouts, and the stability of the banking system. The Quarterly Journal of Economics, v. 117, n. 2, p. 467-502, May 2002. Disponível em: $<$ http://ideas.repec.org/a/tpr/qjecon/v117y2002i2p467-502.html $>$.

GALLOWAY, Tina M.; LEE, Winson B.; RODEN, Dianne M. Banks' changing incentives and opportunities for risk taking. Journal of Banking and Finance, v. 21, n. 4, p. 509-527, 1997. Disponível em: <http://econpapers.repec.org/RePEc:eee:jbfina:v:21:y:1997:i:4:p:509-527>.

GERALI, Andrea; NERI, Stefano; SESSA, Luca; SIGNORETTI, Federico M. Credit and banking in a dsge model of the euro area. Journal of Money, Credit and Banking, v. 42, n. s1, p. 107-141, 09 2010. Disponível em: <http://ideas.repec.org/a/mcb/jmoncb/v42y2010is1p107141.html>.

GERTLER, Mark; KIYOTAKI, Nobuhiro. Financial Intermediation and Credit Policy in Business Cycle Analysis. Oct 2009. Mimeo.

GOODFRIEND, Marvin; KING, Robert G. The New Neoclassical Synthesis and the Role of Monetary Policy. Federal Reserve Bank of Richmond, 1998. (Working Paper, 98-05). Disponível em: <http://ideas.repec.org/p/fip/fedrwp/98-05.html >.

GOODFRIEND, Marvin; MCCALLUM, Bennett T. Banking and interest rates in monetary policy analysis: A quantitative exploration. Journal of Monetary Economics, v. 54, n. 5, p. 14801507, July 2007. Disponível em: <http://ideas.repec.org/a/eee/moneco/v54y2007i5p14801507.html >.

GRAMINHO, Flávia Mourão; BONOMO, Marco. O canal de empréstimos bancários no brasil: Uma evidência microeconômica. In: XXX ENCONTRO NACIONAL DE ECONOMIA, XXX., 2002, Nova Friburgo. Anais do XXX Encontro Nacional de Economia. Nova Friburgo: ANPEC, 2002. 
GURLEY, John; SHAW, Edward. Financial aspects of economic development. The American Economic Review, v. 45, n. 4, September 1955.

HALL, Simon. Financial Accelerator Effects in UK Business Cycles. Bank of England, dez. 2001. (Bank of England Working Papers, 150). Disponível em: $<$ http://ideas.repec.org/p/boe/boeewp/150.html>.

HELLMAN, Thomas; MURDOCK, Kevin; STIGLITZ, Joseph. Liberatization, moral hazard in banking, and prudential regulation: Are capital requirements enough? The American Economic Review, v. 90, n. 1, p. 147-65, 2000.

HODRICK, Robert J; PRESCOTT, Edward C. Postwar u.s. business cycles: An empirical investigation. Journal of Money, Credit and Banking, v. 29, n. 1, p. 1-16, February 1997. Disponível em: <http://ideas.repec.org/a/mcb/jmoncb/v29y1997i1p1-16.html>.

HUMPHREY, David B. Flow versus stock indicators of banking output: Effects on productivity and scale economy measurement. Journal of Financial Services Research, Springer Netherlands, v. 6, p. 115-135, 1992. ISSN 0920-8550. 10.1007/BF01046626. Disponível em: <http://dx.doi.org/10.1007/BF01046626>.

IACOVIELLO, Matteo. Household debt and income inequality, 1963-2003. Journal of Money, Credit and Banking, v. 40, n. 5, p. 929-965, 08 2008. Disponível em: <http://ideas.repec.org/a/mcb/jmoncb/v40y2008i5p929-965.html>.

KANCZUK, Fabio. Real interest rates and brazilian business cycles. Review of Economic Dynamics, v. 7, n. 2, p. 436-455, April 2004. Disponível em: < http://ideas.repec.org/a/red/issued/v7y2004i2p436-455.html>.

KASHYAP, Anil K.; STEIN, Jeremy C. Monetary policy and bank lending. In: MANKIW, N. Gregory (Ed.). NBER Studies in Business Cycles. Chicago: University of Chicago Press, 1994. v. 29.

. What do a million observations on bank say about the transmission of monetary policy? American Economic Review, v. 90, n. 3, p. 407-428, June 2000.

KEELEY, Michael. Deposit insurance, risk and market power in banking. American Economic Review, n. 80, p. 1183-1200, 1990.

KEYNES, John Maynard. The General Theory of Employment, Interest and Money. London: Macmillan, 1936.

KIYOTAKI, Nobuhiro; MOORE, John. Credit cycles. Journal of Political Economy, v. 105, n. Feb., p. 211-48, April 1997. Disponível em: < http://ideas.repec.org/a/ucp/jpolec/v105y1997i2p211-48.html>.

KOCHERLAKOTA, Narayana. Model fit and model selection. Federal Reserve Bank of St. Louis Review, n. Jul, p. 349-360, 2007. Disponível em: <http://ideas.repec.org/a/fip/fedlrv/y2007ijulp349-360nv.89no.4.html>.

LEEPER, Eric M. Equilibria under "active" and "passive' monetary and fiscal policies. Journal of Monetary Economics, v. 27, n. 1, p. 129-147, February 1991. Disponível em: < http://ideas.repec.org/a/eee/moneco/v27y1991i1p129-147.html>.

LEVIN, Andrew T.; NATALUCCI, Fabio M.; ZAKRAJSEK, Egon. The magnitude and cyclical behavior of financial market frictions. Board of Governors of the Federal Reserve System (U.S.), 2004. (Finance and Economics Discussion Series, 2004-70). Disponível em: <http://ideas.repec.org/p/fip/fedgfe/2004-70.html>.

LEVIN, Andrew T.; ONATSKI, Alexei; WILLIAMS, John C.; WILLIAMS, Noah. Monetary Policy under Uncertainty in Micro-founded Macroeconometric Models. Federal Reserve Bank of San Francisco, 2005. (Working Papers in Applied Economic Theory, 2005-15). Disponível em: <http://ideas.repec.org/p/fip/fedfap/2005-15.html $>$. 
LUCAS JR., Robert Ellery. Econometric policy evaluation: A critique. Carnegie-Rochester Conference Series on Public Policy, v. 1, n. 1, p. 19-46, January 1976. Disponível em: <http://ideas.repec.org/a/eee/crcspp/v1y1976ip19-46.html>.

. Macroeconomic priorities. American Economic Review, v. 93, n. 1, p. 1-14, March 2003. Disponível em: <http://ideas.repec.org/a/aea/aecrev/v93y2003i1p1-14.html >.

MARTINS, Bruno Silva. Calibrando e Simulando o Modelo do "Acelerador Financeiro" para a Economia Brasileira. Tese (Dissertação de Mestrado) — EPGE/Fundação Getúlio Vargas, Rio de Janeiro, 2007.

MATUTES, Carmen; VIVES, Xavier. Imperfect competition, risk taking, and regulation in banking. European Economic Review, v. 44, n. 1, p. 1-34, April 2000.

MAZIERO, Priscila; NAKANE, Marcio Issao. Impacts of interest rate policies in a small open economy with working capital constraints. In: XXIV ENCONTRO BRASILEIRO DE ECONOMETRIA, 24., 2002, Nova Friburgo. Anais... Rio de Janeiro: Sociedade Brasileira de Econometria, 2002.

McGRATTAN, Ellen R.; PRESCOTT, Edward C. Taxes, regulations, and the value of u.s. and u.k. corporations. Review of Economic Studies, v. 72, n. 3, p. 767-796, 07 2005. Disponível em: <http://ideas.repec.org/a/bla/restud/v72y2005i3p767-796.html >.

MISHKIN, Frederic Stanley. Symposium on the monetary transmission mechanism. Journal of Economic Perspectives, v. 9, n. 4, p. 3-10, Fall 1995. Disponível em: <http://ideas.repec.org/a/aea/jecper/v9y1995i4p3-10.html>.

. The Channels of Monetary Transmission: Lessons for Monetary Policy. Chicago, May 1996. Disponível em: <http://ideas.repec.org/p/nbr/nberwo/5464.html>.

MODIGLIANI, Franco; MILLER, Merton H. The cost of capital, corporation finance and the theory of investment. The American Economic Review, v. 48, n. 3, p. 261-297, June 1958.

MUINHOS, Marcelo Kfoury; ALVES, Sergio Afonso Lago. Medium-Size Macroeconomic Model for the Brazilian Economy. Brasília: Banco Central do Brasil, Fevereiro 2003. (Working Paper Series, 64).

OLIVEIRA, Fernando Nascimento de; NETO, Renato da Motta Andrade. A relevância do canal de empréstimos bancários no brasil. Revista Brasileira de Finanças, v. 6, n. 3, p. 357409, 2008.

PUGA, Fernando Pimentel. Sistema financeiro brasileiro: Reestruturação recente, comparações internacionais e vulnerabilidade à crise cambial. In: Anos 90. Rio de Janeiro: BNDES, 1999. . A Economia Brasileira nos

ROCHA, Bruno de Paula. Ensaios sobre Economia Bancária e Política Monetária no Brasil em uma Abordagem Regionalizada. Tese (Tese de Doutorado) - Universidade de São Paulo, São Paulo, 2007.

ROMER, Christina Duckworth; ROMER, David. New evidence on the monetary transmission mechanism. Brookings Papers on Economic Activity, v. 21, n. 1990-1, p. 149-214, 1990. Disponível em: <http://econpapers.repec.org/RePEc:bin:bpeajo:v:21:y:1990:i:1990-1:p:149-214>.

SANTOS, João A. C. Bank Capital Regulation In Contemporary Banking Theory: A Review of the Literature. set. 2000. (BIS Working Papers, 90). Disponível em: $<$ http://ideas.repec.org/p/bis/biswps/90.html >.

SAPPINGTON, David E. M. Designing incentive regulation. Review of Industrial Organization, n. 9, p. 245-72, 1994. 
SARGENT, Thomas J.; WALLACE, Neil. Some unpleasant monetarist arithmetic. Quarterly Review, n. Fall, 1981. Disponível em: < http://ideas.repec.org/a/fip/fedmqr/y1981ifallnv.5no.3.html>.

SBORDONE, Argia M.; COGLEY, Timothy. A search for a structural phillips curve. Computing in Economics and Finance, n. 291, ago. 2004. Disponível em: < http://ideas.repec.org/p/sce/scecf4/291.html >.

SCHMITT-GROHÉ, Stephanie; URIBE, Martin. Optimal Fiscal and Monetary Policy in a Medium-Scale Macroeconomic Model: Expanded Version. [S.1.], jun. 2005. Disponível em: $<\mathrm{http}: / /$ ideas.repec.org/p/nbr/nberwo/11417.html $>$.

SEALEY CALVIN W, Jr; LINDLEY, James T. Inputs, outputs, and a theory of production and cost at depository financial institutions. Journal of Finance, v. 32, n. 4, p. 1251-66, September 1977. Disponível em: <http://ideas.repec.org/a/bla/jfinan/v32y1977i4p1251-66.html>.

SIMS, Christopher A. Interpreting the macroeconomic time series facts : The effects of monetary policy. European Economic Review, v. 36, n. 5, p. 975-1000, June 1992. Disponível em: $<$ http://ideas.repec.org/a/eee/eecrev/v36y1992i5p975-1000.html $>$.

SMETS, Frank; WOUTERS, Rafael. An estimated dynamic stochastic general equilibrium model of the euro area. Journal of the European Economic Association, v. 1, n. 5, p. 1123-1175, 09 2003. Disponível em: < http://ideas.repec.org/a/tpr/jeurec/v1y2003i5p1123-1175.html>.

Shocks and frictions in us business cycles: A bayesian dsge approach. American Economic Review, v. 97, n. 3, p. 586-606, June 2007. Disponível em: < http://ideas.repec.org/a/aea/aecrev/v97y2007i3p586-606.html>.

SMITH, Todd R. Banking competition and macroeconomic performance. Journal of Money, Credit, and Banking, n. 30, p. 793-815, 1998.

SOBRINHO, Nelson F. Souza; NAKANE, Marcio Issao. Uma avaliação do canal de crédito no brasil. In: XXX ENCONTRO NACIONAL DE ECONOMIA, XXX., 2002, Nova Friburgo. Anais do XXX Encontro Nacional de Economia. Nova Friburgo: ANPEC, 2002.

SOBRINHO, Nelson Ferreira Souza. Uma avaliação do canal de crédito no brasil. Prêmio BNDES de Economia, n. 25, 2003.

STIGLITZ, Joseph; WEISS, Andrew. Credit rationing in markets with imperfect information. American Economic Review, v. 71, n. 3, p. 393-421, 1981.

. Asymmetric information in credit markets and its implication for macro-economics. $O x$ ford Economic Papers, n. 44, p. 694-724, 1992.

TAKEDA, Tony; ROCHA, Fabiana; NAKANE, Márcio. The reaction of bank lending to monetary policy in brazil. In: Anais do XXXI Encontro Nacional de Economia. Porto Seguro: ANPEC, 2003.

TANAKA, Misa. How Do Bank Capital and Capital Adequacy Regulation Affect the Monetary Transmission Mechanism? 2002. (CESifo Working Paper Series, 799). Disponível em: <http://ideas.repec.org/p/ces/ceswps/n̆derline 799.html>.

TCHANA, Fulbert. The Welfare Cost of Banking Regulation. out. 2007. (MPRA Paper, 7588). Disponível em: <http://ideas.repec.org/p/pra/mprapa/7588.html $>$.

TOBIN, James. Commercial Banks as Creators of "Money". New Haven, 1963. Disponível em: <http://ideas.repec.org/p/cwl/cwldpp/159.html $>$.

TOVAR, Camilo Ernesto. DSGE models and central banks. Bank for International Settlements, set. 2008. (BIS Working Papers, 258). Disponível em: < http://ideas.repec.org/p/bis/biswps/258.html>. 
TOWNSEND, R. M. Optimal contracts and competitive markets with costly state verification. Journal of Economic Theory, n. 21, p. 265-293, 1979.

WOODFORD, Michael. Interest and Prices - Foundations of a Theory of Monetary Policy. Princeton, New Jersey: Princeton University Press, 2003. ISBN 0-691-01049-8. 


\section{APÊNDICES}

A MODELO COM FRICÇÕES FINANCEIRAS

B SOLUÇÃO DO MODELO DSGE

C EXTENSÕES DO MODELO BÁSICO 


\section{Apêndice A}

\section{MODELO COM FRICÇÕES FINANCEIRAS}

\section{A.1 Famílias}

\section{A.1.1 O Problema da Família Representativa}

São variáveis de controle o consumo corrente $C$, as horas trabalhadas $H$, os saldos monetários reais $M / P$, os depósitos bancários $D$ com liquidação no período seguinte, os títulos públicos $B$ com liquidação no período seguinte e os ativos livres de risco $A$. As variáveis de estado são o consumo do período anterior $C_{-1}$, pois há persistência do hábito, e as decisões passadas de moeda, depósitos, títulos públicos e títulos livres de risco. Seja $V\left(C_{-1}, M_{-1}, D_{-1}, B_{-1}, A_{-1}\right)$ a função valor do problema de maximização. Ajustando a notação, a equação de Bellman abaixo descreve o problema de escolha intertemporal de consumo, trabalho e poupança da família representativa. $Z$ é equivalente a $R_{l(j)}$. 


\section{Problema A.1Problema da Família}

$$
\begin{aligned}
\text { maximizar } V= & U\left(C-b C_{-1} ; H ; M / P, D, B\right)+\beta E V^{\prime} \\
\text { escolhendo } & (C, H, M, D, B, A) \\
\text { sujeito a } & \text { Restrição orçamentária, eq. (2.5) } \\
& {\left[\lambda_{1}\right] \quad C+\frac{M}{P}+D+B+A+Z_{-1} \bar{L}=\left(1-\tau^{h}\right) W H+\bar{L} } \\
& +\frac{M_{-1}}{P}+R_{-1}^{b} B_{-1}+R_{-1}^{d} D_{-1}+R_{-1} A_{-1} \\
& +V^{\text {ban }}+V^{\text {emp }}+V^{f i r}+T
\end{aligned}
$$

A formulação de Bellman simplificada será assim:

$$
\begin{aligned}
& V\left(C_{-1}, M_{-1}, D_{-1}, B_{-1}, A_{-1}\right)= U\left(C-b C_{-1} ; H ; M / P, D, B\right) \\
&+\lambda_{1}\left\{\left(1-\tau^{h}\right) W H+\frac{M_{-1}}{P}+R_{-1}^{b} B_{-1}+R_{-1}^{d} D_{-1}+R_{-1} A_{-1}\right. \\
&+ \\
&\left.+\bar{L}+V^{\text {ban }}+V^{\text {emp }}+V^{f i r}+T\right\} \\
&\left.-\left(C+\frac{M}{P}+D+B+A+Z \bar{L}\right)\right\} \\
&+\beta E V(C, M, D, B, A)
\end{aligned}
$$

As condições de primeira ordem (CPO) para o problema são sete:

$$
\begin{aligned}
U_{C}+\beta E V_{C} & =\lambda_{1} \\
U_{H}+\lambda_{1}\left(1-\tau^{h}\right) W & =0 \\
\frac{U_{M / P}}{P}+\beta E V_{M} & =\frac{\lambda_{1}}{P} \\
U_{D}+\beta E V_{D} & =\lambda_{1} \\
U_{B}+\beta E V_{B} & =\lambda_{1} \\
\beta E V_{A} & =\lambda_{1}
\end{aligned}
$$


As condições de Benveniste \& Scheinkman (1979) (BS - uma aplicação do Teorema do Envelope) são:

$$
\begin{aligned}
V_{C_{-1}} & =-b U_{C} \\
V_{M_{-1}} & =\frac{\lambda_{1}}{P} \\
V_{D_{-1}} & =\lambda_{1} R_{-1}^{d} \\
V_{B_{-1}} & =\lambda_{1} R_{-1}^{b} \\
V_{A_{-1}} & =\lambda_{1} R_{-1}
\end{aligned}
$$

Trazendo as condições BS um período à frente e atualizando as CPOs:

$$
\begin{aligned}
U_{C}-\beta b U_{C^{\prime}} & =\beta \lambda_{1} \\
\lambda_{1}\left(1-\tau^{h}\right) W & =-U_{H} \\
\frac{\lambda_{1}}{P} & =\frac{U_{M / P}}{P}+\beta E \lambda_{1}^{\prime} \frac{1}{P^{\prime}} \\
U_{D}+\beta E \lambda_{1}^{\prime} R^{d} & =\lambda_{1} \\
U_{B}+\beta E \lambda_{1}^{\prime} R^{b} & =\lambda_{1} \\
\beta E \lambda_{1}^{\prime} R & =\lambda_{1}
\end{aligned}
$$

A taxa de juros livre de risco define o preço-sombra da restrição orçamentária:

$$
\beta E \frac{\lambda_{1}^{\prime}}{\lambda_{1}}=E \frac{1}{R}
$$

\section{A.1.2 Euler Equation}

A CPO para o consumo indica que a família consome até o nível em que o ganho marginal de utilidade é igual ao custo de oportunidade da remuneração do ativo livre de risco que é 
adquirido com a unidade de consumo. Desenvolvendo a equação de Euler, a partir da CPO para o consumo:

$$
\begin{aligned}
U_{C}-\beta b U_{C^{\prime}} & =\lambda_{1} \\
U_{C^{\prime}}-\beta b U_{C^{\prime \prime}} & =\lambda_{1}^{\prime} \\
\frac{U_{C}-\beta b U_{C^{\prime}}}{U_{C^{\prime}}-\beta b U_{C^{\prime \prime}}} & =\beta R_{t}=\frac{\lambda_{1}}{\lambda_{1}^{\prime}}
\end{aligned}
$$

O custo marginal líquido de uma unidade de consumo, em termos de utilidade, deverá ser igual ao ganho líquido de postergar essa unidade de consumo. Adiar o consumo corrente significa aumentar a acumulação de ativos correntes, percebendo retorno no período seguinte. A razão de troca intertemporal de consumo entre dois períodos subsequentes deve ser igual à razão do ganho líquido de transferir o consumo para o período seguinte. Esse ganho líquido advém da remuneração de ativos.

\section{A.1.3 A Demanda por Moeda}

A condição de primeira ordem para a moeda pode ser trabalhada:

$$
\frac{U_{M / P}}{\lambda_{1}}=1-\beta E \frac{\lambda_{1}^{\prime}}{\lambda_{1}} \frac{1}{\pi^{\prime}}
$$

$\beta \frac{\lambda_{1}^{\prime}}{\lambda_{1}}$ é o preço em termos de utilidade de postergar consumo para o período seguinte. Usando a CPO do consumo, obtém-se a taxa marginal de substituição entre consumo e moeda que explica a demanda por saldos monetários por motivos transacionais quando o retorno da moeda é dominado pelos ativos que rendem juros:

$$
\frac{U_{M / P}}{U_{C}-\beta b E U_{C^{\prime}}}=1-\frac{1}{R} E \frac{1}{\pi^{\prime}}
$$

Aqui, como no consumo e lazer, há trade-off entre consumo de bens e moeda. A condição de ótimo que determina a demanda por moeda garante que a família acumula saldos reais até que 
o benefício marginal seja igual ao custo líquido real de oportunidade em termos de utilidade de aplicar em outras formas de ativos, por exemplo o ativo livre de risco.

\section{A.1.4 Oferta de Trabalho}

Tome a CPO para horas trabalhadas. Fazendo as substituições necessárias:

$$
\begin{aligned}
\lambda_{1}\left(1-\tau^{h}\right) W & =-U_{H} \\
\frac{-U_{H}}{U_{C}-\beta b E U_{C^{\prime}}} & =W\left(1-\tau^{h}\right)
\end{aligned}
$$

O consumo dispensado reduz o valor total da cesta, diminuindo a demanda dos indivíduos por crédito além de migrar alguns indivíduos da condição de tomadores de crédito para poupadores líquidos. Então o salário real líquido de imposto define plenamente a substituição entre consumo e lazer:

\section{A.1.5 Escolha Ótima de Ativos}

Para os depósitos bancários, com $R>R^{d}$, a demanda por depósitos bancários será:

$$
\begin{aligned}
U_{D}+\beta E \lambda_{1}^{\prime} R^{d} & =\lambda_{1} \\
\frac{U_{D}}{\lambda_{1}} & =1-\beta E \frac{\lambda_{1}^{\prime}}{\lambda_{1}} R^{d} \\
\frac{U_{D}}{\lambda_{1}} & =1-\frac{R^{d}}{R} \\
\frac{U_{D}}{U_{C}-\beta b E U_{C^{\prime}}} & =\frac{R-R^{d}}{R}
\end{aligned}
$$

De forma equivalente, para os títulos públicos:

$$
\begin{aligned}
\frac{U_{B}}{U_{C}-\beta b E U_{C^{\prime}}} & =\frac{R-R^{b}}{R} \\
\frac{U_{D}}{U_{B}} & =\frac{R-R^{d}}{R-R^{b}}
\end{aligned}
$$


Em equilíbrio, $R=R^{b}$ e a demanda por por títulos público é irrestrita. Ou seja, não há custo de oportunidade.

\section{A.2 Firmas}

\section{A.2.1 O Problema da Firma}

\section{Problema A.2Problema da Firma}

maximizar $\quad P_{i, t}\left(\frac{P_{i, t}}{P_{t}}\right)^{-\eta} Y_{t}-P_{t}\left(R_{t}^{k}-1\right) k_{t}^{d}-\left[1+\nu\left(\int_{0}^{1} R_{b, t}^{l}\left(\frac{R_{b, t}^{l}}{R_{t}^{l}}\right)^{-\vartheta} d b-1\right)\right] P_{t} W_{t} h_{t}^{d}$ $\left(k_{t}^{d}, h_{t}^{d}\right)$

sujeito a Demanda pelo bem intermediário, eq. (2.17)

$$
\left[P_{t} \Omega_{i, t}\right] \quad z_{t} F\left(k_{t}^{d}, h_{t}^{d}\right)-\psi \geq\left(\frac{P_{i, t}}{P_{t}}\right)^{-\eta} Y_{t}
$$

Seja $P_{t} \Omega_{i, t}$ o multiplicador de Lagrange associado à restrição do problema. $\Omega_{i, t}$ pode ser interpretado com o custo marginal real de produção da firma $i$. As condições de primeira ordem associadas aos fatores capital e trabalho são:

$$
\begin{aligned}
\left(R_{t}^{k}-1\right) & =\Omega_{i, t} z_{t} F_{k}\left(k_{t}^{d}, h_{t}^{d}\right) \\
W_{t} & =\Omega_{i, t} \frac{z_{t} F_{h}\left(k_{t}^{d}, h_{t}^{d}\right)}{1+\nu\left(\int_{0}^{1} R_{b, t}^{l}\left(\frac{R_{b, t}^{l}}{R_{t}^{l}}\right)^{-\vartheta} d b-1\right)}
\end{aligned}
$$

Como todas as firmas se defrontam com os mesmos preços de fatores e todas têm acesso à mesma tecnologia de produção $F$ homogênea de grau um, os custos marginais devem ser iguais para todas as firmas produtoras de variedades de bens intermediários, isto é, $\sigma_{i t}=\sigma_{t}, \forall i$. Matematicamente isso também é óbvio porque as condições de primeira ordem acima devem ser atendidas para todas as firmas $i \in[0,1]$. 


\section{A.2.2 O Problema da Firma sob Rigidez de Preços}

Problema A.3Problema da Firma sob Rigidez de Preços

maximizar $\quad E_{t} \sum_{s=0}^{\infty} \alpha_{f}^{s} r_{t, t+s} P_{t+s}\left\{\left(\frac{\tilde{P}_{t}}{P_{t}}\right)^{1-\eta} \prod_{k=1}^{s}\left(\frac{\pi_{t+k-1}^{\chi_{f}}}{\pi_{t+k}}\right)^{1-\eta} Y_{t+s}-\left(R_{t+s}^{k}-1\right) P_{t} k_{t+s}^{d}\right.$

$$
\left.-P_{t} W_{t+s} h_{t+s}^{d}\left[1+\nu\left(\int_{0}^{1} R_{b, t+s}^{l}\left(\frac{R_{b, t+s}^{l}}{R_{t+s}^{l}}\right)^{-\vartheta} d b-1\right)\right]\right\}
$$

sujeito a Demanda pelo bem intermediário

$$
\left[\alpha_{f}^{s} r_{t, t+s} P_{t+s} \Omega_{i, t+s}\right] \quad z_{t+s} F\left(k_{t+s}^{d}, h_{t+s}^{d}\right)-\psi \geq\left(\frac{\tilde{P}_{t}}{P_{t}}\right)^{-\eta} \prod_{k=1}^{s}\left(\frac{\pi_{t+k-1}^{\chi_{f}}}{\pi_{t+k}}\right)^{-\eta} Y_{t+s}
$$

A condição de primeira ordem é:

$$
E_{t} \sum_{s=0}^{\infty} r_{t+s} \alpha_{f}^{s} P_{t+s}\left(\frac{\tilde{P}_{t}}{P_{t}}\right)^{-\eta} \prod_{k=1}^{s}\left(\frac{\pi_{t+k-1}^{\chi_{f}}}{\pi_{t+k}}\right)^{-\eta} Y_{t+s}\left[\frac{\eta-1}{\eta}\left(\frac{\tilde{P}_{t}}{P_{t}}\right) \prod_{k=1}^{s}\left(\frac{\pi_{t+k-1}^{\chi_{f}}}{\pi_{t+k}}\right)-\Omega_{i, t+s}\right]=0
$$

Porque a expressão é computacionalmente inadequada, é normal transformá-la em uma formulação recursiva. Define-se:

$$
\begin{gathered}
x_{t}^{1} \equiv E_{t} \sum_{s=0}^{\infty} r_{t, t+s} \alpha_{f}^{s} Y_{t+s} \Omega_{i, t+s}\left(\frac{\tilde{P}_{t}}{P_{t}}\right)^{-\eta-1} \prod_{k=1}^{s}\left(\frac{\pi_{t+k-1}^{\chi_{f}}}{\pi_{t+k}^{(1-\eta) / \eta}}\right)^{-\eta} \\
x_{t}^{2} \equiv E_{t} \sum_{s=0}^{\infty} r_{t, t+s} \alpha_{f}^{s} Y_{t+s}\left(\frac{\tilde{P}_{t}}{P_{t}}\right)^{-\eta} \prod_{k=1}^{s}\left(\frac{\pi_{t+k-1}^{\chi_{f}}}{\pi_{t+k}^{\eta /(\eta-1)}}\right)^{1-\eta} \\
\frac{\tilde{P}_{t}}{P_{t}}=\tilde{p}_{t}
\end{gathered}
$$


A condição de ótimo para o preço da firma em concorrência monopolística é resumida pelo bloco:

$$
\begin{aligned}
\eta x_{t}^{1} & =(\eta-1) x_{t}^{2} \\
x_{t}^{1} & =Y_{t} \Omega_{t} \tilde{p}_{t}^{-\eta-1}+\alpha_{f} E_{t} r_{t, t+1} \pi_{t+1}\left(\frac{\tilde{p}_{t}}{\tilde{p}_{t+1}}\right)^{-\eta-1}\left(\frac{\pi_{t}^{\chi_{f}}}{\pi_{t+1}}\right)^{-\eta} x_{t+1}^{1} \\
x_{t}^{2} & =Y_{t} \tilde{p}_{t}^{-\eta}+\alpha_{f} E_{t} r_{t, t+1} \pi_{t+1}\left(\frac{\tilde{p}_{t}}{\tilde{p}_{t+1}}\right)^{-\eta}\left(\frac{\pi_{t}^{\chi_{f}}}{\pi_{t+1}}\right)^{1-\eta} x_{t+1}^{2}
\end{aligned}
$$

\section{A.2.3 Agregação}

Em equilíbrio simétrico, firmas que conseguem mudar preço em um determinado instante do tempo sempre escolherão o mesmo preço. Da definição do índice de preços da equação (2.4) obtém-se:

$$
1=\alpha_{f} \pi_{t}^{\eta-1} \pi_{t-1}^{\chi_{f}(1-\eta)}+\left(1-\alpha_{f}\right) \tilde{p}_{t}^{1-\eta}
$$

Tome agora a equação de oferta de bens. Agregando todas as firmas e levando em conta que a relação capital trabalho é a mesma para todas a firmas e a demanda agregada de capital é um composto de capital físico dos empreendedores, tem-se:

$$
\begin{aligned}
z_{t} F\left(k_{t}^{d}, h_{t}^{d}\right)-\psi & =\left(\frac{P_{i, t}}{P_{t}}\right)^{-\eta} Y_{t} \\
z_{t} H_{t}^{d} F\left(\frac{K_{t}^{d}}{H_{t}^{d}}, 1\right)-\psi & =Y_{t} \int_{0}^{1}\left(\frac{P_{i, t}}{P_{t}}\right)^{-\eta} d i
\end{aligned}
$$


Mas:

$$
\begin{aligned}
s_{t} & =\int_{0}^{1}\left(\frac{P_{i, t}}{P_{t}}\right)^{-\eta} d i \\
& =\left(1-\alpha_{f}\right)\left(\frac{\tilde{P}_{t}}{P_{t}}\right)^{-\eta}+\left(1-\alpha_{f}\right) \alpha_{f}\left(\frac{\tilde{P}_{t-1} \pi_{t-1}^{\chi_{f}}}{P_{t}}\right)^{-\eta}+\left(1-\alpha_{f}\right) \alpha_{f}^{2}\left(\frac{\tilde{P}_{t-2} \pi_{t-1}^{\chi_{f}} \pi_{t-2}^{\chi_{f}}}{P_{t}}\right)^{-\eta}+\ldots \\
s_{t} & =\left(1-\alpha_{f}\right) \sum_{j=0}^{\infty} \alpha_{f}^{j}\left(\frac{\tilde{P}_{t-j} \prod_{s=1}^{j} \pi_{t-j-1+s}^{\chi_{f}}}{P_{t}}\right)^{-\eta} \\
s_{t} & =\left(1-\alpha_{f}\right) \tilde{p}_{t}^{-\eta}+\alpha_{f}\left(\frac{\pi_{t}}{\pi_{t-1}^{\chi_{f}}}\right)^{\eta} s_{t-1}
\end{aligned}
$$

Portanto:

$$
\begin{aligned}
z_{t} H_{t}^{d} F\left(\frac{K_{t}^{d}}{H_{t}^{d}}, 1\right)-\psi & =Y_{t} s_{t} \\
s_{t} & =\left(1-\alpha_{f}\right) \tilde{p}_{t}^{-\eta}+\alpha_{f}\left(\frac{\pi_{t}}{\pi_{t-1}^{\chi_{f}}}\right)^{\eta} s_{t-1}
\end{aligned}
$$

com $s_{-1}$ dado.

O lucro da firma em termos nominais é dado pela equação (2.16). Então, o lucro da indústria em termos reais é derivado assim:

$$
\begin{aligned}
& P_{t} \Pi_{t}=\int_{0}^{1} P_{i, t}\left(\frac{P_{i, t}}{P_{t}}\right)^{-\eta} Y_{t} d i-P_{t}\left(R_{t}^{k}-1\right) K_{t}^{d}-P_{t} W_{t} H_{t}^{d}-\left(R_{i, t}^{l}-1\right) P_{t} L_{t}^{(i)} \\
& P_{t} \Pi_{t}=\left[\alpha_{f} P_{t-1} \pi_{t-1}^{\chi_{f}}+\left(1-\alpha_{f}\right) \tilde{P}_{t}\right] \int_{0}^{1}\left(\frac{P_{i, t}}{P_{t}}\right)^{-\eta} Y_{t} d i-\left(R_{t}^{k}-1\right) K_{t}^{d}-W_{t} H_{t}^{d}-\left(R_{i, t}^{l}-1\right) L_{t}^{(i)} \\
& P_{t} \Pi_{t}=Y_{t} s_{t}\left[\alpha_{f} P_{t-1} \pi_{t-1}^{\chi_{f}}+\left(1-\alpha_{f}\right) \tilde{P}_{t}\right]-P_{t}\left(R_{t}^{k}-1\right) K_{t}^{d}-P_{t} W_{t} H_{t}^{d}-\left(R_{i, t}^{l}-1\right) P_{t} L_{t}^{(i)} \\
& P_{t} \Pi_{t}=P_{t} Y_{t} s_{t}\left[\alpha_{f} \pi_{t-1}^{\chi_{f}-1}+\left(1-\alpha_{f}\right) \tilde{p}_{t}\right]-\left(R_{t}^{k}-1\right) K_{t}^{d}-W_{t} H_{t}^{d}-\left(R_{i, t}^{l}-1\right) L_{t}^{(i)}
\end{aligned}
$$

$$
\Pi_{t}=Y_{t} s_{t}\left[\alpha_{f} \pi_{t-1}^{\chi_{f}-1}+\left(1-\alpha_{f}\right) \tilde{p}_{t}\right]-\left(R_{t}^{k}-1\right) K_{t}^{d}-W_{t} H_{t}^{d}-\left(R_{i, t}^{l}-1\right) L_{t}^{(i)}
$$




\section{A.3 Produtores de Capital}

\section{Problema A.4Problema do Produtor de Capital}

maximizar $\quad E_{t} \sum_{s=0}^{\infty} r_{t, t+s}\left\{\tilde{Q}_{t+s}\left[x_{t+s}+i_{t+s}\left[1-\mathcal{S}\left(\frac{i_{t+s}}{i_{t+s-1}}\right)\right]\right]-\tilde{Q}_{t+s} x_{t+s}-P_{t+s} i_{t+s}\right\}$ $\left\{i_{t+s}\right\}_{s=0}^{\infty}$

$\operatorname{Dados} P_{t+s}, \tilde{Q}_{t+s}, x_{t+s}, i_{t+s-1}$.

Em termos reais, $Q_{t}=\tilde{Q}_{t} / P_{t}$, a função objetivo simplificada é:

$$
E_{t} \sum_{s=0}^{\infty} r_{t, t+s}\left\{Q_{t+s} i_{t+s}\left[1-\mathcal{S}\left(\frac{i_{t+s}}{i_{t+s-1}}\right)\right]-i_{t+s}\right\}
$$

A condição de primeira ordem do problema de maximização irrestrita para o investimento corrente $i_{t}$ é dada por:

$$
Q_{t}\left[1-\mathcal{S}_{t}-\frac{i_{t}}{i_{t-1}} \mathcal{S}_{t}^{\prime}\right]+E_{t} r_{t, t+1} Q_{t+1}\left(\frac{i_{t+1}}{i_{t}}\right)^{2} \mathcal{S}_{t+1}^{\prime}=1
$$

A condição de ótimo esclarece a demanda por investimento será tal que o custo marginal do bem final deve ser igual aos ganho marginal da unidade de investimento. Qualquer valor do estoque de capital é consistente com a maximização de lucros. Em estado estacionário $Q=1$ $\mathrm{e} i=\delta k$.

Produtores de capital idênticos distribuídos no espaço unitário demandam a mesma quantidade de bens finais. A agregação é trivial. A demanda agregada para investimento é $I_{t}=i_{t}, \forall t$, 
assim o estoque de capital agregado fica $K_{t}=k_{t}$.

$$
\begin{aligned}
1 & =Q_{t}\left[1-\mathcal{S}\left(\frac{I_{t}}{I_{t-1}}\right)-\frac{I_{t}}{I_{t-1}} S^{\prime}\left(\frac{I_{t}}{I_{t-1}}\right)\right]+E_{t} r_{t, t+1} Q_{t+1}\left(\frac{I_{t+1}}{I_{t}}\right)^{2} S^{\prime}\left(\frac{I_{t+1}}{I_{t}}\right) \\
K_{t+1} & =\underbrace{(1-\delta) K_{t}}_{X_{t}}+I_{t}\left[1-\mathcal{S}\left(\frac{I_{t}}{I_{t-1}}\right)\right]
\end{aligned}
$$

\section{A.4 Empreendedores}

\section{A.4.1 O Contrato Financeiro}

O contrato financeiro de investimento realizado período a período entre empreendedor e banco é bem definido pelo vetor $\left(\bar{\kappa}, R_{b, t}^{l}, l_{b, t}\right)$, tal que:

Problema A.5Contrato Financeiro de Investimento

1. Dados $\left(R_{t}^{k}, R_{t}^{l}, \tau_{t}^{k}, k_{t}, n_{t}\right)$, a demanda total de crédito do empreendedor e o seu nível crítico de solvência são respectivamente iguais a:

$$
\begin{aligned}
l_{t}^{d} & =Q_{t} k_{t}-n_{t} \\
\bar{\kappa} & =\frac{R_{t}^{l}}{E_{t} Q_{t+1}\left[\left(1-\tau_{t}^{k}\right)\left(R_{t}^{k}-1\right)+(1-\delta)\right]} \frac{l_{t}^{d}}{k_{t}}
\end{aligned}
$$

2. Dados $\left(R_{t}^{k}, \Phi(\kappa), \mu, Z_{t}, \gamma\right)$, a oferta de crédito de cada banco b neutro a risco a um mesmo empreendedor deve atender a condição de participação do banco.

3. $\quad$ Market-clearing

$$
\int_{0}^{1} l_{b, t} d b=l_{t}^{d}
$$


Em equilíbrio parcial, o banco $b$ vai ofertar crédito sempre que o retorno do empréstimo ao empreendedor for igual ao custo de oportunidade de emprestar o mesmo volume de crédito à taxa bruta $Z_{t+1}$ no mercado livre de risco.

$$
\begin{aligned}
(1-\gamma)\left\{\int_{0}^{\bar{\kappa}}\left[\kappa E_{t} Q_{t+1} x_{t}-V\left(\kappa E_{t} Q_{t+1} x_{t}\right)\right] d \Phi(\kappa)\left(\frac{R_{b, t}^{l}}{R_{t}^{l}}\right)^{-\vartheta}\right. & \\
\left.+[1-\Phi(\bar{\kappa})] R_{b, t}^{l} l_{b, t}\right\} & =Z_{t} l_{b, t} \quad \forall b
\end{aligned}
$$

Como o retorno do banco $b$ é equivalente ao custo de oportunidade tomando em um mercado livre de risco no qual todos os bancos operam, os retornos esperados de todos os bancos serão iguais para um mesmo empreendedor. Os bancos oferecem o mesmo contrato financeiro em equilíbrio parcial:

$$
\begin{aligned}
R_{b, t}^{l} & =R_{t}^{l} \\
l_{b, t}^{d} & =l_{t}^{d}
\end{aligned}
$$

Então:

$$
(1-\gamma) E_{t} Q_{t+1} x_{t}\left\{[1-\Phi(\bar{\kappa})] \bar{\kappa}+(1-\mu) \int_{0}^{\bar{\kappa}} \kappa d \Phi(\kappa)\right\}=Z_{t} l_{t}
$$

As equações (2.27), (2.28), (2.30), (2.31), (A.5) e (2.33) determinam de forma única o contrato financeiro $\left(\bar{\kappa}, R_{b, t+1}^{l}, l_{b, t}\right)$.

Agora é possível reescrever (A.6), usando (2.28) e (2.27):

$$
R_{t}^{l}=\underbrace{\left[\frac{\bar{\kappa}}{(1-\gamma)\left\{[1-\Phi(\bar{\kappa})] \bar{\kappa}+(1-\mu) \int_{0}^{\bar{\kappa}} \kappa d \Phi(\kappa)\right\}}\right]}_{\text {prêmio de risco } \tilde{s}(\bar{\kappa})} Z_{t}
$$


Defina a função prêmio de risco esperado $\tilde{s}(\bar{\kappa})$, para $\kappa>0$.

$$
\tilde{s}(\bar{\kappa})=\frac{\bar{\kappa}}{(1-\gamma)\{[1-\Phi(\bar{\kappa})] \bar{\kappa}+(1-\mu) \mathcal{H}(\bar{\kappa})\}}
$$

$\operatorname{Com} \mathcal{H}(x)=\int_{0}^{x} \kappa \psi(\kappa) d \kappa=E[\kappa \mid \kappa>x] P[\kappa>x]$.

\section{A.4.2 Agregação}

Os empreendedores que morrem transferem sua riqueza líquida para as famílias. Dentre os sobreviventes, os empreendedores inadimplentes têm riqueza zero porque o banco audita e toma toda a riqueza residual. Apenas sobreviventes adimplentes possuem riqueza líquida, após a quitação do contrato financeiro. A fração $\gamma$ de empreendedores que nascem em $t$ e os empreendedores sobreviventes inadimplentes no período receberão a transferência de parte dos lucros das firmas. A riqueza líquida agregada dos empreendedores é:

$N_{t}=(1-\gamma) Q_{t}\left[\left(1-\tau_{t-1}^{k}\right)\left(R_{t-1}^{k}-1\right)+(1-\delta)\right] K_{t-1}\left\{1-\mathcal{H}\left(\bar{\kappa}_{t-1}\right)-\bar{\kappa}_{t-1}\left[1-\Phi\left(\bar{\kappa}_{t-1}\right)\right]\right\}+F_{t}$

Para um dado nível ótimo de solvência, igual para todos os empreendedores, as demandas agregadas de crédito e capital são conhecidas:

$$
\begin{aligned}
L_{t} & =v\left(\bar{\kappa}^{*}\right) K_{t} \\
Q_{t} K_{t}-L_{t} & =N_{t}
\end{aligned}
$$

A riqueza líquida apurada de empreendedores que morrem em $t$ é transferida para as famílias:

$$
V_{t}^{e m p}=\gamma Q_{t}\left[\left(1-\tau_{t-1}^{k}\right)\left(R_{t-1}^{k}-1\right)+(1-\delta)\right] K_{t-1}
$$




\section{A.5 Bancos}

\section{A.5.1 O Problema do Banco}

Problema A.6Problema do Banco

$$
\begin{array}{cl}
\text { maximizar } & E_{t} \sum_{s=1}^{\infty} r_{\bar{t}, t+s} \Pi_{b, t+s}^{b a n} \\
\text { escolhendo } & \left\{R_{b, t}^{l(j)}, R_{b, t}^{l(e)}, R_{b, t}^{l(i)}, R_{b, t}^{l(x)}, l_{b, t}^{(j)}, l_{b, t}^{(e)}, l_{b, t}^{(i)}, l_{b, t}^{(x)}, m_{t}, a_{t}, b_{t}, d_{t}, b c_{t}, i_{t}, \Delta_{t}\right\}_{t=0}^{\infty}
\end{array}
$$

sujeito a Balanço patrimonial, eq. (2.36)

$$
\left[\lambda_{1}\right] \quad l_{b, t}+\frac{m_{t}}{P_{t}}+b_{t}+a_{t}=d_{t}+b c_{t}+i_{t}+\mathcal{K}_{t}
$$

Tecnologia bancária, eq. (2.39)

$\left[\lambda_{2}\right] \quad z_{\mathcal{T} t} \mathcal{T}\left(d_{t}, \mathcal{K}_{t}\right) \geq l_{b, t}$

Liquidez para pagamentos, eq. (2.42)

$\left[\lambda_{3}\right] \quad \frac{m_{t-1}}{P_{t}}+b c_{t}+i_{t} \geq \mathcal{P}_{t}\left(d_{t-1} ; \varepsilon_{\mathcal{P}}\right)$

Oferta agregada de crédito, eq. (2.37)

$$
[\sigma] \quad l_{b, t}=l_{b, t}^{(j)}+l_{b, t}^{(e)}+l_{b, t}^{(i)}+l_{b, t}^{(x)}
$$

Demandas de crédito devem ser atendidas

$$
\left[\sigma_{(.)}\right] \quad l_{b, t}^{(.)} \geq l_{t}^{d(.)}\left(\frac{R_{b, t}^{l(.)}}{R_{t}^{l(.)}}\right)^{-\theta_{(.), t}}, \quad(.) \in\{j, e, i, x\}
$$

Dados $\quad \mathcal{P}_{t}, \mathcal{K}_{t}, m_{t}$

Processo estocástico da tecnologia, eq. (2.40)

$$
\ln z_{\mathcal{T} t}=\rho_{z_{\mathcal{T}}} \ln z_{\mathcal{T} t-1}+\epsilon^{z \mathcal{T} t}
$$

Lei de de pagamentos, eq. (2.43)

$$
\mathcal{P}_{t}=F\left(d_{t-1}, \varepsilon_{\mathcal{P} t}\right)
$$

Lei de formação do capital próprio, eq. (2.38)

$$
\mathcal{K}_{b, t+1}=(1-\omega) \mathcal{K}_{b, t}+\Delta_{b, t}+\Theta_{t} \Pi_{b, t+1}
$$


O problema pode ser escrito por uma formulação de Bellman na qual são variáveis de estado o capital próprio do período atual $\mathcal{K}_{t}$, o nível mínimo de liquidez para pagamentos requerido no período $\mathcal{P}_{t}$ e os saldos monetários nominais correntes $m_{t}$. Defina a função valor $\mathfrak{V}$ (que é igual ao Charter Value) no tempo $t$. Seja $\Lambda_{t}$ o fator de desconto variante no tempo, conforme definição posterior. Ajustando a notação:

$$
\begin{aligned}
& \mathfrak{V}\left(\mathcal{K}, \mathcal{P}, m_{-1}\right)=\operatorname{Er}^{\prime}\left\{\left[\int_{0}^{1} \Pi_{b}^{(j)} d j+\int_{0}^{1} \Pi_{b}^{\prime(e)} d e+\int_{0}^{1} \Pi_{b}^{\prime(i)} d i+\int_{0}^{1} \Pi_{b}^{\prime(x)} d x\right.\right. \\
& \left.\left\{R_{b}^{l(j)}, R_{b}^{l(e)}, R_{b}^{l(i)}, R_{b}^{l(x)}, \quad \quad+R a+R^{b} b+\frac{m}{P^{\prime}}-\left(R^{d} d+R^{b c} b c+R^{i} i+\mathcal{K}+\Delta+\mathcal{C}\left(d, l_{b}\right)\right)\right]\right\} \\
& l_{b}, l_{b}^{(j)}, l_{b}^{(e)}, l_{b}^{(i)}, l_{b}^{(x)}, \quad+\lambda_{1}\left[d+b c+i+\mathcal{K}-l_{b}-\frac{m}{P}-b-a\right] \\
& m, b, a, d, b c, i, \Delta\} \quad+\lambda_{2}\left[z_{\mathcal{T}} \mathcal{T}(d, \mathcal{K})-l_{b}\right] \\
& +\lambda_{3}\left[\frac{m_{-1}}{P}+b c+i-\mathcal{P}\left(d_{-1} ; \varepsilon\right)\right] \\
& +\sigma\left[l_{b}-l_{b}^{(j)}-l_{b}^{(e)}-l_{b}^{(i)}-l_{b}^{(x)}\right] \\
& +\sigma_{j}\left[l_{b}^{(j)}-l^{d(j)}\left(\frac{R_{b}^{l(j)}}{R^{l(j)}}\right)^{-\theta_{j, t}}\right]+\sigma_{e}\left[l_{b}^{(e)}-l^{d(e)}\left(\frac{R_{b}^{l(e)}}{R^{l(e)}}\right)^{-\theta_{e, t}}\right]+ \\
& +\sigma_{i}\left[l_{b}^{(i)}-l^{d(i)}\left(\frac{R_{b}^{l(i)}}{R^{l(i)}}\right)^{-\theta_{i, t}}+\sigma_{x}\left[l_{b}^{(x)}-l^{d(x)}\left(\frac{R_{b}^{l(x)}}{R^{l(x)}}\right)^{-\theta_{x, t}}\right]\right. \\
& +E \mathfrak{V}\left(\mathcal{K}^{\prime}, \mathcal{P}^{\prime}, m\right)
\end{aligned}
$$

sendo:

$$
\begin{aligned}
\int_{0}^{1} \Pi_{b}^{\prime(j)} d e & =\int_{0}^{1} l^{d(j)}\left(\frac{R_{b}^{l(j)}}{R^{l(j)}}\right)^{-\theta_{j, t}} R_{b}^{l(j)} d j \\
\int_{0}^{1} \Pi_{b}^{\prime(e)} d e & =\int_{0}^{1} l^{d(e)}\left(\frac{R_{b}^{l(e)}}{R^{l(e)}}\right)^{-\theta_{e, t}} R_{b}^{l(e)} \frac{1}{s(\bar{\kappa})} d e \\
\int_{0}^{1} \Pi_{b}^{\prime(i)} d e & =\int_{0}^{1} l^{d(i)}\left(\frac{R_{b}^{l(i)}}{R^{l(i)}}\right)^{-\theta_{i, t}} R_{b}^{l(i)} d i \\
\int_{0}^{1} \Pi_{b}^{\prime}(x) d e & =\int_{0}^{1} l^{d(x)}\left(\frac{R_{b}^{l(x)}}{R^{l(x)}}\right)^{-\theta_{x, t}} R_{b}^{l(x)} d x \\
l_{b} & =\int_{0}^{1} l_{b}^{(j)} d j+\int_{0}^{1} l_{b}^{(e)} d e+\int_{0}^{1} l_{b}^{(x)} d x+\int_{0}^{1} l_{b}^{(i)} d i
\end{aligned}
$$


As condições de primeira ordem são dezesseis:

1. Juros do crédito ao empreendedor

$$
\frac{\frac{R_{b}^{l(e)}}{\tilde{s}(\bar{\kappa})}-\frac{1}{\Lambda} \sigma_{e}}{\frac{R_{b}^{l(e)}}{\tilde{s}(\bar{\kappa})}}=\frac{1}{\varepsilon_{R_{b}^{l(e)}}}=\frac{1}{\theta_{e, t}}
$$

2. Juros do crédito ao consumidor

$$
\frac{R_{b}^{l(j)}-\frac{1}{\Lambda} \sigma_{j}}{R_{b}^{l(j)}}=\frac{1}{\varepsilon_{R_{b}^{l(j)}}}=\frac{1}{\theta_{j, t}}
$$

3. Juros do crédito às firmas

$$
\frac{R_{b}^{l(i)}-\frac{1}{\Lambda} \sigma_{i}}{R_{b}^{l(i)}}=\frac{1}{\varepsilon_{R_{b}^{l(i)}}}=\frac{1}{\theta_{i, t}}
$$

4. Juros do crédito interbancário

$$
\frac{R_{b}^{l(x)}-\frac{1}{\Lambda} \sigma_{x}}{R_{b}^{l(x)}}=\frac{1}{\varepsilon_{R_{b}^{l(x)}}}=\frac{1}{\theta_{x, t}}
$$

5. Empréstimo aos consumidores

$$
\sigma=\sigma_{j}
$$

6. Empréstimo aos empreendedores

$$
\sigma=\sigma_{e}
$$

7. Empréstimo às firmas

$$
\sigma=\sigma_{i}
$$


8. Empréstimo aos bancos

$$
\sigma=\sigma_{x}
$$

9. Empréstimos totais

$$
\lambda_{1}+\lambda_{2}+\Lambda \mathcal{C}_{l}=\sigma
$$

10. Moeda

$$
\Lambda E \frac{1}{P^{\prime}}+E \mathfrak{V}_{m}=\frac{\lambda_{1}}{P}
$$

11. Ativo livre de risco

$$
\Lambda R=\lambda_{1}
$$

12. Títulos públicos

$$
\Lambda R^{b}=\lambda_{1}
$$

13. Depósitos bancários

$$
\Lambda\left(R^{d}+\mathcal{C}_{d}\right)-E \mathfrak{V}_{\mathcal{P}^{\prime}} \mathcal{P}^{\prime}{ }_{d}=\lambda_{1}+\lambda_{2} z_{\mathcal{T}} \mathcal{T}_{d}
$$

14. Redesconto

$$
\Lambda R^{b c}=\lambda_{1}+\lambda_{3}
$$

15. Empréstimo Interbancário

$$
\Lambda R^{i}=\lambda_{1}+\lambda_{3}
$$


16. Capitalização

$$
-\Lambda+E \mathfrak{V}_{\mathcal{K}^{\prime}}=0
$$

Portanto, $\frac{1}{\Lambda} \sigma_{e}=\Sigma_{e}$ representa o curto marginal real de ofertar uma unidade de crédito aos empreendedores. $\Lambda=E r^{\prime}+E \mathfrak{V}_{\mathcal{K}^{\prime}} \Theta$ é o valor presente do lucro marginal futuro. A dinâmica de acumulação do capital bancário garante que $\Lambda \geq 1 / R$.

As condições de Benveniste \& Scheinkman (1979) para o problema do banco são três: capital bancário, nível de liquidez para pagamentos e moeda:

$$
\mathfrak{V}_{\mathcal{K}}=-E r^{\prime}+\lambda_{1}+\lambda_{2} z_{\mathcal{T}} \mathcal{T}_{\mathcal{K}}+E \mathfrak{V}_{\mathcal{K}^{\prime}}(1-\omega)
$$

$\mathfrak{V}_{\mathcal{P}}=\lambda_{3}$

(A.15)

$$
\mathfrak{V}_{m_{-1}}=\lambda_{3} \frac{1}{P}
$$


Ajustando as condições de primeira ordem, lembrando $\Sigma=\frac{\sigma}{\Lambda}$ :

$$
\frac{R_{b}^{l(.)}-\Sigma_{(.)}}{R_{b}^{l(.)}}=\frac{1}{\varepsilon_{R_{b}^{l(.)}}}=\frac{1}{\theta_{(.), t}} \quad(.) \in\{j, i, x\}
$$

$$
\frac{\frac{R_{b}^{l(e)}}{s(\bar{\kappa})}-\Sigma_{e}}{\frac{R_{b}^{l(e)}}{s(\bar{\kappa})}}=\frac{1}{\varepsilon_{R_{b}^{l(e)}}}=\frac{1}{\theta_{e}}
$$

$$
\sigma=\sigma_{j}=\sigma_{e}=\sigma_{i}=\sigma_{x}
$$

$$
\Sigma=\frac{\lambda_{1}}{\Lambda}+\frac{\lambda_{2}}{\Lambda}+\mathcal{C}_{l}
$$

$$
\Lambda E \frac{1}{\pi^{\prime}}+E \frac{1}{\pi^{\prime}} \lambda_{3}^{\prime}=\lambda_{1}
$$

$$
R=\frac{\lambda_{1}}{\Lambda}
$$

$$
R^{b}=\frac{\lambda_{1}}{\Lambda}, \quad b>0
$$

$$
\Lambda\left(R^{d}+\mathcal{C}_{d}\right)+E \lambda_{3}^{\prime} \mathcal{P}^{\prime}{ }_{d}=\lambda_{1}+\lambda_{2} z_{\mathcal{T}} \mathcal{T}_{d}
$$

$$
\begin{aligned}
R^{b c} & =\frac{\lambda_{3}}{\Lambda}+\frac{\lambda_{1}}{\Lambda}, \quad b c>0 \\
R^{i} & =\frac{\lambda_{3}}{\Lambda}+\frac{\lambda_{1}}{\Lambda}, \quad i>0
\end{aligned}
$$

$$
\Lambda=E \mathfrak{V}_{\mathcal{K}^{\prime}}, \quad \Delta>0
$$

$\operatorname{Com} \Lambda=E r^{\prime}+E \mathfrak{V}_{\mathcal{K}^{\prime}} \Theta$.

\section{A.5.2 Prova da Proposição 2.1}

Proposição 2.1. Todos os empréstimos devem ter retornos esperados iguais quando as elasticidadesjuros da demanda forem iguais.

Prova. A proposição decorre diretamente das condições de primeira ordem quando se assume solução interior para todos os mercados de crédito. Os custos marginais reais de ofertar crédito são iguais para todos os mercados:

$$
\begin{aligned}
\lambda_{1}+\lambda_{2}+\Lambda \mathcal{C}_{l}= & \sigma \\
& \sigma=\sigma_{j}=\sigma_{e}=\sigma_{i}=\sigma_{x}
\end{aligned}
$$


Portanto, pelas condições de otimalidade para os juros e supondo que a elasticidade-juros da demanda é a mesma, os retornos devem ser iguais em todos os mercados de crédito:

$$
R_{b, t}^{l(j)}=\frac{R_{b, t}^{l(e)}}{s(\bar{\kappa})}=R_{b, t}^{l(i)}=R_{b, t}^{l(x)}, \text { se } \theta_{j, t}=\theta_{e, t}=\theta_{i, t}=\theta_{x, t} .
$$

\section{A.5.3 Prova da Proposição 2.2}

Proposição 2.2. Sejam dois mercados de crédito com diferentes elasticidades-juros da demanda. Então vale:

$$
\begin{aligned}
R_{b, t}^{l(j)} & =\frac{\theta_{j, t}}{\theta_{x, t}} \frac{\left(\theta_{x, t}-1\right)}{\left(\theta_{j, t}-1\right)} R_{b, t}^{l(x)} \\
\frac{R_{b, t}^{l(e)}}{s(\bar{\kappa})} & =\frac{\theta_{e, t}}{\theta_{x, t}} \frac{\left(\theta_{x, t}-1\right)}{\left(\theta_{e, t}-1\right)} R_{b, t}^{l(x)} \\
R_{b, t}^{l(i)} & =\frac{\theta_{i, t}}{\theta_{x, t}} \frac{\left(\theta_{x, t}-1\right)}{\left(\theta_{i, t}-1\right)} R_{b, t}^{l(x)}
\end{aligned}
$$

Prova. Sejam as condições de primeira ordem para dois mercados de créditos quaisquer:

$$
\frac{Z_{1}-\frac{1}{\Lambda} \sigma}{Z_{1}}=\frac{1}{\varepsilon_{Z_{1}}} \quad \frac{Z_{2}-\frac{1}{\Lambda} \sigma}{Z_{2}}=\frac{1}{\varepsilon_{Z_{2}}}
$$

As taxas de juros ótimas são função do custo marginal real do banco, que é igual em todos os mercados, e da elasticidade-juros. Assim:

$$
Z_{1}-\frac{Z_{1}}{\varepsilon_{Z_{1}}}=Z_{1}\left(1-\frac{1}{\varepsilon_{Z_{1}}}\right)=\frac{1}{\Lambda} \sigma
$$


$1-1 / \varepsilon_{Z_{1}}$ é o markup do monopolista no mercado de crédito. O resultado é clássico na literatura de poder de mercado: quanto maior a elasticidade da demanda, menor será o markup, e o preço cobrado pela firma monopolista será equivalente ao custo marginal real de produção. Prosseguindo:

$$
\begin{aligned}
Z_{1}\left(1-\frac{1}{\varepsilon_{Z_{1}}}\right) & =Z_{2}\left(1-\frac{1}{\varepsilon_{Z_{2}}}\right) \\
\frac{Z_{1}}{Z_{2}} & =\frac{1-\frac{1}{\varepsilon_{Z_{2}}}}{1-\frac{1}{\varepsilon_{Z_{1}}}}=\frac{\varepsilon_{Z_{1}}}{\varepsilon_{Z_{2}}} \frac{\left(\varepsilon_{Z_{2}}-1\right)}{\left(\varepsilon_{Z_{1}}-1\right)}
\end{aligned}
$$

A relação entre as taxas de juros cobradas pelo monopolista em mercados diferentes é uma função exclusiva das elasticidades-juros das demandas correspondentes.

\section{A.5.4 Demanda por Moeda}

Tome as condições de primeira ordem para moeda (A.20) e ativo risk-free. Suponha que a restrição de pagamentos não é efetiva, isto é $E \lambda_{3, t}=0$, então:

$$
\begin{aligned}
E_{t} \frac{1}{\pi_{t+1}} & =\frac{1}{\Lambda_{t}} \lambda_{1, t} \\
R_{t} & =\frac{1}{\Lambda_{t}} \lambda_{1, t}
\end{aligned}
$$

Ambos são ativos bancários e portanto têm o mesmo custo de captação a valor presente $\lambda_{1, t}$. Todavia o ativo monetário rende $E_{t} \frac{1}{\pi_{t+1}}$ enquanto o ativo livre de risco rende $R_{t}$. A existência de solução interior nesse cenário exige que o retorno da moeda seja pelo menos igual a $R_{t}$. Afora a possibilidade de uma deflação, o retorno da moeda será $\frac{1}{\pi_{t+1}} \leq 1$.

Somente com deflação a moeda poderia ter rentabilidade superior à uma unidade e apenas após um certo nível a moeda seria tão rentável quanto qualquer outro ativo da economia, resultado que é bastante conhecido como Regra de Friedman. Todavia em outras situações de normalidade, a moeda é estritamente dominada em retorno pelos demais ativos financeiros. Isso 
significa no contexto do banco que, na ausência de fricções operacionais, como a necessidade de manter liquidez para pagamentos, a demanda do banco por saldos monetários é zero. Os depósitos bancários e o capital próprio têm solução interior, assim como o mercado de crédito, mas a diferença entre passivos totais e o crédito deve ser alocado em ativos mais rentáveis, sempre que 2.3 vale.

A rentabilidade do ativo monetário não justifica a demanda por moeda, que será determinada estritamente por razões friccionais, sejam de liquidez ou de política monetária impostas pelo governo. A necessidade de liquidez para pagamentos é sempre não nula, por construção, dada a característica do sistema de pagamentos de liquidação bruta:

Para atender a necessidade de pagamentos o banco precisa adquirir instrumentos custosos, como moeda ou remédios de liquidez. De outra forma, o banco não mantém estoques de tais instrumentos. Então, a restrição de liquidez é efetiva. A expectativa do banco ex-ante é que a restrição de liquidez será binding, independente se constituir ou não o estoque em moeda, $E_{t} \lambda_{3, t+1}>0$. Portanto:

$$
E_{t}\left(\frac{m_{t}}{P_{t+1}}+b c_{t+1}+i_{t+1}\right)=E_{t} \mathcal{P}_{t+1}
$$

Duas possibilidades se colocam: 
Caso A Solução interior:

$$
\begin{aligned}
E_{t}\left(b c_{t+1}+i_{t+1}\right) & =0 \\
E_{t} \frac{m_{t}}{P_{t+1}} & =E_{t} \mathcal{P}_{t+1} \\
E_{t} \frac{m_{t}}{P_{t+1}} \frac{P_{t}}{P_{t}} & =E_{t} \mathcal{P}_{t+1} \\
\frac{m_{t}}{P_{t}} E_{t} \frac{P_{t}}{P_{t+1}} & =E_{t} \mathcal{P}_{t+1} \\
\frac{m_{t}}{P_{t}} & =E_{t} \pi_{t+1} \mathcal{P}_{t+1}
\end{aligned}
$$

O banco retém saldos monetários em volume suficiente para atender a expectativa de liquidez requerida no período seguinte.

Caso B Solução de canto $\frac{m_{t}}{P_{t}}=0$. O banco não possui moeda porque escolhe atender a necessidade de liquidez no período seguinte utilizando-se dos instrumentos disponíveis, como o redesconto da autoridade monetária e/ou os empréstimos no mercado interbancário. Então:

$$
E_{t}\left(b c_{t+1}+i_{t+1}\right)=E_{t} \mathcal{P}_{t+1}
$$

Por implicação, sejam as condições de ótimo dos remédios de liquidez, em que pelo menos uma deve ser válida:

$$
\begin{aligned}
R_{t}^{b c}-R_{t} & =\frac{1}{\Lambda_{t}} \lambda_{3, t} \\
\frac{\lambda_{3, t}}{\Lambda_{t}} & =\left(R_{t}^{b c}-R_{t}\right)
\end{aligned}
$$

$\lambda_{3, t}$ é um custo de liquidez para o banco em valores presentes. Representa quanto o banco perde por ter de atender a condição de pagamentos, muito embora possa utilizar o recurso adicional para comprar títulos públicos. A diferença de taxas de juros reflete o custo marginal líquido do instrumento de liquidez para o banco. 
Tome a condição de ótimo para a moeda:

$$
\begin{aligned}
E_{t} \frac{1}{\pi_{t+1}}+E_{t} \frac{1}{\pi_{t+1}} \frac{1}{\Lambda_{t}} \lambda_{3, t+1} & =\frac{1}{\Lambda_{t}} \lambda_{1, t} \\
E_{t} \frac{1}{\pi_{t+1}} \lambda_{3, t+1} \frac{1}{\Lambda_{t}} & =R_{t}-E_{t} \frac{1}{\pi_{t+1}} \\
E_{t} \frac{\lambda_{3, t+1}}{\Lambda_{t}} & =E_{t} \pi_{t+1} R_{t}-1
\end{aligned}
$$

Esse é o custo de oportunidade esperado de utilizar moeda hoje como reserva de liquidez para pagamentos amanhã. O banco será indiferente entre atender a restrição de pagamentos mediante estoque de moeda ou empréstimos de liquidez se, em valores presentes, o custo de oportunidade esperado de uma unidade monetária for equivalente ao resultado líquido obtido se tomar empréstimo de última instância. O empréstimo é utilizado como liquidez adicional no período seguinte, mas pode ser emprestado após a compensação dos pagamentos de tal forma que no período subsequente, em $t+2$, o banco recebe juros de um período e finalmente paga o empréstimo junto à autoridade monetária.

$$
\left(E_{t} R_{t+1}^{b c}-E_{t} R_{t+1}\right) \Lambda_{t+1}=\left(E_{t} \pi_{t+1} R_{t+1}-1\right) \Lambda_{t}
$$

A hipótese (2.5) garante que os juros cobrados pela autoridade monetária serão suficientemente elevados, obviamente acima da taxa bruta de juros livres de risco, tal que o custo marginal de tomar emprestado com a autoridade monetária, mesmo que descontando o rendimento do recurso adicional, é sempre superior ao custo de oportunidade de reter moeda para satisfazer a necessidade de liquidez. Portanto, tomando-se válida (2.5), o banco não se vale da disposição de empréstimo de última instância para expandir sua oferta de crédito. Garante-se solução interior para a moeda. 


\section{A.5.5 Instrumentos de Liquidez}

As condições de ótimo são dadas abaixo:

$$
\begin{aligned}
b c_{t}\left[R_{t}^{b c}-R_{t}-\frac{1}{\Lambda_{t}} \lambda_{3, t}\right] & =0 \\
i_{t}\left[R_{t}^{i}-R_{t}-\frac{1}{\Lambda_{t}} \lambda_{3, t}\right] & =0
\end{aligned}
$$

No mercado interbancário, os juros pagos devem ser iguais aos juros do empréstimo de recursos ao mercado bancário, por simetria. Pela equação (2.50) essa taxa de juros é superior à taxa de juros livre de risco. Todavia, os bancos são iguais e, por simetria, não haverá operações no mercado interbancário (será determinado que $i_{t}=0 \quad \forall t$ ). Por sua vez, a taxa de juros de redesconto é um preço administrado pela autoridade monetária com objetivos de política econômica. Assume-se que essa taxa administrada deva ser consistente com (2.5).

Daí deriva que o único crédito efetivamente disponível em caso de necessidade de liquidez do sistema será o redesconto. Por contradição, se não vale a primeira desigualdade em (2.5) o custo de captação junto ao banco central é inferior ao custo de funding no mercado interbancário e, mesmo com possível assimetria entre os bancos, o mercado interbancário estaria fechado.

Agora analisemos a restrição de liquidez. Em um dado período $t$, o banco traz um estoque de moeda $m_{t}$ escolhido no período anterior e conhece o volume de liquidez para pagamentos em $\mathcal{P}_{t}$. Duas situações serão possíveis:

1. $\quad \frac{m_{t}}{P_{t}} \geq \mathcal{P}_{t}$, a restrição não será binding e $\lambda_{3, t}=0$. Isso pode acontecer porque a necessidade de liquidez para pagamentos mostrou-se inferior àquela esperada pelo banco no período anterior, quando constituiu o estoque real de moeda $\frac{m_{t}}{P_{t}}$. Uma possibilidade é que houve choque negativo na função pagamentos, ou seja, o volume de pagamentos bancários realizado é inferior ao previsto. Outra possibilidade trata do efeito da infla- 
ção sobre os ativos monetários do banco: se a inflação é menor do que a esperada, o valor do estoque de moeda constituído é mais do que suficiente para desempenhar os pagamentos bancários. Como os instrumentos de liquidez são custosos ao banco, que só os demanda por obrigação operacional, então, $b c_{t}=i_{t}=0$.

2. $\frac{m_{t}}{P_{t}}<\mathcal{P}_{t}$, a restrição de liquidez é efetiva e $\lambda_{3, t}>0$. A demanda pelos remédios de liquidez será $b c_{t}+i_{t}=\mathcal{P}_{t}-\frac{m_{t-1}}{P_{t}}$. Então, o banco utiliza o empréstimo que possuir a menor taxa.

\section{A.5.6 Demanda de Depósitos Bancários}

Como posto anteriormente, a hipótese 2.1 associada à característica da tecnologia bancária de complementaridade dos fatores depósitos de terceiros e capital próprio, os depósitos bancários devem ter solução interior.

Tome a condição de ótimo:

$$
\left(R^{d}+\mathcal{C}_{d}\right)-\frac{1}{\Lambda} \lambda_{2} z_{\mathcal{T}} \mathcal{T}_{d}+E \frac{1}{\Lambda} \lambda_{3}^{\prime} \mathcal{P}^{\prime}{ }_{d}=\frac{1}{\Lambda} \lambda_{1}
$$

Chamando a condição de ótimo para a moeda com solução interior:

$$
\left(R^{d}+\mathcal{C}_{d}\right)-\frac{1}{\Lambda} \lambda_{2} z_{\mathcal{T}} \mathcal{T}_{d}+\left(R-E \frac{1}{\pi^{\prime}}\right) \mathcal{P}^{\prime}{ }_{d}=R
$$

A condição de ótimo para os títulos públicos quando associada à condição dos juros do crédito permite conhecer $\lambda_{2}$ e simplificar a condição de ótimo:

$$
R^{d}+\mathcal{C}_{d}+\left(R-E \frac{1}{\pi^{\prime}}\right) \mathcal{P}^{\prime}{ }_{d}=R+\frac{1}{\Lambda} \lambda_{2} z_{\mathcal{T}} \mathcal{T}_{d}
$$

A condição de ótimo para os depósitos bancários determina que o banco demande até o ponto em que o benefício marginal da captação de recursos de terceiros seja igual ao custo marginal 
de reter depósitos bancários. O custo marginal pode ser decomposto em pagamento de juros ao depositante, custos operacionais e custo de oportunidade da moeda pela retenção maior de saldos monetários, uma vez que há expectativa de maior necessidade de liquidez para pagamentos.

O depósito bancário adicional expande o ativo bancário em uma unidade, que se subdivide em dois estoques: uma fração amplia a oferta de crédito e a outra fração aumenta a reserva de liquidez. O benefício marginal é a remuneração pela taxa de juros do título público do ativo bancário adicional mais o spread dos juros privados sobre os juros do título público que corre sobre o crédito marginal. Obviamente, se a demanda agregada já for atendida no nível de juros sobre depósitos, o banco constitui todo o ativo marginal em títulos públicos. $\lambda_{2}$ informa precisamente o preço em termos de spread de juros que o banco percebe se houver demanda o crédito marginal permitido pela sua tecnologia.

A tecnologia do banco é uma equação do sistema que relaciona depósitos totais, capital próprio e demanda agregada de crédito:

$$
\lambda_{2}\left[z_{\mathcal{T}} \mathcal{T}(d, \mathcal{K})-l_{b}\right]=0
$$

\section{A.5.7 Agregação}

Os bancos são idênticos e uniformemente distribuídos no intervalo [0,1]. Como não há rigidez de preços, as firmas bancárias ofertam a taxas de juros iguais em cada setor. A determinação do custo marginal real e das elasticidades-juros das demandas em cada mercado é suficiente para conhecer as taxas cobradas pelos bancos em competição monopolística. Em não havendo dispersão de preços, a oferta unitária é igual à oferta da indústria em cada mercado e também no agregado. 
O mercado interbancário não é efetivo, pois os bancos são iguais. A oferta de crédito e a demanda por instrumentos de liquidez são nulas $L_{t}^{(x)}=I_{t}=0$. Dessa forma, os bancos dispõem de um único instrumento de liquidez - o empréstimo de última instância com a autoridade monetária - após um choque não antecipado no volume de pagamentos.

Pela definição do lucro em um dado mercado de crédito:

$$
\begin{aligned}
\int_{0}^{1} \Pi_{b j}^{\prime} d j & =\int_{0}^{1} l_{j}^{d}\left(\frac{R_{b j}^{l}}{R_{j}^{l}}\right)^{-\theta_{j}} R_{b j}^{l} d j \\
\Pi_{b, t+1}^{(j)} & =\int_{0}^{1} l_{j}^{d} \frac{\theta_{j}}{\theta_{x}} \frac{\left(\theta_{x}-1\right)}{\left(\theta_{j}-1\right)} R_{x, t}^{l} d j \\
\Pi_{b, t+1}^{(j)} & =\frac{\theta_{j}}{\theta_{x}} \frac{\left(\theta_{x}-1\right)}{\left(\theta_{j}-1\right)} R_{x, t}^{l} L_{t}^{d(j)}
\end{aligned}
$$

Assim:

$$
\begin{aligned}
\Pi_{b, t+1}^{(e)} & =\frac{\theta_{e}}{\theta_{x}} \frac{\left(\theta_{x}-1\right)}{\left(\theta_{e}-1\right)} R_{x, t}^{l} L_{t}^{d(e)} \\
\Pi_{b, t+1}^{(i)} & =\frac{\theta_{i}}{\theta_{x}} \frac{\left(\theta_{x}-1\right)}{\left(\theta_{i}-1\right)} R_{x, t}^{l} L_{t}^{d(i)} \\
\Pi_{b, t+1}^{(x)} & =R_{x, t}^{l} L_{t}^{d(x)}
\end{aligned}
$$

O lucro de cada banco e da indústria bancária, por agregação, é dado por:

$$
\begin{aligned}
\Pi_{t+1}= & R_{x, t}^{l}\left[\frac{\theta_{j}}{\theta_{x}} \frac{\left(\theta_{x}-1\right)}{\left(\theta_{j}-1\right)} L_{t}^{d(j)}+\frac{\theta_{e}}{\theta_{x}} \frac{\left(\theta_{x}-1\right)}{\left(\theta_{e}-1\right)} L_{t}^{d(e)}+\frac{\theta_{i}}{\theta_{x}} \frac{\left(\theta_{x}-1\right)}{\left(\theta_{i}-1\right)} L_{t}^{d(i)}+L_{t}^{d(x)}\right]+R_{t}^{b} B_{t}+\frac{M_{t}}{P_{t}} \frac{1}{\pi_{t+1}} \\
& -\left[R_{t}^{d} D_{t}+R_{t}^{b c} B C_{t}+R_{t}^{i} I_{t}+\mathcal{C}\left(d_{t}, l_{t}\right)\right]
\end{aligned}
$$

Títulos públicos, moeda, depósitos bancários, redesconto, crédito interbancário e cotas de patrimônio têm agregação trivial. A nomeação maiúscula substitui o equivalente minúsculo indicando agregação. 
As transferências $V_{t}^{\text {ban }}$ para as famílias são do tipo lump-sum.

$$
V_{t+1}^{b a n}=\omega \mathcal{K}_{t}+\Theta_{t} \Pi_{t}^{b a n}
$$

\section{A.6 Equilíbrio Geral Competitivo}

As equações que definem o equilíbrio geral competitivo da economia são listadas a seguir:

\section{Famílias}

(A.33)

$$
\frac{1}{\tilde{C}_{t}}=\frac{1}{\left(C_{t}-b C_{t-1}\right)}-\beta b \frac{1}{\left(C_{t+1}-b C_{t}\right)}
$$

$$
Z^{f a m}=\frac{\theta_{j}}{\theta_{x}} \frac{\left(\theta_{x}-1\right)}{\left(\theta_{j}-1\right)} R^{l(x)}
$$

$$
(\mathrm{A} .35) C_{t}+\frac{M_{t}}{P_{t}}+D_{t}+B_{t}+A_{t}+Z_{t-1}^{f a m} \bar{L}^{(j)}=\left(1-\tau_{t}^{h}\right) W_{t} H_{t}+\bar{L}^{(j)}+\frac{M_{t-1}}{P_{t}}
$$$$
+R_{t-1}^{b} B_{t-1}+R_{t-1}^{d} D_{t-1}+R_{t-1} A_{t-1}
$$$$
+V_{t}^{b a n}+V_{t}^{e m p}+V_{t}^{f i r}+T_{t}
$$

$$
\begin{aligned}
\left(1-H_{t}\right) W_{t}\left(1-\tau_{t}^{h}\right) & =\varsigma_{1} \tilde{C}_{t} \\
\frac{M_{t}^{f a m}}{P_{t}}\left[\frac{\left.R_{t}-E_{t} \frac{1}{\pi_{t+1}}\right]}{R_{t}}\right] & =\varsigma_{2} \tilde{C}_{t} \\
D_{t}\left[\frac{R_{t}-R_{t}^{d}}{R_{t}}\right] & =\varsigma_{3} \tilde{C}_{t} \\
B_{t}^{\text {fam }}\left[\frac{R_{t}-R_{t}^{b}}{R_{t}}\right] & =\varsigma_{4} \tilde{C}_{t}
\end{aligned}
$$


Firmas

(A.40)

$$
\left(R_{t}^{k}-1\right)=\Omega_{t} z_{t} \alpha A\left(\frac{K_{t}}{H_{t}}\right)^{\alpha-1}
$$

$$
W_{t}=\Omega_{t} z_{t}(1-\alpha) A \frac{\left(\frac{K_{t}}{H_{t}}\right)^{\alpha}}{1+\nu\left[\frac{\theta_{i}}{\theta_{x}} \frac{\left(\theta_{x}-1\right)}{\left(\theta_{i}-1\right)} R_{x, t+1}^{l}-1\right]}
$$

$$
L_{t}^{(i)}=\nu W_{t} H_{t}
$$

$$
\eta x_{t}^{1}=(\eta-1) x_{t}^{2}
$$

$$
x_{t}^{1}=Y_{t} \Omega_{t} \tilde{p}_{t}^{-\eta-1}+\alpha_{f} E_{t} \frac{\pi_{t+1}}{R_{t+1}}\left(\frac{\tilde{p}_{t}}{\tilde{p}_{t+1}}\right)^{-\eta-1}\left(\frac{\pi_{t}^{\chi_{f}}}{\pi_{t+1}}\right)^{-\eta} x_{t+1}^{1}
$$

$$
x_{t}^{2}=Y_{t} \tilde{p}_{t}^{-\eta}+\alpha_{f} E_{t} \frac{\pi_{t+1}}{R_{t+1}}\left(\frac{\tilde{p}_{t}}{\tilde{p}_{t+1}}\right)^{-\eta}\left(\frac{\pi_{t}^{\chi_{f}}}{\pi_{t+1}}\right)^{1-\eta} x_{t+1}^{2}
$$

$$
1=\alpha_{f} \pi_{t}^{\eta-1} \pi_{t-1}^{\chi_{f}(1-\eta)}+\left(1-\alpha_{f}\right) \tilde{p}_{t}^{1-\eta}
$$

(A.47)

$$
Y_{t} s_{t}=z_{t} A K_{t}^{\alpha} H_{t}^{1-\alpha}-\psi
$$

(A.48) $\quad \ln z_{t}=\rho_{(z)} \ln z_{t-1}+\epsilon_{t}^{z}$

(A.49)

$$
s_{t}=\left(1-\alpha_{f}\right) \tilde{p}_{t}^{-\eta}+\alpha_{f}\left(\frac{\pi_{t}}{\pi_{t-1}^{\chi_{f}}}\right)^{\eta} s_{t-1}
$$

(A.50)

(A.51)

$$
\Pi_{t}^{f i r}=Y_{t} s_{t}\left[\alpha_{f} \pi_{t-1}^{\chi_{f}-1}+\left(1-\alpha_{f}\right) \tilde{p}_{t}\right]
$$

$$
-\left(R_{t}^{k}-1\right) K_{t}^{d}-W_{t} H_{t}^{d}-\left(\frac{\theta_{i}}{\theta_{x}} \frac{\left(\theta_{x}-1\right)}{\left(\theta_{i}-1\right)} R_{x, t+1}^{l}-1\right) L_{t}^{(i)}
$$

(A.52) $\quad V_{t}^{\text {fir }}=(1-\iota)\left(1-\tau_{t}^{\Pi^{f i r}}\right) \Pi_{t}^{\text {fir }}$ 


\section{Produtores de Capital}

(A.53)

$$
\begin{aligned}
1= & Q_{t}\left[1-\frac{\varpi}{2}\left(\frac{I_{t}}{I_{t-1}}-1\right)^{2}-\varpi \frac{I_{t}}{I_{t-1}}\left(\frac{I_{t}}{I_{t-1}}-1\right)\right] \\
& +E_{t} \frac{Q_{t+1}}{R_{t+1}}\left(\frac{I_{t+1}}{I_{t}}\right)^{2} \varpi\left(\frac{I_{t+1}}{I_{t}}-1\right) \\
K_{t+1}= & (1-\delta) K_{t}+I_{t}\left[1-\mathcal{S}\left(\frac{I_{t}}{I_{t-1}}\right)\right]
\end{aligned}
$$

(A.54)

\section{Empreendedores}

$$
\begin{aligned}
\Phi(\bar{\kappa}) & =\mathcal{N}\left(\frac{\ln \bar{\kappa}-1}{\sigma_{\Phi}}\right) \\
\bar{\kappa} h(\bar{\kappa}) & =\frac{1}{\sigma_{\Phi} \sqrt{2 \pi}} \frac{e^{-\left(\frac{\ln \bar{\kappa}-\mu_{\Phi}}{\sigma_{\Phi}}\right)^{2} / 2}}{1-\mathcal{N}\left(\frac{\ln \bar{\kappa}-\mu_{\Phi}}{\sigma_{\Phi}}\right)} \\
\mathcal{H}(\bar{\kappa}) & =1-e^{1+\frac{1}{2} \sigma_{\Phi}^{2}} \mathcal{N}\left(\frac{1+\sigma_{\Phi}^{2}-\ln \bar{\kappa}}{\sigma_{\Phi}}\right) \\
J_{t} & =\left[\left(1-\tau_{t}^{k}\right)\left(R_{t}^{k}-1\right)+(1-\delta)\right]
\end{aligned}
$$

(A.55) $\quad N_{t}=(1-\gamma) Q_{t} J_{t-1} K_{t-1}\left\{1-\mathcal{H}\left(\bar{\kappa}_{t-1}\right)-\bar{\kappa}_{t-1}\left[1-\Phi\left(\bar{\kappa}_{t-1}\right)\right]\right\}+F_{t}$

(A.56) $v(\bar{\kappa})=(1-\gamma)\{[1-\Phi(\bar{\kappa})] \bar{\kappa}+(1-\mu) \mathcal{H}(\bar{\kappa})\} \frac{E_{t} Q_{t+1} J_{t}}{Z_{t}}$

(A.57) $\quad L_{t}=v(\bar{\kappa}) K_{t}$

(A.58) $Q_{t} K_{t}=N_{t}+L_{t}$

(A.59) $\quad V_{t}^{e m p}=\gamma Q_{t} J_{t-1} K_{t-1}$ 


\section{Bancos}

(A.60)

$$
R_{t}^{l(j)}=\frac{\theta_{j}}{\theta_{x}} \frac{\left(\theta_{x}-1\right)}{\left(\theta_{j}-1\right)} R_{t}^{l(x)}
$$

(A.61)

$$
\frac{R_{t}^{l(e)}}{s(\bar{\kappa})}=\frac{\theta_{e}}{\theta_{x}} \frac{\left(\theta_{x}-1\right)}{\left(\theta_{e}-1\right)} R_{t}^{l(x)}
$$

$$
R_{t}^{l(i)}=\frac{\theta_{i}}{\theta_{x}} \frac{\left(\theta_{x}-1\right)}{\left(\theta_{i}-1\right)} R_{t}^{l(x)}
$$

$$
\Sigma_{t}=R_{t}^{l(x)}\left(1-\frac{1}{\theta_{x}}\right)
$$

(A.64)

$$
\frac{M_{t}^{\text {ban }}}{P_{t}}=E_{t} \pi_{t+1} \mathcal{P}_{t+1}
$$

$$
B_{t}^{b a n}=D_{t}+B C_{t}+\mathcal{K}_{t}-L_{t}-\frac{M_{t}^{b a n}}{P_{t}}
$$

$$
L_{t}=L_{t}^{(j)}+L_{t}^{(e)}+L_{t}^{(i)}
$$

(A.67) $\begin{aligned} R_{t}= & R_{t}^{d}+\left[\nu_{1} \frac{1}{D_{t}}-\nu_{3} \frac{1}{L_{t} D_{t}}\right]+\left(R_{t}-E_{t} \frac{1}{\pi_{t+1}}\right) z_{\mathcal{P} t+1} \eta_{1} \frac{1}{\left(D_{t+1}+1\right)} \\ & -\left\{\frac{\lambda_{2, t}}{\Lambda} \frac{\alpha_{b}}{D_{t+1}}\left[A_{b a n}\left(D_{t+1}\right)^{\alpha_{b}}\left(\mathcal{K}_{t}\right)^{\beta_{b}}\right]\right\}\end{aligned}$

(A.68) $\quad 0=\lambda_{2, t}\left[z_{\mathcal{T} t} A_{b a n}\left(D_{t+1}\right)^{\alpha_{b}}\left(\mathcal{K}_{t}\right)^{\beta_{b}}-L_{t}\right]$

(A.69) $\quad \Lambda_{t}=\frac{1}{R_{t}}+\Theta E_{t} \mathfrak{V}_{\mathcal{K}_{t+1}}$

(A.70) $\quad \mathfrak{V}_{\mathcal{K}_{t}}=-\frac{1}{R_{t}}+R_{t}+\frac{\lambda_{2, t}}{\Lambda} z_{\mathcal{T}} \mathcal{T}_{\mathcal{K}}+(1-\omega) E_{t} \mathfrak{V}_{\mathcal{K}_{t+1}}$

(A.71)

(A.72)

(A.77)

$$
\begin{aligned}
0 & =\Delta_{t}\left[-\Lambda_{t}+E \mathfrak{V}_{\mathcal{K}^{\prime}}\right] \\
\Sigma_{t} & =R_{t}+\left[\nu_{2} \frac{1}{L_{t}}-\nu_{3} \frac{L_{t} D_{t}}{]}+\frac{\lambda_{2, t}}{\Lambda_{t}}\right. \\
B C_{t} & =\max \left(0, \mathcal{P}_{t}-\frac{M_{t}^{\text {ban }}}{P_{t-1}} \frac{1}{\pi_{t}}\right) \\
\mathcal{K}_{t} & =(1-\omega) \mathcal{K}_{t-1}+\Delta_{t}+\Theta_{t} \Pi_{t} \\
\mathcal{P}_{t} & =z_{\mathcal{P} t} \eta_{1} \ln \left(D_{t}+1\right) \\
\ln z_{\mathcal{P} t} & =\rho_{\mathcal{P}} \ln z_{\mathcal{P} t-1}+\varepsilon_{\mathcal{P} t} \\
\ln z_{\mathcal{T} t} & =\rho_{z_{\mathcal{T}}} \ln z_{\mathcal{T} t-1}+\epsilon^{z_{\mathcal{T} t}}
\end{aligned}
$$


(A.78) $\quad \Pi_{t}^{\text {ban }}=R_{x, t}^{l}\left[\frac{\theta_{j}}{\theta_{x}} \frac{\left(\theta_{x}-1\right)}{\left(\theta_{j}-1\right)} L_{t-1}^{d(j)}+\frac{\theta_{e}}{\theta_{x}} \frac{\left(\theta_{x}-1\right)}{\left(\theta_{e}-1\right)} L_{t-1}^{d(e)}+\frac{\theta_{i}}{\theta_{x}} \frac{\left(\theta_{x}-1\right)}{\left(\theta_{i}-1\right)} L_{t-1}^{d(i)}\right]$ $+R_{t}^{b} B_{t}+\frac{M_{t}}{P_{t-1}} \frac{1}{\pi_{t}}-R_{t}^{d} D_{t}-\mathcal{K}_{t}-\Delta_{t}-R_{t}^{b c} B C_{t}$ $-\left[\overline{\mathcal{C}}+\nu_{1} \ln \left(D_{t}+1\right)+\nu_{2} \ln \left(L_{t}+1\right)-\nu_{3} \ln \left(D_{t} L_{t}+1\right)\right]$

(A.79) $\quad V_{t}^{\text {ban }}=\omega \mathcal{K}_{t-1}+\Theta_{t} \Pi_{t}^{\text {ban }}$

\section{Governo}

(A.80)

$$
\tau_{t}=\tau_{t}^{k} R_{t}^{k} K_{t}+\tau_{t}^{h} W_{t} H_{t}+\tau_{t}^{\Pi^{f i r}} \Pi_{t}^{f i r}+\tau_{t}^{\Pi^{b a n}} \Pi_{t}^{b a n}
$$

(A.81) $B_{t}+\frac{M_{t}}{P_{t}}=G_{t}+T_{t}+\frac{M_{t-1}}{P_{t-1}} \frac{1}{\pi_{t}}+B C_{t+1}^{s}+R_{t}^{b} B_{t}-\left(\tau_{t}+R_{t}^{b c} B C_{t}^{s}\right)$

(A.82) $\left.\quad R_{t}^{b}=\rho R_{t-1}^{b}+(1-\rho)\left[\bar{R}^{b}+\mu_{\pi}\left(E_{t} \pi_{t+1}-\bar{\pi}\right)+\mu_{y}\left(Y_{t}-\bar{Y}\right)\right]\right)+\epsilon_{t}$

(A.83) $\ln \left(\frac{G_{t}}{\bar{G}}\right)=\rho_{G} \ln \left(\frac{G_{t-1}}{\bar{G}}\right)+\epsilon_{t}^{G}$

(A.84) $\ln \left(\frac{T_{t}}{\bar{T}}\right)=\rho_{T} \ln \left(\frac{T_{t-1}}{\bar{T}}\right)+\epsilon_{t}^{t}$

\section{Market Clearing}

(A.85)

$$
\begin{aligned}
Y_{t} & =C_{t}+I_{t}+G_{t} \\
\frac{M_{t+1}}{P_{t}} & =\frac{M_{t+1}^{f a m}}{P_{t}}+\frac{M_{t+1}^{\text {ban }}}{P_{t}}
\end{aligned}
$$

(A.86)

(A.87)

$$
B_{t}=B_{t}^{f a m}+B_{t}^{b a n}
$$




\section{Apêndice B}

\section{SOLUÇÃO DO MODELO DSGE}

Este apêndice contém os procedimentos e os resultados da solução de expectativas racionais do modelo DSGE proposto no capítulo 2.

\section{B.1 Steady State}

A seguir, descreve-se brevemente os procedimentos para obter a solução do estado estacionário.

Com a taxa bruta de inflação $\pi$ calibrada é possível conhecer $\tilde{p}, s$. A equação de determinação de preços da firma permite conhecer o custo marginal do bem final, $\Omega$. O lucro da firma é dado por:

$$
\Pi^{f i r}=Y\left(s\left[\alpha_{f} \pi^{\chi_{f}-1}+\left(1-\alpha_{f}\right) \tilde{p}\right]-\Omega A\right)-\Omega A \psi
$$

onde $\psi$ é o custo fixo. Como a razão lucro produto é calibrada, $\frac{\psi}{Y}$ é conhecido.

Por sua vez, a taxa livre de risco é igual $R=1 / \beta$ pela equação de Euler para as famílias. $J$ é o retorno bruto do capital livre de impostos e depreciação (alíquotas e taxa conhecidas). A calibração de 200 pontos base torna conhecida o retorno bruto do capital $R^{k}$. 
Agora tome a relação de market-clearing do mercado de bens finais.

$$
\frac{C}{Y}+\frac{I}{Y}+\frac{G}{Y}=1
$$

Levando em conta que o investimento de estado estacionário é a depreciação do capital $I=\delta K$, que advém da lei de movimento do capital, mais a equação de demanda por capital das firmas, é possível escrever o retorno bruto do capital como:

$$
R^{k}-1=\frac{\delta}{\bar{i}} \Omega \alpha A\left(s+\frac{\psi}{Y}\right)
$$

Daí, obtém-se $\bar{i}$ a taxa de investimento em estado estacionário. A razão gastos do governo e produto é calibrada, portanto também se conhece a razão do produto que é consumida.

Pela função de produção da firma, é possível escrever:

$$
\frac{Y s+\psi}{K}=\frac{1}{A}\left(\frac{Y s+\psi}{H}\right)^{-(1-\alpha) / \alpha}
$$

Retomando a equação do retorno bruto do capital, que é igual à forma da equação de demanda por capital das firmas, é possível determinar o produto de estado estacionário, pois $H$ é calibrado:

$$
Y\left(s+\frac{\psi}{Y}\right)=\left[\frac{\delta}{\bar{i}}\left(s+\frac{\psi}{Y}\right)\right]^{-\alpha /(1-\alpha)} A^{1 /(1-\alpha)} H
$$

Então também se determina $C, I, G$ e $K$. O salário real $W$ é definido pela equação de oferta de trabalho das famílias.

Se a renda do trabalho é conhecida, também se sabe qual a demanda de crédito das firmas para antecipar a renda do trabalho, $L^{(i)}$. A demanda por trabalho permite descobrir a taxa de juros 
no crédito às firmas:

$$
Z^{f i r}=1+\frac{1}{\nu}\left[\Omega(1-\alpha) A \frac{(Y s+\psi)}{W H}-1\right]
$$

$Q=R$ em estado estacionário, pela condição de ótimo dos produtores de capital. Uma vez que $K$ é conhecido e a razão capital e riqueza dos empreendedores é calibrada, define-se $N^{e}$ e $L^{e}$, a demanda por crédito dos empreendedores. $F^{\text {fir }}$ é a fração do lucro das firmas que é transferida para investimento. Então é possível conhecer o nível crítico de solvência pela equação não linear:

$$
N^{e}=(1-\gamma) Q\left[\left(1-\tau^{k}\right)\left(R^{k}-1\right)+(1-\delta)\right] K\{1-\mathcal{H}(\bar{\kappa})-\bar{\kappa}[1-\Phi(\bar{\kappa})]\}+F^{\text {fir }}
$$

$\kappa$ define outras variáveis do acelerador, $\tilde{s}, v$ e também permite obter $Z^{e m p}$, a taxa bruta de juros que ancora o contrato financeiro.

No lado da família, a moeda $M^{\text {fam }}$ é diretamente obtida pela equação de ótimo. O crédito tomado pelas famílias é calibrado como fração do crédito total, que, por sua vez, é a soma dos créditos para famílias, firmas e empreendedores. Logo, $L$ é conhecido.

Em equilíbrio estacionário, a taxa de juros do governo é igual à taxa livre de risco $R b=R$. As equações de ótimo do banco permitem conhecer o volume de depósitos $D$, o capital próprio do banco $\mathcal{K}$, moeda e títulos públicos mantidos pelo banco. A taxa de juros que remunera os depósitos bancários vem da equação de ótimo da família. O custo marginal do banco $\Sigma$ também é definido pelo bloco de equações.

A razão dívida pública e produto define $B$ total e a quantidade de títulos comprada pelas famílias. A arrecadação do governo é conhecida, porque as alíquotas são dadas e as variáveis reais são conhecidas. A restrição orçamentária do governo em estado estacionário determina o 
volume de transferências $T$ :

$$
G+T+\frac{M}{P}\left(\frac{1}{\pi}-1\right)+\left(R^{b}-1\right) B=\tau
$$

Por sua vez, a restrição orçamentária da família é equilibrada por uma taxa de juros $Z^{\text {fam }}$ sobre o crédito tomado junto aos bancos. Finalmente, as variáveis que explicam o lucro do banco são todas conhecidas e a condição de lucro zero no mercado extrai o valor do custo fixo de produção como fechamento. As elasticidades-juros das demandas por crédito são obtidas em resíduo, uma vez que as taxas de juros de estado estacionário são já conhecidas pelos blocos de equações relacionados a cada mercado demandante e o custo marginal do crédito é determinado nas condições de oferta do banco.

\section{B.2 Resultados de Steady State}

Tabela B.1: Todos os Resultados de Estado Estacionário

\begin{tabular}{llll}
\hline Variável & Valor & Variável & Valor \\
\hline$C$ & 0.7001 & $V^{\text {ban }}$ & 0.0032 \\
$H$ & 0.3500 & $F^{\text {fir }}$ & 0.0173 \\
$M^{\text {fam }}$ & 0.5532 & $\mathbb{T}$ & 0.2785 \\
$M^{\text {ban }}$ & 0.2765 & $G$ & 0.2254 \\
$M^{\text {fam }}$ & 0.8296 & $T$ & 0.0538 \\
$B^{\text {ban }}$ & 0.7207 & déficit & 0.0007 \\
$B$ & 0.0681 & $\theta^{E}$ & 31.9577 \\
$D^{\text {E }}$ & 0.7889 & $\theta^{I}$ & 1.8528 \\
$\tilde{C}$ & 0.7285 & $\theta^{J}$ & 0.9075 \\
& 0.6877 & $\bar{C}$ & -0.0004 \\
& $($ continua $)$ & &
\end{tabular}


Tabela B.1: (continuação)

\begin{tabular}{|c|c|c|c|}
\hline Variável & Valor & Variável & Valor \\
\hline$Y$ & 1.1269 & $R^{B C}$ & 1.4000 \\
\hline$W$ & 1.1336 & $R$ & 1.0099 \\
\hline$\pi$ & 1.0103 & $R^{d}$ & 1.0089 \\
\hline$x^{1}$ & 2.3113 & $R^{b}$ & 1.0099 \\
\hline$x^{2}$ & 2.7736 & $R^{k}$ & 1.0299 \\
\hline$\Omega$ & 0.8322 & $R^{l(x)}$ & 1.0454 \\
\hline$\tilde{p}$ & 1.0166 & $Z^{f a m}$ & -10.0522 \\
\hline$s$ & 1.0014 & $Z^{f i r}$ & 2.2259 \\
\hline$\Pi^{f i r}$ & 0.1361 & $Z^{e m p}$ & 1.0576 \\
\hline$\tilde{Y}$ & 1.1933 & $\Sigma$ & 1.0245 \\
\hline$\psi$ & 0.0648 & $\Lambda$ & 1.0162 \\
\hline$Q$ & 0.9995 & $\lambda 2$ & 0.0112 \\
\hline$J$ & 1.0006 & $V^{k}$ & 1.0162 \\
\hline$K$ & 11.6421 & $\tau^{h}$ & 0.3000 \\
\hline$I$ & 0.2014 & $\tau^{\Pi^{f i r}}$ & 0.1500 \\
\hline$\kappa$ & 0.0202 & $\tau^{k}$ & 0.4000 \\
\hline $\mathcal{H}$ & 0.0000 & $\tau^{\Pi^{b a n}}$ & 0.1500 \\
\hline$\Phi$ & 0.0000 & $z$ & 1.0000 \\
\hline$\kappa h(\kappa)$ & 0.0000 & $z_{\mathcal{T}}$ & 1.0000 \\
\hline$v$ & 0.0191 & $z^{\mathcal{P}}$ & 1.0000 \\
\hline$\tilde{s}$ & 1.0010 & Charter Value & 0.0000 \\
\hline$N^{e}$ & $\begin{array}{r}11.4138 \\
\text { (continua) }\end{array}$ & Lucro Banco/ L & 0.0000 \\
\hline
\end{tabular}


Tabela B.1: (continuação)

\begin{tabular}{lllr}
\hline Variável & Valor & Variável & Valor \\
\hline$L^{j}$ & 0.0224 & Lucro Firma/ Y & 0.1207 \\
$L^{i}$ & 0.2029 & Alavancagem & 0.6149 \\
$L^{e}$ & 0.2227 & Exposição (1) & 0.9192 \\
$L$ & 0.4480 & Exposição (2) & 11.3735 \\
$\mathcal{P}$ & 0.2736 & Spread Captação & 1.0009 \\
$B C$ & 0.0000 & Spread Oferta & 1.0145 \\
$\mathcal{K}$ & 0.0641 & Spread Total & 1.0155 \\
$\Delta$ & 0.0032 & Mark-up Médio & 1.0066 \\
$\Pi^{\text {ban }}$ & 0.0000 & Lastro & 0.1430 \\
$V^{\text {emp }}$ & 0.0116 & Utilidade Esperada & -178.277 \\
$V^{\text {fir }}$ & & & \\
\hline
\end{tabular}

\section{B.3 Momentos Teóricos}

Tabela B.2: Momentos teóricos

\begin{tabular}{lrrr}
\hline Variável & Média & Desvio-padrão & Variância \\
\hline$C$ & 0.7001 & 0.0057 & 0.0000 \\
$H$ & 0.3500 & 0.0055 & 0.0000 \\
$M^{f a m}$ & 0.5532 & 0.1227 & 0.0150 \\
$M^{\text {ban }}$ & 0.2765 & 0.0373 & 0.0014 \\
$M^{\text {fan }}$ & 0.8296 & 0.1357 & 0.0184 \\
& (continua) & & \\
\hline
\end{tabular}


Tabela B.2: (continuação)

\begin{tabular}{|c|c|c|c|}
\hline Variável & Média & Desvio-padrão & Variância \\
\hline$B^{\text {fam }}$ & 0.7207 & 0.1484 & 0.0220 \\
\hline$B^{b a n}$ & 0.0681 & 0.0292 & 0.0008 \\
\hline$B$ & 0.7889 & 0.1305 & 0.0170 \\
\hline$D$ & 0.7285 & 0.1265 & 0.0160 \\
\hline$\tilde{C}$ & 0.6877 & 0.0100 & 0.0001 \\
\hline$Y$ & 1.1269 & 0.0086 & 0.0001 \\
\hline$W$ & 1.1335 & 0.0128 & 0.0002 \\
\hline$\pi$ & 1.0103 & 0.0087 & 0.0001 \\
\hline$x^{1}$ & 2.3113 & 0.1300 & 0.0169 \\
\hline$x^{2}$ & 2.7736 & 0.1560 & 0.0243 \\
\hline$\Omega$ & 0.8322 & 0.0124 & 0.0002 \\
\hline$\tilde{p}$ & 1.0166 & 0.0150 & 0.0002 \\
\hline$s$ & 1.0014 & 0.0015 & 0.0000 \\
\hline$\Pi^{f i r}$ & 0.1361 & 0.0114 & 0.0001 \\
\hline$\tilde{Y}$ & 1.1933 & 0.0089 & 0.0001 \\
\hline$\psi$ & 0.0648 & 0.0000 & 0.0000 \\
\hline$Q$ & 0.9995 & 3.9031 & 15.2345 \\
\hline$J$ & 1.0006 & 0.0004 & 0.0000 \\
\hline$K$ & 11.6421 & 0.0214 & 0.0005 \\
\hline$I$ & 0.2014 & 0.0058 & 0.0000 \\
\hline$\kappa$ & 0.0202 & 0.0793 & 0.0063 \\
\hline $\mathcal{H}$ & $\begin{array}{r}0.0000 \\
\text { (continua) }\end{array}$ & 0.0000 & 0.0000 \\
\hline
\end{tabular}


Tabela B.2: (continuação)

\begin{tabular}{|c|c|c|c|}
\hline Variável & Média & Desvio-padrão & Variância \\
\hline$\Phi$ & 0.0000 & 0.0000 & 0.0000 \\
\hline$\kappa h(\kappa)$ & 0.0000 & 0.0000 & 0.0000 \\
\hline$v$ & 0.0191 & 0.0050 & 0.0000 \\
\hline$\tilde{s}$ & 1.0010 & 0.0000 & 0.0000 \\
\hline$N^{e}$ & 11.4138 & 45.4269 & 2063.6022 \\
\hline$L^{j}$ & 0.0224 & 0.0000 & 0.0000 \\
\hline$L^{i}$ & 0.2029 & 0.0038 & 0.0000 \\
\hline$L^{e}$ & 0.2227 & 0.0586 & 0.0034 \\
\hline$L$ & 0.4480 & 0.0586 & 0.0034 \\
\hline $\mathcal{P}$ & 0.2736 & 0.0366 & 0.0013 \\
\hline$B C$ & 0.0000 & 0.0024 & 0.0000 \\
\hline $\mathcal{K}$ & 0.0641 & 0.0088 & 0.0001 \\
\hline$\Delta$ & 0.0032 & 0.0071 & 0.0001 \\
\hline$\Pi^{b a n}$ & 0.0000 & 0.0172 & 0.0003 \\
\hline$V^{e m p}$ & 0.0116 & 0.0455 & 0.0021 \\
\hline$V^{f i r}$ & 0.0983 & 0.0083 & 0.0001 \\
\hline$V^{b a n}$ & 0.0032 & 0.0143 & 0.0002 \\
\hline$F^{f i r}$ & 0.0173 & 0.0015 & 0.0000 \\
\hline $\mathbb{T}$ & 0.2785 & 0.0043 & 0.0000 \\
\hline$G$ & 0.2254 & 0.0046 & 0.0000 \\
\hline$T$ & 0.0538 & 0.0014 & 0.0000 \\
\hline deficit & $\begin{array}{r}0.0007 \\
\text { (continua) }\end{array}$ & 0.0047 & 0.0000 \\
\hline
\end{tabular}


Tabela B.2: (continuação)

\begin{tabular}{|c|c|c|c|}
\hline Variável & Média & Desvio-padrão & Variância \\
\hline$\theta^{E}$ & 31.9577 & 0.2051 & 0.0421 \\
\hline$\theta^{I}$ & 1.8528 & 0.0119 & 0.0001 \\
\hline$\theta^{J}$ & 0.9075 & 0.0058 & 0.0000 \\
\hline $\bar{C}$ & -0.0004 & 0.0000 & 0.0000 \\
\hline$R^{B C}$ & 1.4000 & 0.0000 & 0.0000 \\
\hline$R$ & 1.0099 & 0.0024 & 0.0000 \\
\hline$R^{d}$ & 1.0089 & 0.0023 & 0.0000 \\
\hline$R^{b}$ & 1.0099 & 0.0024 & 0.0000 \\
\hline$R^{k}$ & 1.0299 & 0.0006 & 0.0000 \\
\hline$R^{l(x)}$ & 1.0454 & 0.0035 & 0.0000 \\
\hline$Z^{f a m}$ & -10.0522 & 0.7034 & 0.4948 \\
\hline$Z^{f i r}$ & 2.2259 & 0.0201 & 0.0004 \\
\hline$Z^{e m p}$ & 1.0576 & 0.0035 & 0.0000 \\
\hline$\Sigma$ & 1.0245 & 0.0034 & 0.0000 \\
\hline$\Lambda$ & 1.0162 & 0.0024 & 0.0000 \\
\hline$\lambda 2$ & 0.0112 & 0.0027 & 0.0000 \\
\hline$V^{k}$ & 1.0162 & 0.0039 & 0.0000 \\
\hline$\tau^{h}$ & 0.3000 & 0.0000 & 0.0000 \\
\hline$\tau^{\Pi^{f i r}}$ & 0.1500 & 0.0000 & 0.0000 \\
\hline$\tau^{k}$ & 0.4000 & 0.0000 & 0.0000 \\
\hline$\tau^{\Pi^{b a n}}$ & 0.1500 & 0.0000 & 0.0000 \\
\hline$z$ & $\begin{array}{r}1.0000 \\
\text { (continua) }\end{array}$ & 0.0080 & 0.0001 \\
\hline
\end{tabular}


Tabela B.2: (continuação)

\begin{tabular}{|c|c|c|c|}
\hline Variável & Média & Desvio-padrão & Variância \\
\hline$z_{\mathcal{T}}$ & 1.0000 & 0.0080 & 0.0001 \\
\hline$z^{\mathcal{P}}$ & 1.0000 & 0.0062 & 0.0000 \\
\hline Charter Value & 0.0000 & 0.1326 & 0.0176 \\
\hline Lucro Banco/ L & 0.0000 & 0.0383 & 0.0015 \\
\hline Lucro Firma/ Y & 0.1207 & 0.0103 & 0.0001 \\
\hline Alavancagem & 0.6149 & 0.0323 & 0.0010 \\
\hline Exposição (1) & 0.9192 & 0.0191 & 0.0004 \\
\hline Exposição (2) & 11.3735 & 2.9423 & 8.6573 \\
\hline Spread Captação & 1.0009 & 0.0002 & 0.0000 \\
\hline Spread Oferta & 1.0145 & 0.0026 & 0.0000 \\
\hline Spread Total & 1.0155 & 0.0027 & 0.0000 \\
\hline Mark-up Médio & 1.0066 & 0.0361 & 0.0013 \\
\hline Lastro & 0.1430 & 0.0296 & 0.0009 \\
\hline Utilidade Esperada & -178.2430 & 0.1395 & 0.0195 \\
\hline
\end{tabular}

$($ HP filter, lambda $=1600)$

\section{B.4 Decomposição da Variância}

Tabela B.3: Decomposição da Variância dos Choques (em \%), após 30 períodos

\begin{tabular}{lrrrrrrrrr}
\hline Variável & $e_{z}$ & $e_{\mathcal{T}}$ & $e_{\mathcal{P}}$ & $e$ & $e_{G}$ & $e_{T}$ & $e_{\theta^{J}}$ & $e_{\theta^{E}}$ & $e_{\theta^{I}}$ \\
\hline$C$ & 58.47 & 0.00 & 0.00 & 13.80 & 16.55 & 0.20 & 2.14 & 0.00 & 8.85 \\
$H$ & 54.43 & 0.00 & 0.00 & 4.22 & 36.97 & 0.25 & 2.67 & 0.00 & 1.46 \\
(continua) & & & & & & & & & \\
\hline
\end{tabular}


Tabela B.3: (continuação)

\begin{tabular}{|c|c|c|c|c|c|c|c|c|c|}
\hline Variável & $e_{z}$ & $e_{\mathcal{T}}$ & $e_{\mathcal{P}}$ & $e$ & $e_{G}$ & $e_{T}$ & $e_{\theta^{J}}$ & $e_{\theta^{E}}$ & $e_{\theta^{I}}$ \\
\hline$M^{\text {fam }}$ & 54.74 & 0.00 & 0.00 & 27.65 & 10.82 & 0.08 & 0.88 & 0.00 & 5.82 \\
\hline$M^{b a n}$ & 20.68 & 0.29 & 0.20 & 33.70 & 23.74 & 1.25 & 13.41 & 0.00 & 6.75 \\
\hline$M$ & 58.05 & 0.02 & 0.02 & 13.29 & 17.12 & 0.30 & 3.26 & 0.00 & 7.94 \\
\hline$B^{f a m}$ & 51.39 & 0.21 & 0.00 & 14.41 & 20.21 & 0.68 & 4.87 & 0.00 & 8.22 \\
\hline$B^{b a n}$ & 29.02 & 2.91 & 0.25 & 24.94 & 23.09 & 1.06 & 11.41 & 0.00 & 7.33 \\
\hline$B$ & 52.07 & 0.02 & 0.02 & 20.21 & 16.71 & 0.51 & 3.14 & 0.00 & 7.31 \\
\hline$D$ & 21.82 & 0.29 & 0.01 & 31.22 & 24.57 & 1.28 & 13.75 & 0.00 & 7.07 \\
\hline$\tilde{C}$ & 52.96 & 0.00 & 0.00 & 23.20 & 14.53 & 0.16 & 1.68 & 0.00 & 7.47 \\
\hline$Y$ & 25.68 & 0.00 & 0.00 & 4.37 & 62.86 & 0.38 & 4.11 & 0.00 & 2.60 \\
\hline$W$ & 28.26 & 0.00 & 0.00 & 57.25 & 2.43 & 0.03 & 0.37 & 0.00 & 11.65 \\
\hline$\pi$ & 31.16 & 0.00 & 0.00 & 59.20 & 6.17 & 0.04 & 0.42 & 0.00 & 3.01 \\
\hline$x^{1}$ & 47.48 & 0.00 & 0.00 & 42.62 & 5.54 & 0.03 & 0.33 & 0.00 & 3.99 \\
\hline$x^{2}$ & 47.48 & 0.00 & 0.00 & 42.62 & 5.54 & 0.03 & 0.33 & 0.00 & 3.99 \\
\hline$\Omega$ & 49.01 & 0.00 & 0.00 & 35.86 & 10.16 & 0.05 & 0.55 & 0.00 & 4.36 \\
\hline$\tilde{p}$ & 31.16 & 0.00 & 0.00 & 59.20 & 6.17 & 0.04 & 0.42 & 0.00 & 3.01 \\
\hline$s$ & 27.45 & 0.00 & 0.00 & 63.99 & 5.45 & 0.04 & 0.38 & 0.00 & 2.69 \\
\hline$\Pi^{f i r}$ & 55.17 & 0.00 & 0.00 & 33.81 & 6.31 & 0.03 & 0.35 & 0.00 & 4.33 \\
\hline$\tilde{Y}$ & 19.58 & 0.00 & 0.00 & 9.19 & 64.11 & 0.39 & 4.18 & 0.00 & 2.55 \\
\hline$\psi$ & 16.22 & 0.08 & 0.08 & 14.79 & 21.58 & 0.93 & 33.34 & 0.09 & 12.88 \\
\hline$Q$ & 21.58 & 0.00 & 0.01 & 22.34 & 28.90 & 1.73 & 18.64 & 0.00 & 6.79 \\
\hline$J$ & 33.42 & 0.00 & 0.00 & 28.02 & 31.48 & 0.21 & 2.29 & 0.00 & 4.57 \\
\hline$K$ & 5.19 & 0.00 & 0.02 & 25.22 & 43.80 & 1.72 & 18.50 & 0.00 & 5.55 \\
\hline (continua) & & & & & & & & & \\
\hline
\end{tabular}


Tabela B.3: (continuação)

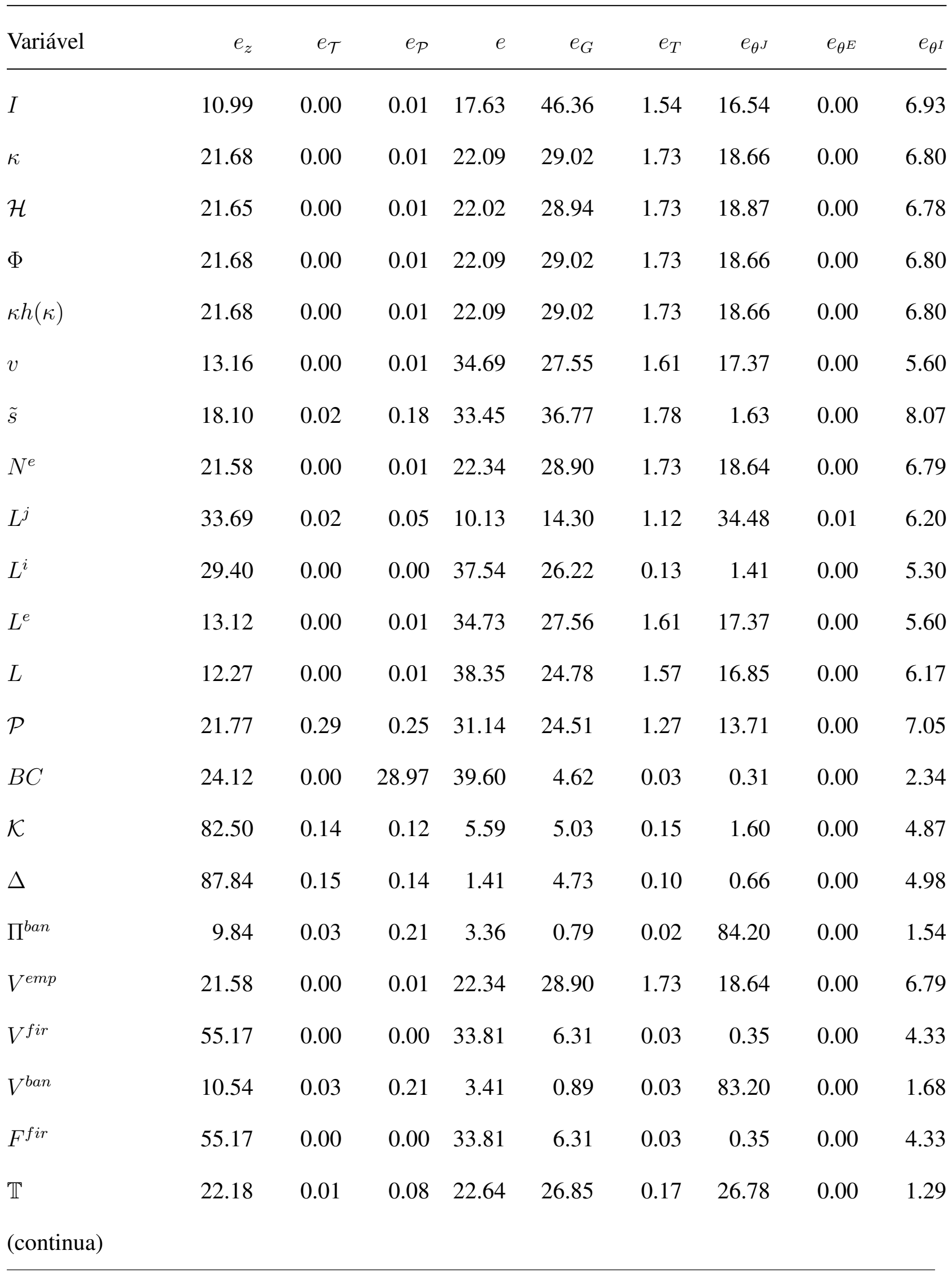


Tabela B.3: (continuação)

\begin{tabular}{|c|c|c|c|c|c|c|c|c|c|}
\hline Variável & $e_{z}$ & $e_{\mathcal{T}}$ & $e_{\mathcal{P}}$ & $e$ & $e_{G}$ & $e_{T}$ & $e_{\theta^{J}}$ & $e_{\theta^{E}}$ & $e_{\theta^{I}}$ \\
\hline$G$ & 0.00 & 0.00 & 0.00 & 0.00 & 100.00 & 0.00 & 0.00 & 0.00 & 0.00 \\
\hline$T$ & 0.00 & 0.00 & 0.00 & 0.00 & 0.00 & 100.00 & 0.00 & 0.00 & 0.00 \\
\hline déficit & 19.17 & 0.01 & 0.07 & 19.57 & 29.86 & 7.05 & 23.15 & 0.00 & 1.11 \\
\hline$\theta^{E}$ & 0.00 & 0.00 & 0.00 & 0.00 & 0.00 & 0.00 & 0.00 & 100.00 & 0.00 \\
\hline$\theta^{I}$ & 0.00 & 0.00 & 0.00 & 0.00 & 0.00 & 0.00 & 0.00 & 0.00 & 100.00 \\
\hline$\theta^{J}$ & 0.00 & 0.00 & 0.00 & 0.00 & 0.00 & 0.00 & 100.00 & 0.00 & 0.00 \\
\hline $\bar{C}$ & 48.87 & 0.10 & 0.03 & 36.58 & 7.89 & 1.17 & 4.43 & 0.17 & 0.77 \\
\hline$R^{B C}$ & $\mathrm{NaN}$ & $\mathrm{NaN}$ & $\mathrm{NaN}$ & $\mathrm{NaN}$ & $\mathrm{NaN}$ & $\mathrm{NaN}$ & $\mathrm{NaN}$ & $\mathrm{NaN}$ & $\mathrm{NaN}$ \\
\hline$R$ & 19.87 & 0.00 & 0.00 & 72.62 & 5.06 & 0.03 & 0.35 & 0.00 & 2.07 \\
\hline$R^{d}$ & 19.17 & 0.00 & 0.00 & 74.70 & 4.17 & 0.01 & 0.16 & 0.00 & 1.80 \\
\hline$R^{b}$ & 19.87 & 0.00 & 0.00 & 72.62 & 5.06 & 0.03 & 0.35 & 0.00 & 2.07 \\
\hline$R^{k}$ & 33.42 & 0.00 & 0.00 & 28.02 & 31.48 & 0.21 & 2.29 & 0.00 & 4.57 \\
\hline$R^{l(x)}$ & 65.40 & 0.04 & 0.02 & 6.00 & 17.68 & 0.24 & 2.56 & 0.00 & 8.05 \\
\hline$Z^{\text {fam }}$ & 0.15 & 0.00 & 0.00 & 0.01 & 0.04 & 0.00 & 99.78 & 0.00 & 0.02 \\
\hline$Z^{f i r}$ & 8.78 & 0.01 & 0.00 & 0.81 & 2.37 & 0.03 & 0.34 & 0.00 & 87.66 \\
\hline$Z^{e m p}$ & 65.13 & 0.04 & 0.02 & 5.98 & 17.61 & 0.24 & 2.55 & 0.41 & 8.01 \\
\hline$\Sigma$ & 65.40 & 0.04 & 0.02 & 6.00 & 17.68 & 0.24 & 2.56 & 0.00 & 8.05 \\
\hline$\Lambda$ & 19.87 & 0.00 & 0.00 & 72.62 & 5.06 & 0.03 & 0.35 & 0.00 & 2.07 \\
\hline$\lambda 2$ & 50.45 & 0.07 & 0.04 & 29.43 & 12.11 & 0.16 & 1.73 & 0.00 & 6.01 \\
\hline$V^{k}$ & 39.88 & 0.05 & 0.04 & 52.93 & 4.02 & 0.03 & 0.31 & 0.00 & 2.74 \\
\hline$\tau^{h}$ & 8.01 & 0.06 & 0.04 & 8.49 & 10.43 & 0.58 & 65.73 & 0.95 & 5.70 \\
\hline$\tau^{\Pi^{f i r}}$ & 4.00 & 0.11 & 0.03 & 13.35 & 10.35 & 0.77 & 69.33 & 1.03 & 1.01 \\
\hline (continua) & & & & & & & & & \\
\hline
\end{tabular}


Tabela B.3: (continuação)

\begin{tabular}{|c|c|c|c|c|c|c|c|c|c|}
\hline Variável & $e_{z}$ & $e_{\mathcal{T}}$ & $e_{\mathcal{P}}$ & $e$ & $e_{G}$ & $e_{T}$ & $e_{\theta^{J}}$ & $e_{\theta^{E}}$ & $e_{\theta^{I}}$ \\
\hline$\tau^{k}$ & 37.79 & 0.29 & 0.02 & 12.63 & 21.78 & 0.67 & 9.97 & 1.45 & 15.40 \\
\hline$\tau^{\Pi^{b a n}}$ & 16.35 & 0.00 & 0.01 & 13.36 & 16.20 & 1.14 & 48.63 & 0.07 & 4.23 \\
\hline$z$ & 100.00 & 0.00 & 0.00 & 0.00 & 0.00 & 0.00 & 0.00 & 0.00 & 0.00 \\
\hline$z_{\mathcal{T}}$ & 0.00 & 100.00 & 0.00 & 0.00 & 0.00 & 0.00 & 0.00 & 0.00 & 0.00 \\
\hline$z^{\mathcal{P}}$ & 0.00 & 0.00 & 100.00 & 0.00 & 0.00 & 0.00 & 0.00 & 0.00 & 0.00 \\
\hline Charter Value & 0.22 & 0.00 & 0.00 & 0.33 & 0.69 & 0.01 & 97.16 & 0.00 & 1.58 \\
\hline Lucro Banco/ L & 9.84 & 0.03 & 0.21 & 3.36 & 0.79 & 0.02 & 84.20 & 0.00 & 1.54 \\
\hline Lucro Firma/ Y & 51.69 & 0.00 & 0.00 & 33.74 & 9.60 & 0.05 & 0.52 & 0.00 & 4.40 \\
\hline Alavancagem & 56.76 & 3.10 & 0.03 & 10.69 & 16.99 & 0.41 & 4.47 & 0.00 & 7.54 \\
\hline Exposiçãa (1) & 59.01 & 0.09 & 0.53 & 8.35 & 18.58 & 0.45 & 4.89 & 0.00 & 8.09 \\
\hline Exposição (2) & 58.52 & 0.09 & 0.04 & 11.02 & 17.52 & 0.43 & 4.60 & 0.00 & 7.78 \\
\hline Spread Captação & 19.53 & 0.34 & 0.01 & 31.83 & 25.02 & 1.40 & 15.02 & 0.00 & 6.86 \\
\hline Spread Oferta & 51.09 & 0.07 & 0.04 & 25.91 & 13.71 & 0.23 & 2.43 & 0.00 & 6.53 \\
\hline Spread Total & 51.50 & 0.05 & 0.03 & 23.06 & 15.06 & 0.28 & 3.06 & 0.00 & 6.95 \\
\hline Mark-up Médio & 1.98 & 0.00 & 0.00 & 4.53 & 1.11 & 0.00 & 90.31 & 0.00 & 2.06 \\
\hline Lastro & 58.54 & 0.06 & 0.04 & 11.03 & 17.53 & 0.43 & 4.61 & 0.00 & 7.78 \\
\hline Utilidade Esp & 11.75 & 0.00 & 0.02 & 41.38 & 21.70 & 2.02 & 21.69 & 0.00 & 1.44 \\
\hline
\end{tabular}

$($ HP filter, lambda $=1600)$

\section{B.5 Autocorrelações}


Tabela B.4: Coeficientes de Autocorrelação

\begin{tabular}{|c|c|c|c|c|c|}
\hline Variável & +1 & +2 & +3 & +4 & +5 \\
\hline$C$ & 0.8970 & 0.6963 & 0.4647 & 0.2410 & 0.0458 \\
\hline$H$ & 0.4794 & 0.2329 & 0.0554 & -0.0635 & -0.1352 \\
\hline$M^{f a m}$ & 0.5476 & 0.2382 & 0.0343 & -0.0904 & -0.1592 \\
\hline$M^{b a n}$ & 0.7411 & 0.4784 & 0.2652 & 0.0970 & -0.0313 \\
\hline$M$ & 0.5831 & 0.2826 & 0.0768 & -0.0552 & -0.1344 \\
\hline$B^{f a m}$ & 0.6276 & 0.3369 & 0.1329 & -0.0036 & -0.0922 \\
\hline$B^{b a n}$ & 0.7413 & 0.4655 & 0.2476 & 0.0798 & -0.0457 \\
\hline$B$ & 0.5795 & 0.2889 & 0.0922 & -0.0337 & -0.1102 \\
\hline$D$ & 0.7425 & 0.4806 & 0.2675 & 0.0993 & -0.0293 \\
\hline$\tilde{C}$ & 0.6740 & 0.4061 & 0.1950 & 0.0354 & -0.0799 \\
\hline$Y$ & 0.5420 & 0.3298 & 0.1522 & 0.0190 & -0.0765 \\
\hline$W$ & 0.6639 & 0.4204 & 0.2133 & 0.0490 & -0.0733 \\
\hline$\pi$ & 0.4895 & 0.1915 & 0.0001 & -0.1141 & -0.1726 \\
\hline$x^{1}$ & 0.4948 & 0.2100 & 0.0224 & -0.0956 & -0.1607 \\
\hline$x^{2}$ & 0.4948 & 0.2100 & 0.0224 & -0.0956 & -0.1607 \\
\hline$\Omega$ & 0.4384 & 0.1854 & 0.0176 & -0.0914 & -0.1524 \\
\hline$\tilde{p}$ & 0.4895 & 0.1915 & 0.0001 & -0.1141 & -0.1726 \\
\hline$s$ & 0.8200 & 0.5316 & 0.2440 & 0.0064 & -0.1654 \\
\hline$\Pi^{f i r}$ & 0.7081 & 0.3036 & 0.0527 & -0.1075 & -0.1981 \\
\hline$\tilde{Y}$ & 0.5408 & 0.3316 & 0.1485 & 0.0102 & -0.0880 \\
\hline$Q$ & -0.0896 & -0.0656 & -0.0645 & -0.0587 & -0.0525 \\
\hline$J$ & 0.4505 & 0.1963 & 0.0307 & -0.0832 & -0.1499 \\
\hline
\end{tabular}


Tabela B.4: (continuação)

\begin{tabular}{|c|c|c|c|c|c|}
\hline Variável & +1 & +2 & +3 & +4 & +5 \\
\hline$K$ & 0.8160 & 0.7063 & 0.5712 & 0.4303 & 0.2917 \\
\hline$I$ & 0.4647 & 0.3263 & 0.1829 & 0.0678 & -0.0209 \\
\hline$\kappa$ & -0.0903 & -0.0647 & -0.0642 & -0.0586 & -0.0525 \\
\hline$v$ & 0.7080 & 0.4768 & 0.2812 & 0.1216 & -0.0046 \\
\hline$N^{e}$ & -0.0894 & -0.0655 & -0.0645 & -0.0587 & -0.0525 \\
\hline$L^{i}$ & 0.4555 & 0.2354 & 0.0643 & -0.0566 & -0.1323 \\
\hline$L^{e}$ & 0.7075 & 0.4765 & 0.2810 & 0.1216 & -0.0046 \\
\hline$L$ & 0.7192 & 0.4874 & 0.2895 & 0.1266 & -0.0029 \\
\hline $\mathcal{P}$ & 0.7424 & 0.4803 & 0.2673 & 0.0991 & -0.0295 \\
\hline$B C$ & -0.0742 & -0.0709 & -0.0661 & -0.0604 & -0.0541 \\
\hline $\mathcal{K}$ & 0.6640 & 0.3914 & 0.1768 & 0.0161 & -0.0977 \\
\hline$\Delta$ & -0.0920 & -0.0873 & -0.0807 & -0.0697 & -0.0573 \\
\hline$\Pi^{b a n}$ & 0.6306 & 0.3833 & 0.2050 & 0.0633 & -0.0452 \\
\hline$V^{e m p}$ & -0.0894 & -0.0655 & -0.0644 & -0.0587 & -0.0525 \\
\hline$V^{f i r}$ & 0.7081 & 0.3036 & 0.0527 & -0.1075 & -0.1981 \\
\hline$V^{b a n}$ & 0.6269 & 0.3793 & 0.2022 & 0.0617 & -0.0459 \\
\hline$F^{f i r}$ & 0.7081 & 0.3036 & 0.0527 & -0.1075 & -0.1981 \\
\hline $\mathbb{T}$ & 0.3520 & 0.2898 & 0.1354 & 0.0150 & -0.0722 \\
\hline$G$ & 0.6748 & 0.4124 & 0.2055 & 0.0468 & -0.0704 \\
\hline$T$ & 0.6124 & 0.3250 & 0.1170 & -0.0284 & -0.1249 \\
\hline déficit & 0.4905 & 0.3755 & 0.2134 & 0.0744 & -0.0365 \\
\hline$\theta^{E}$ & 0.6919 & 0.4380 & 0.2335 & 0.0730 & -0.0488 \\
\hline (continua) & & & & & \\
\hline
\end{tabular}


Tabela B.4: (continuação)

\begin{tabular}{|c|c|c|c|c|c|}
\hline Variável & +1 & +2 & +3 & +4 & +5 \\
\hline$\theta^{I}$ & 0.6919 & 0.4380 & 0.2335 & 0.0730 & -0.0488 \\
\hline$\theta^{J}$ & 0.6919 & 0.4380 & 0.2335 & 0.0730 & -0.0488 \\
\hline$R$ & 0.6059 & 0.3080 & 0.0949 & -0.0489 & -0.1391 \\
\hline$R^{d}$ & 0.5971 & 0.2990 & 0.0868 & -0.0552 & -0.1431 \\
\hline$R^{b}$ & 0.6059 & 0.3080 & 0.0949 & -0.0489 & -0.1391 \\
\hline$R^{k}$ & 0.4505 & 0.1963 & 0.0307 & -0.0832 & -0.1499 \\
\hline$R^{l(x)}$ & 0.6042 & 0.3439 & 0.1465 & 0.0037 & -0.0948 \\
\hline$Z^{f a m}$ & 0.6917 & 0.4378 & 0.2332 & 0.0727 & -0.0490 \\
\hline$Z^{f i r}$ & 0.6749 & 0.4199 & 0.2165 & 0.0593 & -0.0580 \\
\hline$Z^{e m p}$ & 0.6045 & 0.3443 & 0.1468 & 0.0040 & -0.0946 \\
\hline$\Sigma$ & 0.6042 & 0.3439 & 0.1465 & 0.0037 & -0.0948 \\
\hline$\Lambda$ & 0.6059 & 0.3080 & 0.0949 & -0.0489 & -0.1391 \\
\hline$\lambda 2$ & 0.4924 & 0.2032 & 0.0155 & -0.0957 & -0.1544 \\
\hline$V^{k}$ & 0.3933 & 0.1511 & -0.0039 & -0.0954 & -0.1426 \\
\hline$z$ & 0.6658 & 0.3992 & 0.1914 & 0.0341 & -0.0805 \\
\hline$z_{\mathcal{T}}$ & 0.6658 & 0.3992 & 0.1914 & 0.0341 & -0.0805 \\
\hline$z^{\mathcal{P}}$ & 0.6621 & 0.3939 & 0.1858 & 0.0291 & -0.0844 \\
\hline Charter Value & 0.7419 & 0.4760 & 0.2582 & 0.0864 & -0.0446 \\
\hline Lucro Banco/ L & 0.6306 & 0.3833 & 0.2050 & 0.0633 & -0.0452 \\
\hline Lucro Firma/ Y & 0.6983 & 0.2947 & 0.0444 & -0.1141 & -0.2025 \\
\hline Alavancagem & 0.7480 & 0.4365 & 0.2001 & 0.0269 & -0.0948 \\
\hline Exposição (1) & 0.7720 & 0.4553 & 0.2120 & 0.0324 & -0.0945 \\
\hline (continua) & & & & & \\
\hline
\end{tabular}


Tabela B.4: (continuação)

\begin{tabular}{lrrrrr}
\hline Variável & +1 & +2 & +3 & +4 & +5 \\
\hline Exposição (2) & 0.7525 & 0.4389 & 0.2011 & 0.0269 & -0.0953 \\
Spread Captação & 0.7464 & 0.4871 & 0.2750 & 0.1065 & -0.0234 \\
Spread Oferta & 0.4951 & 0.2102 & 0.0238 & -0.0877 & -0.1478 \\
Spread Total & 0.5037 & 0.2206 & 0.0336 & -0.0796 & -0.1422 \\
Mark-up Médio & 0.6822 & 0.4322 & 0.2291 & 0.0694 & -0.0514 \\
Lastro & 0.7530 & 0.4393 & 0.2012 & 0.0270 & -0.0953 \\
Utilidade Esperada & 0.7632 & 0.5470 & 0.3548 & 0.1906 & 0.0549 \\
\hline
\end{tabular}

$($ HP filter, lambda $=1600)$ 


\section{Apêndice C}

\section{EXTENSÕES DO MODELO BÁSICO}

Este apêndice contém os ajustes ao modelo básico produzidos pelas intervenções analisadas no Capítulo 3.

\section{C.1 Depósitos Compulsórios}

\section{C.1.1 Problema do Banco sob Compulsório em Moeda}

Tomando o problema do banco A.6, a restrição (3.2) altera apenas as condições de ótimo para a moeda e os depósitos bancários, obviamente:

$$
\begin{aligned}
\Lambda E \frac{1}{\pi^{\prime}}+E \frac{1}{\pi^{\prime}} \lambda_{3}^{\prime}+\Lambda \lambda_{4} & =\lambda_{1} \\
\Lambda\left(R^{d}+\mathcal{C}_{d}\right)+E \lambda_{3}^{\prime} \mathcal{P}^{\prime}{ }_{d}+\Lambda \lambda_{4} \varrho_{M} & =\lambda_{1}+\lambda_{2} z_{\mathcal{T}} \mathcal{T}_{d}
\end{aligned}
$$

A interpretação garante que ou $\lambda_{3}^{\prime}$ ou $\lambda_{4}$ é nulo, mas pelo menos um é positivo, indicando qual mecanismo determina a moeda do banco:

$$
\left(E \frac{1}{\pi^{\prime}} \frac{\lambda_{3}^{\prime}}{\Lambda}+\lambda_{4}\right)=R-E \frac{1}{\pi^{\prime}}
$$


Por sua vez a demanda de depósitos bancários será dada por:

$$
R^{d}+\mathcal{C}_{d}+\underbrace{\left((1-a) \mathcal{P}^{\prime}{ }_{d}+a \varrho_{M}\right)\left(R-E \frac{1}{\pi^{\prime}}\right)}_{\text {custo de oportunidade marginal da moeda }}=R+\frac{\lambda_{2}}{\Lambda} z_{\mathcal{T}} \mathcal{T}_{d}
$$

com $a=1$, se $\lambda_{4}>0$ e $a=0$ caso contrário.

\section{C.1.2 Problema do Banco sob Compulsório em Títulos}

Retornando ao problema do banco A.6 para impor a restrição (3.4). As condições de ótimo para a títulos e depósitos bancários são, respectivamente:

$$
\begin{aligned}
R^{b}+\lambda_{5} & =R \\
R^{d}+\mathcal{C}_{d}+\left((1-a) \mathcal{P}^{\prime}{ }_{d}+a \varrho_{M}\right)\left(R-E \frac{1}{\pi^{\prime}}\right)+\lambda_{5} \varrho_{M} & =R+\frac{\lambda_{2}}{\Lambda} z_{\mathcal{T}} \mathcal{T}_{d}
\end{aligned}
$$

Portanto, se a restrição de compulsório de títulos é ativa, $\lambda_{5}>0$, além de determinar a reserva de liquidez, a taxa de juros dos títulos públicos será diferente da taxa de juros do ativo livre de risco em equilíbrio.

\section{C.1.3 Prova da Proposição 3.1}

Proposição 3.1. A política de reservas compulsórias em títulos públicos será efetiva em equilíbrio estacionário se:

$$
\varrho_{B}>1-\frac{L-\mathcal{K}}{D}-\varrho_{M}
$$

Prova. Tome a restrição de balanço patrimonial do banco (2.36) em estado estacionário $(i=$ 
$a=b c=0)$ :

$$
L+\frac{M}{P}+B=D+\mathcal{K}
$$

Seja $\tilde{\varrho}_{M}$ o nível de moeda em relação aos depósitos bancários, que pode ser explicado pela efetividade da regulação de depósitos compulsórios ou da liquidez para pagamentos. Neste último caso é possível, todavia descrever uma alíquota implícita de reservas voluntárias sobre depósitos. $\tilde{\varrho}_{M}=\max \left(\varrho_{M}, \frac{\eta_{\mathcal{P}} \ln (D+1)}{D}\right)$. Então, colocando o balanço patrimonial em razão dos depósitos bancários:

$$
\tilde{\varrho}_{B}=1-\frac{L-\mathcal{K}}{D}-\tilde{\varrho}_{M}
$$

@ é a alíquota implícita obtida para as reservas em títulos públicos. O banco constitui esse volume de títulos públicos de maneira voluntária.

\section{C.2 Requerimentos de Capital}

\section{C.2.1 Problema do Banco sob Requerimentos de Capital}

Seja o problema do banco A.6 do modelo básico. A restrição em (3.6) modifica as condições de primeira ordem do crédito e de Benveniste-Scheinkman para o capital bancário:

$$
\lambda_{1}+\Gamma \lambda_{2}+\lambda_{6}+\Lambda \mathcal{C}_{l}=\sigma
$$

$$
\mathfrak{V}_{\mathcal{K}}=-E r^{\prime}+\lambda_{1}+\lambda_{6}+\lambda_{2} z_{\mathcal{T}}
$$

$\lambda_{6}$ é o preço-sombra da restrição prudencial, o custo marginal do capital regulado. O capital bancário fica mais valorizado, porque o capital marginal garante $1 / \Gamma$ de crédito marginal para 
o banco.

As condições de primeira ordem diretamente afetadas são o crédito e a capitalização.

$$
\Sigma=\frac{\lambda_{1}}{\Lambda}+\frac{\lambda_{2}}{\Lambda}+\Gamma \frac{\lambda_{6}}{\Lambda}+\mathcal{C}_{l}
$$

(C.10)

$$
\Lambda=E \mathfrak{V}_{\mathcal{K}^{\prime}}, \quad \Delta>0
$$

além de $\Lambda$, que é o valor econômico do lucro. $\Lambda$ aumenta menos do que $E \mathfrak{V}_{\mathcal{K}^{\prime}}$ porque o acumulação do capital não é integral, a fração $(1-\Theta)$ é transferida. A regulação impõe a alteração na substituição intertemporal entre lucros e capital bancário. O equilíbrio se dá com a redução da capitalização interna a fim de aumentar o lucro do banco e reduzir a acumulação de capital. Indiretamente as demais equações são afetadas porque o $\Lambda$ desconta os elementos do lucro futuro nas condições de ótimo. 